ORNL/TM-2017/234

Travel Patterns and Characteristics of LowIncome Subpopulation in New York State: Final Technical Memorandum for Task 14

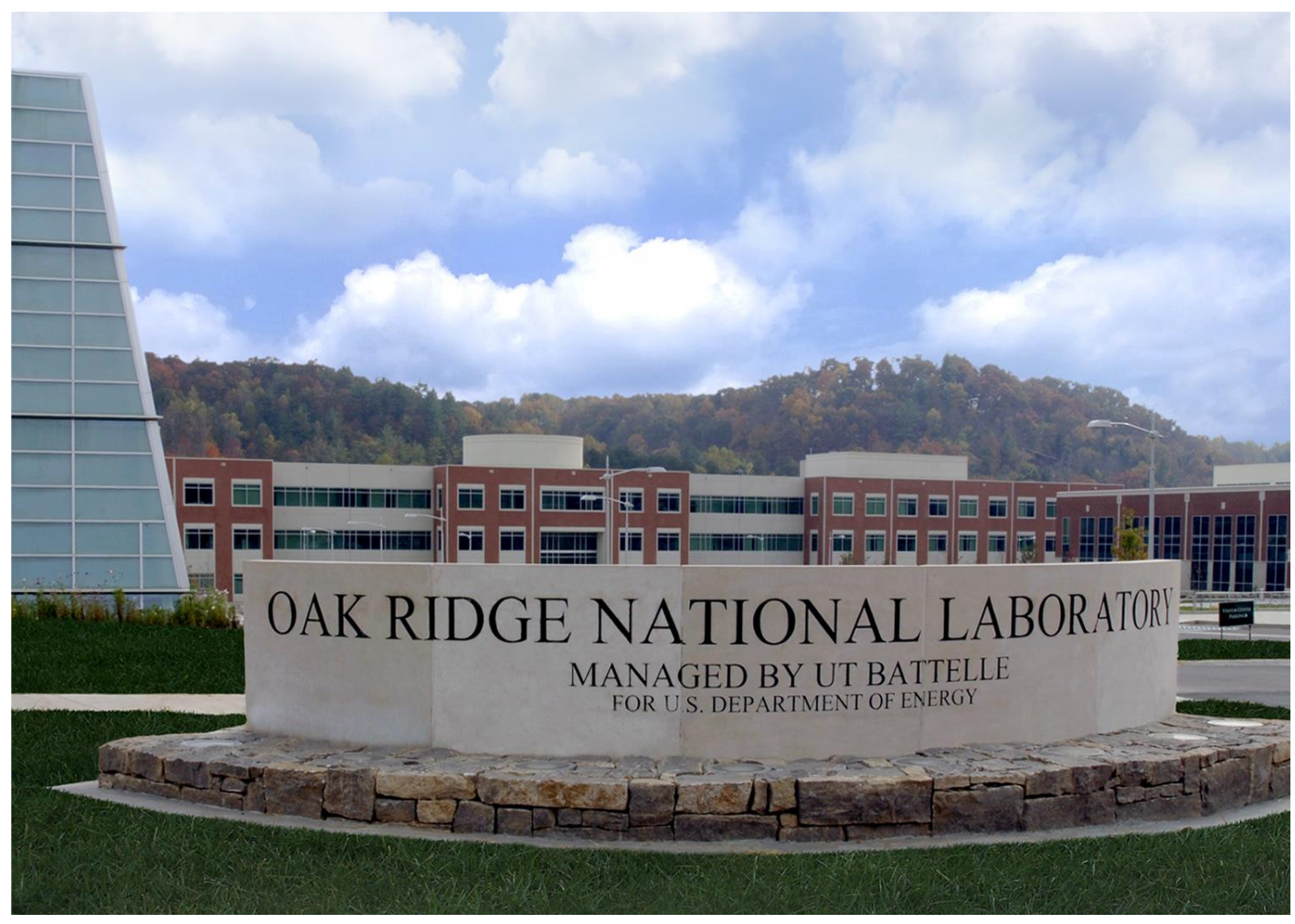

H. L. Hwang

T. Reuscher

H. Lim

September 2017

OAK RIDGE NATIONAL LABORATORY 


\section{DOCUMENT AVAILABILITY}

Reports produced after January 1, 1996, are generally available free via US Department of Energy (DOE) SciTech Connect.

Website http://www.osti.gov/scitech/

Reports produced before January 1, 1996, may be purchased by members of the public from the following source:

National Technical Information Service

5285 Port Royal Road

Springfield, VA 22161

Telephone 703-605-6000 (1-800-553-6847)

TDD 703-487-4639

Fax 703-605-6900

E-mail info@ntis.gov

Website http://www.ntis.gov/help/ordermethods.aspx

Reports are available to DOE employees, DOE contractors, Energy Technology Data Exchange representatives, and International Nuclear Information System representatives from the following source:

Office of Scientific and Technical Information

PO Box 62

Oak Ridge, TN 37831

Telephone 865-576-8401

Fax 865-576-5728

E-mail reports@osti.gov

Website http://www.osti.gov/contact.html

This report was prepared as an account of work sponsored by an agency of the United States Government. Neither the United States Government nor any agency thereof, nor any of their employees, makes any warranty, express or implied, or assumes any legal liability or responsibility for the accuracy, completeness, or usefulness of any information, apparatus, product, or process disclosed, or represents that its use would not infringe privately owned rights. Reference herein to any specific commercial product, process, or service by trade name, trademark, manufacturer, or otherwise, does not necessarily constitute or imply its endorsement, recommendation, or favoring by the United States Government or any agency thereof. The views and opinions of authors expressed herein do not necessarily state or reflect those of the United States Government or any agency thereof. 
Engineering and Transportation Science Division

Final Technical Memorandum for Task 14

\title{
TRAVEL PATTERNS AND CHARACTERISTICS OF LOW-INCOME SUBPOPULATION IN NEW YORK STATE
}

\author{
Prepared by \\ Ho-Ling Hwang, Ph.D. \\ Tim Reuscher \\ H. Lim, Ph.D.
}

Date: October 26, 2017

\author{
Prepared by \\ OAK RIDGE NATIONAL LABORATORY \\ Oak Ridge, Tennessee 37831-6283 \\ Managed by \\ UT-BATTELLE, LLC \\ for the \\ US DEPARTMENT OF ENERGY \\ under contract DE-AC05-00OR22725
}





\section{CONTENTS}

\begin{tabular}{|c|c|c|}
\hline \multicolumn{3}{|c|}{ LIST OF FIGURES } \\
\hline \multicolumn{3}{|c|}{ LIST OF TABLES } \\
\hline \multicolumn{3}{|c|}{ ACRONYMS } \\
\hline \multicolumn{3}{|c|}{ ABSTRACT.... } \\
\hline \multicolumn{3}{|c|}{ 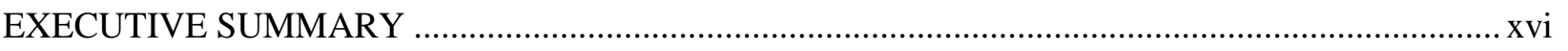 } \\
\hline \multirow{4}{*}{$\begin{array}{r}1 . \\
1 . \\
1 . \\
1 .\end{array}$} & ODUC & TION . \\
\hline & $\mathrm{BACl}$ & 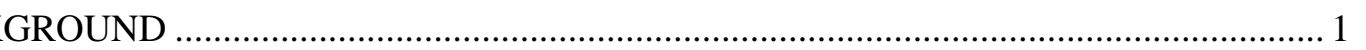 \\
\hline & PURF & OSE OF THIS STUDY... \\
\hline & ORG & NIZATION OF REPORT. \\
\hline \multirow[t]{8}{*}{2.} & F DES & CRIPTIONS OF DATA SOURCES. \\
\hline & NHTs & \\
\hline & CENS & US DATA. \\
\hline & ADD & TIONAL INFORMATION SOURCES. \\
\hline & DEFI & JITIONS OF LOW-INCOME HOUSEHOLDS .. \\
\hline & 2.4 .1 & Simple Cutoff Value or Category .. \\
\hline & 2.4 .2 & Census Bureau Poverty Threshold..... \\
\hline & 2.4 .3 & HUD Very-Low-Income ....................... \\
\hline 2.5 & COM & $\begin{array}{l}\text { ARISON OF CENSUS POVERTY THRESHOLDS AND HUD'S VERY-LOW } \\
\text { ME LIMITS }\end{array}$ \\
\hline \multirow[t]{3}{*}{2.6} & CURI & ENT STUDY and ANALYSIS FOCUS \\
\hline & 2.6.1 & Geographical Region Considerations in Data Analysis ..... \\
\hline & 2.6.2 & Scope of Population and Households... \\
\hline \multirow{16}{*}{$\begin{array}{l}3 . \\
3 . \\
3 .\end{array}$} & RACT & ERISTICS OF THE NYS LOW-INCOME POPULATION ... \\
\hline & OVEI & VIEW \\
\hline & GEOC & RAPHIC DISTRIBUTION OF LOW INCOME NYS HOUSEHOLDS..... \\
\hline & NHTs & -BASED DEMOGRAPHIC PROFILE OF NYS VERY-LOW INCOME \\
\hline & POPL & LATION . \\
\hline & 3.3.1 & Impacts of \\
\hline & 3.3 .2 & Driver Availability ... \\
\hline & 3.3 .3 & Household Size .......... \\
\hline & 3.3.4 & Vehicle Ownership............... \\
\hline & 3.3.5 & Relationship between Number of Drivers and Vehicle Ownership ............ \\
\hline & 3.3.6 & Vehicle Age ..... \\
\hline & 3.3 .7 & Worker Status. \\
\hline & 3.3 .8 & Life Cycle... \\
\hline & ZERC & 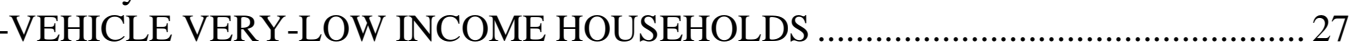 \\
\hline & 3.4.1 & Geographic Distribution of Zero-Vehicle Very-Low Income Households.............. \\
\hline & 3.4 .2 & Share of Very-Low Income among Households Owning Zero-Vehicles ... \\
\hline & ILITY & of LOW-INCOME HOUSEHOLDS \\
\hline & OVEI & VIEW OF LOW INCOME TRAVEL. \\
\hline & 4.1.1 & Impact of Income on NYS Resident's Travel.. \\
\hline & 4.1.2 & Impact of Income on Vehicle Travel ................... \\
\hline \multirow[t]{3}{*}{4.2} & TRA & EL FREQUENCIES BY PERSON TRIP ........... \\
\hline & 4.2.1 & Average Daily Person-Trip Rate..... \\
\hline & 4.2 .2 & 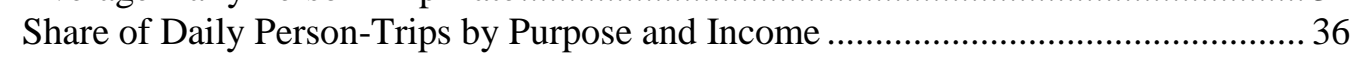 \\
\hline
\end{tabular}


4.2.3 Share of Daily Person-Trips by Mode and Income............................................... 36

4.3 MOBILITY STATISTICS RELATED TO TRIP LENGTH ........................................ 44

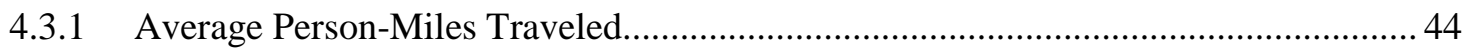

4.3.2 Distribution of PMT by Trip Purpose ........................................................................ 45

4.3.3 Impacts of Income on Average Person-Trip Length (Distance) .................................. 46

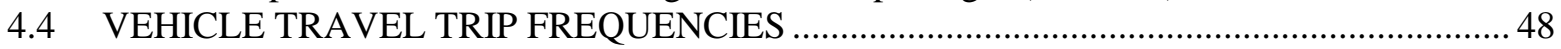

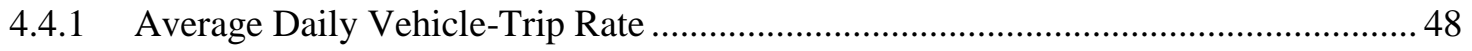

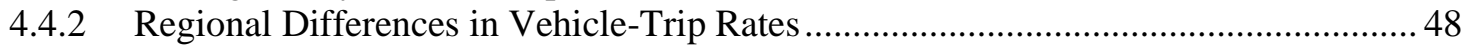

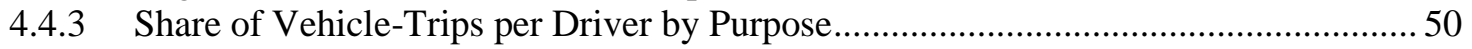

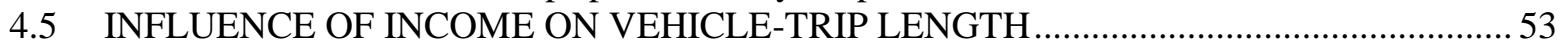

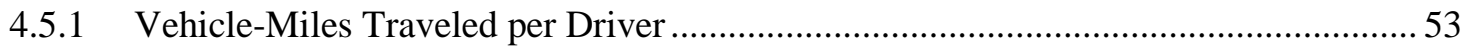

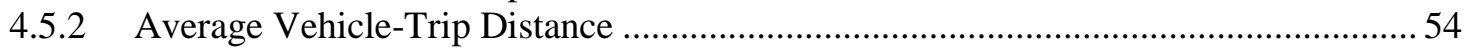

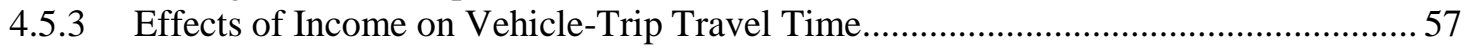

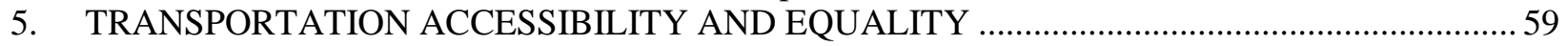

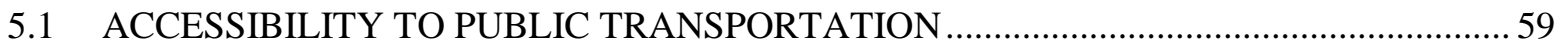

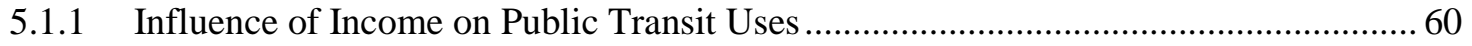

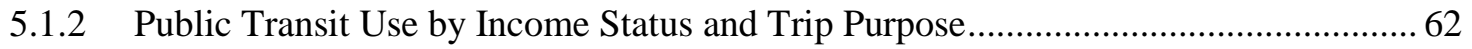

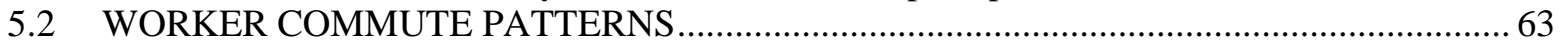

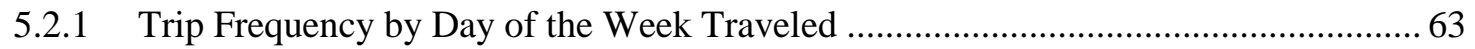

5.2.2 Length of POV Commute-Trip by Population Density .......................................... 65

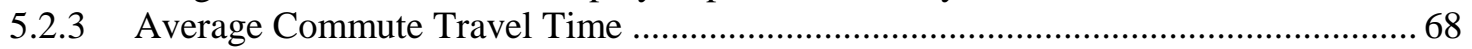

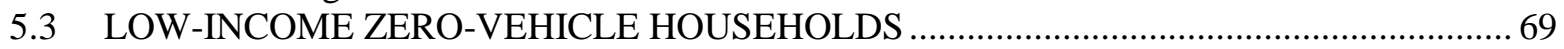

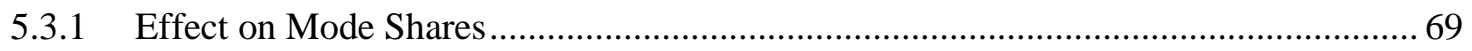

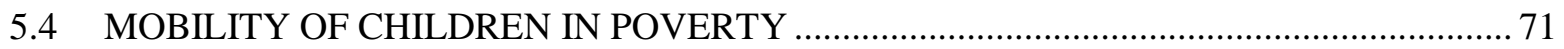

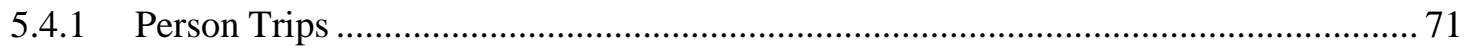

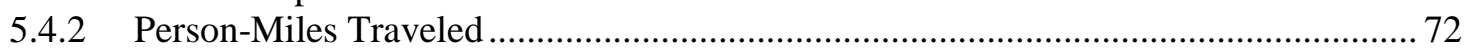

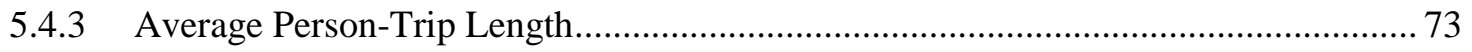

5.4.4 Mode Shares on Trips Made by Children (ages 5-15 years old) ................................ 74

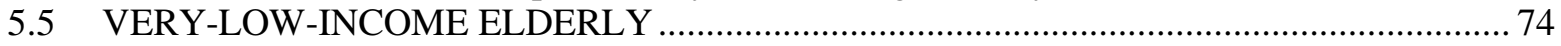

6. VIEWS OF TRANSPORTATION SERVICES BY LOW-INCOME HOUSEHOLDS ................... 79

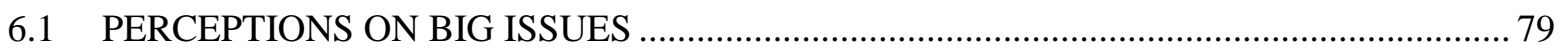

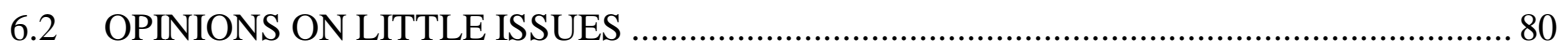

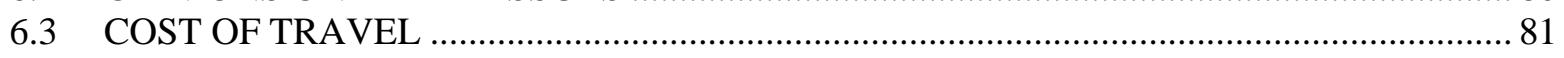

6.4 COMPARISON WITH VIEWS FROM VERY-LOW INCOMES …............................... 83

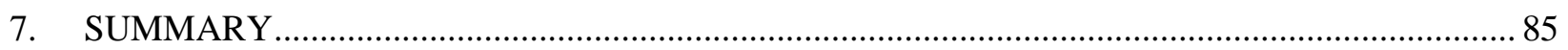

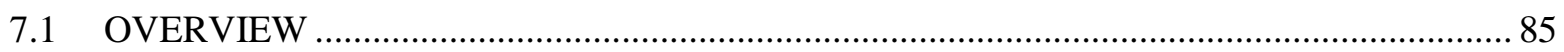

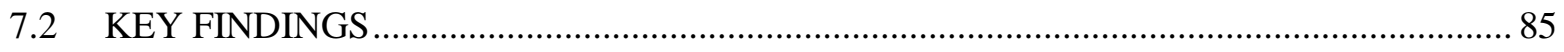

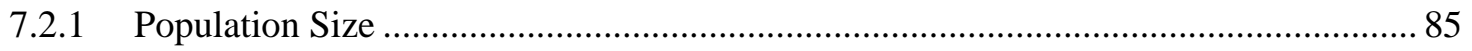

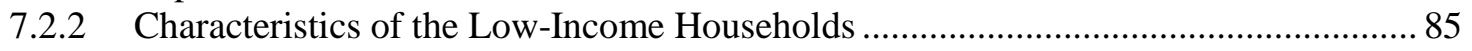

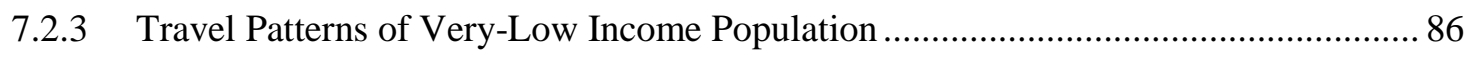

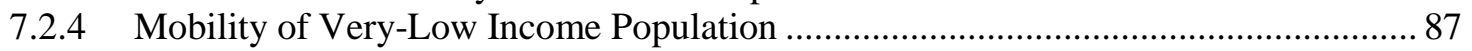

7.2.5 Accessibility \& Transportation Equality Issues ..................................................... 90

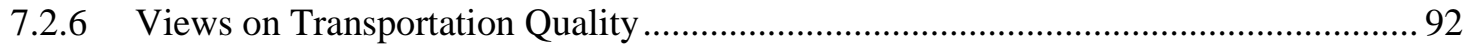

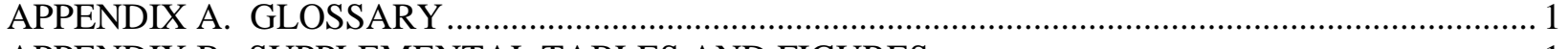

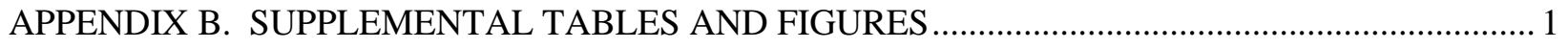




\section{LIST OF FIGURES}

Figure

Page

Figure 1-1. Median family income in NYS counties (ACS 2008-2012 data) .......................................... 2

Figure 2-2. Percent of households in HUD-defined very-low income vs. low income groups (2009

NHTS)...

Figure 3-1. Share of population age 5 year and older in very-low income households (NHTS data), ...... 12

Figure 3-2. Shares of households with very-low income status (NHTS data) ...................................... 13

Figure 3-3. Percent of population below poverty level in NYS counties (ACS 2008-2012 data) ............. 14

Figure 3-4. Population share of very-low income households by region (NHTS data) ........................... 16

Figure 3-5. Percent of population with very-low income by race and time (NHTS) .............................. 17

Figure 3-6. Likelihood of being a driver by household income category (NHTS 2009 data) .................. 18

Figure 3-7. Distribution of households by number of drivers and income status for NYS (NHTS

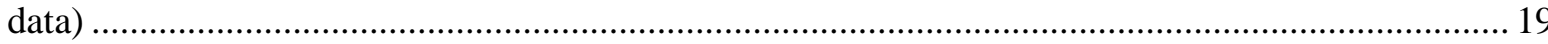

Figure 3-8. Percent of very-low income households without a driver by region (NHTS data) ................. 19

Figure 3-9. Percent of other income households (top chart) without a driver compared to very-low income households (bottom chart) by region (NHTS data) ............................................................. 20

Figure 3-10. Percent of NYS households by household size and income group ................................... 21

Figure 3-11. Distributions of NYS households by vehicle ownership and income status ........................ 22

Figure 3-12. Distribution comparison of NYS to the rest of the U.S. households by vehicle

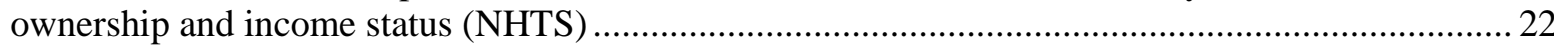

Figure 3-13. Likelihood of being a zero-vehicle household by income category and region (2009

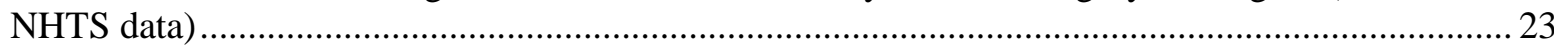

Figure 3-14. Distribution of NYS households by number of vehicle with respect to number of

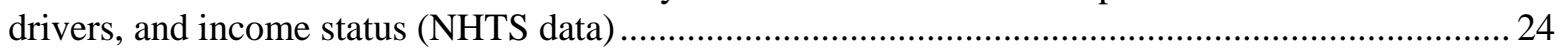

Figure 3-15. Average NYS resident's vehicle age by income status over the NHTS years .....................2 24

Figure 3-16. Percent of population employed by income status (2001 and 2009 NHTS) .......................25

Figure 3-17. Distribution of NYS households by life cycle category (NHTS) .................................... 27

Figure 3-18. Distribution of zero-vehicle very-low income households in NYS (2009 NHTS) .............. 28

Figure 3-19. Share of zero-vehicle households among very-low income households by region for

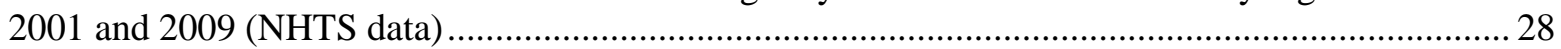

Figure 3-20. Share of very-low income households with zero-vehicles by household region (NHTS

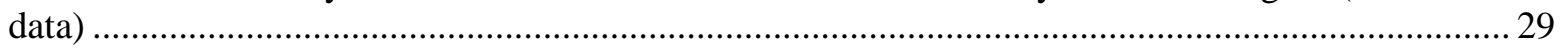

Figure 4-1. Share of very-low income population in NYS, by travel status on NHTS-assigned

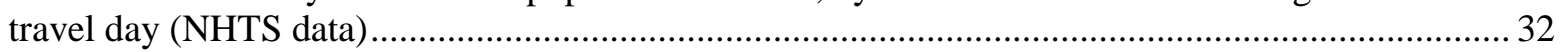

Figure 4-2. Share of very-low-income NYS residents drivers by travel status on NHTS-assigned

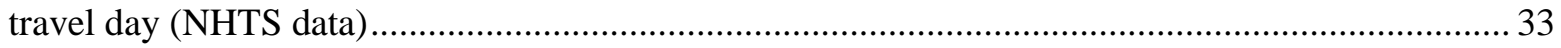

Figure 4-3. Average daily person trips by income status, region, and year (NHTS data) ....................... 35

Figure 4-4. Distribution of person trips by trip purpose and income status (NHTS data) ........................ 36

Figure 4-5. Distribution of NYS resident person trips by mode and income status (NHTS data) ............. 37

Figure 4-6. Comparison of mode shares by income status for selected areas in NYS and the Rest of

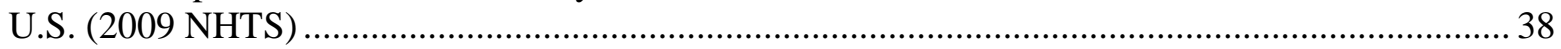

Figure 4-7. Comparison of mode shares by income status for selected areas in NYS and the Rest of

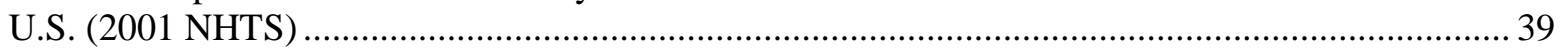

Figure 4-8. Percent of NYS's person-trips made on public transit, by purpose and income status

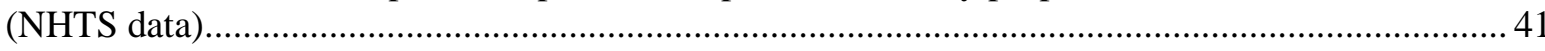

Figure 4-9. Distribution of public transit trips by purpose (2009 NHTS) .............................................. 41

Figure 4-10. Percent of NYS's walking person-trips by trip purpose and income level (NHTS data)...... 42 
Figure 4-11. Transit person-trip mode shares by urban size (in population density) and income

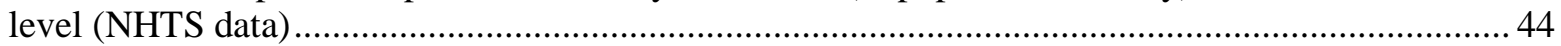

Figure 4-12. Average person-miles traveled by income status for NYS (NHTS data).......................... 45

Figure 4-13. Distribution of PMT by trip purpose and income status for NYS (NHTS data) .................. 46

Figure 4-14. Average daily person-trip length (in miles) by region and income status (2009 NHTS)...... 47

Figure 4-15. Average daily person-trip length (in miles) by region and income status (2001 NHTS)...... 47

Figure 4-16. Average vehicle-trip rates by income status for NYS households (NHTS data) ................. 48

Figure 4-17. Average number of vehicle-trips/driver by region/population-density and income status (NHTS data)

Figure 4-18. Distribution and number of average vehicle-trips for NYS drivers by trip purpose and

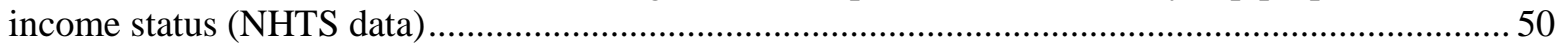

Figure 4-19. Average daily VMT (miles) by income status for drivers in NYS (NHTS data) .................53

Figure 4-20. Distribution of daily vehicle-miles traveled (VMT) by trip purpose and income status

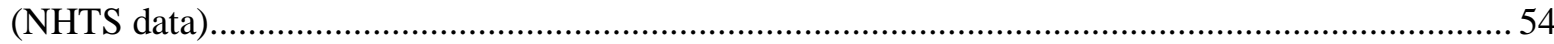

Figure 4-21. Average travel distance (miles) per vehicle-trip made by NYS drivers (NHTS data) ..........55

Figure 4-22. Average length of vehicle trips by population density/region and income status (2009,

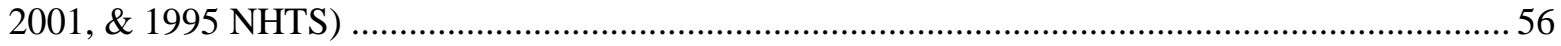

Figure 4-23. Average time spent in vehicle per NYS-driver who drove on travel day (minutes) .............57

Figure 5-1. Distribution of very-low income households and locations of public transit stops in NYS

Figure 5-2. Public transit share (all persons age 5 years and over) by income and region (2009 NHTS).

Figure 5-3. Public transit share among children (ages 5-15) by income and region (2009 NHTS).......... 61

Figure 5-4. Public transit share among elderly residents (65+) by income and region (2009 NHTS)....... 61

Figure 5-5. Distribution of daily public transit trips by trip purpose and income level in NYS (2009 $\& 2001$ NHTS)

Figure 5-6. Distribution of daily public transit trips by non-work purpose and income for NYS residents (NHTS).....

Figure 5-7. Average number of daily person-trips per worker by income status for NYS residents (2009 NHTS)

Figure 5-8. Average number of daily commute trips per worker by income status for NYS residents (2009 NHTS)

Figure 5-9. Percent of daily person trips made for work purpose by income status for NYS

Figure 5-10. Average POV commute-trip length (in miles) by income status, population density, and region in 2009

Figure 5-11. Commute travel time per worker for POV trips by income status and population density (2009 NHTS).....

Figure 5-12. Commute travel time per worker for trips made using public transit during 2009 by income status and population density (2009 NHTS)

Figure 5-13. Mode shares of person-trips for zero-vehicle households, by income status and region (2009 NHTS)

Figure 5-14. Mode shares of person-trips for very-low income with zero-vehicle households by region (2001 and 2009 NHTS)

Figure 5-15. Average daily person-trips comparison between children (age 5-15 years old) and all others in NYS by income status (NHTS data)

Figure 5-16. Comparison of average daily person-miles traveled between children (age 5-15 years old) and all others in NYS by income status (NHTS data)....

Figure 5-17. Comparison of average person-trip length between children (ages 5-15 years old) and

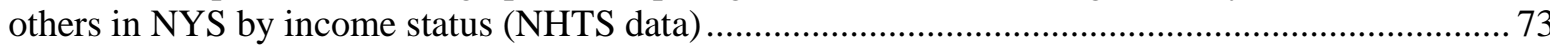

Figure 5-18. Shares of person-trips for very-low income elderly households by trip purpose, household size, and region of residency in 2009 
Figure 5-19. Mode share on person-trips made by individuals from very-low income elderly households, by household size and region (2009 NHTS)

Figure 5-20. Travel statistics for trips made by persons from very-low income elderly households by size of household and region (2009 NHTS)

Figure 5-21. Travel statistics for vehicle trips made by drivers from very-low income elderly households, by size and region (2009 NHTS) .

Figure 6-1. Big issues associated with travel concerns by NYS residents (2009 NHTS).

Figure 6-2. Big issues of travel concerns for individuals lived in the Rest of U.S. (2009 NHTS)

Figure 6-3. Travel concerns identified as big issues by individuals living in NYS (2009 NHTS)

Figure 6-4. Travel concerns identified as little issues by individuals living in the Rest of U.S. (2009 NHTS).

Figure 6-5. Share of rating on residents' view among those who expressed "price of travel" was the most important concern by income status and region (2009 NHTS).

Figure 6-6. Percent of individuals who thought price of travel was a big issue given that it was the most important issue they identified, by income and region (2009 NHTS)

Figure 6-7. Percent of very-low income residents indicating a given issue as significant concern or a big issue

Figure 7-1. Mobility statistics for trips made by a very-low-income NYS resident, in relation to each trip made by an other-income person (NHTS data)

Figure 7-2. Mobility statistics for vehicle trips made by a very-low-income NYS driver, in relation to each trip made by an other-income driver (NHTS data)

Figure B-1. Comparison of Census national poverty thresholds and HUD very-low income limits for areas in NYS (2009) 


\section{LIST OF TABLES}

Table

Page

Table 3-1. Very-low Income Households in NYS by areas (NHTS data)

Table 3-2. New York State household distribution by life-cycle category and income status in

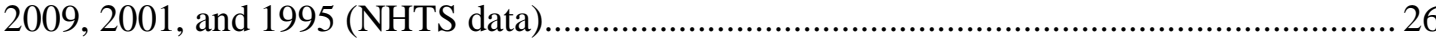

Table 4-1. Travel status for NYS residents by income status (2009, 2001, and 1995 NHTS data).......... 31

Table 4-2. Travel status for NYS drivers by income status $(2009,2001$, and 1995 NHTS data)............. 33

Table 4-3. Daily NYS resident person-trips by mode, purpose, and income status - 2009, 2001, and 1995 NHTS

Table 4-4. Daily person-trips by mode, urban size (population density), and income status - 2009, 2001, and 1995 NHTS.

Table 4-5. Average number of vehicle trips (VT) per driver by purpose, population density, and income status $(2009,2001$, and 1995 NHTS data).

Table 5-1. Commute statistics by mode, population density, and household income status in 2009 (2009 NHTS)

Table 5-2. Mobility statistics for NYS residents with/without access to vehicle (2009 NHTS) .............. 70

Table 5-3. Mobility statistics of children by mode of transportation and household income level

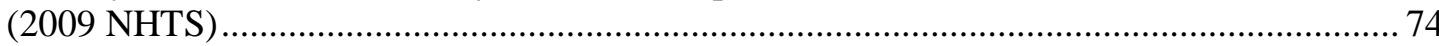

Table 5-4. Very-low income elderly households by household size and region in 2009 (NHTS data)..... 75

Table 7-1. Mobility statistics for person-trips taken by NYS residents by income status ........................ 87

Table 7-2. Mobility statistics for vehicle-trips taken by NYS residents by income status ...................... 89

Table B-1A. 2009 HUD very low income cutoffs, New York State ...................................................... 3

Table B-1B. 2001 HUD Very low income cutoffs, New York State..................................................... 5

Table B-1C. 1995 HUD very low income cutoffs, New York State......................................................... 7

Table B-2. Census poverty thresholds for 2009 by size of family and number of related children

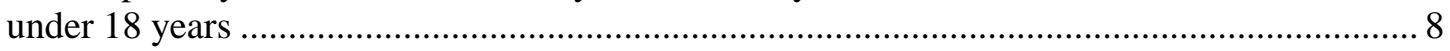

Table B-3. Example of HUD very-low income cutoff by MSA and county in NYS for 2009................. 9

Table B-4A. Persons 5+ and households by HUD low income and very low income status, 2009 NHTS

Table B-4B. Persons 5+ and households by HUD low income and very low income status, 2001

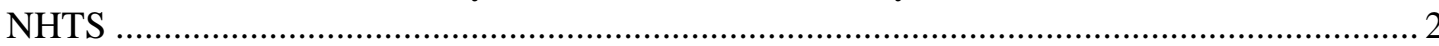

Table B-4C. Persons 5+ and households by HUD low income and very low income status, 1995

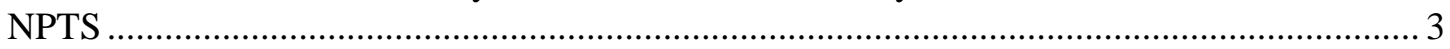

Table B-5. Daily person trips per person by region of residency ......................................................... 4

Table B-6. Daily vehicle trips per driver by region of residency ............................................................ 4

Table B-7. Daily vehicle trip length by region of residency ................................................................ 4

Table B-8. Standard errors for commute statistics by mode, income status, and population density in 2009 



\section{ACKNOWLEGEMENTS}

The authors would like to express their sincere appreciations to Mr. Angel Canales of the New York State Department of Transportation (NYSDOT) for his constant guidance and to the NYSDOT for continuous financial support that allowed the authors to conduct this study. A special thanks goes to Shelia Moore for her tireless efforts in editing and reformatting that greatly improved this report. The authors also thank Rob Taylor for generating various maps included in this report and to Hyeonsup Lim who assisted in reviewing the draft report. 



\section{ACRONYMS}

ACS American Community Survey

CPI-U Consumer Price Index for All Urban

FHWA Federal Highway Administration

FY Fiscal Year

GTFS General Transit Feed Specification

HUD United States Department of Housing and Urban Development

JTW Journey to Work

MFI Median Family Income

MSA Metropolitan Statistical Areas

NCLEJ National Center for Law and Economic Justice

NHTS National Household Travel Survey

NYC New York City

NYMTC New York Metropolitan Transportation Council

NYS New York State

PMT Personal Miles Traveled

POV Privately Owned Vehicle

PT Person Trip

TFAH Trust for America's Health

USDOT U.S. Department of Transportation

VMT Vehicle Miles Traveled

VT Vehicle Trips 



\begin{abstract}
Studies have shown that people residing in poverty face more mobility challenges in their daily travels as compared to those living in higher income households. In many cities, the lack of a public transportation systems and investments in low-income areas are making it difficult for those living in poverty to access jobs, goods, and services (schools, groceries, health cares, etc.). In this study, Oak Ridge National Laboratory was tasked by the New York State (NYS) Department of Transportation to conduct a detailed examination of the travel behaviors and identify patterns and trends of the low-income residents within NYS.

The 2009 National Household Travel Survey data was used as the primary information source to analyze subjects associated with poverty and mobility, and to address questions Such as are there differences in traveler demographics between the low-income population and those of others who live in various NYS regions (e.g., New York City, other urban areas of NYS)? How do they compare with the population at large (e.g., rest of the country) or with findings from previous years (i.e., trend)? Are there any regional differences (e.g., urban versus rural)? Do any unique travel characteristics or patterns exist within the low-income group?

Through this study, various key findings on low-income population sizes, household characteristics, travel patterns, and mobility limitations were identified and summarized in this report.
\end{abstract}





\section{EXECUTIVE SUMMARY}

This study identifies key characteristics of very-low income households in New York State (NYS), their travel patterns, and mobility limitations based on the 2009 NHTS. The study reveals that the proportion of very-low income households is higher in New York City (NYC), especially in counties outside Manhattan. The likelihood of having no drivers or no vehicles is much higher in NYS's very-low income households, as compared to those in other income groups. As a result, the very-low income households in NYS used a personally owned vehicle (POV) less frequently than other income households on their daily trips, while the share of using public transit for daily travels is much higher among the very-low income households. Generally, a very-low income household in NYS made fewer trips than other income level households did, due to mobility limitations.

\section{Great concentration of very-low} income households in NYC
Based on the 2009 NHTS, $29 \%$ of NYS residents (ages 5 years and older) lived in very-low income households, with the greatest concentration in NYC. One in four persons who lived in Manhattan came from a very-low income household, as compared to $44 \%$ for those who lived elsewhere in NYC.

Poverty rates among African-American and Hispanic populations are significantly higher than other races among NYS residents. The share of very-low income Hispanic populations in NYS went from 44\% in 1995 to $63 \%$ in 2009, while the rate among African-Americans remained under $50 \%$ in this time. On the other hand, the share of very-low income for their counterpart White neighbors stayed under $20 \%$ during the same period. Nearly two in five of the very-low income NYS households were single occupant in 2009, while it was less than one in four among other income households living in NYS during the same year. The majority of the very-low income residents who lived alone in NYS were retired persons.

According to the 2009 NHTS data, 22\% of very-low income households in NYS reported having no drivers in their households, as compared to only $3 \%$ among their other income neighbors. Half of all very-low income households in NYS did not own any vehicles in 2009, compared to only $16 \%$ of their other income neighbors. The likelihood of being a zero-vehicle household in NYC is significantly higher than being one in areas outside of NYC. Outside NYS, very-low income households also had a higher likelihood of owning no vehicles than their other income neighbors, with shares of $20 \%$ versus $2 \%$ respectively.

Limited mobility for very-low income households
The NHTS data shows that mobility for individuals from a very-low income household was more limited than that of other income individuals. Very-low income

NYS residents traveled $56 \%$ fewer miles on average, as compared to trips taken by other income level New Yorkers. Furthermore, while NYS residents with other income levels traveled an average of 3.95 trips daily during 2009, a very-low income individual from NYS took nearly $22 \%$ fewer trips on a daily basis in the same year. 
NYS's very-low income residents were more likely to use public transit, with a lower likelihood of using POV, for their daily travel. In NYC, only $47 \%$ of trips made by very-low income residents were by POV, as compared to about 70\% among other income groups. Mode share for person-trips made by walking was also significantly higher among very-low income New Yorkers. Furthermore, New Yorkers who lived in very-low income households were more likely to travel for family/personal business and school/church activities, but less likely to travel for work and social/recreational purposes as compared to their neighbors with other incomes.

\section{Transit is essential for NYS's very-} low income households
Essentially, $84 \%$ of NYS's very-low income populations lived within a one-mile radius of transit stations, while only $17 \%$ of the other-income New Yorkers lived within the same range. Nearly $35 \%$ of all persons in NYC with income under $\$ 25,000$ used public transit, as compared to $13 \%$ for those who are in the $\$ 100,000+$ income category. Moreover, children from NYC households with income under $\$ 25,000$ had the highest likelihood of taking public transit.

About 50\% of the very-low income households in NYS did not own any vehicles. Most of these zero-vehicle very-low income households were located in NYC. Most trips taken by individuals from zero-vehicle households within Manhattan in 2009 were made by walking, and accounted for $62 \%$ of all daily person-trips taken regardless of income status.

NYC drivers from a very-low income elderly household traveled a significantly fewer amount of POV trips than their counterpart New Yorkers who lived outside NYC, regardless of household size. The influence of income on travel frequencies seems to be less among children. Specifically, children of very-low income households made about $19 \%$ fewer trips than children in other income level households in 2009, as compared to $28 \%$ among those over 15 years old.

Price is the most important to verylow income New Yorkers
In all regions, except for Manhattan and PutnamRockland-Westchester, New Yorkers from a very-low income household were more likely to reflect "price of travel" as a big issue than their counterpart other income neighbors. Over three in five of those very-low income New Yorkers indicated "price of travel" was the most important issue. "Aggressive/distracted drivers" was also expressed as a big issue by nearly $60 \%$ of the very-low income New Yorkers, who identified this as their most important concern. The concern for "access/availability of public transit" was only considered a big issue by half of those very-low income NYS residents that identified it as their most important issue. Outside of NYS, the "price of travel" was reflected as a big issue by $65 \%$ of the very-low income individuals who said that "price of travel" was their most important concern. 



\section{INTRODUCTION}

\subsection{BACKGROUND}

Studies have shown that households in poverty face more mobility challenges in their daily travels as compared to other income households. In many cities, the lack of public transportation systems and investments in low-income areas are making it difficult for those living in poverty to access jobs, goods, and services (schools, groceries, health cares, etc.). Furthermore, race and transportation have long been known to be intertwined. In 2009, the year of the most recent National Household Travel Survey (NHTS) data, as quoted in a Federal Highway Administration (FHWA) released NHTS brief, the Census Bureau reported that nearly 26\% of blacks and 25\% of Hispanics in the United States lived in poverty, whereas the official overall poverty rate for all races was 14.3 percent $^{1}$. As suggested in a snapshot report ${ }^{2}$ released by the National Center for Law and Economic Justice (NCLEJ) in 2014, the poverty rate in the U.S. has not seen any improvements over many years. While about $15 \%$ of the total U.S. population lived in poverty in 2014, more than $26 \%$ of African-Americans and nearly $24 \%$ of Hispanics were in poverty in 2014. In comparison, only $10 \%$ of non-Hispanic White and $12 \%$ of Asian populations were in poverty during the same year.

The research documented in this report is a detailed examination of the travel behaviors and patterns of low-income populations within New York State (NYS). This study is primarily based on travel data provided by the 2009 NHTS and the associated Add-On sample households purchased by the New York State Department of Transportation (NYSDOT). Unlike many studies that concentrated on national level statistics, this research focused on examining issues associated with NYS travelers of low-income households. As the needs for comparison were raised, certain travel behaviors and characteristics associated with residents in the rest of the country (as a whole) were also analyzed under this study.

Using Census 5-year American Community Survey (ACS), 2008-2012, Figure 1-1 shows the median household income for all counties in NYS. Clearly, the median incomes of counties within the New York Metropolitan Transportation Council (NYMTC) region are much higher than all other NYS counties, except for Bronx and Kings. Note that over $60 \%$ of the NYS population resides within the NYMTC region, which includes the counties with the highest and the lowest median incomes in NYS - Nassau County and Bronx County, respectively. Interestingly, the median income level of Saratoga County in upstate NYS is more similar to those other income NYMTC counties than its neighboring counties. Outside of NYMTC, as seen in Figure 1-1, rural counties typically have lower median incomes (shaded in orange color).

\footnotetext{
${ }^{1}$ FHWA NHTS Brief - Mobility Challenges for Households in Poverty, http://nhts.ornl.gov/briefs/PovertyBrief.pdf, released by Federal Highway Administration, U.S. Department of Transportation, 2014.

2 "Poverty in the United States: A Snapshot," National Center for Law and Economic Justice, November 4, 2015. www.Nclej.org/snapshot/poverty-in-the-united-states/ accessed March 2017.
} 


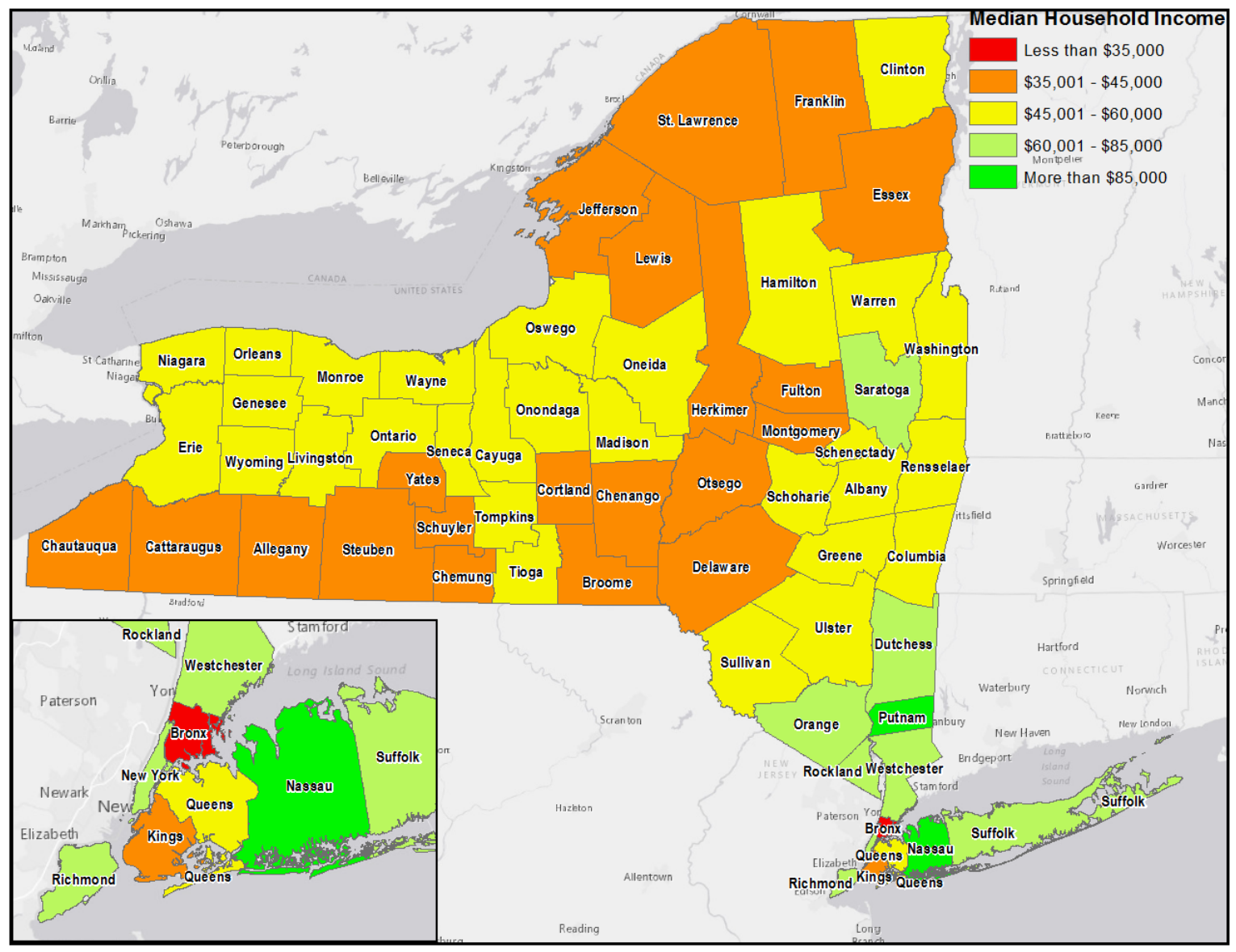

Figure 1-1. Median family income in NYS counties (ACS 2008-2012 data)

\subsection{PURPOSE OF THIS STUDY}

The purpose of this study was to answer questions such as the following:

- Are there differences in traveler demographics between the low-income population and those of other populations who lived in various NYS regions, e.g., New York City (NYC), other urban areas of NYS, or other parts of the country?

- How do they compare with the population at large?

- Are there any regional differences (e.g., urban versus rural)?

- Do any unique travel characteristics or patterns exist in the low-income households?

\subsection{ORGANIZATION OF REPORT}

This report presents data analysis results based on travel generated by NYS low-income households. Specifically, statistics on traveler demographics, mode-specific summary statistics such as frequency (i.e., trip rate), mode choice, distance (trip length), time of trip, and trip 
purpose of the NYS low-income population were examined. Section 2 of this report describes characteristics of the low-income population in NYS, including the population size, their demographic profiles, household living arrangements, vehicle ownership and vehicle age. Travel characteristics for the low-income population are addressed in Section 3, followed by a discussion on associated mobility statistics in Section 4. The topic of transportation accessibility and equality, particularly on more vulnerable population groups (e.g., poor and with zerovehicle, children in poverty) are discussed in Section 5. Influence of income on NYS residents' views regarding transportation quality was also examined and results are included in Section 6 of this report. Finally, a summary of key findings from this research is in Section 7. A glossary listing definitions of general terms used in this report is provided in Appendix A, with additional supporting statistics (summarized in several tables) listed in Appendix B. 



\section{BRIEF DESCRIPTIONS OF DATA SOURCES}

Data used to analyze low-income household characteristics and their travel behaviors were obtained from the NHTS and supplemented with data from the U.S. Census Bureau (Census), as well as other sources as appropriate. These data sources are briefly described below.

\subsection{NHTS}

Overall, statistics discussed in this report were produced using data from the 2009 NHTS. The NHTS is a Federal Highway Administration (FHWA)-sponsored national travel survey of U.S. households; it surveyed over 150,000 households in 2009. ${ }^{3}$ According to the NHTS website, "the NHTS is the authoritative source of national data on the travel behavior of the American public." The NHTS includes questions about trip frequency, distance, travel time, and modes of transportation, including walking and bicycling. Survey data from previous years (i.e., 1995 and 2001) were also considered in this study, specifically when trends or changes over time were considered. Note that NHTS collected information from populations that were age 5 years old and older at the survey time only.

Note that the 2009 NHTS samples composed of a national sample set of about 25,000 households and separate samples from 20 Add-On areas, which added a combined total of 125,000 plus sample households to the national samples (i.e., adding 5 times more samples to the national sample size). Clearly, without the Add-On samples, the use of NHTS data for any detailed analyses (spatially or temporally) would be extremely limited.

As a participant of the 2009 NHTS Add-On program, the NYS Department of Transportation (NYSDOT) received travel data for nearly 16,200 of the state's households. This allows NYSDOT analysts to have sufficient samples for examining their residents' travel behaviors and to address transportation planning issues pertinent to geographic areas significantly smaller than what the NHTS data intended.

\subsection{CENSUS DATA}

Additional information and data sources were also utilized, along with the NHTS data, in order to examine travel behavior and patterns associated with the NYS low-income population. Specific subjects included investigation on mobility of the low-income population and other travel limitations. The data set from the Census Bureau (i.e., ACS) was also used when appropriate, especially in examining the size of the low-income population.

The ACS is a survey conducted by the U.S. Census Bureau of about 3 million households annually ( 250 thousand per month), and is subject to the constraint that households should not be surveyed more than one time in any five-year period. Thus, the ACS is very intensive-about 20

\footnotetext{
${ }^{3}$ U.S. Territories are not included in the NHTS sampling frame and excluded population under 5 years old.
} 
times as big as the NHTS (3 million versus 150 thousand) - and it is repeated annually. The ACS is also, geographically, more uniform than the NHTS. Each year's ACS sample includes, on average, almost 50 households per Census Tract and almost 15 households per Block Group. Data on demographic, social, and economic characteristics for all ages of populations living in the U.S. is collected in the ACS. The ACS also collects data on commuting, i.e., the Journey to Work (JTW), including mode of transportation and travel time to work.

\subsection{ADDITIONAL INFORMATION SOURCES}

Information from the U. S. Department of Housing and Urban Development (HUD), particularly data relating to income limits, is used to frame the targeted population for this study. Income limits are set by HUD and used to determine the income eligibility of applicants for public housing. The limits are based on HUD estimates of median family income (MFI) for each fiscal year (FY). The most recent (FY2016) income limits for the HUD Public Housing and Section 8 Programs became effective on March 28, 2016 ${ }^{4}$. As stated in the Notice issued by HUD on March 28, 2016, the most important statutory provisions relating to income limits are:

- $\quad$ very low-income is defined as 50 percent of the MFI for the area, subject to specified adjustments for areas with unusually high or low incomes relative to housing costs;

- $\quad$ low-income is defined as 80 percent of the MFI for the area, subject to adjustments for areas with unusually high or low incomes or housing costs;

- $\quad$ extremely low-income is defined as an income targeting standard in the 1998 Amendments to the Housing Act of 1937; to avoid inconsistencies with other income limits, it is defined as 60 percent of the four-person family very low-income limit, adjusted for family size, but under the Consolidated Appropriations Act, 2014, not allowed to fall below the poverty guidelines as determined by the Department of Health and Human Services;

- where the area income limit is less than the state nonmetropolitan MFI, income limits are based on the state nonmetropolitan median; and

- income limits are adjusted for family size so that larger families have higher income limits.

\subsection{DEFINITIONS OF LOW-INCOME HOUSEHOLDS}

To examine travel patterns of the low-income population properly, it is important to define what constitutes a low-income household. Three general approaches can be found in the literature for defining low-income households and they are briefly discussed below.

\footnotetext{
${ }^{4}$ Transmittal of Fiscal Year (FY) 2016 Income Limits for the Public Housing and Section 8 Programs, Notice PDR2016-02, issued March 28, 2016, https://www.huduser.gov/portal/datasets/il/il16/HUD-sec8-FY16.pdf.
} 


\subsubsection{Simple Cutoff Value or Category}

The use of a simple cutoff value, which defines a low-income household as one with income below a pre-determined cutoff dollar amount, is one of the most common approaches seen in the literature. This method is straightforward, and thus easy to apply. In most cases, household incomes are categorized into several buckets (ranges of income level), with the lowest one being classified as the "low-income" group. For example, Pucher and Renne used a household income of $\$ 20,000$ as the cutoff value to define low-income households in their 2003 paper regarding urban travel based on the 2001 NHTS data ${ }^{5}$. A 2012 FHWA Profile, entitled Travel Profile of the United States ${ }^{6}$, used $\$ 25,000$ as its cutoff value for the lowest household income category using 2009 NHTS data. In an issue-report compiled by the Trust for America's Health (TFAH) and released by the Robert Wood Johnson Foundation in July 2011, entitled F as in Fat: How Obesity Threatens America's Future ${ }^{7}$, the authors applied $\$ 15,000$ as the cutoff for household income in the lowest category. This cutoff value was subsequently raised to $\$ 25,000$ in the TFAH-prepared issue-report for 2013.

\subsubsection{Census Bureau Poverty Threshold}

The Census Bureau reports income and poverty estimates from several major national household surveys and programs, including the ACS, Survey of Income and Program Participation, Small Area Income and Poverty Estimation Program, Census 2000 long form, and the Annual Social and Economic Supplement to the Current Population Survey. According to information posted on the Census' "The History of the Official Poverty Measure" website ${ }^{8}$, the current official poverty measure was developed in the mid-1960s when President Lyndon Johnson declared a "war on poverty." Census publishes the official poverty thresholds annually (in dollars), and each annual set is updated for inflation using the Consumer Price Index for All Urban Consumers (CPI-U) published by the Bureau of Labor Statistics. Although the poverty thresholds vary by family size and number of children, the same thresholds are applied throughout the U.S. The official Census poverty thresholds do not take into consideration any geographic differences in the cost of living. However, many researchers used the Census poverty thresholds to define low-income households or persons in their studies, including reports from various public and private agencies (e.g., Working Poor Families Project ${ }^{9}$, National Center for

\footnotetext{
${ }^{5}$ John Pucher and John L. Renne, "Socioeconomics of Urban Travel: Evidence from the 2001 NHTS," Transportation Quarterly, Vol. 57, No. 3, Summer 2003 (49-77).

${ }^{6}$ Travel Profile of the United States, 2012, http://nhts.ornl.gov/2009/pub/profile_2012.pdf..

${ }^{7} \mathrm{~F}$ as in Fat: How Obesity Threatens America's Future, July 2012, http://www.tfah.org/assets/files/TFAH2011FasInFat10.pdf.

${ }^{8}$ The History of the Official Poverty Measure, U.S. Census Bureau, http://www.census.gov/topics/incomepoverty/poverty/about/history-of-the-poverty-measure.html, accessed November 2016.

${ }^{9}$ Roberts, B., D. Povich, and M. Mather, "Low-Income Working Families: The Growing Economic Gap," Policy Brief Winter 2012-2013, http://www.workingpoorfamilies.org/wp-content/uploads/2013/01/Winter-2012_2013WPFP-Data-Brief.pdf.
} 
Children in Poverty ${ }^{10}$ ). For the official Census poverty thresholds for 2009, see Table B-2 in Appendix B.

\subsubsection{HUD Very-Low-Income}

As discussed previously in Section 2.3 of this report, HUD's income limits were set and used to determine the income eligibility of applicants for public housing. To serve that purpose, these limits are defined by a MFI-based measure, which varies by family size and their geographical area. By using this method, differences in housing markets and costs of varying regions can be accounted for in HUD's income limits. Clearly, geographical difference is an important factor that needs to be considered, so that very-low-income households among NYS residents can be accurately identified and their travel behaviors can be properly examined.

As an example, Table B-3 in Appendix B provides a partial list of HUD's FY2009 very-low income limits for NYS which shows the very-low income limits for Metropolitan Statistical Areas (MSA) and several counties in NYS. Similarly, HUD's 2009 limits were selected in order to better align with the 2009 NHTS data used in this study. The highlighted rows in Table B-3 show two counties with the highest and the lowest very-low income limits within the NYS, e.g., Westchester County (shaded in light green) and Allegany County (highlighted in yellow), respectively. Note that, by HUD definitions, the same income limits could be applied to multiple counties/regions. Using information shown in Table B-3 as the example, several NYS counties share the same set of lowest very-low income limits, although their MFI values are slightly varied. As a reference, in NYS, the county with the highest MFI in 2009 is Westchester County $(\$ 105,300)$ and the lowest MFI during the same year is St. Lawrence County $(\$ 49,600)$.

\subsection{COMPARISON OF CENSUS POVERTY THRESHOLDS AND HUD'S VERY-LOW INCOME LIMITS}

The national poverty level based on the Census definition is clearly lower than both sets of HUD-defined limits for NYS. This is certainly expected given the high cost of living and housing market in NYS, especially in the NYC area, as compared to the nation in general. For example, a family of four in 2009 would have a Census poverty threshold of $\$ 21,954$, while the HUD very-low income level for the NYS lowest-MFI county (St. Lawrence) is \$27,450-25\%, which is higher than the Census amount. On the other hand, the HUD very-low income level for a family of four living in the highest-MFI county of NYS (Westchester) is $\$ 52,650$, which is about $140 \%$ higher than the Census defined poverty threshold. Certainly, many families in NYS would not be identified as very-low income if the Census definitions were applied. For an

\footnotetext{
${ }^{10}$ United States Demographics of Low-Income Children, National Center for Children in Poverty, http://www.nccp.org/profiles/US_profile_6.html, accessed November 2016.
} 
illustration of the differences in income level by family size using national data from the Census weighted-average poverty thresholds and the NYS-specific data for very-low income limits from HUD for the highest and the lowest counties, see Figure B-1 in Appendix B.

In conclusion, the HUD-defined very-low income limits are considered more realistic in reflecting the cost of living and housing markets in NYS. Explicitly, HUD very-low income limits were used to frame the scope of this study, which is to examine NYS low-income residents' travel behaviors and associated characteristics using the 2009 NHTS data. Similarly, HUD-defined very-low income limits are also applied to identify equivalent low-income households from outside of NYS (i.e., households from the Rest of U.S.) for all comparison purposes.

\subsection{CURRENT STUDY AND ANALYSIS FOCUS}

\subsubsection{Geographical Region Considerations in Data Analysis}

Typically, when sample size permits, statistics generated from analyses conducted under this study are presented by major geographical regions in the NYS. Specifically, these areas might include:

- New York City (NYC) - which includes five counties/boroughs: Manhattan/New York County, Kings County, Queens County, Richmond County, and Bronx County;

○ Manhattan - includes New York County only;

○ Rest of New York City - consists of the other four boroughs of NYC excluding Manhattan;

- New York Metropolitan Transportation Council (NYMTC) - includes the aforementioned five boroughs of NYC, plus Nassau, Suffolk, Putnam, Rockland, and Westchester counties;

- Rest of NYS - includes all areas outside the NYMTC as a whole. When possible, this could be further divided into:

○ Other Urban Areas (excluding NYMTC) - includes all urban areas in NYS other than NYMTC,

○ Non-Urban Areas - includes all non-urban areas in NYS,

- NYS Statewide - this is the same as NYS, which consists of all areas in the NYS as a whole.

The Rest of United States (Rest of U.S.) is used as a combined geographic region when comparing behaviors from those who lived elsewhere in the United States (i.e., outside the NYS). 


\subsubsection{Scope of Population and Households}

To be consistent with a similar previous study conducted using 2001 NHTS data, this study focuses on travel behaviors of households that fall below the HUD-defined very-low income limits. The rationale of applying HUD's "very-low income" limits to classify the targeted low income population in NYS, instead of using HUD's "low income" limits, was mainly because the use of HUD's low income limits would classify nearly $45 \%$ of all NYS households into the "low income" group in 2009 (Figure 2-1). On the other hand, with HUD's very-low income limits, less than $30 \%$ of NYS households are categorized into the targeted study group. Consequently, using the HUD very-low income limits as the cutoff for "low income" in this study allows for a better focus on the travel behaviors and mobility limitations of the most underprivileged NYS population.

Hereafter in this report, both terms ("low-income" and "very-low income") refer to the same study population, i.e., those with a household income below the HUD-defined, areaspecific, very-low income limits. Moreover, in this study, people from these low-income households are considered to be living in poverty. For a reference, HUD's very-low income limits used in this study are provided by region of residence and listed in Appendix Tables B-1A, $\mathrm{B}-1 \mathrm{~B}$, and $\mathrm{B}-1 \mathrm{C}$ of this report. A look at persons and households by region for very-low and other income level is found in Appendix Tables B-2A, B-2B, and B-2C.

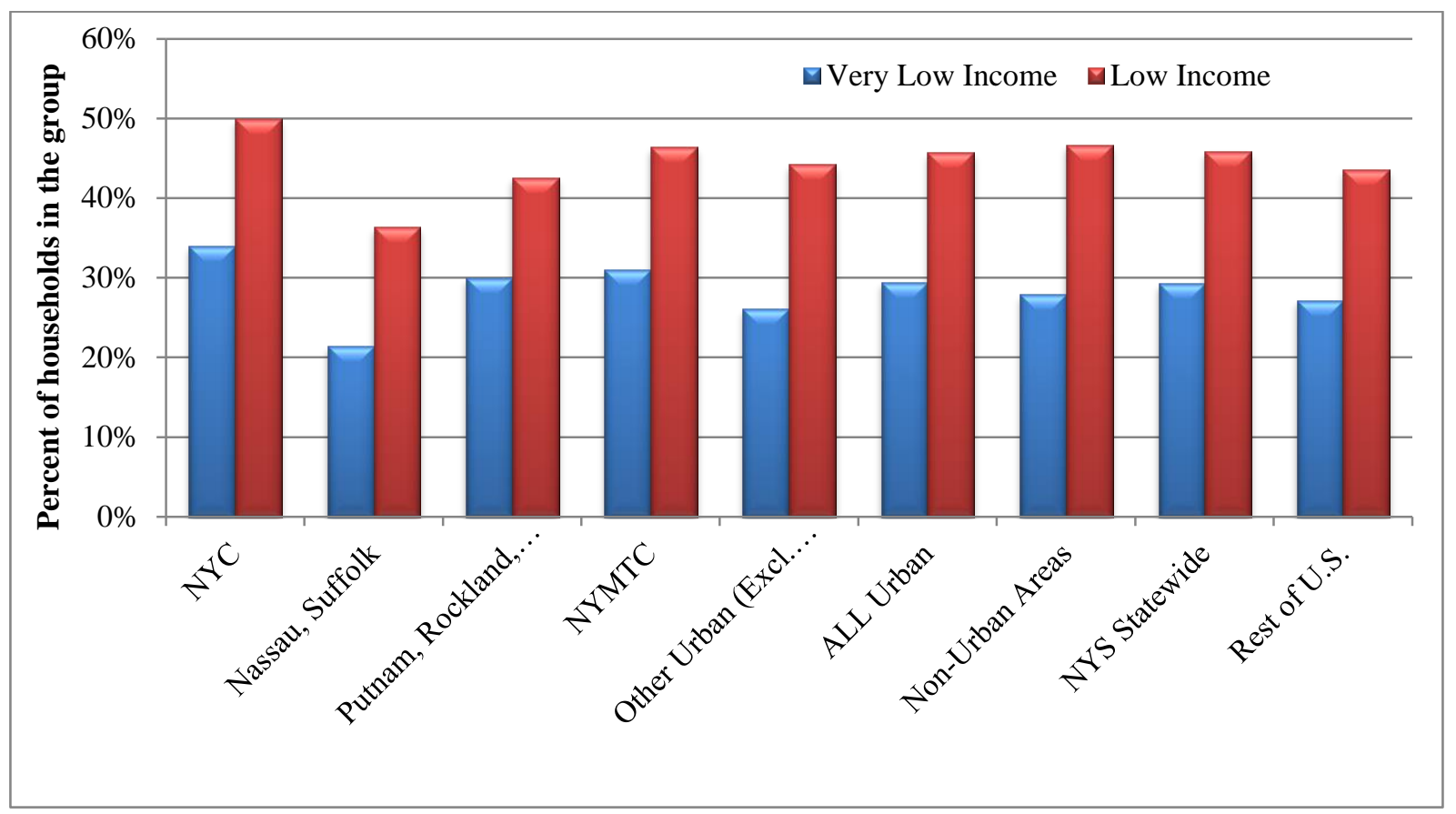

Figure 2-1. Percent of households in HUD-defined very-low income vs. low income groups (2009 NHTS) 



\section{CHARACTERISTICS OF THE NYS LOW-INCOME POPULATION}

\subsection{OVERVIEW}

Using NHTS data from the three survey years (1995, 2001, and 2009), Figure 3-1 shows that NYS residents have a higher rate of being in a very-low income household than residents outside of NYS. Specifically, more than one in four NYS residents lived in poverty, about 4-6\% higher over the three NHTS years, when compared to residents from the Rest of U.S. These regional differences are all statistically significant. ${ }^{11}$

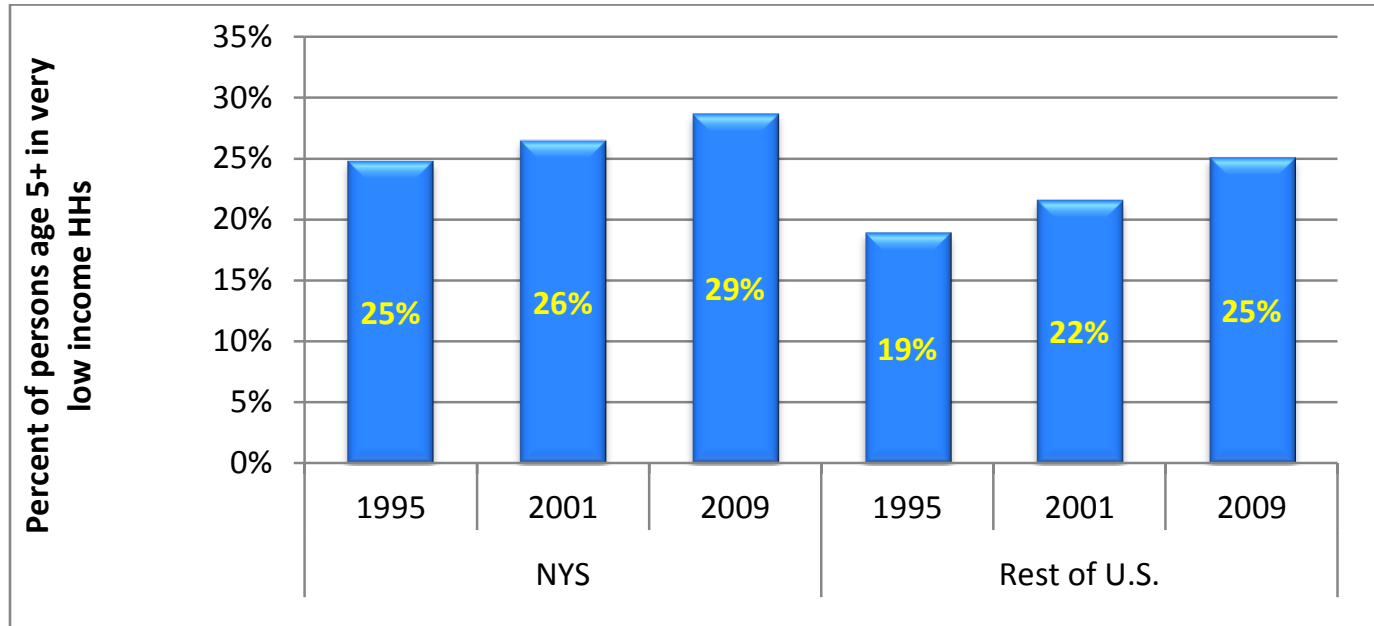

Figure 3-1. Share of population age 5 year and older in very-low income households (NHTS data).

Similarly, Figure 3-2 presents the corresponding shares of very-low income households. While $32 \%$ of NYS households fell under the very-low income limits in 2009, only about $23 \%$ of households located outside of NYS are in the same income category. This significant regional difference in shares of very-low income households can also be observed in previous NHTS years (i.e., 1995 and 2001). Both Figure 3-1 and Figure 3-2 show an increasing trend in poverty rates over the period from 2001 to 2009 , regardless of where the population resided.

\footnotetext{
${ }^{11}$ The "statistical significance" referenced throughout this report were all based on a 95\% significance level, unless otherwise specified.
} 


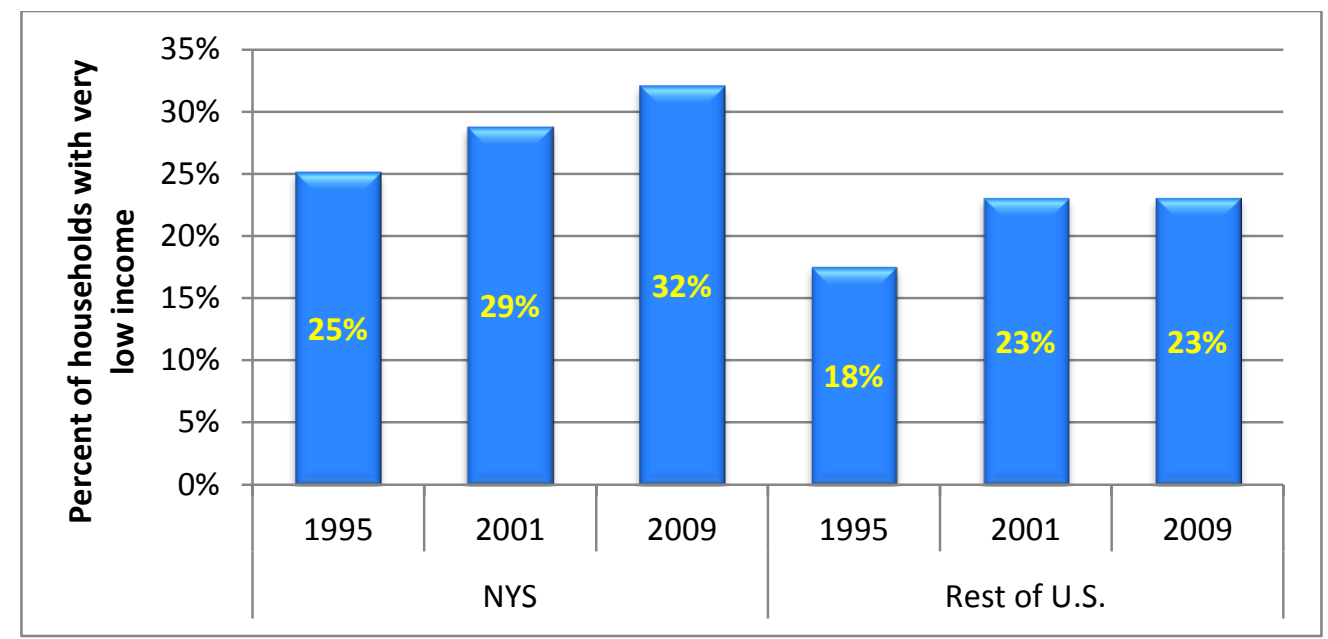

Figure 3-2. Shares of households with very-low income status (NHTS data)

\subsection{GEOGRAPHIC DISTRIBUTION OF LOW INCOME NYS HOUSEHOLDS}

Because of sampling limitations, NHTS samples were not sufficient to reflect shares of verylow income households properly for all counties. Using the 5-year ACS data for 2008-2012 ${ }^{12}$, Figure 3-3 displays the percent of population that fell below the poverty level in each NYS county. For this map, counties with orange and red colors are counties with more than $20 \%$ of its population being in the poverty level. Furthermore, because poverty level was derived based on MFI, the patterns shown in Figure 3-3 and Figure 1-1 are similar. (Note that different colors were used to distinguish between MFI and poverty rate.) Typically, a higher MFI area is more likely to have a lower poverty rate. That is, Bronx and Kings are the two counties with the highest poverty rates in NYS (Figure 3-3), and in terms of MFI, they are the counties with the lowest median incomes (Figure 1-1).

\footnotetext{
12 American Community Survey (ACS) 2014, U.S. Census Bureau website accessed at http://www.census.gov/acs/www/, accessed in November 2016.
} 


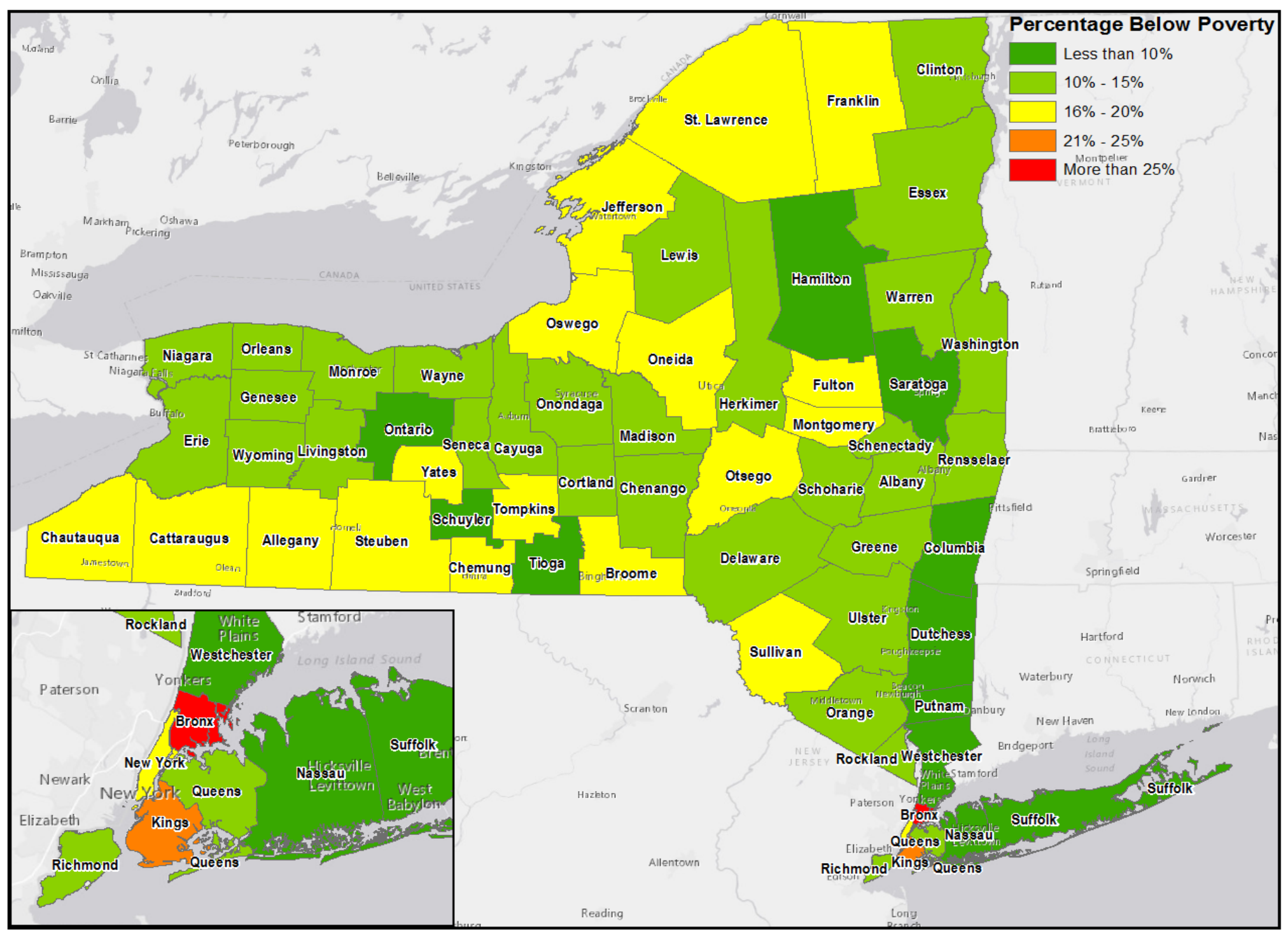

Figure 3-3. Percent of population below poverty level in NYS counties (ACS 2008-2012 data)

Based on NHTS data, the amount of population in very-low income households (includes persons aged 5 years and older only), and their share in the overall population, are presented in 
Table 3-1 for selected NYS areas, as well as the area outside NYS (i.e., in the Rest of U.S.). Clearly, NYC (i.e., combined Manhattan and the "Rest of NYC" areas) has a higher geographical concentration of very-low income households than areas outside of NYC. Note that both Bronx and Kings mentioned above are included under the "Rest of NYC" area, which clearly contributed to the high percent share of very-low income households for that region as seen in 
Table 3-1. Nearly $44 \%$ of all residents in the Rest of NYC area resided in very-low income households during 2009. Nassau and Suffolk, on the other hand, are counties with the lowest share of population in poverty (shown in Figure 3-3). Thus, only about $21 \%$ of the population from this area was classified as very-low income in 2009. 
Table 3-1. Very-low Income Households in NYS by areas (NHTS data)

\begin{tabular}{|c|c|c|c|c|c|c|}
\hline \multirow[b]{2}{*}{ Resident location } & \multicolumn{2}{|c|}{2009} & \multicolumn{2}{|c|}{2001} & \multicolumn{2}{|c|}{1995} \\
\hline & $\begin{array}{l}\text { Population in } \\
\text { very-low } \\
\text { income } \\
\text { households }\end{array}$ & $\begin{array}{c}\text { Percent } \\
\text { population in } \\
\text { very-low } \\
\text { income* } \\
\text { households }\end{array}$ & $\begin{array}{l}\text { Population in } \\
\text { very-low } \\
\text { income } \\
\text { households }\end{array}$ & $\begin{array}{c}\text { Percent } \\
\text { population in } \\
\text { very-low } \\
\text { income* } \\
\text { households }\end{array}$ & $\begin{array}{l}\text { Population in } \\
\text { very-low } \\
\text { income } \\
\text { households }\end{array}$ & $\begin{array}{c}\text { Percent } \\
\text { population in } \\
\text { very-low } \\
\text { income* } \\
\text { households }\end{array}$ \\
\hline Manhattan & 360,337 & $24.9 \%$ & 335,804 & $26.7 \%$ & 353,182 & $30.8 \%$ \\
\hline Rest of NYC & $2,548,724$ & $43.7 \%$ & $2,190,996$ & $39.5 \%$ & $1,617,951$ & $37.3 \%$ \\
\hline Nassau, Suffolk & 523,147 & $20.9 \%$ & 346,927 & $15.2 \%$ & 334,087 & $17.2 \%$ \\
\hline $\begin{array}{l}\text { Putnam, Rockland, } \\
\text { Westchester }\end{array}$ & 333,477 & $28.3 \%$ & 240,798 & $22.3 \%$ & 137,695 & $15.6 \%$ \\
\hline $\begin{array}{l}\text { Other Urban } \\
\text { (Excludes } \\
\text { NYMTC) }\end{array}$ & $1,082,988$ & $24.1 \%$ & 753,235 & $19.3 \%$ & 588,019 & $16.5 \%$ \\
\hline Non-Urban Areas & 392,321 & $24.0 \%$ & 375,350 & $19.4 \%$ & 360,898 & $20.0 \%$ \\
\hline NYS Statewide & $5,200,606$ & $30.7 \%$ & $4,243,110$ & $26.5 \%$ & $3,391,832$ & $24.8 \%$ \\
\hline Rest of U.S. & $66,417,900$ & $26.4 \%$ & $48,410,575$ & $21.6 \%$ & $35,499,832$ & $18.9 \%$ \\
\hline
\end{tabular}

* Excludes households that did not report income information

For an easy comparison by region and over time, the population shares for very-low income households are charted and shown in Figure 3-4. A growing pattern of very-low income population-share over the three NHTS years can be observed for all regions, with the exception of Manhattan. Due to sample variations (i.e., relatively large standard errors), however, the growth rate was not statistically significant in most disaggregated regions.

On the other hand, the growth of very-low income share over time is significant at the geographically aggregated level, such as non-NYMTC urban areas of NYS (i.e., other urban) and NYS statewide, as well as the Rest of U.S. Furthermore, the difference in poverty rates between the NYS statewide and the Rest of U.S. was clearly influenced by NYC, in which $56 \%$ of NYS's total very-low income population (ages of 5 years and older) resided in 2009 - this percentage was calculated based on $(360,337+2,548,724) / 5,200,606$ (see Table 3.1$)$. 


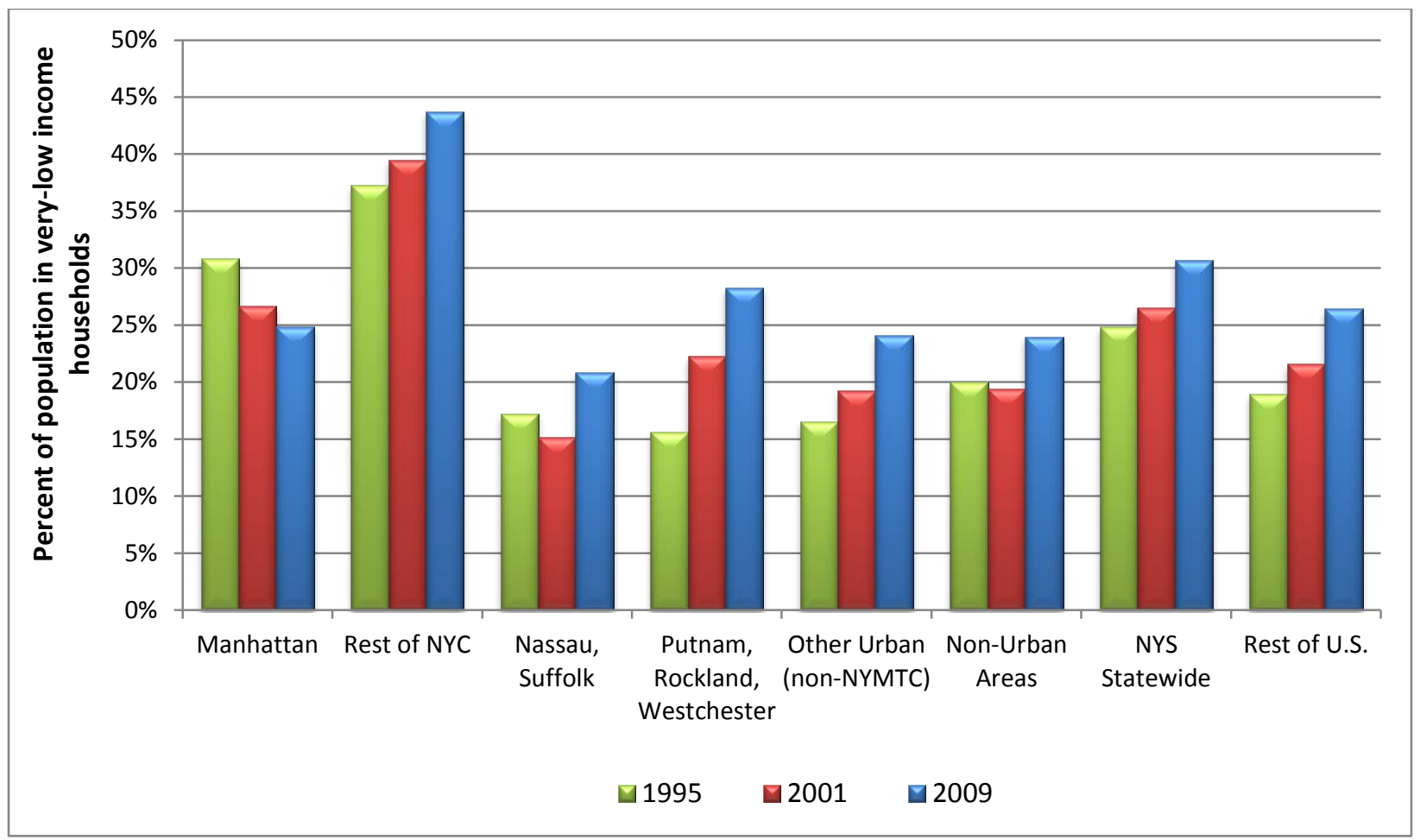

Figure 3-4. Population share of very-low income households by region (NHTS data)

\subsection{NHTS-BASED DEMOGRAPHIC PROFILE OF NYS VERY-LOW INCOME POPULATION}

\subsubsection{Impacts of Race}

As shown in Figure 3-5, poverty rates among African-American and Hispanic populations are significantly higher than other races among NYS residents for all three NHTS years. In addition, the growth of very-low income population share is particularly visible among NYS's Hispanic populations. For NYS residents, poverty rates for Hispanics went from $44 \%$ in 1995, to $55 \%$ in 2001, then to $63 \%$ in 2009; while the poverty rates among African-American remained under $50 \%$ during the same period of time (ranging from $42 \%-49 \%$ ) and their counterpart White residents stayed under $20 \%$.

Outside of NYS, the Hispanic population also has a higher rate of being in a very-low income household than all other races. For instance, in 2009, the share of very-low income population was 55\% among the Hispanic population residing in the Rest of U.S., while only $41 \%$ of their African-American and 19\% of their White neighbors were in the same income level. Similar to NYS residents, the growth of very-low income population share is also more significant among Hispanic populations living in the Rest of U.S. 


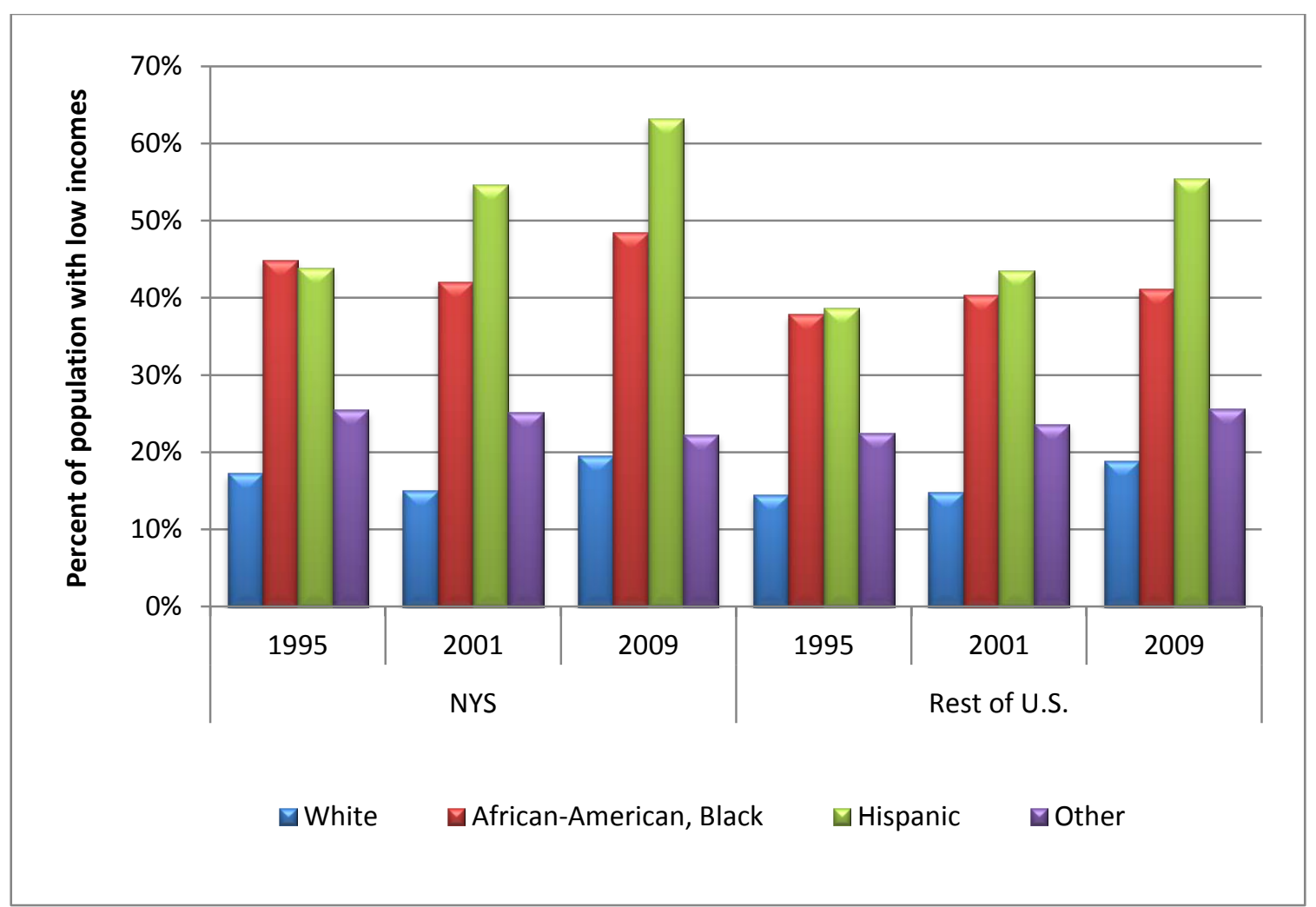

Figure 3-5. Percent of population with very-low income by race and time (NHTS)

\subsubsection{Driver Availability}

Figure 3-6 illustrates the relationship between household income level and the likelihood of being a driver by resident locations. Regardless of where a person lives, i.e., NYC, the Rest of NYS, or the Rest of U.S., the likelihood of the person being a driver increases as his/her household income level increases. Not surprisingly, the likelihood of being a driver for a NYC resident is smaller than a resident from the other two regions. This is mainly due to the intensity of public transit availability within NYC. In fact, the likelihood for residents from the Rest of NYS is very similar to those from the Rest of the U.S.

About $74 \%$ of the driving age population from the lowest income group (under \$25,000) who lived outside NYC were drivers in 2009 compared to only about $53 \%$ of their NYC counterparts. Note that the likelihood of being a driver for those who did not respond to the income question was also charted in Figure 3-6 for reference. About 58\% of those non-respondent driving age persons from NYC are drivers, while nearly $85 \%$ of their counterparts living outside of NYC are drivers. 


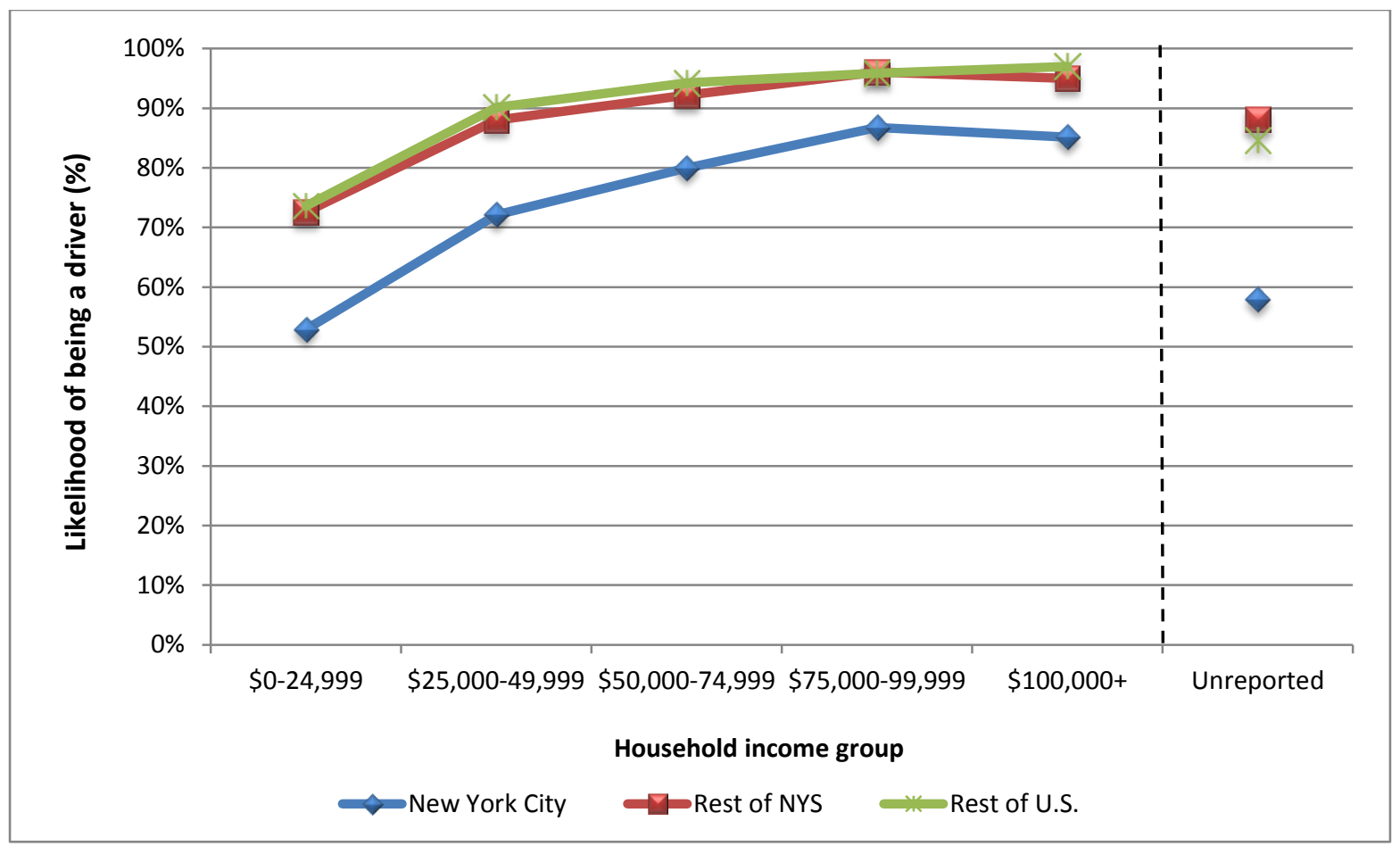

Figure 3-6. Likelihood of being a driver by household income category (NHTS 2009 data)

Furthermore, a very-low income household has a higher likelihood of having no drivers, as compared to other income households. As displayed in Figure 3-7, according to 2009 NHTS data, 22\% of very-low income households in NYS had no drivers in their households as compared to only $3 \%$ of their counterparts from other income households. Overall, the share of zero-drivers in NYS households has seen a decrease between 2001 and 2009 - dropping from over 30\% in 2001 to about $22 \%$ in 2009 (about a 28\% decrease from the 2001 level) for the verylow income group. For the other income group, the zero-driver rate dropped from 5\% to $3 \%$ (a $40 \%$ change) during the same period.

With respect to geographical regions, Figure 3-8 shows that the share of very-low income households without access to any drivers does vary among NYS regions. With a broad availability of public transit systems in NYC, its residents do not rely on accessibility to drivers in order to conduct daily activities. As seen in Figure 3-8, clearly the share of NYC very-low income households without a driver in the household is significantly higher, as compared to very-low income households from all other NYS regions. Figure 3-8 also shows that the share of very-low income households without a driver dramatically dropped from year 2001 (50\% in Manhattan and 40\% in the rest of NYC) to year 2009 (under 28\%) in NYC. Outside of NYC, the shares of very-low income households without a driver in the NYS are very similar to their counterparts from the rest of U.S. 


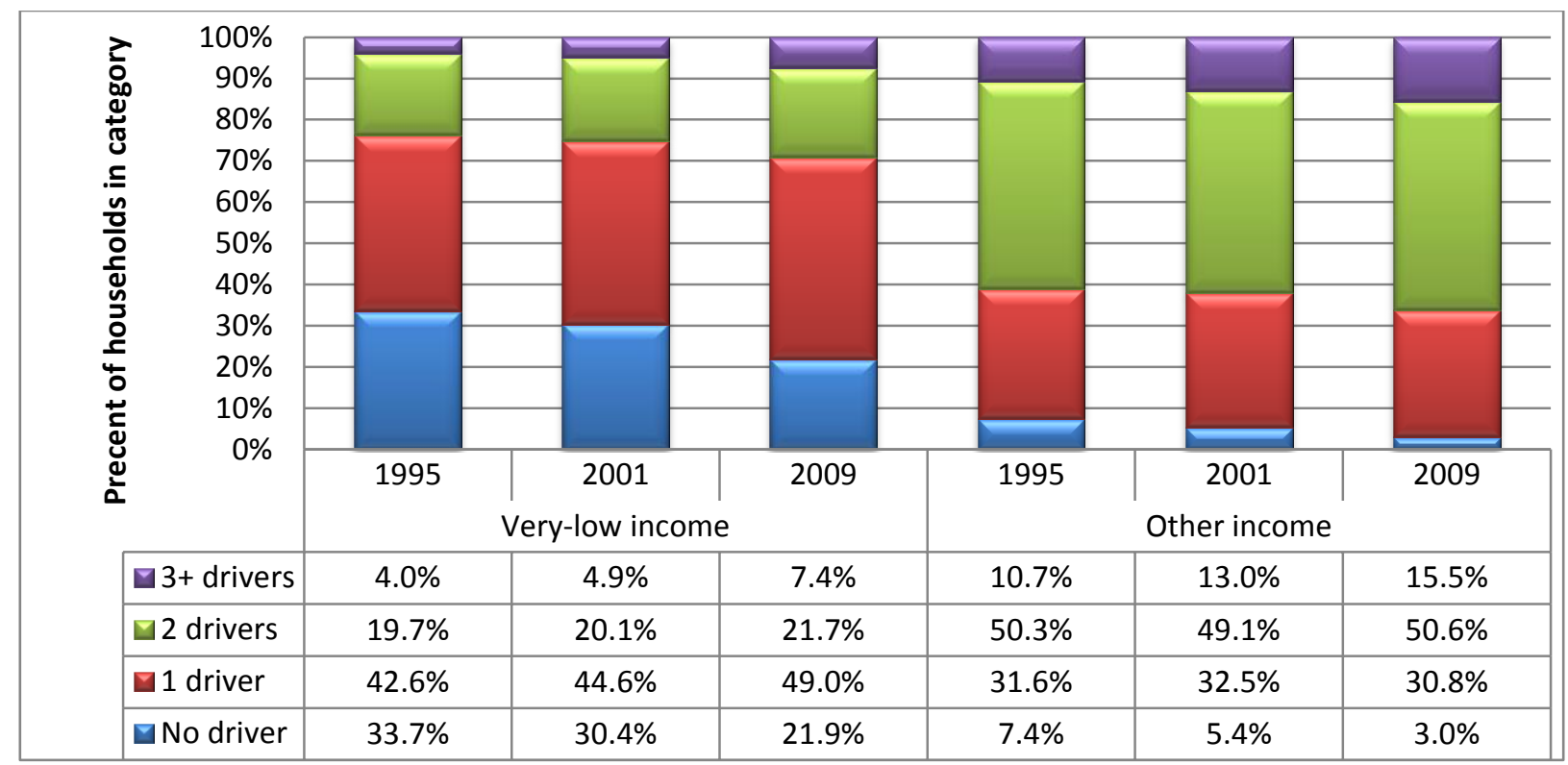

Figure 3-7. Distribution of households by number of drivers and income status for NYS (NHTS data)

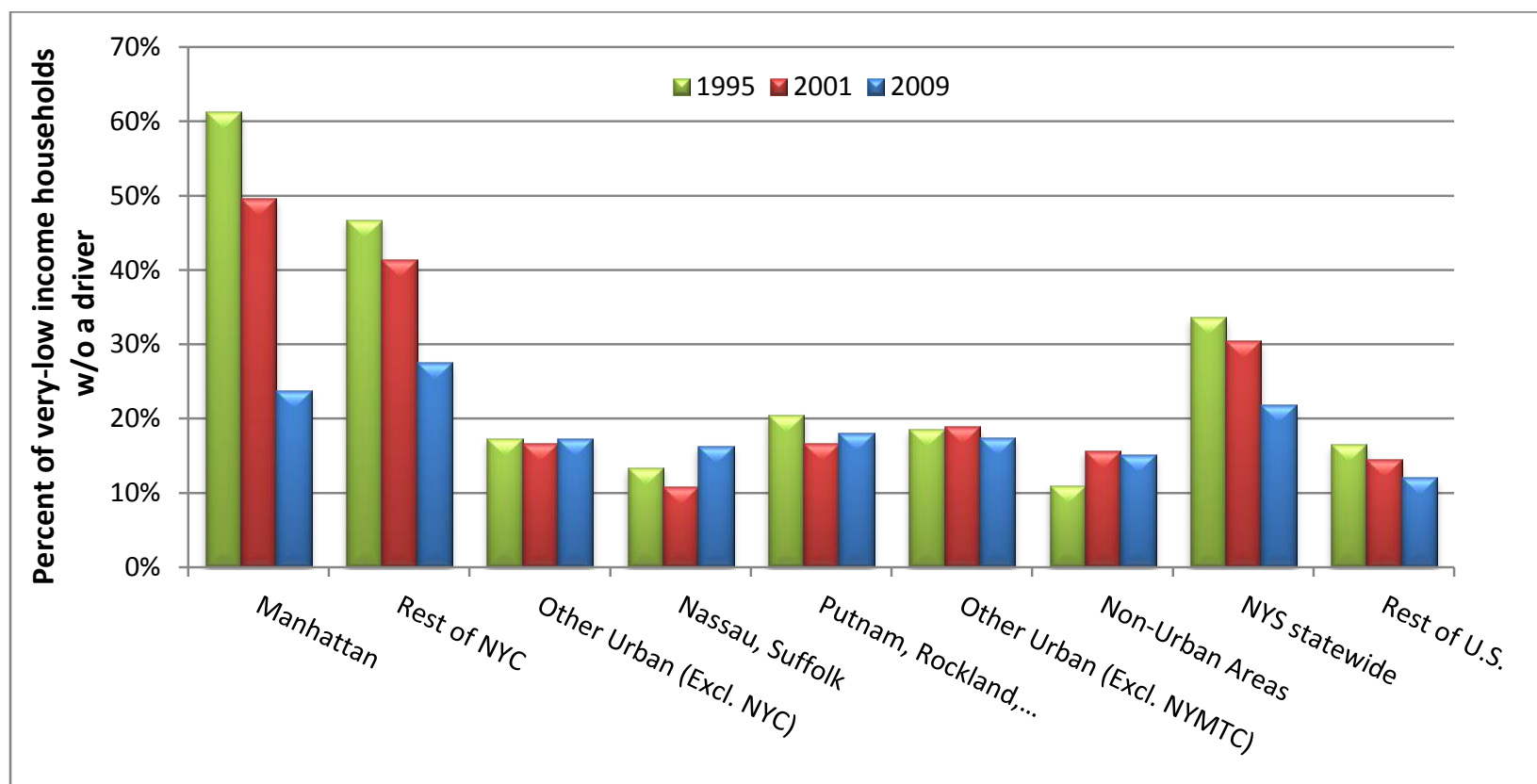

Figure 3-8. Percent of very-low income households without a driver by region (NHTS data)

Shares of households without drivers among the other income households, on the other hand, are significantly lower in all regions, including those that lived outside of NYS. Figure 3-9 shows that in 2009 only about $5 \%$ of other income households from the rest of the NYC area have no drivers within their households (top chart), versus about $28 \%$ of their counterpart verylow income household neighbors in 2009 (bottom chart of Figure 3-9). Overall, less than 2\% of the all other-income households from outside of NYC, or in the rest of the U.S., are without drivers in 2009. 


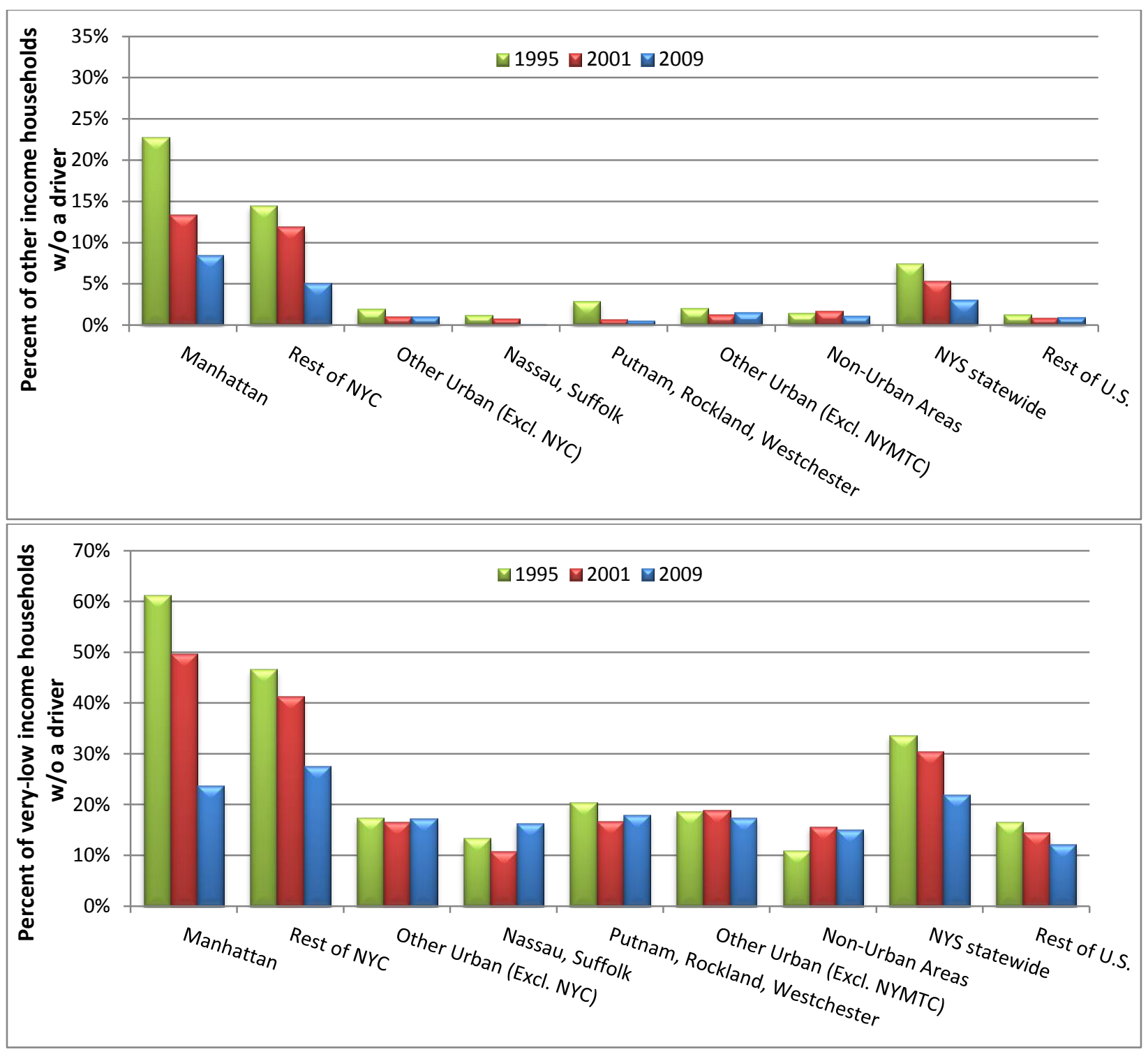

Figure 3-9. Percent of other income households (top chart) without a driver compared to very-low income households (bottom chart) by region (NHTS data)

\subsubsection{Household Size}

Considering household size, a person from a very-low income household has a higher likelihood of living alone, when compared to his/her counterpart from a household with other levels of income. According to 2009 NHTS, nearly two in five (39\%) of NYS very-low income households consist of only one person, while single-person households only account for $24 \%$ among other income households in NYS (Figure 3-10). The share of single occupant otherincome households remains the same over the years from 2001 to 2009 . However, there is roughly a $10 \%$ increase in the share of single occupant very-low income households, from $35 \%$ in 2001 to $39 \%$ in 2009 . 


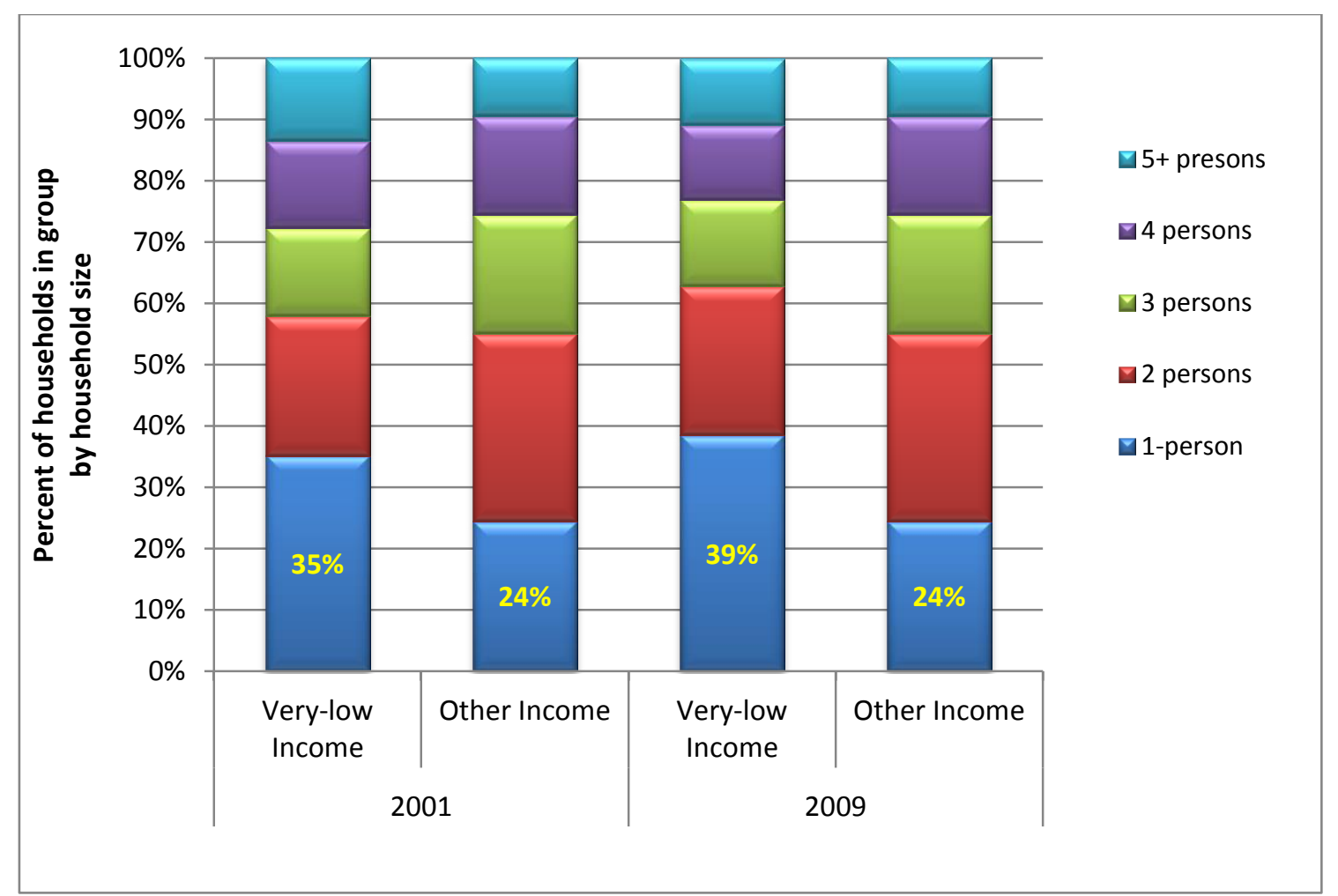

Figure 3-10. Percent of NYS households by household size and income group

\subsubsection{Vehicle Ownership}

A similar examination on vehicle ownership also shows that the very-low income NYS households have a higher likelihood of being a zero-vehicle household than their other-income household neighbors. As seen in Figure 3-11, nearly half of the very-low income households in NYS owned zero vehicles in 2009, with a similar pattern in 2001 and 1995. On the other hand, only about one in six of their other income neighbors were zero-vehicle households. Clearly visible from Figure 3-11, the changes in the shares of zero-vehicle households across NHTS years are not significant.

Income status also affects vehicle ownership for households residing in the rest of U.S., as displayed in Figure 3-12. Nearly 20\% of very-low income households outside of NYS owned zero vehicles, as compared to less than $2 \%$ of their other income household neighbors. Note that, as pointed out previously, the widely accessible public transit systems in NYC lessen driving needs, thus increasing the likelihood of not owning a vehicle among NYC households. With over half of the total NYS population living in the NYC area, its impact to the overall zerovehicle household share in NYS is evident. As shown in Figure 3-12, changes in the shares of zero-vehicle households between years 2001 and 2009 are not significant. 


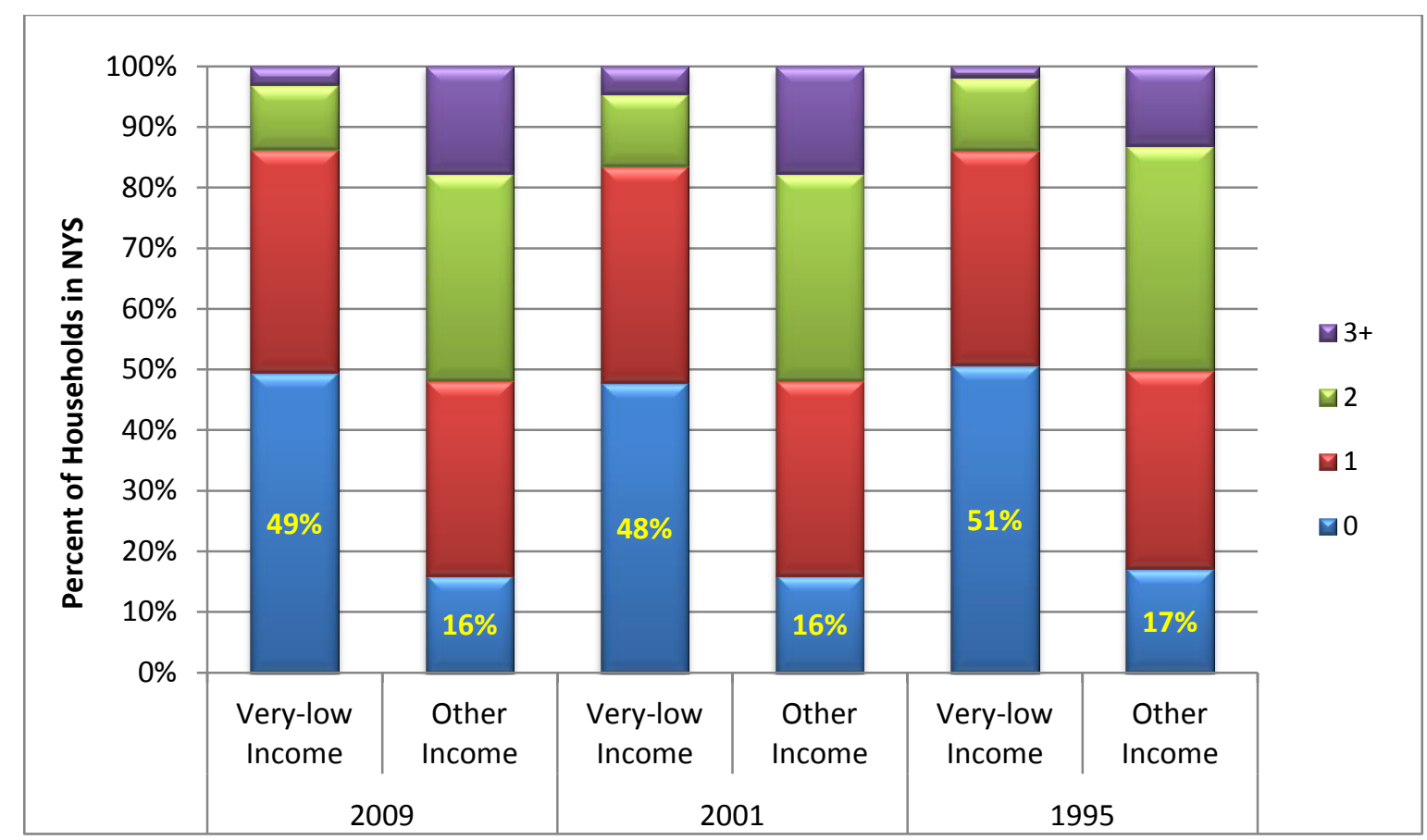

Figure 3-11. Distributions of NYS households by vehicle ownership and income status

\begin{tabular}{|c|c|c|c|c|c|c|c|c|c|}
\hline \multirow{17}{*}{ 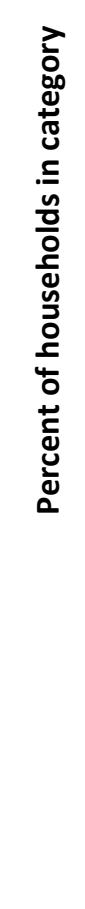 } & \multicolumn{9}{|c|}{$\begin{array}{r}100 \% \\
90 \%\end{array}$} \\
\hline & \multirow{2}{*}{\multicolumn{9}{|c|}{$80 \%$}} \\
\hline & & & & & & & & & \\
\hline & \multicolumn{9}{|l|}{$\begin{array}{l}10 \% \\
60 \%\end{array}$} \\
\hline & \multicolumn{9}{|l|}{$50 \%$} \\
\hline & \multirow{2}{*}{\multicolumn{9}{|c|}{$40 \%$}} \\
\hline & \multirow{2}{*}{\multicolumn{7}{|c|}{$\begin{array}{l}30 \% \\
20 \%\end{array}$}} & & \\
\hline & & & & & & & & & \\
\hline & \multicolumn{9}{|l|}{$10 \%$} \\
\hline & & $\begin{array}{l}\text { Very-low } \\
\text { Income }\end{array}$ & $\begin{array}{l}\text { Other } \\
\text { Income }\end{array}$ & $\begin{array}{l}\text { Very-low } \\
\text { Income }\end{array}$ & $\begin{array}{l}\text { Other } \\
\text { Income }\end{array}$ & $\begin{array}{l}\text { Very-low } \\
\text { Income }\end{array}$ & $\begin{array}{l}\text { Other } \\
\text { Income }\end{array}$ & $\begin{array}{l}\text { Very-low } \\
\text { Income }\end{array}$ & $\begin{array}{l}\text { Other } \\
\text { Income }\end{array}$ \\
\hline & & \multicolumn{2}{|c|}{ NYS } & \multicolumn{2}{|c|}{ Rest of U.S. } & \multicolumn{2}{|c|}{ NYS } & \multicolumn{2}{|c|}{ Rest of U.S. } \\
\hline & & \multicolumn{4}{|c|}{2001} & \multicolumn{4}{|c|}{2009} \\
\hline & $\nabla 4+$ & $1.1 \%$ & $5.3 \%$ & $3.4 \%$ & $10.6 \%$ & $0.6 \%$ & $5.3 \%$ & $3.0 \%$ & $10.6 \%$ \\
\hline & $\nabla 3$ & $3.4 \%$ & $12.4 \%$ & $7.1 \%$ & $18.6 \%$ & $2.4 \%$ & $12.4 \%$ & $6.0 \%$ & $18.6 \%$ \\
\hline & $\square 2$ & $12.0 \%$ & $34.1 \%$ & $22.9 \%$ & $43.4 \%$ & $10.6 \%$ & $34.1 \%$ & $22.4 \%$ & $43.4 \%$ \\
\hline & 回 & $35.6 \%$ & $32.2 \%$ & $46.3 \%$ & $25.7 \%$ & $36.9 \%$ & $32.2 \%$ & $49.0 \%$ & $25.7 \%$ \\
\hline & $\nabla 0$ & $47.9 \%$ & $16.0 \%$ & $20.3 \%$ & $1.7 \%$ & $49.5 \%$ & $16.0 \%$ & $19.5 \%$ & $1.7 \%$ \\
\hline
\end{tabular}

Figure 3-12. Distribution comparison of NYS to the rest of the U.S. households by vehicle ownership and income status (NHTS)

Furthermore, based on 2009 NHTS data, Figure 3-13 illustrates the relationship between the likelihood of being a zero-vehicle household and household income category. The likelihood of being a zero-vehicle household declined as the household income increases, which is true for 
households in all regions. Clearly, the likelihood of being a zero-vehicle household in NYC is significantly higher than areas outside of NYC, regardless of income level for household-a wellknown fact that was pointed out above and in other related studies ${ }^{13}$. As Figure 3-13 shows, shares of zero-vehicle households with income less than $\$ 25,000$ are significantly higher than those with income of $\$ 25,000$ or more, regardless of where the household resides. Note that, among households that did not report their income level, about $60 \%$ of those that lived in NYC did not own a vehicle in 2009 , while it was only about $12 \%$ of those that lived outside the NYC area.

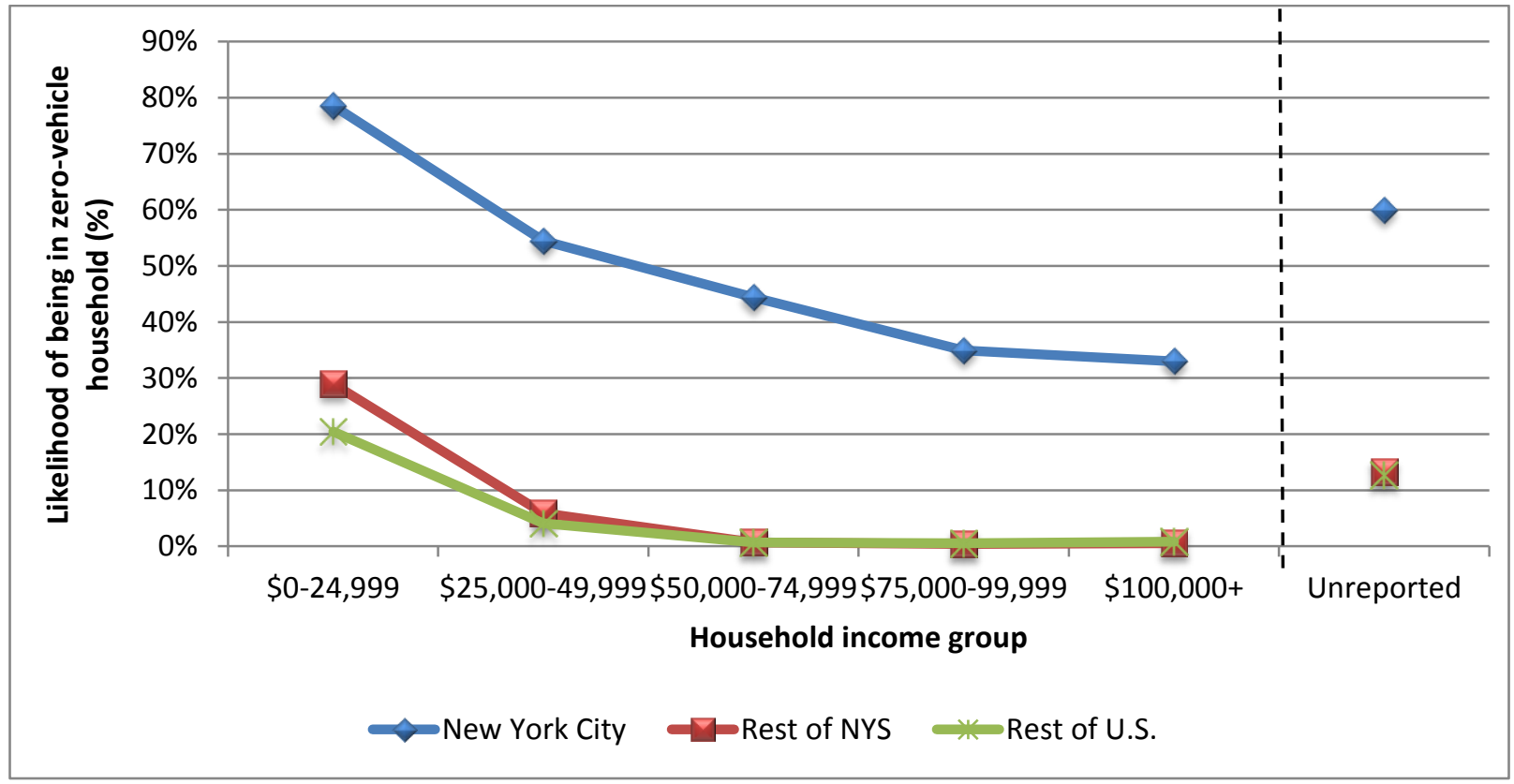

Figure 3-13. Likelihood of being a zero-vehicle household by income category and region (2009 NHTS data)

\subsubsection{Relationship between Number of Drivers and Vehicle Ownership}

When considering the number of drivers in a household against the number of vehicles owned, the majority of NYS's households have equal numbers of drivers and vehicles, regardless of the income status they have (see Figure 3-14). In 2009, 55\% of NYS households in both income categories had the same number of drivers as the number of vehicles they owned. However, as displayed in Figure 3-14, very-low income NYS households are less likely (under $4 \%$ ) to own more vehicles than the number of drivers of corresponding households. Over $12 \%$ of their other income household neighbors, on the other hand, owned more vehicles than the number of drivers in respective households during 2009. This is consistent with what was identified in Section 3.3.4; typically, a very-low income household owns fewer vehicles than its other income neighbor does.

\footnotetext{
${ }^{13}$ Cite other NYS special population reports here...
} 


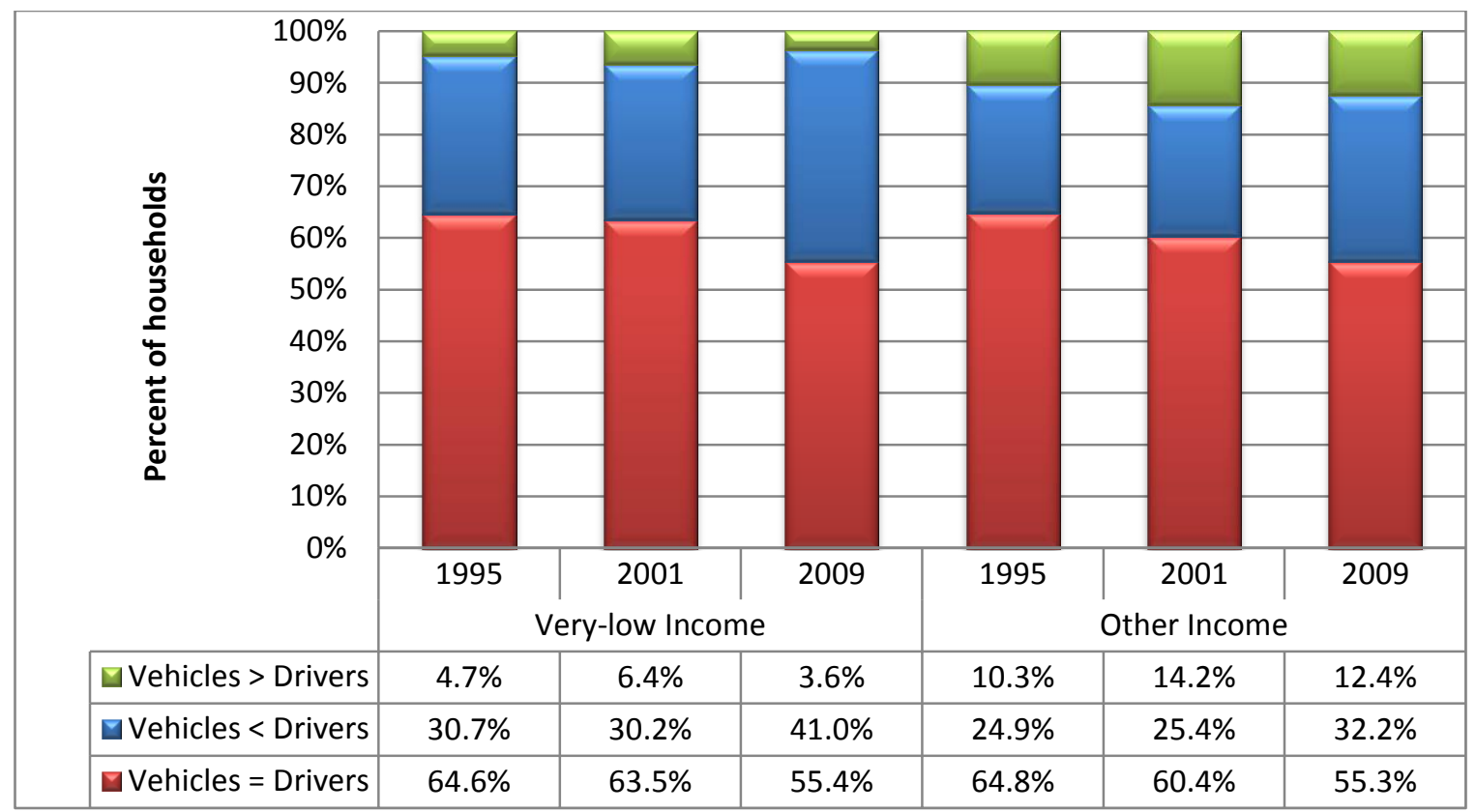

Figure 3-14. Distribution of NYS households by number of vehicle with respect to number of drivers, and income status (NHTS data)

\subsubsection{Vehicle Age}

On average, vehicles owned by a typical very-low income household in NYS are about twoyears older than vehicles owned by a household in the other income levels for 2009. Figure 3-15 shows that vehicles owned by a very-low income household in NYS for 2009, on average, was 9.6-years old, as compared to an average of 7.5-years old for a vehicle owned by a typical other income NYS household in the same year. The changes in average vehicle age over the three NHTS years were not significant in either household-income categories.

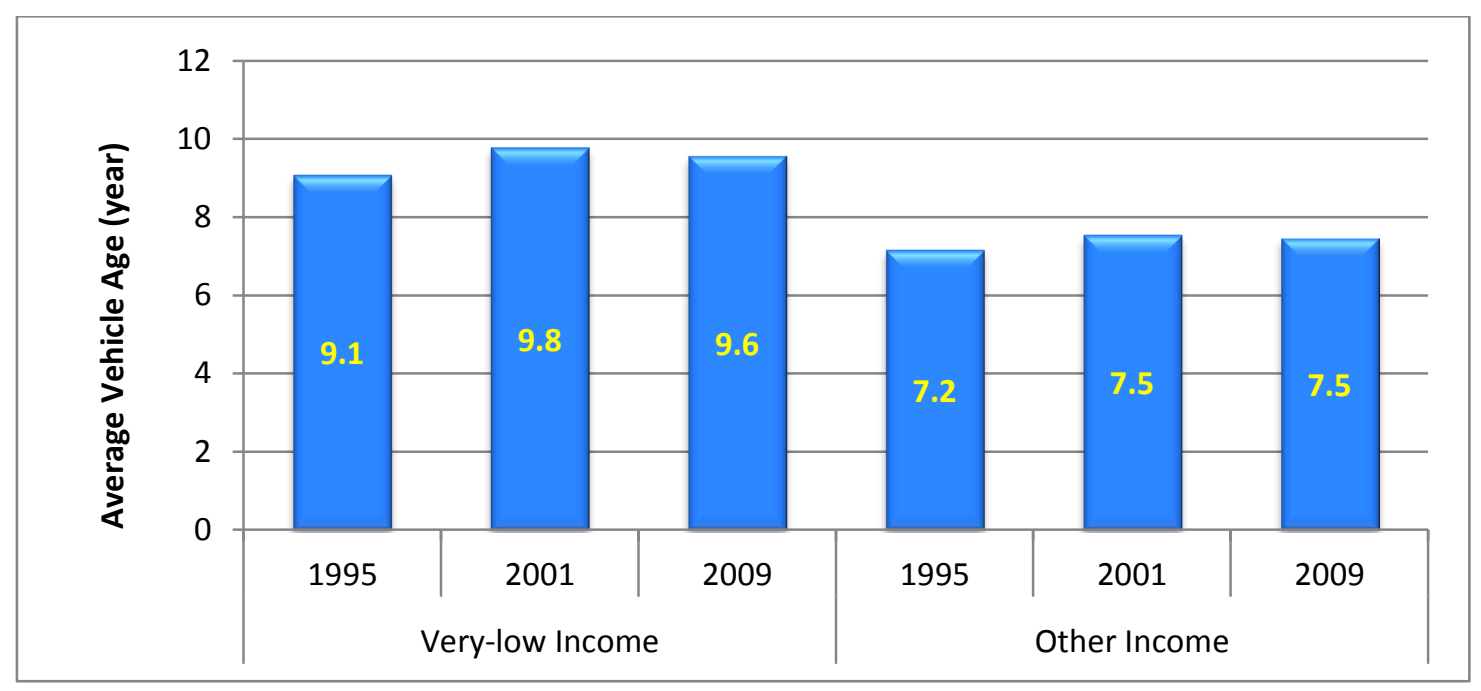

Figure 3-15. Average NYS resident's vehicle age by income status over the NHTS years 


\subsubsection{Worker Status}

People from a very-low income household have a lower likelihood of being employed ${ }^{14}$, as compared to their counterparts from other income households, regardless of where they lived. As seen in Figure 3-16, where red and blue bars represent very-low income households, and purple and green represent other income households, the differences between the two incomegroups' percentages of population being employed are significant. Using the Rest of NYC (i.e., outside Manhattan) as an example, while less than $37 \%$ of the population from very-low-income households lived in this region in 2009 were workers, nearly $60 \%$ of their other income household neighbors were employed during the same time. As a whole, shares of the employed population for NYS are similar to those of the Rest of U.S. No significant differences in the rates of being a worker for other income persons between 2001 and 2009 are observed in Figure $3-16$, although there is a slight decline in most regions among the very-low income populations over the eight years.

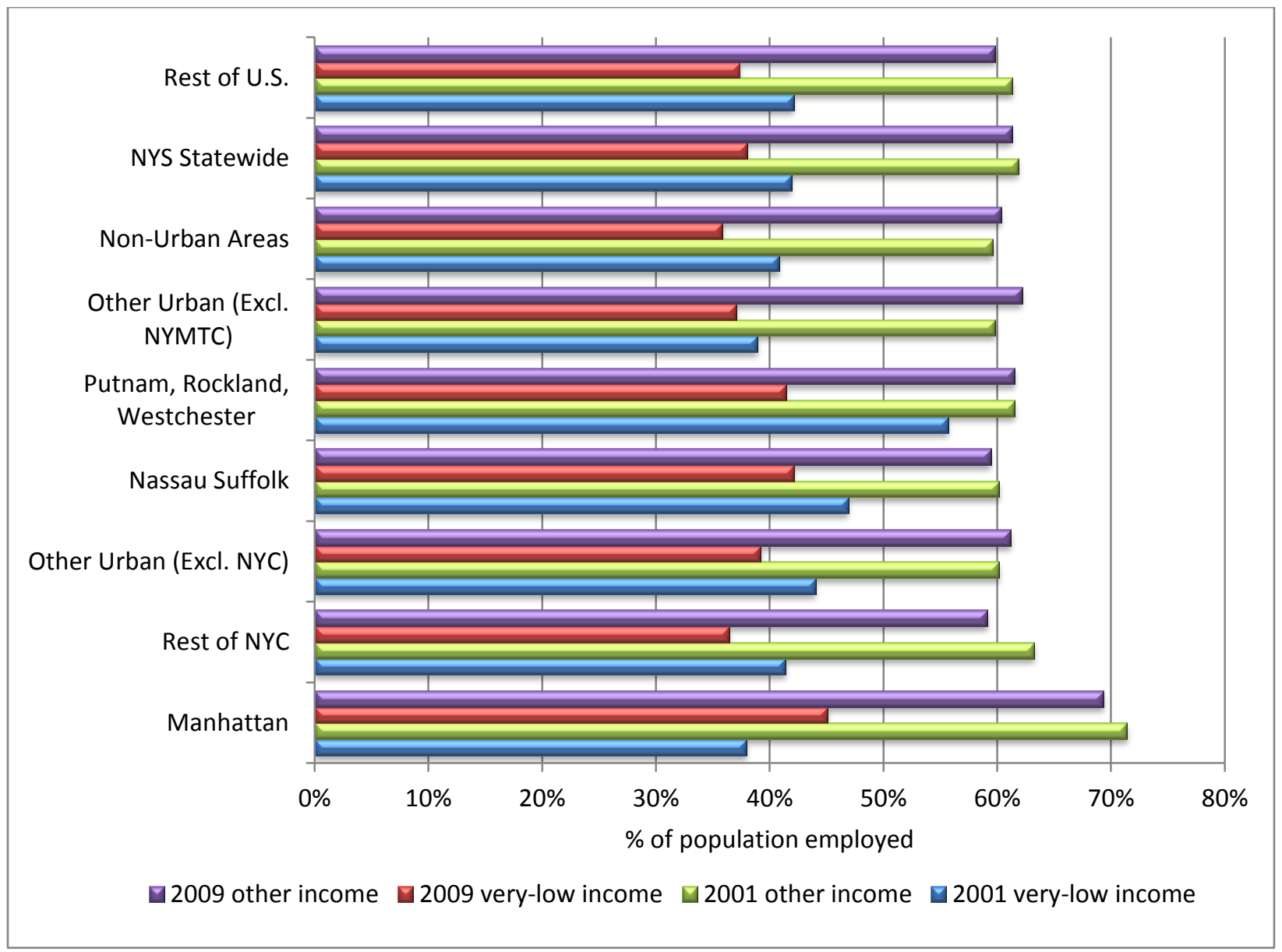

Figure 3-16. Percent of population employed by income status (2001 and 2009 NHTS)

\footnotetext{
14 "being employed" represents workers with full-time, part-time, and multiple jobs.
} 


\subsubsection{Life Cycle}

Table 3-2 shows that the share of very-low income households in NYS was increased from $29 \%$ in 2001 to 32\% in 2009. As shown in Table 3-2, households with two or more adults and no children (i.e., "2+ Adults, no children" category) accounted for a significantly higher share (around a quarter of the households) among those with other income in all three NHTS years versus only $10-13 \%$ for their counterparts with very-low income. On the other hand, over one in five $(21 \%)$ very-low income NYS households were retired single-occupant households (i.e., "1 Adult, Retired, No children" category) in 2009, while the share was only $6 \%$ for their counterpart other income households for the same year.

Table 3-2. New York State household distribution by life-cycle category and income status in 2009, 2001, and 1995 (NHTS data)

\begin{tabular}{|c|c|c|c|c|c|c|}
\hline \multirow{4}{*}{$\begin{array}{l}\text { Life Cycle Category of } \\
\text { Households in NYS }\end{array}$} & \multicolumn{2}{|c|}{2009 NHTS } & \multicolumn{2}{|c|}{2001 NHTS } & \multicolumn{2}{|c|}{1995 NPTS } \\
\hline & $\begin{array}{l}\text { Very-low } \\
\text { income }\end{array}$ & $\begin{array}{l}\text { Other } \\
\text { income }\end{array}$ & $\begin{array}{c}\text { Very-low } \\
\text { income }\end{array}$ & $\begin{array}{l}\text { Other } \\
\text { income }\end{array}$ & $\begin{array}{l}\text { Very-low } \\
\text { income }\end{array}$ & $\begin{array}{l}\text { Other } \\
\text { income }\end{array}$ \\
\hline & $2,090,123$ & $4,422,623$ & $1,855,134$ & $4,589,699$ & $1,242,461$ & $3,693,820$ \\
\hline & $32 \%$ & $68 \%$ & $29 \%$ & $71 \%$ & $25 \%$ & $75 \%$ \\
\hline 1 Adult, No Children & $17.5 \%$ & $18.8 \%$ & $16.3 \%$ & $18.1 \%$ & $17.6 \%$ & $18.7 \%$ \\
\hline 2+ Adults, No Children & $10.2 \%$ & $24.3 \%$ & $12.9 \%$ & $23.0 \%$ & $13.0 \%$ & $25.7 \%$ \\
\hline 1 Adult, Youngest 0-5 & $1.8 \%$ & $0.5 \%$ & $6.6 \%$ & $0.7 \%$ & $9.3 \%$ & $0.8 \%$ \\
\hline $2+$ Adults, Youngest $0-5$ & $10.9 \%$ & $9.9 \%$ & $12.5 \%$ & $14.8 \%$ & $13.3 \%$ & $16.5 \%$ \\
\hline 1 Adult, Youngest 6-15 & $5.4 \%$ & $1.2 \%$ & $6.2 \%$ & $2.2 \%$ & $7.0 \%$ & $2.4 \%$ \\
\hline 2+ Adults, Youngest 6-15 & $10.5 \%$ & $15.0 \%$ & $9.8 \%$ & $15.3 \%$ & $10.6 \%$ & $15.9 \%$ \\
\hline 1 Adult, Youngest 16-21 & $2.3 \%$ & $1.1 \%$ & $1.5 \%$ & $1.0 \%$ & $1.6 \%$ & $0.6 \%$ \\
\hline 2+ Adults, Youngest 16-21 & $3.0 \%$ & $\mathbf{7 . 0 \%}$ & $4.1 \%$ & $5.2 \%$ & $3.4 \%$ & $4.1 \%$ \\
\hline 1 Adult, Retired, No Children & $21.0 \%$ & $6.0 \%$ & $18.8 \%$ & $6.0 \%$ & $14.2 \%$ & $4.9 \%$ \\
\hline $\begin{array}{l}2+\text { Adults, Retired, No } \\
\text { Children }\end{array}$ & $17.3 \%$ & $16.2 \%$ & $11.2 \%$ & $13.4 \%$ & $10.1 \%$ & $10.4 \%$ \\
\hline Unreported & & & $0.3 \%$ & $0.3 \%$ & & \\
\hline ALL & $100 \%$ & $100 \%$ & $100 \%$ & $100 \%$ & $100 \%$ & $100 \%$ \\
\hline
\end{tabular}

Note: yellow-shaded cell indicates estimates based on small sample size. The bolded cells represent cells with statistically significant differences between the two income categories within the same year.

Instead of the ten categories used in Table 3-2, Figure 3-17 displays an aggregated fourgroup life-cycle distribution of NYS households. In 2009, regardless of the number of adults in a household, the combined "retired without children" category (shown in purple bars in Figure $3-17$ ) accounts for over $38 \%$ of NYS's very-low income households as compared to only about $22 \%$ for the other income households. Moreover, the share of "Adults without children" among the other income NYS households is about 50\% higher than that of the very-low income NYS households, i.e., $43 \%$ versus $28 \%$, respectively. 


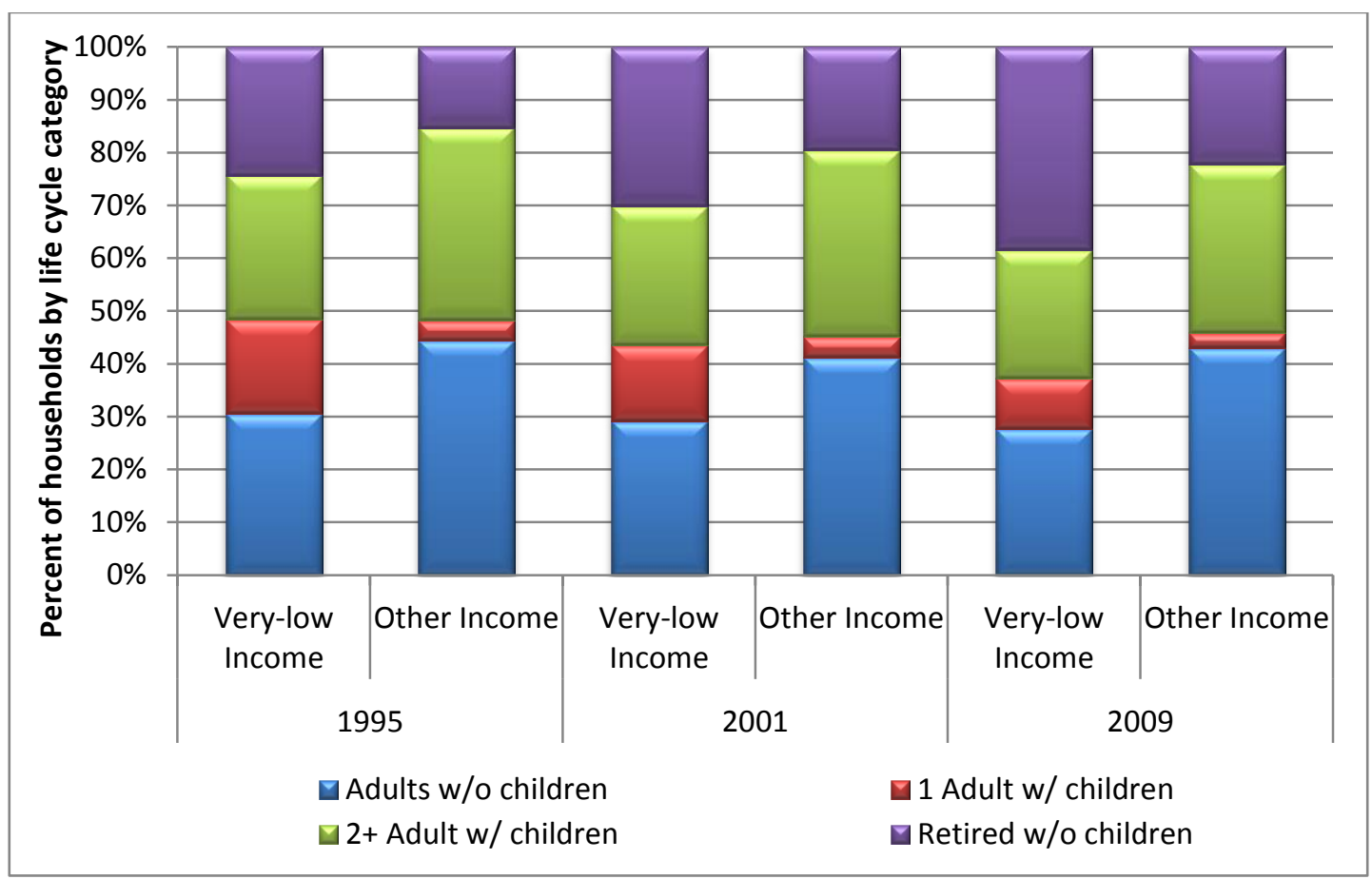

Figure 3-17. Distribution of NYS households by life cycle category (NHTS)

\subsection{ZERO-VEHICLE VERY-LOW INCOME HOUSEHOLDS}

\subsubsection{Geographic Distribution of Zero-Vehicle Very-Low Income Households}

Nearly three in five (59\%) very-low income NYS households that own zero-vehicles resided outside of Manhattan but inside the five-county NYC region. As shown in Figure 3-18, about three-quarters (i.e., $59.2 \%+14.4 \%$ ) of NYS's very-low income households that owned no vehicles were from NYC. Considering that NYC is where nearly $60 \%$ of NYS's population resides, the heavy concentration of very-low-income-without-vehicle population in NYC might be attributed to the readily available public transit and prospective job markets in that region. Only $4 \%$ of very-low income households without any vehicles lived in rural areas of NYS during 2009.

A household without a vehicle is predominantly due to the household being unable to afford one. As mentioned previously, the widely available public transit in the NYC area certainly has an impact on vehicle ownership for its residents, especially among the very-low income households. According to 2009 NHTS data, Figure 3-19 shows that 93\% of very-low income households in Manhattan owned no vehicles, while 70\% of very-low income NYC households outside Manhattan were zero-vehicle households during the same year. On the other hand, only 19\% of very-low-income households in Nassau/Suffolk area owned zero vehicles in 2009. There is no significant change in the shares of zero-vehicle households among very-low income households from 2001. 


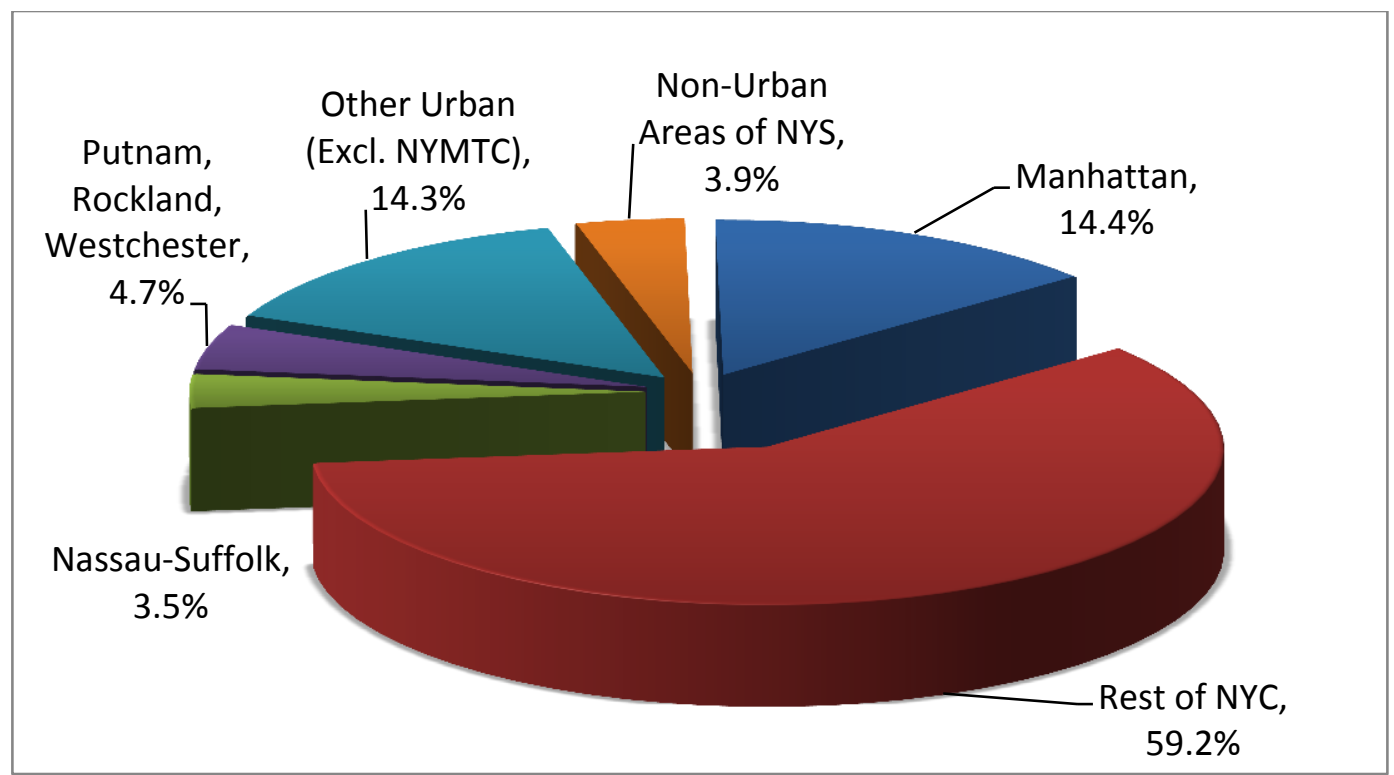

Figure 3-18. Distribution of zero-vehicle very-low income households in NYS (2009 NHTS)

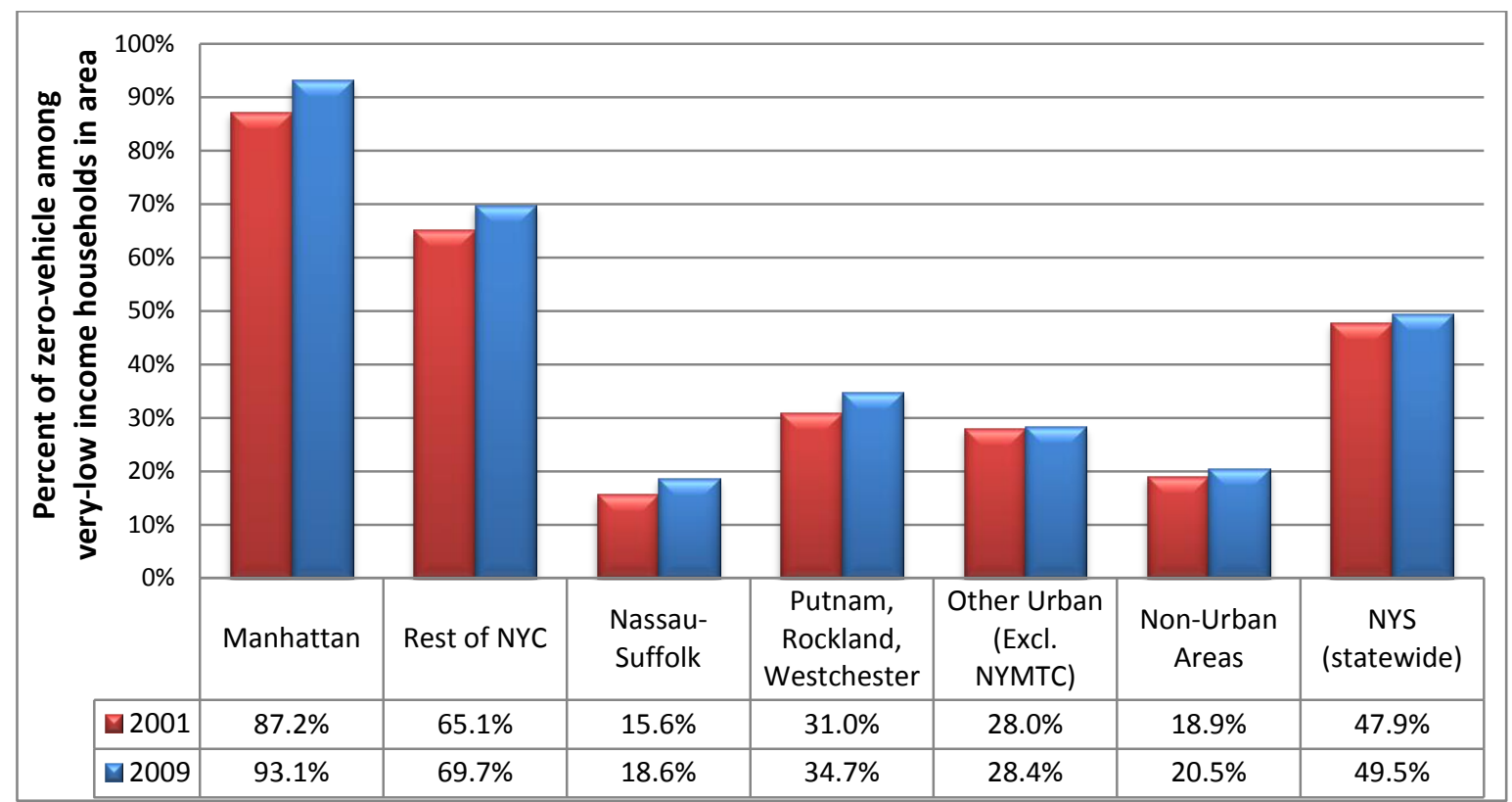

Figure 3-19. Share of zero-vehicle households among very-low income households by region for 2001 and 2009 (NHTS data)

\subsubsection{Share of Very-Low Income among Households Owning Zero-Vehicles}

Examining the share from another angle, less than $30 \%$ of Manhattan households that owned zero-vehicles in 2009 were indeed from a very-low income household (see Figure 3-20). This is consistent with the consensus that many residents of Manhattan choose to live without any vehicles (i.e., not because of income limitations). On the other hand, nearly $82 \%$ of zero-vehicle households from Nassau/Suffolk area, and about 93\% in Putnam/Rockland/Westchester region, 
belong to the very-low-income category in 2009. That is, outside of Manhattan, NHTS data clearly demonstrated the existence of an association between affordability of a vehicle and the very-low income status of a household. Note that further investigation on mobility patterns of individuals from NYS's very-low income and zero-vehicle households are discussed later in this report.

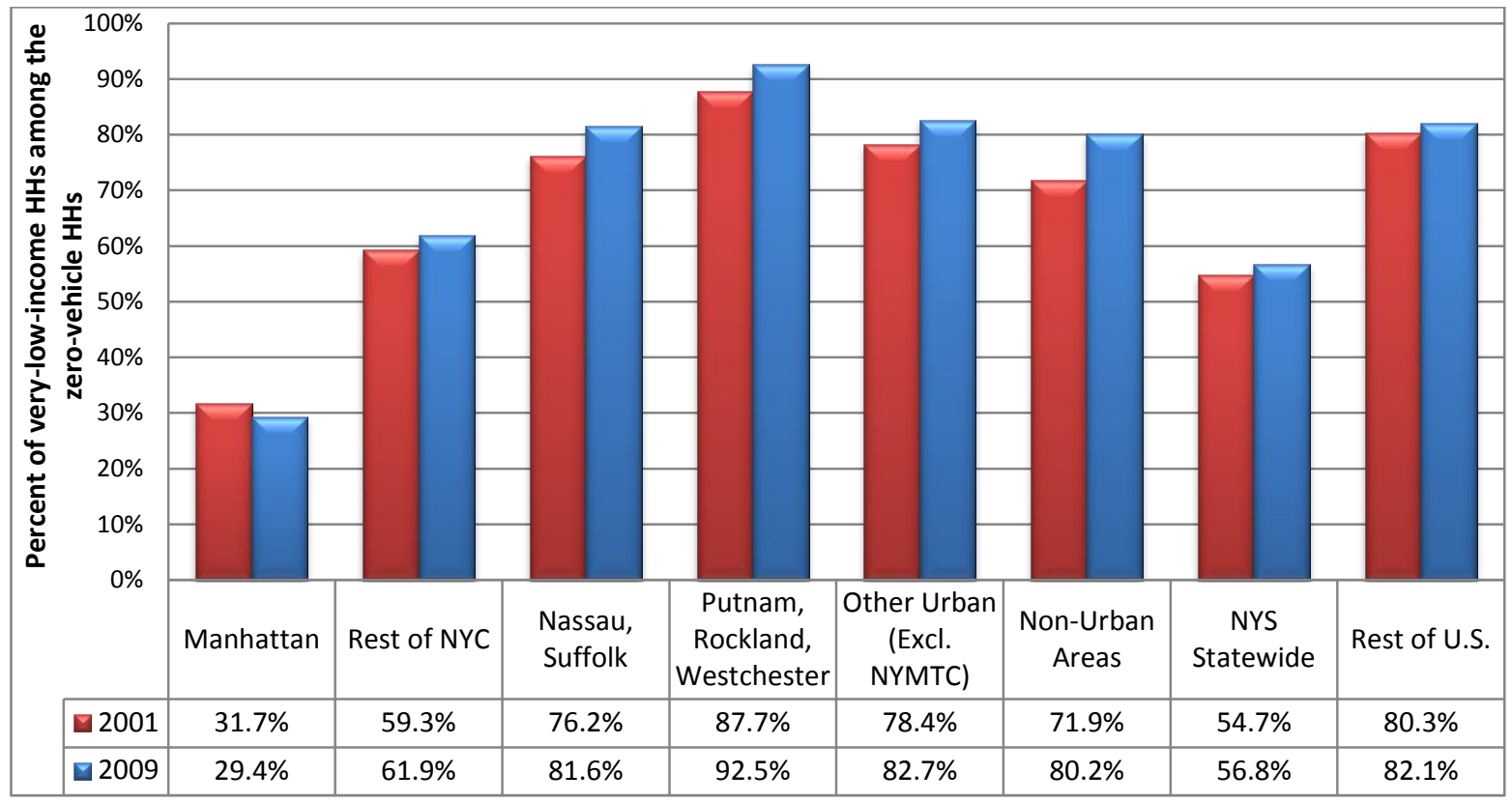

Figure 3-20. Share of very-low income households with zero-vehicles by household region (NHTS data) 



\section{MOBILITY OF LOW-INCOME HOUSEHOLDS}

\subsection{OVERVIEW OF LOW INCOME TRAVEL}

\subsubsection{Impact of Income on NYS Resident's Travel}

Using data collected under the NHTS, Table 4-1 summarizes the population sizes and the shares of persons who did not travel on their-assigned travel day during 1995, 2001, and 2009, by household income classifications. In 2009, about 17\% of NYS residents (ages of 5 years and older) from very-low income households did not travel compared to only $12 \%$ of their counterparts from other income households. The difference between these two non-travelingpopulation shares is statistically significant.

Note that a similar conclusion can also be drawn from both 2001 and 1995. The NHTS data shows that a person from a very-low income household has a significantly higher likelihood of not traveling on any given day (NHTS-assigned travel day), as compared to his/her counterparts from other income households. In addition, Table 4-1 shows that changes over time, in terms of the shares of the non-traveling population in NYS, were not statistically significant.

Table 4-1. Travel status for NYS residents by income status (2009, 2001, and 1995 NHTS data)

\begin{tabular}{|c|c|c|c|}
\hline NYS Residents & 2009 & 2001 & 1995 \\
\hline \multicolumn{4}{|c|}{ Total number of Persons } \\
\hline Very-low income & $5,240,993$ & $4,576,332$ & $3,391,832$ \\
\hline Other income & $11,868,063$ & $12,633,491$ & $10,277,902$ \\
\hline \multicolumn{4}{|c|}{ Number of persons did not travel on travel day } \\
\hline Very-low income & 896,091 & 804,116 & 597,340 \\
\hline Other income & $1,425,899$ & $1,486,112$ & $1,186,178$ \\
\hline \multicolumn{4}{|c|}{ Percent of persons did not travel on travel day } \\
\hline Very-low income & $17.1 \%$ & $17.6 \%$ & $17.6 \%$ \\
\hline Other income & $12.0 \%$ & $11.8 \%$ & $11.5 \%$ \\
\hline
\end{tabular}

Although the very-low income population merely accounted for a $31 \%$ share of all NYS residents (ages of 5 years and older) in 2009, the share of very-low income households goes up to nearly $40 \%$ for the non-traveling population only (i.e., those who did not travel on travel day). As displayed in Figure 4-1, the share of very-low income population is consistently higher $(\sim 10 \%)$ among the non-traveling group than that of traveling populations across all three NHTS years examined. Therefore, a non-traveling person is more likely to have resided in a very-low income household when compared to the rest of NYS populations. 


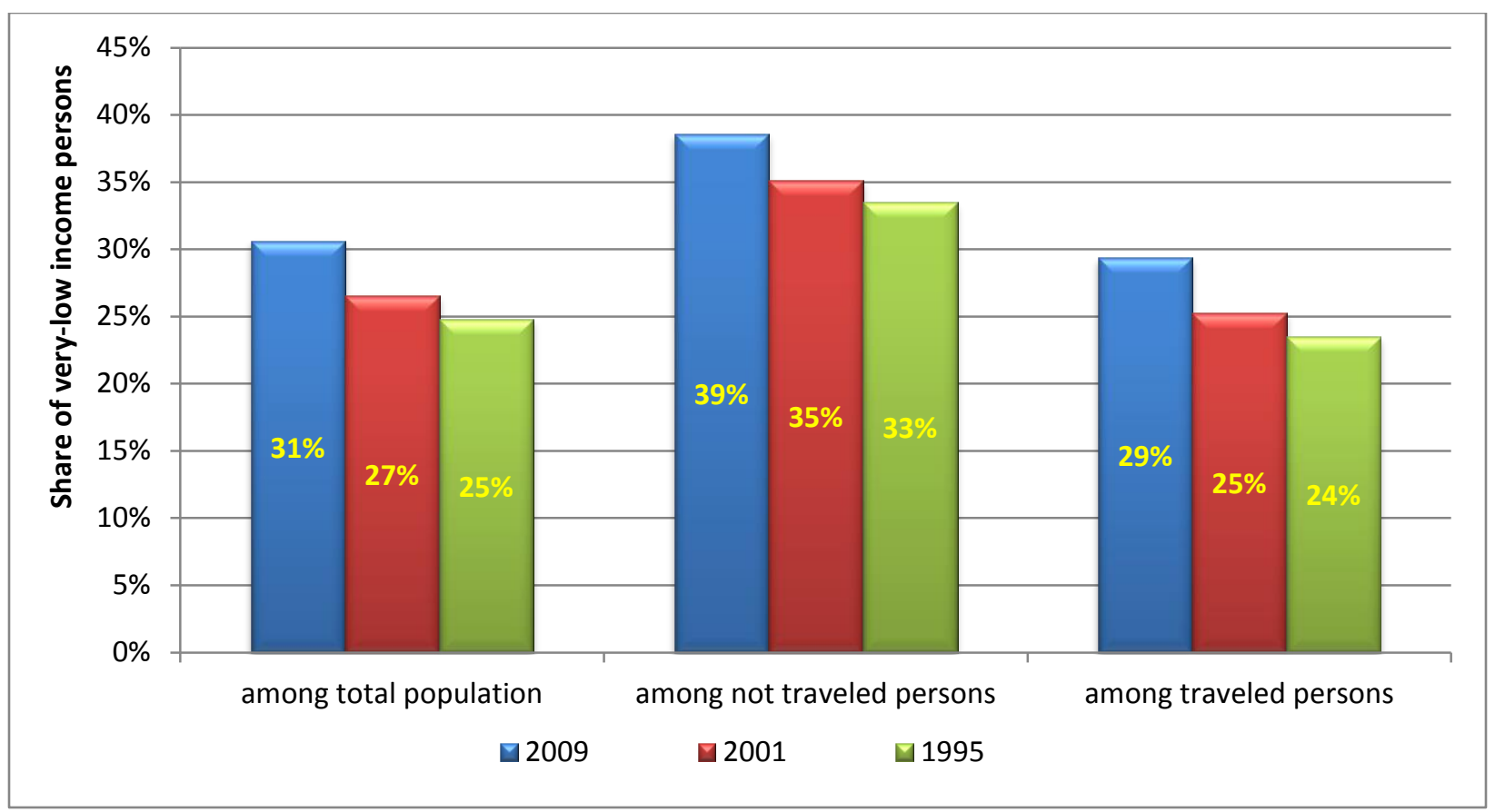

Figure 4-1. Share of very-low income population in NYS, by travel status on NHTS-assigned travel day (NHTS data)

\subsubsection{Impact of Income on Vehicle Travel}

Considering vehicle travel, Table 4-2 shows that 57\% of NYS drivers from very-low income households did not drive, but not necessarily meaning all of them used POV, on their NHTSassigned travel day during 2009. The share of drivers not driving on a given day is significantly lower $(37 \%)$ for the other income households during the same year. As seen in Table 4-2, a similar pattern as stated above, also exists in 2001 and 1995. That is, a very-low income NYS driver is less likely to drive on a given day as compared to his/her counterpart other income neighbor.

Unlike Table 4-1, where no changes over time were observed, the shares of very-low income drivers who did not drive on a travel day increased from $46 \%$ in 1995, to $49 \%$ in 2001, then to 57\% in 2009 (see Table 4-2). Between 2001 and 2009, the change in shares of very-low income drivers who did not drive on a travel day is statistically significant. However, no difference in shares was visible between 2001 and 1995.

As shown in Table 4-2, the shares of drivers who did not drive on a travel day are significantly lower among other income NYS residents, as compared to those of very-low income drivers for each corresponding year (with $31 \%$ in 1995, 32\% in 2001, and 37\% in 2009). Similarly, the difference in shares of other income drivers who did not drive on a travel day is statistically significant between 2001 and 2009, but not between 1995 and 2001 . 
Table 4-2. Travel status for NYS drivers by income status (2009, 2001, and 1995 NHTS data)

\begin{tabular}{|c|c|c|c|}
\hline NYS Residents & 2009 & 2001 & 1995 \\
\hline \multicolumn{4}{|c|}{ Total number of Drivers } \\
\hline Very-low income & $2,859,924$ & $1,833,428$ & $1,397,895$ \\
\hline Other income & $9,186,841$ & $8,514,340$ & $7,107,168$ \\
\hline \multicolumn{4}{|c|}{ Number of drivers did not drive on travel day } \\
\hline Very-low income & $1,627,778$ & 895,106 & 638,765 \\
\hline Other income & $3,390,798$ & $2,731,085$ & $2,193,013$ \\
\hline \multicolumn{4}{|c|}{ Percent of drivers did not drive on travel day } \\
\hline Very-low income & $56.9 \%$ & $48.8 \%$ & $45.7 \%$ \\
\hline Other income & $36.9 \%$ & $32.1 \%$ & $30.9 \%$ \\
\hline
\end{tabular}

As displayed in Figure 4-2, a driver that did not drive on a travel day has a significantly higher likelihood of being from a very-low income household in all three NHTS years. Specifically, among drivers not driving on their assigned travel day in 2009, nearly one-third (32\%) of those drivers came from a very-low-income household (Figure 4-2). The shares of drivers from a very-low income household among those who did drive on a travel day are much lower, at 13\%-18\% over the three NHTS years. This further confirms that income status has an impact on the mobility of NYS residents. Explicitly, NHTS data shows that mobility for people from very-low income households are more limited than that of their counterparts from other income households, regardless of how mobility was measured (i.e., focusing on drivers only or on all residents in NYS). Additional measures (e.g., trip rates and trip length) on mobility, income status and other travel characteristics are discussed in the rest of this Section.

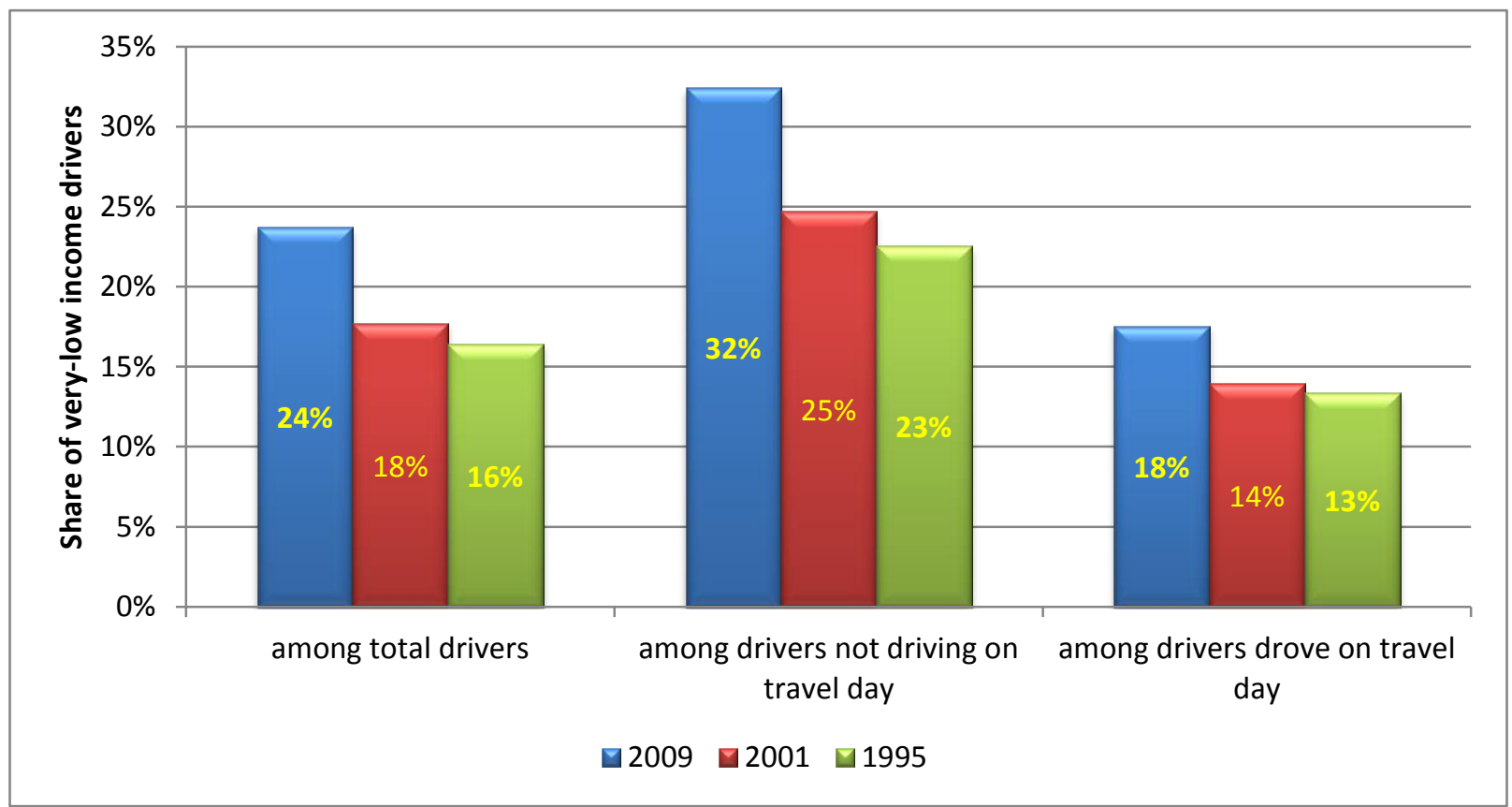

Figure 4-2. Share of very-low-income NYS residents drivers by travel status on NHTS-assigned travel day (NHTS data) 


\subsection{TRAVEL FREQUENCIES BY PERSON TRIP}

\subsubsection{Average Daily Person-Trip Rate}

Figure 4-3 presents the average number of person-trips per day by income status, region of residency, and year using NHTS data from 1995, 2001, and 2009. As seen in the figure, persons from very-low income households, on average, took fewer daily trips as compared to their counterparts from other income households. For example, while a NYS resident in the other income group traveled an average of 3.95 person-trips per day during 2009, his/her neighbor from a very-low income household made nearly $20 \%$ fewer daily trips, an average of 3.10 person-trips in the same year. The gap in person-trip rates between the two income groups is most visible for those who lived in NYC or other urban areas in NYS with 2,000+ in population density per square-mile. The very-low income population in NYC was about $25 \%$ less mobile (when measured by person-trip rates) than their counterpart other income population, with a daily average of 2.95 person-trips versus 3.91 person-trips, respectively (Figure 4-3). Similarly, the very-low income population from NYS's other most-dense urban areas traveled about $26 \%$ less frequently than their counterpart other income neighbors, with an average of 3.08 daily person-trips versus 4.16 daily person-trips, respectively.

Overall, there is no significant difference in the average daily person-trip rates between NYS and the rest of the U.S. A reduction in daily person trip rates over time (1995 to 2009), particularly among very-low income households, is also noticeable for most regions shown in Figure 4-3. Appendix B contains additional tables for daily person trips per person (Table B-5), daily vehicle trips per driver (Table B-6), and average vehicle trip length (Table B-7). 


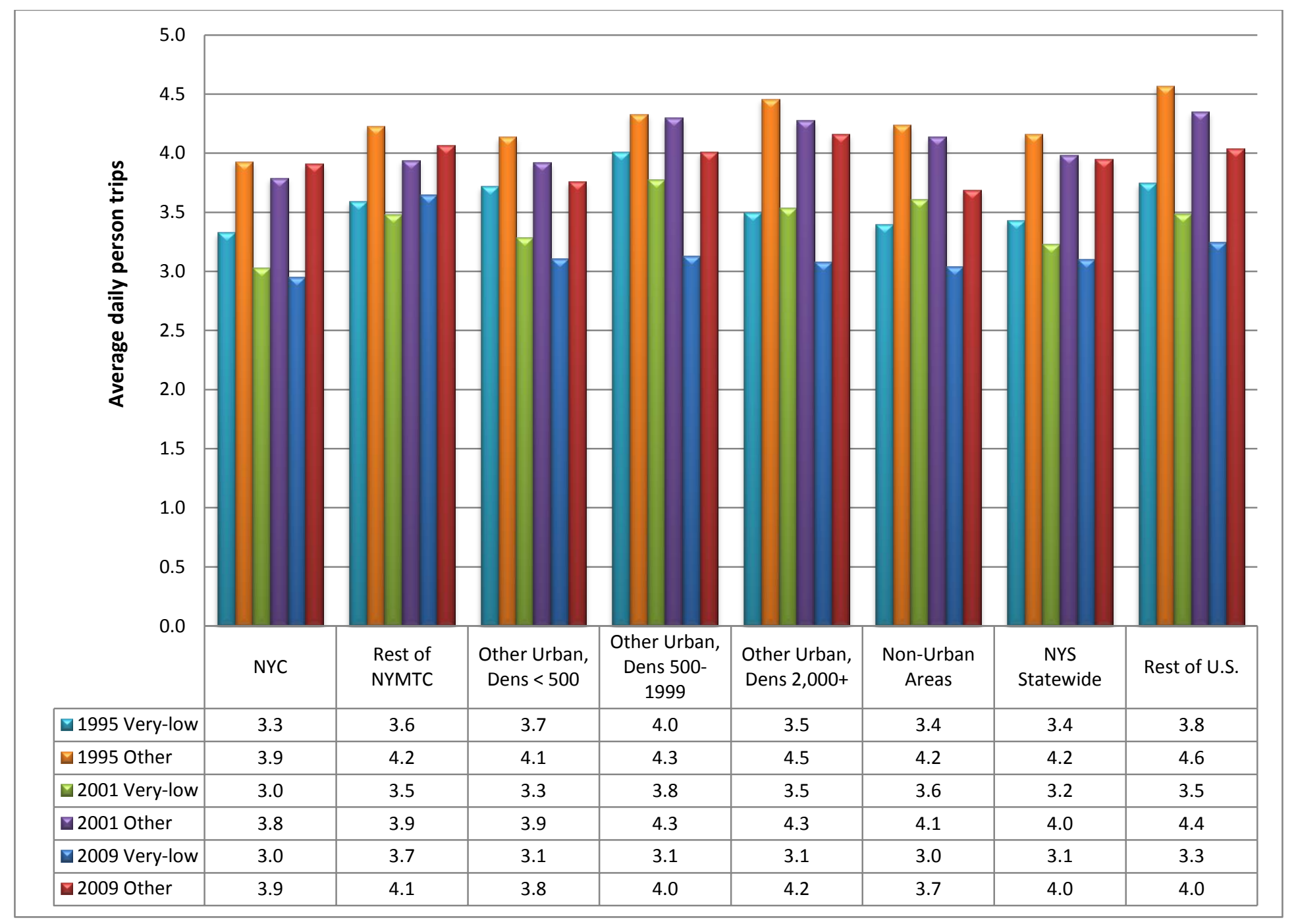

Figure 4-3. Average daily person trips by income status, region, and year (NHTS data) 


\subsubsection{Share of Daily Person-Trips by Purpose and Income}

Figure 4-4 presents person-trip distributions, by trip purpose and traveler's income status, for trips taken by NYS residents during the latest three NHTS years. People from NYS's very-low income households are more likely to travel for family and personal business, or school/church activities, but less likely to travel for work or social/recreational activities, when compared with their other income household neighbors. Specifically, less than $14 \%$ of person-trips taken by NYS's very-low income population in 2009 were for earning a living (i.e., work), while $20 \%$ of person-trips made by their other income counterparts accounted for work-trips during the same year. On the other hand, travel for "civic, educational and religious" activities accounted for nearly $14 \%$ of trips taken by very-low income persons in 2009 , while only $8 \%$ of trips made by other income population were for this same purpose.

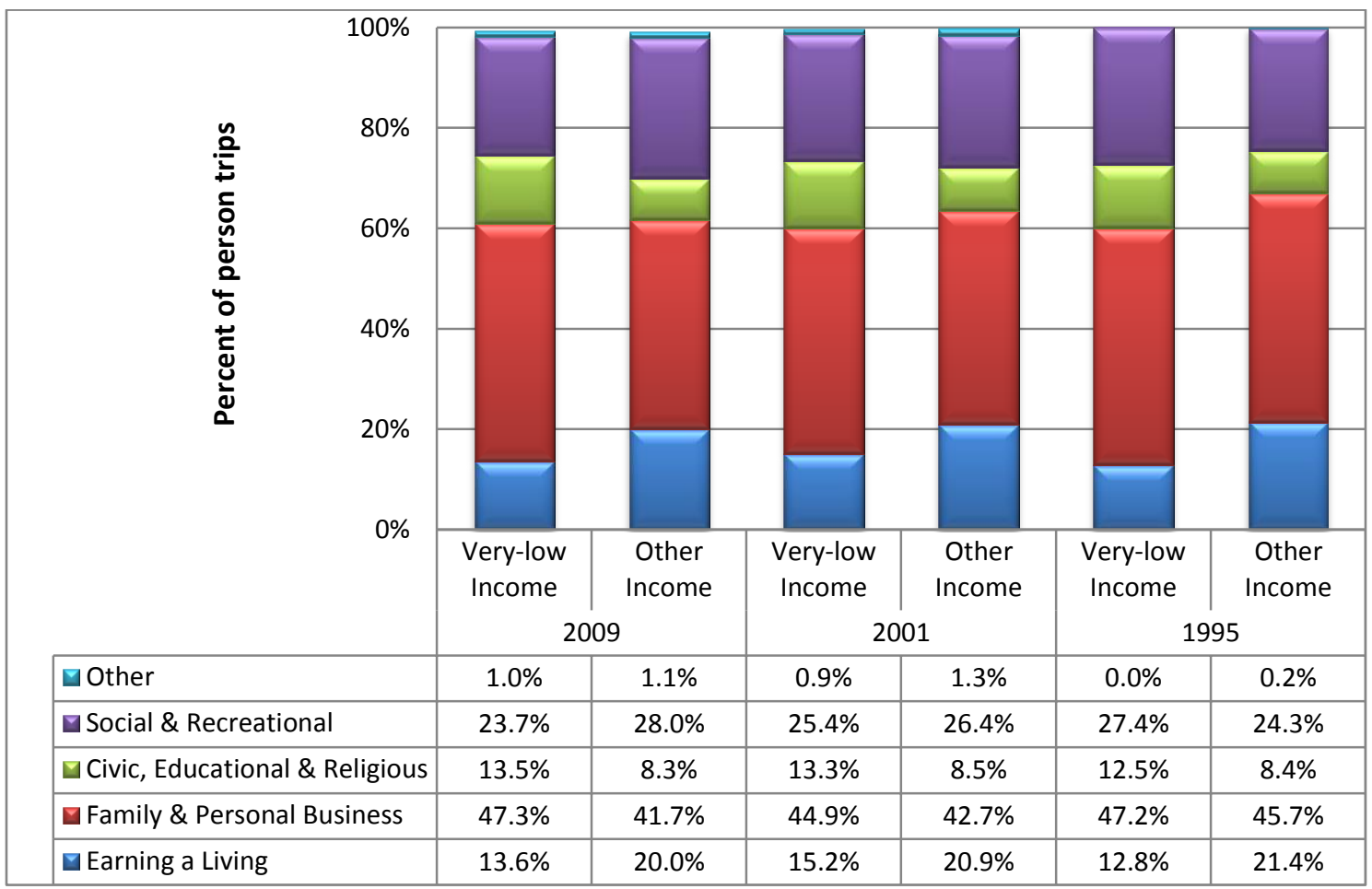

Figure 4-4. Distribution of person trips by trip purpose and income status (NHTS data)

Notice the distributions of person-trip by trip-purpose remains relatively stable over the three NHTS periods within each income group. This implies that regardless of how frequently one travels, people generally conduct similar types of daily activities year after year.

\subsubsection{Share of Daily Person-Trips by Mode and Income}

As displayed in Figure 4-5, very-low income residents of NYS were less likely to drive on a daily basis than their other income neighbors during all three NHTS years. Over half of the daily trips made by other income group in NYS were by driving during these years, as compared to a very-low income NYS resident who drove less than $30 \%$ of their daily trips. About $70 \%$ of 
person trips taken by a typical NYS other income person in 2009 were made in a privately owned vehicle (POV) (either as a driver or as a passenger). This share was about $47 \%$ for trips made by an average very-low income NYS individual during the same year.

On the other hand, a NYS very-low income resident was more than twice as likely to use public transit for daily travel as his/her counterpart other income neighbor in a given year-18\% versus $8 \%$ in 2009, respectively (Figure 4-5). Furthermore, the share of person trips made by walking was also significantly higher among the NYS very-low income population, as compared to their counterpart other income neighbors, about 29\% versus 20\% respectively during 2009. Mode shares for person trips within each given income category, as seen in Figure 4-5, generally did not show any significant changes over the last 14 years (from 1995 to 2009), except for walk trips and unreported modes. Note that 'mode not reported' is relatively much lower in 2001 and 2009, as compared to 1995, due to significant efforts and improvements of repeated survey for incomplete questionnaires.

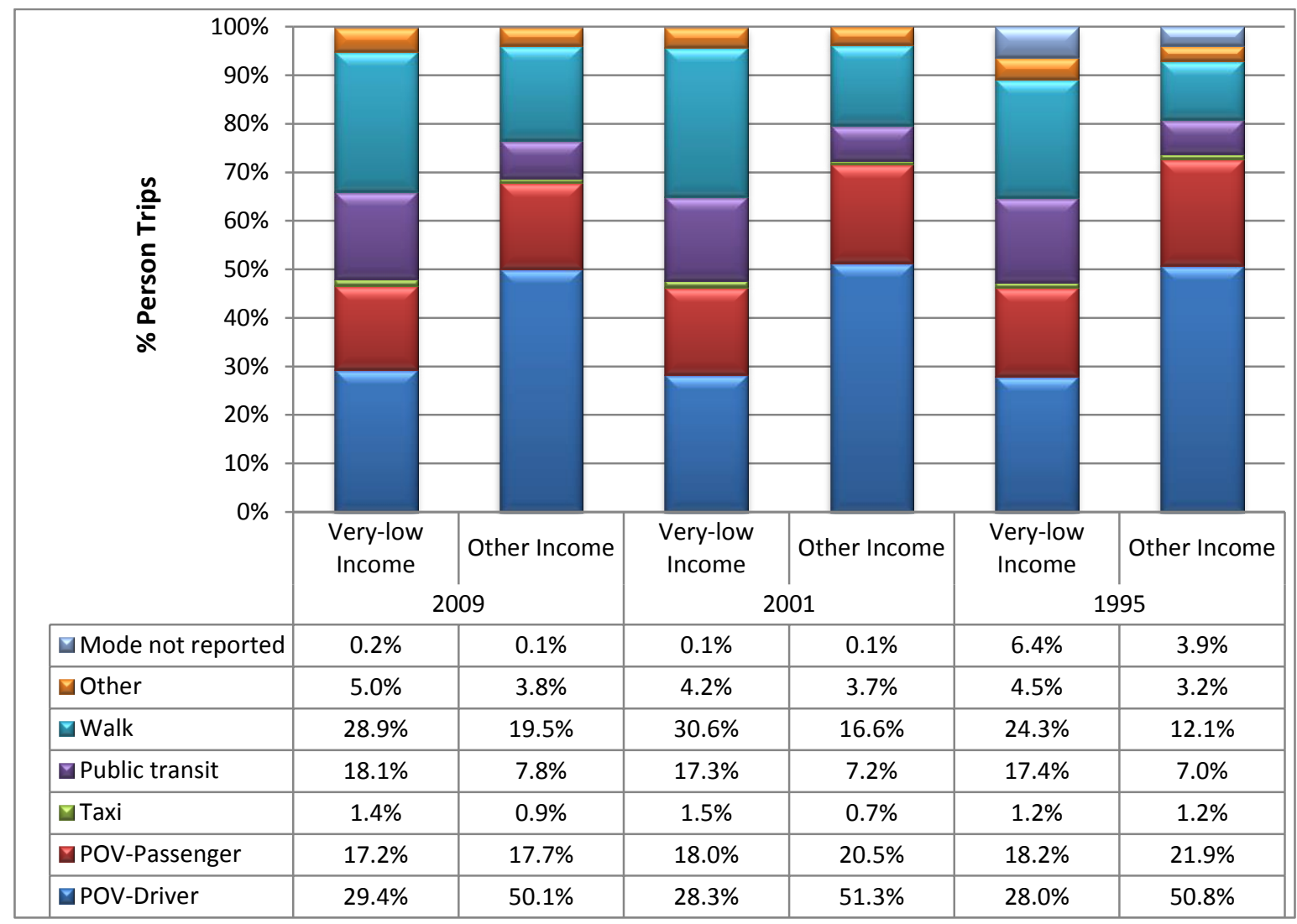

Figure 4-5. Distribution of NYS resident person trips by mode and income status (NHTS data)

\subsubsection{Regional Differences}

Transit and walking played a significant role in meeting travel needs for particularly Manhattan residents, regardless of their income status. As presented in Figure 4-6, for Manhattan residents, $90 \%$ of person trips made by very-low income residents and $71 \%$ of trips taken by their other income counterpart neighbors in 2009 were by public transit or walking. 
Not surprisingly, other Manhattan residents are more likely to travel by POV, as compared to the very-low income population from this same area. Outside of Manhattan, according to Figure 4-6 very-low income residents of NYC also have a significantly higher likelihood (69\%, total of $38 \%$ and $31 \%$ ) of utilizing public transit and walking in their daily travel activities, when compared to their neighbors in an other income category (51\% for public transit and walking).

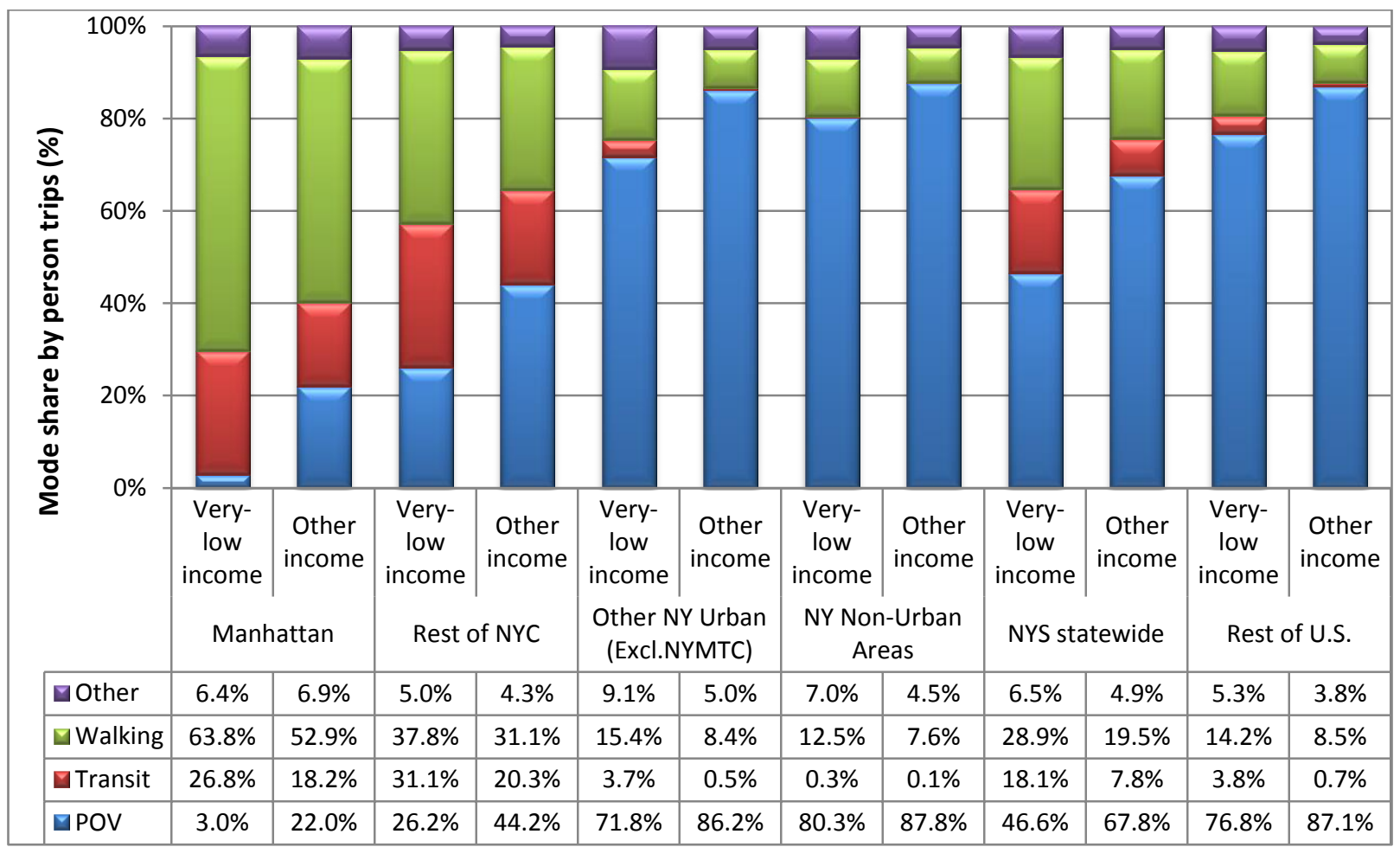

Figure 4-6. Comparison of mode shares by income status for selected areas in NYS and the Rest of U.S. (2009 NHTS)

On the other hand, Figure 4-6 shows there is a higher share of POV use (44\%) among other income population that lived in the Rest of NYC region, as compared to their very-low income neighbors $(26 \%)$. Transit clearly is not an alternative for the majority of NYS residents who lived outside of NYMTC or in rural areas of the state. For people outside of NYMTC, nearly $4 \%$ of person-trips for very-low income persons were made by public transit, while only $0.5 \%$ of trips made by their other income neighbors were on public transit. Figure 4-6 also shows that within each respective income level, the trip distributions by mode for residents of "other NY urban" and those of the Rest of U.S. area are relatively similar.

Figure 4-7 shows comparable mode share distributions using 2001 NHTS data. The modeshare patterns for all regions in each of the income groups are all consistent with those corresponding categories observed in Figure 4-6. The only exception is the very-low income category in Manhattan, where 2001 data showed a significantly lower share of walking and a significantly higher share of POV use than in 2009. 


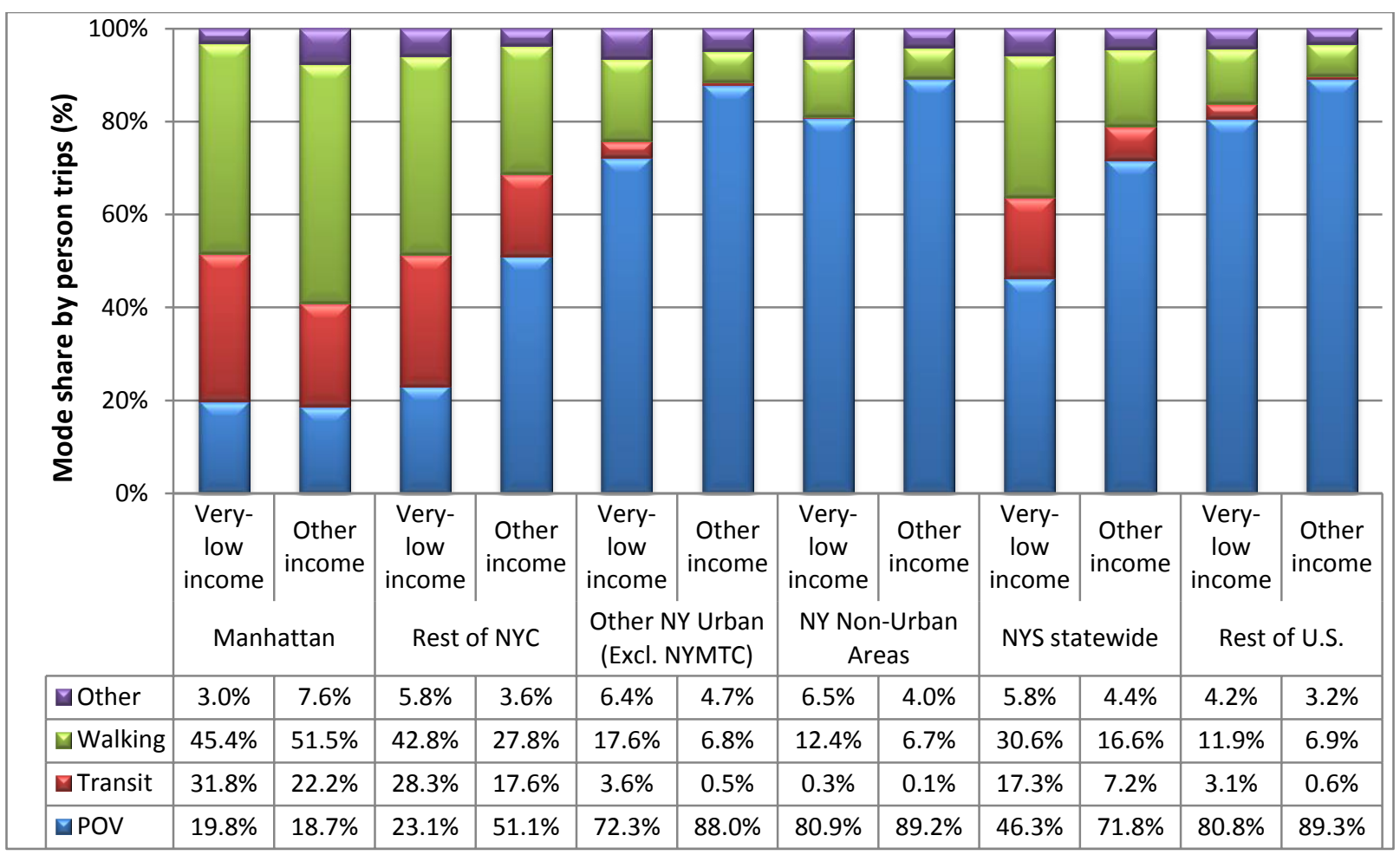

Figure 4-7. Comparison of mode shares by income status for selected areas in NYS and the Rest of U.S. (2001 NHTS)

\subsubsection{Impacts of Trip Purpose}

To illustrate whether mode use differs between income categories, and among various travel activities, Table 4-3 summarizes daily person-trips by mode, trip purpose, and income level, for NYS resident trips taken during the last three NHTS years (2009, 2001, and 1995). Clearly seen in Table 4-3, other income New Yorkers predominantly traveled by POVs (either as a driver or as a passenger) regardless of their trip purposes. Note that a POV was also the most chosen mode for very-low income NYS residents when making trips for work (earning a living) or for visiting family and conducting personal business. For trips made for school and religious activities, social and recreational, and other purposes, NYS's very-low income residents were most likely to use public transit or walk to reach their destinations. Nonetheless, Table 4-3 shows that NYS's very-low income persons clearly utilized public transit and walking significantly more frequently for all trip purposes than their other income neighbors. Note that cells estimated with a small number of samples are highlighted in yellow. 
Table 4-3. Daily NYS resident person-trips by mode, purpose, and income status - 2009, 2001, and 1995 NHTS

\begin{tabular}{|c|c|c|c|c|c|c|c|c|c|c|c|c|}
\hline \multicolumn{13}{|c|}{2009} \\
\hline & \multicolumn{2}{|c|}{ Earning a Living } & \multicolumn{2}{|c|}{$\begin{array}{c}\text { Family \& Personal } \\
\text { Business }\end{array}$} & \multicolumn{2}{|c|}{$\begin{array}{c}\text { Civic, Educational } \\
\text { \& Religious }\end{array}$} & \multicolumn{2}{|c|}{$\begin{array}{c}\text { Social \& } \\
\text { Recreational }\end{array}$} & \multicolumn{2}{|c|}{ Other } & \multicolumn{2}{|c|}{ All purposes } \\
\hline & Very-low & Other & $\begin{array}{c}\text { Very- } \\
\text { low }\end{array}$ & Other & $\begin{array}{c}\text { Very- } \\
\text { low }\end{array}$ & Other & $\begin{array}{c}\text { Very- } \\
\text { low }\end{array}$ & Other & $\begin{array}{c}\text { Very- } \\
\text { low }\end{array}$ & Other & $\begin{array}{c}\text { Very- } \\
\text { low }\end{array}$ & Other \\
\hline Average PT/person & 0.42 & 0.79 & 1.47 & 1.65 & 0.42 & $\mathbf{0 . 3 3}$ & 0.73 & 1.11 & 0.03 & 0.04 & 3.10 & 3.95 \\
\hline POV-Driver & $42.6 \%$ & $64.8 \%$ & $35.1 \%$ & $57.1 \%$ & $13.1 \%$ & $25.3 \%$ & $20.9 \%$ & $38.0 \%$ & $3.9 \%$ & $13.2 \%$ & $29.4 \%$ & $50.1 \%$ \\
\hline POV-Passenger & $12.7 \%$ & $5.6 \%$ & $17.4 \%$ & $16.4 \%$ & $14.9 \%$ & $27.7 \%$ & $20.4 \%$ & $25.1 \%$ & $20.1 \%$ & $23.0 \%$ & $17.2 \%$ & $17.7 \%$ \\
\hline Taxi & $1.3 \%$ & $0.9 \%$ & $1.9 \%$ & $0.5 \%$ & $0.5 \%$ & $1.0 \%$ & $0.9 \%$ & $1.2 \%$ & & $7.5 \%$ & $1.4 \%$ & $0.9 \%$ \\
\hline Public Transit & $30.7 \%$ & $16.6 \%$ & $13.0 \%$ & $4.9 \%$ & $21.9 \%$ & $10.1 \%$ & $18.2 \%$ & $4.9 \%$ & $18.1 \%$ & $21.2 \%$ & $18.1 \%$ & $7.8 \%$ \\
\hline Walk & $9.1 \%$ & $9.8 \%$ & $30.7 \%$ & $20.1 \%$ & $30.6 \%$ & $12.1 \%$ & $34.9 \%$ & $27.4 \%$ & $55.1 \%$ & $25.1 \%$ & $28.9 \%$ & $19.5 \%$ \\
\hline Other & $3.2 \%$ & $2.2 \%$ & $1.7 \%$ & $0.8 \%$ & $18.9 \%$ & $23.9 \%$ & $4.6 \%$ & $3.1 \%$ & $2.8 \%$ & $10.1 \%$ & $5.0 \%$ & $3.8 \%$ \\
\hline Unreported & $0.4 \%$ & $0.1 \%$ & $0.1 \%$ & $0.2 \%$ & $0.2 \%$ & $0.1 \%$ & & $0.1 \%$ & & & $0.2 \%$ & $0.1 \%$ \\
\hline All & $100 \%$ & $100 \%$ & $100 \%$ & $100 \%$ & $100 \%$ & $100 \%$ & $100 \%$ & $100 \%$ & $100 \%$ & $100 \%$ & $100 \%$ & $100 \%$ \\
\hline \multicolumn{13}{|c|}{2001} \\
\hline Average PT/person & 0.49 & 0.83 & 1.45 & 1.70 & 0.43 & 0.34 & 0.82 & 1.05 & 0.03 & 0.05 & 3.23 & 3.98 \\
\hline POV-Driver & $38.7 \%$ & $65.6 \%$ & $33.5 \%$ & $58.0 \%$ & $11.4 \%$ & $23.2 \%$ & $22.5 \%$ & $39.8 \%$ & $16.0 \%$ & $26.3 \%$ & $28.3 \%$ & $51.3 \%$ \\
\hline POV-Passenger & $12.0 \%$ & $5.9 \%$ & $18.2 \%$ & $19.4 \%$ & $14.5 \%$ & $29.6 \%$ & $23.1 \%$ & $30.4 \%$ & $14.2 \%$ & $20.7 \%$ & $18.0 \%$ & $20.5 \%$ \\
\hline Taxi & $1.1 \%$ & $1.2 \%$ & $1.7 \%$ & $0.4 \%$ & $1.0 \%$ & $0.6 \%$ & $1.4 \%$ & $0.8 \%$ & $1.2 \%$ & $0.9 \%$ & $1.5 \%$ & $0.7 \%$ \\
\hline Public Transit & $31.2 \%$ & $17.0 \%$ & $12.7 \%$ & $3.6 \%$ & $20.8 \%$ & $9.3 \%$ & $15.2 \%$ & $4.5 \%$ & $17.1 \%$ & $11.9 \%$ & $17.3 \%$ & $7.2 \%$ \\
\hline Walk & $14.2 \%$ & $8.3 \%$ & $32.2 \%$ & $17.7 \%$ & $37.0 \%$ & $15.9 \%$ & $33.9 \%$ & $21.2 \%$ & $46.3 \%$ & $27.0 \%$ & $30.6 \%$ & $16.6 \%$ \\
\hline Other & $2.7 \%$ & $2.0 \%$ & $1.7 \%$ & $1.0 \%$ & $15.0 \%$ & $21.3 \%$ & $3.7 \%$ & $3.3 \%$ & $4.7 \%$ & $12.8 \%$ & $4.2 \%$ & $3.7 \%$ \\
\hline Unreported & $0.1 \%$ & $0.1 \%$ & & $0.0 \%$ & $0.4 \%$ & $0.0 \%$ & $0.2 \%$ & $0.0 \%$ & $0.6 \%$ & $0.5 \%$ & $0.1 \%$ & $0.1 \%$ \\
\hline All & $100 \%$ & $100 \%$ & $100 \%$ & $100 \%$ & $100 \%$ & $100 \%$ & $100 \%$ & $100 \%$ & $100 \%$ & $100 \%$ & $100 \%$ & $100 \%$ \\
\hline \multicolumn{13}{|c|}{1995} \\
\hline Average PT/person & 0.44 & 0.89 & 1.62 & 1.90 & 0.43 & 0.35 & 0.94 & 1.01 & 0.00 & 0.01 & 3.43 & 4.16 \\
\hline POV-Driver & $39.9 \%$ & $65.9 \%$ & $34.3 \%$ & $56.2 \%$ & $10.6 \%$ & $20.7 \%$ & $19.3 \%$ & $37.9 \%$ & $23.5 \%$ & $30.6 \%$ & $28.0 \%$ & $50.8 \%$ \\
\hline POV-Passenger & $11.8 \%$ & $6.9 \%$ & $16.4 \%$ & $19.9 \%$ & $16.6 \%$ & $29.6 \%$ & $25.2 \%$ & $36.4 \%$ & $35.5 \%$ & $32.2 \%$ & $18.2 \%$ & $21.9 \%$ \\
\hline Taxi & $0.9 \%$ & $1.8 \%$ & $1.5 \%$ & $0.7 \%$ & $0.4 \%$ & $0.3 \%$ & $1.1 \%$ & $1.8 \%$ & 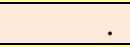 & . & $1.2 \%$ & $1.2 \%$ \\
\hline Public Transit & $29.7 \%$ & $15.6 \%$ & $13.7 \%$ & $3.6 \%$ & $18.1 \%$ & $8.9 \%$ & $17.8 \%$ & $4.9 \%$ & $10.1 \%$ & $2.0 \%$ & $17.4 \%$ & $7.0 \%$ \\
\hline Walk & $11.8 \%$ & $5.7 \%$ & $27.0 \%$ & $14.7 \%$ & $26.8 \%$ & $14.0 \%$ & $24.5 \%$ & $12.2 \%$ & & $26.0 \%$ & $24.3 \%$ & $12.1 \%$ \\
\hline Other & $2.3 \%$ & $1.7 \%$ & $1.0 \%$ & $0.8 \%$ & $19.1 \%$ & $23.3 \%$ & $5.1 \%$ & $2.0 \%$ & $27.0 \%$ & . & $4.5 \%$ & $3.2 \%$ \\
\hline Unreported & $3.5 \%$ & $2.4 \%$ & $6.3 \%$ & $4.2 \%$ & $8.3 \%$ & $3.3 \%$ & $6.9 \%$ & $4.8 \%$ & $4.1 \%$ & $9.1 \%$ & $6.4 \%$ & $3.9 \%$ \\
\hline All & $100 \%$ & $100 \%$ & $100 \%$ & $100 \%$ & $100 \%$ & $100 \%$ & $100 \%$ & $100 \%$ & $100 \%$ & $100 \%$ & $100 \%$ & $100 \%$ \\
\hline
\end{tabular}

Note: Yellow shaded cells are estimated based on small number of samples. 
Figure 4-8 emphasizes public transit shares for person-trips made by New Yorkers during the three NHTS years. As clearly shown in Figure 4-8, public transit was more frequently used among NYS's very-low income persons than trips made by their other income neighbors, regardless of trip purpose. Furthermore, Figure 4-9 shows that when a New Yorker in other income group used public transit in 2009 , there was a $43 \%$ chance that it was for commuting. However, public transit was more likely utilized by very-low income NYS residents for family and person business trips in 2009.

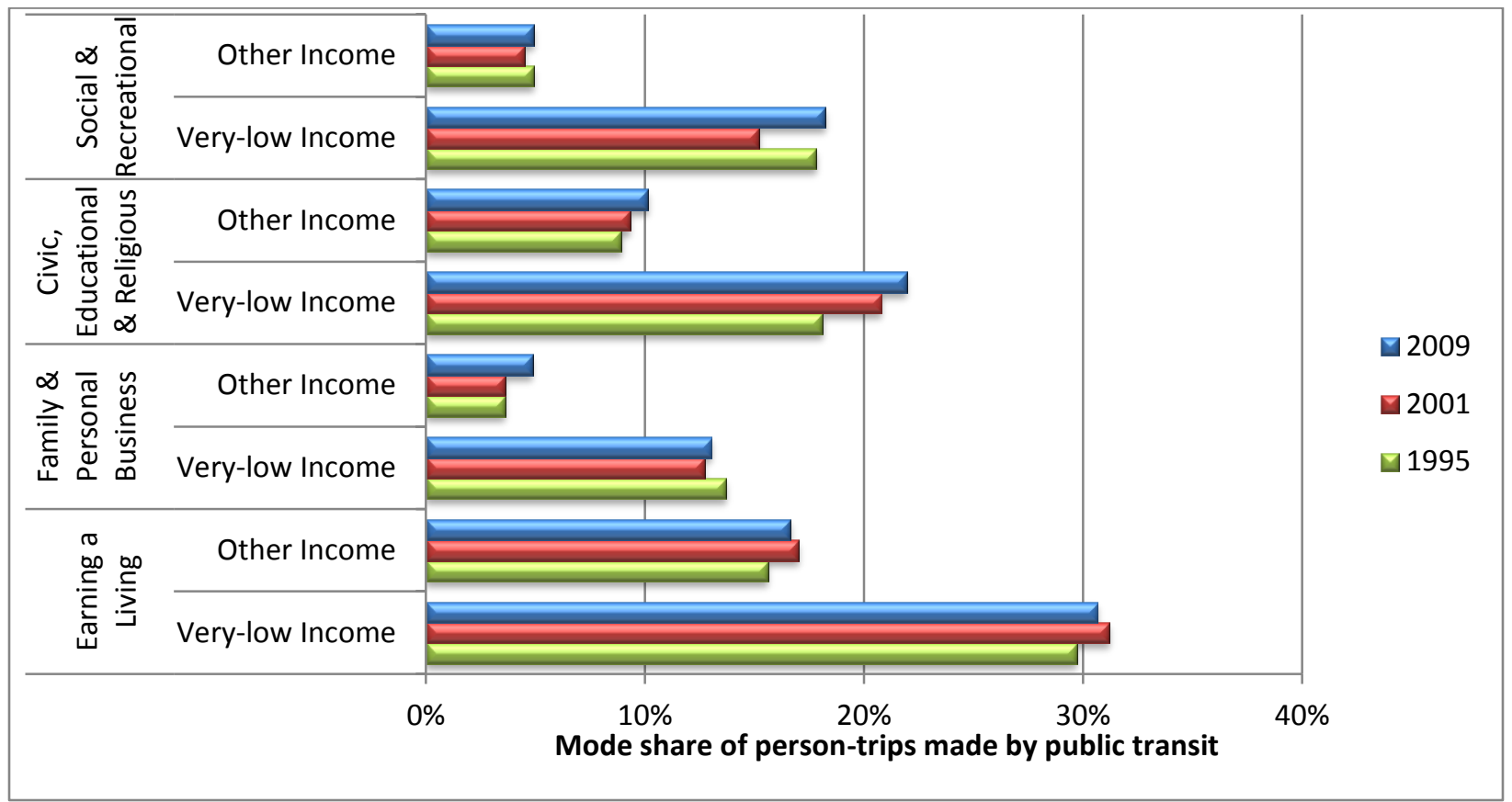

Figure 4-8. Percent of NYS's person-trips made on public transit, by purpose and income status (NHTS data)

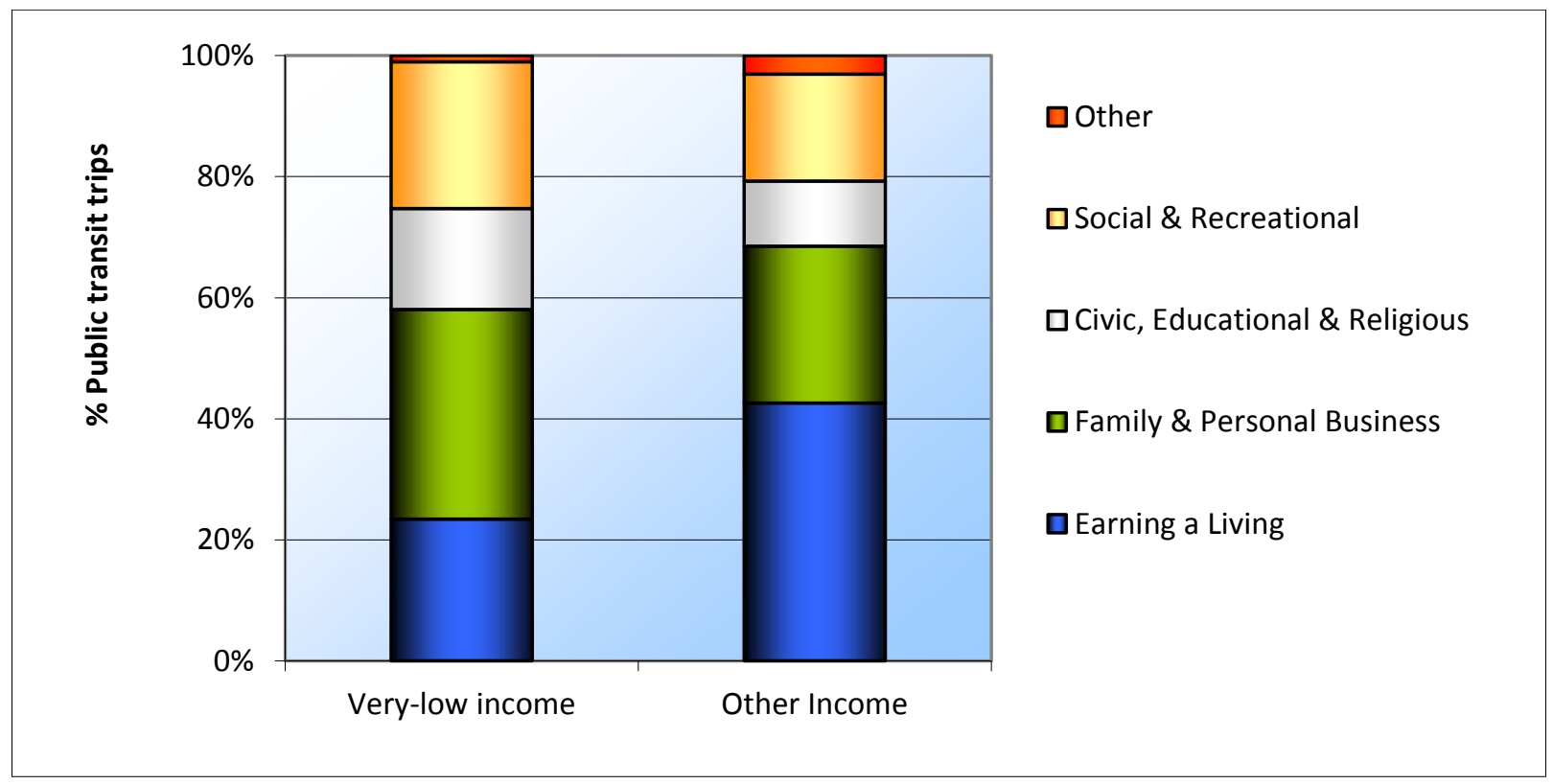

Figure 4-9. Distribution of public transit trips by purpose (2009 NHTS) 
Similarly, Figure 4-10 displays NYS resident person-trip shares for walk trips by trip purpose and income status. Except for work trips, NYS's very-low income residents had a higher likelihood of taking walk trips to conduct their daily activities for all non-work related purposes than those of their other income neighbors.

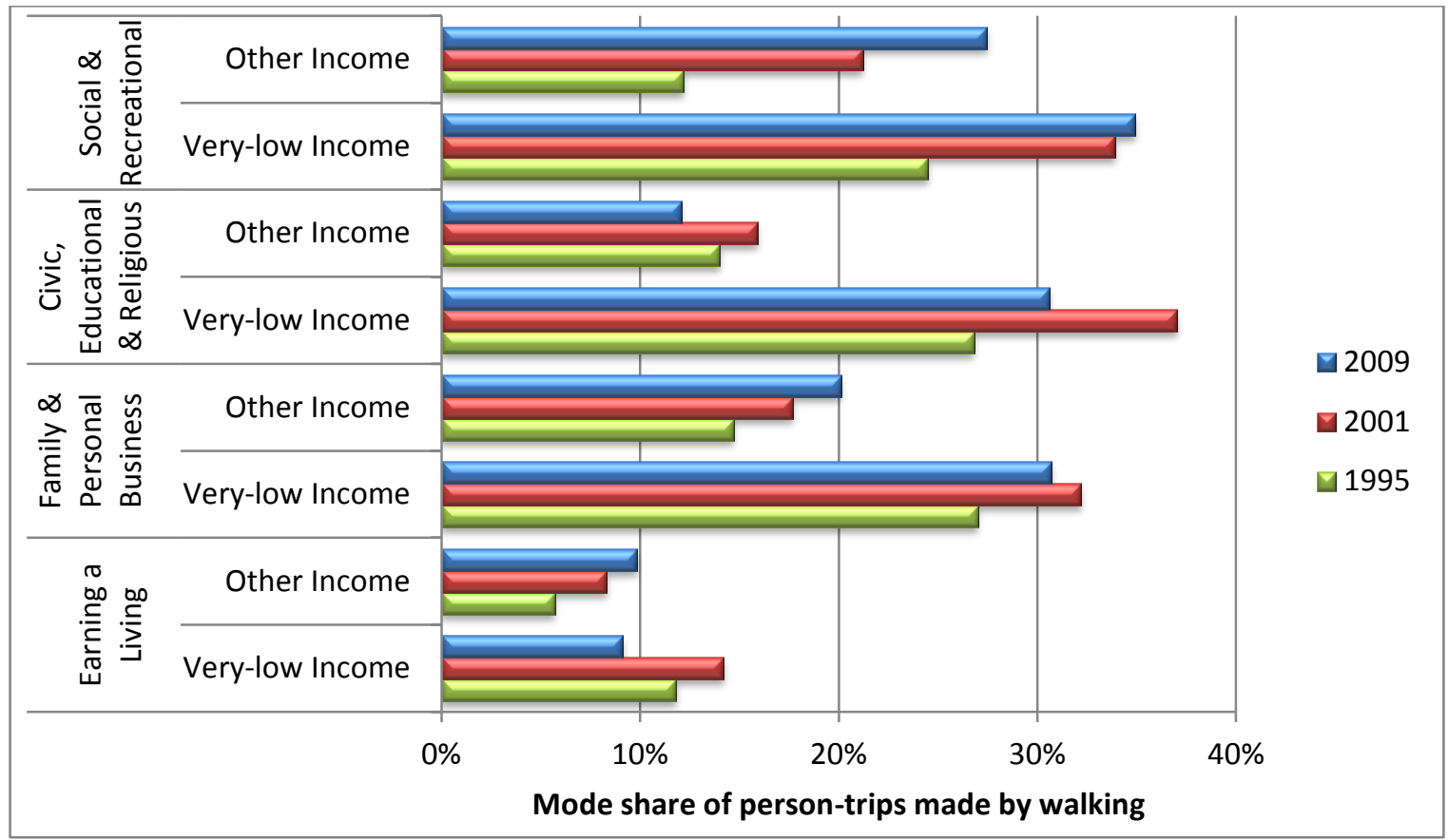

Figure 4-10. Percent of NYS's walking person-trips by trip purpose and income level (NHTS data)

\subsubsection{Influence of Urban Size (with Population Density)}

Considering geography, Table 4-4 presents mode shares on daily person-trips by region and income status using the latest three NHTS datasets. The proportion of walk trips made by NYC residents is remarkably high, a unique circumstance not seen in any other regions. During 2009, walk trips accounted for $41 \%$ of daily person-trips made by NYC's very-low income population, and about $37 \%$ among trips taken by other income persons in the same region. Outside of NYC in 2009, very-low income New Yorkers took about $9 \%$ to $19 \%$ of their daily person-trips on foot, depending on where they lived, compared to the shares of only $7 \%-11 \%$ among their other income neighbors (Table 4-4).

Table 4-4 also shows a significantly higher share of public transit use among very-low income NYC residents than that of their counterpart other income neighbors, $31 \%$ versus $20 \%$ respectively during 2009. Availability of public transit typically is limited in less dense urban areas (with population density <500) and rural areas of NYS, therefore transit mode shares in those areas are quite low regardless of the residents' income level. These regional public transit mode shares are further displayed in Figure 4-11 to illustrate the striking difference in public transit use between NYC and other regions. 
Table 4-4. Daily person-trips by mode, urban size (population density), and income status - 2009, 2001, and 1995 NHTS

\begin{tabular}{|c|c|c|c|c|c|c|c|c|c|c|c|c|c|c|c|c|}
\hline & \multicolumn{2}{|c|}{ New York City } & \multicolumn{2}{|c|}{ Rest of NYMTC } & \multicolumn{2}{|c|}{$\begin{array}{c}\text { Other urban, dens } \\
<500\end{array}$} & \multicolumn{2}{|c|}{$\begin{array}{c}\text { Other urban, dens } \\
500-1999 \\
\end{array}$} & \multicolumn{2}{|c|}{$\begin{array}{c}\text { Other urban, dens } \\
2000+\end{array}$} & \multicolumn{2}{|c|}{$\begin{array}{l}\text { NYS Non-urban } \\
\text { areas }\end{array}$} & \multicolumn{2}{|c|}{ NYS Statewide } & \multicolumn{2}{|c|}{ Rest of U.S. } \\
\hline & $\begin{array}{l}\text { Very- } \\
\text { low }\end{array}$ & Other & $\begin{array}{l}\text { Very- } \\
\text { low }\end{array}$ & Other & $\begin{array}{l}\text { Very- } \\
\text { low }\end{array}$ & Other & $\begin{array}{l}\text { Very- } \\
\text { low }\end{array}$ & Other & $\begin{array}{l}\text { Very- } \\
\text { low }\end{array}$ & Other & $\begin{array}{l}\text { Very- } \\
\text { low }\end{array}$ & Other & $\begin{array}{l}\text { Very- } \\
\text { low }\end{array}$ & Other & $\begin{array}{l}\text { Very- } \\
\text { low }\end{array}$ & Other \\
\hline \multicolumn{17}{|c|}{2009} \\
\hline Average & & & & & & & & & & & & & & & & \\
\hline PT/person & 2.95 & 3.91 & 3.65 & 4.07 & $\frac{3.11}{58.607}$ & $\frac{3.76}{65006}$ & $\frac{3.13}{50.27}$ & 4.01 & 3.08 & 4.16 & $\frac{\mathbf{3 . 0 4}}{53.7 \%}$ & 3.69 & 3.10 & $\frac{3.95}{50.107}$ & 3.25 & $\frac{\mathbf{4 . 0 4}}{639 \%}$ \\
\hline $\begin{array}{l}\text { POV-Driver } \\
\text { POV nassen }\end{array}$ & $\frac{11.0 \%}{12.4 \%}$ & $\frac{25.4 \%}{125 \%}$ & $\frac{46.6 \%}{23.7 \%}$ & $\frac{62.4 \%}{201 \%}$ & $\frac{58.6 \%}{26.2 \%}$ & $\frac{65.9 \%}{21.8 \%}$ & $\frac{50.2 \%}{22.4 \%}$ & $\frac{65.5 \%}{20.4 \%}$ & $\frac{49.1 \%}{16.8 \%}$ & $\frac{64.9 \%}{20.2 \%}$ & $\frac{53.7 \%}{26.6 \%}$ & $\frac{65.6 \%}{22.3 \%}$ & $\frac{29.4 \%}{17.2 \%}$ & $\frac{50.1 \%}{17.7 \%}$ & $\frac{49.3 \%}{27.5 \%}$ & $\frac{63.9 \%}{23.3 \%}$ \\
\hline Taxi & $1.8 \%$ & $2.4 \%$ & $1.4 \%$ & $0.1 \%$ & $0.0 \%$ & $0.0 \%$ & $0.5 \%$ & $0.1 \%$ & $1.5 \%$ & $0.1 \%$ & $0.2 \%$ & $0.1 \%$ & $1.4 \%$ & $0.9 \%$ & $0.3 \%$ & $0.1 \%$ \\
\hline Public Transit & $30.6 \%$ & $19.7 \%$ & $6.0 \%$ & $2.1 \%$ & $0.4 \%$ & $0.3 \%$ & $3.8 \%$ & $0.3 \%$ & $5.0 \%$ & $0.7 \%$ & $0.3 \%$ & $0.1 \%$ & $18.1 \%$ & $7.8 \%$ & $3.8 \%$ & $0.7 \%$ \\
\hline Walk & $40.9 \%$ & $37.3 \%$ & $16.5 \%$ & $10.9 \%$ & $8.7 \%$ & $6.9 \%$ & $13.9 \%$ & $8.2 \%$ & $18.9 \%$ & $9.9 \%$ & $12.5 \%$ & $7.6 \%$ & $28.9 \%$ & $19.5 \%$ & $14.2 \%$ & $8.5 \%$ \\
\hline Other & $3.4 \%$ & $2.6 \%$ & $5.2 \%$ & $4.3 \%$ & $5.9 \%$ & $4.9 \%$ & $9.4 \%$ & $5.3 \%$ & $8.7 \%$ & $3.8 \%$ & $6.7 \%$ & $4.4 \%$ & $5.0 \%$ & $3.8 \%$ & $4.7 \%$ & $3.6 \%$ \\
\hline No R & $0.0 \%$ & $0.1 \%$ & $0.6 \%$ & $0.1 \%$ & $0.2 \%$ & $0.2 \%$ & & $0.2 \%$ & $0.0 \%$ & $0.3 \%$ & $0.1 \%$ & $0.1 \%$ & $0.2 \%$ & $0.1 \%$ & $0.2 \%$ & $0.2 \%$ \\
\hline All & $100.0 \%$ & $100.0 \%$ & $100.0 \%$ & $100.0 \%$ & $100.0 \%$ & $100.0 \%$ & $100.0 \%$ & $100.0 \%$ & $100.0 \%$ & $100.0 \%$ & $100.0 \%$ & $100.0 \%$ & $100.0 \%$ & $100.0 \%$ & $100.0 \%$ & $100.0 \%$ \\
\hline \multicolumn{17}{|c|}{2001} \\
\hline $\begin{array}{l}\text { Average } \\
\text { PT/person }\end{array}$ & 3.03 & 3.79 & 3.48 & 3.94 & 3.29 & 3.92 & 3.78 & 4.30 & 3.54 & 4.28 & 3.61 & 4.14 & 3.23 & 3.98 & 3.49 & 4.35 \\
\hline POV-Driver & $12.0 \%$ & $29.1 \%$ & $50.7 \%$ & $61.7 \%$ & $56.0 \%$ & $64.4 \%$ & $55.1 \%$ & $65.3 \%$ & $42.4 \%$ & $63.4 \%$ & $50.1 \%$ & $62.9 \%$ & $28.3 \%$ & $51.3 \%$ & $50.5 \%$ & $64.0 \%$ \\
\hline POV passenger & $10.7 \%$ & $14.2 \%$ & $27.1 \%$ & $22.2 \%$ & $28.0 \%$ & $24.6 \%$ & $29.9 \%$ & $23.1 \%$ & $23.6 \%$ & $23.7 \%$ & $30.8 \%$ & $26.4 \%$ & $18.0 \%$ & $20.5 \%$ & $30.3 \%$ & $25.3 \%$ \\
\hline Taxi & $1.7 \%$ & $1.7 \%$ & $0.4 \%$ & $0.3 \%$ & & $0.0 \%$ & $0.1 \%$ & $0.1 \%$ & $2.8 \%$ & $0.2 \%$ & $0.8 \%$ & $0.1 \%$ & $1.5 \%$ & $0.7 \%$ & $0.1 \%$ & $0.1 \%$ \\
\hline Public Transit & $28.8 \%$ & $18.7 \%$ & $3.6 \%$ & $2.4 \%$ & $0.4 \%$ & $0.2 \%$ & $0.4 \%$ & $0.4 \%$ & $5.3 \%$ & $0.7 \%$ & $0.3 \%$ & $0.1 \%$ & $17.3 \%$ & $7.2 \%$ & $3.1 \%$ & $0.6 \%$ \\
\hline Walk & $43.2 \%$ & $33.5 \%$ & $12.8 \%$ & $9.4 \%$ & $8.6 \%$ & $5.8 \%$ & $9.9 \%$ & $6.3 \%$ & $22.0 \%$ & $7.9 \%$ & $12.4 \%$ & $6.7 \%$ & $30.6 \%$ & $16.6 \%$ & $11.9 \%$ & $6.9 \%$ \\
\hline Other & $3.5 \%$ & $2.8 \%$ & $5.3 \%$ & $3.8 \%$ & $6.9 \%$ & $5.0 \%$ & $4.5 \%$ & $4.8 \%$ & $4.0 \%$ & $3.9 \%$ & $5.7 \%$ & $3.9 \%$ & $4.2 \%$ & $3.7 \%$ & $3.9 \%$ & $3.1 \%$ \\
\hline No Response & $0.2 \%$ & $0.1 \%$ & $0.1 \%$ & $0.1 \%$ & $0.1 \%$ & $0.0 \%$ & $0.1 \%$ & $0.1 \%$ & & $0.1 \%$ & & $0.0 \%$ & $0.1 \%$ & $0.1 \%$ & $0.1 \%$ & $0.1 \%$ \\
\hline All & $100.0 \%$ & $100.0 \%$ & $100.0 \%$ & $100.0 \%$ & $100.0 \%$ & $100.0 \%$ & $100.0 \%$ & $100.0 \%$ & $100.0 \%$ & $100.0 \%$ & $100.0 \%$ & $100.0 \%$ & $100.0 \%$ & $100.0 \%$ & $100.0 \%$ & $100.0 \%$ \\
\hline \multicolumn{17}{|c|}{1995} \\
\hline & & & & & & & & & & & & & & & & \\
\hline$\frac{\text { PT/ } /}{\text { POI }}$ & $\frac{\mathbf{3 . 3 3}}{10.0 \%}$ & $\frac{\mathbf{3 . 9 3}}{27.4 \%}$ & $\frac{\mathbf{3 . 5 9}}{48.2 \%}$ & $\frac{\mathbf{4 . 2 3}}{60.7 \%}$ & $\frac{\mathbf{3 . 7 2}}{56.2 \%}$ & $\frac{\mathbf{4 . 1 4}}{65.7 \%}$ & $\frac{\mathbf{4 . 0 1}}{54.0 \%}$ & $\frac{\mathbf{4 . 3 3}}{60.7 \%}$ & $\frac{\mathbf{3 . 5 0}}{48.4 \%}$ & $\frac{\mathbf{4 . 4 6}}{63.0 \%}$ & $\frac{\mathbf{3 . 4 0}}{55.3 \%}$ & $\frac{4.24}{61.6 \%}$ & $\frac{\mathbf{3 . 4 3}}{28.0 \%}$ & $\frac{\mathbf{4 . 1 6}}{50.8 \%}$ & $\frac{\mathbf{3 . 7 5}}{49.5 \%}$ & $\frac{4.57}{63.8 \%}$ \\
\hline POV passenger & $11.8 \%$ & $15.5 \%$ & $26.9 \%$ & $24.3 \%$ & $30.5 \%$ & $25.2 \%$ & $27.2 \%$ & $26.2 \%$ & $22.3 \%$ & $23.7 \%$ & $28.8 \%$ & $26.3 \%$ & $18.2 \%$ & $21.9 \%$ & $28.3 \%$ & $25.9 \%$ \\
\hline Taxi & $1.6 \%$ & $3.2 \%$ & $0.9 \%$ & $0.3 \%$ & $0.1 \%$ & $0.0 \%$ & $0.4 \%$ & $0.1 \%$ & $0.9 \%$ & $0.2 \%$ & $0.4 \%$ & & $1.2 \%$ & $1.2 \%$ & $0.3 \%$ & $0.1 \%$ \\
\hline Public Transit & $28.6 \%$ & $18.7 \%$ & $2.7 \%$ & $2.5 \%$ & $0.2 \%$ & $0.4 \%$ & $2.8 \%$ & $0.5 \%$ & $6.7 \%$ & $1.6 \%$ & $0.6 \%$ & $0.5 \%$ & $17.4 \%$ & $7.0 \%$ & $3.6 \%$ & $0.8 \%$ \\
\hline Walk & $37.0 \%$ & $28.6 \%$ & $8.3 \%$ & $5.5 \%$ & $3.4 \%$ & $1.9 \%$ & $6.8 \%$ & $3.8 \%$ & $11.9 \%$ & $4.7 \%$ & $5.0 \%$ & $3.3 \%$ & $24.3 \%$ & $12.1 \%$ & $9.4 \%$ & $3.9 \%$ \\
\hline Other & $3.6 \%$ & $1.7 \%$ & $8.4 \%$ & $3.4 \%$ & $4.9 \%$ & $4.3 \%$ & $3.8 \%$ & $4.9 \%$ & $3.7 \%$ & $2.6 \%$ & $5.1 \%$ & $4.8 \%$ & $4.5 \%$ & $3.2 \%$ & $4.2 \%$ & $2.8 \%$ \\
\hline No Response & $7.4 \%$ & $4.8 \%$ & $4.5 \%$ & $3.3 \%$ & $4.8 \%$ & $2.5 \%$ & $5.2 \%$ & $3.9 \%$ & $6.1 \%$ & $4.2 \%$ & $4.9 \%$ & $3.4 \%$ & $6.4 \%$ & $3.9 \%$ & $4.8 \%$ & $2.8 \%$ \\
\hline All & $100.0 \%$ & $100.0 \%$ & $100.0 \%$ & $100.0 \%$ & $100.0 \%$ & $100.0 \%$ & $100.0 \%$ & $100.0 \%$ & $100.0 \%$ & $100.0 \%$ & $100.0 \%$ & $100.0 \%$ & $100.0 \%$ & $100.0 \%$ & $100.0 \%$ & $100.0 \%$ \\
\hline
\end{tabular}

Note: Yellow shaded cells are estimates based on small samples. 


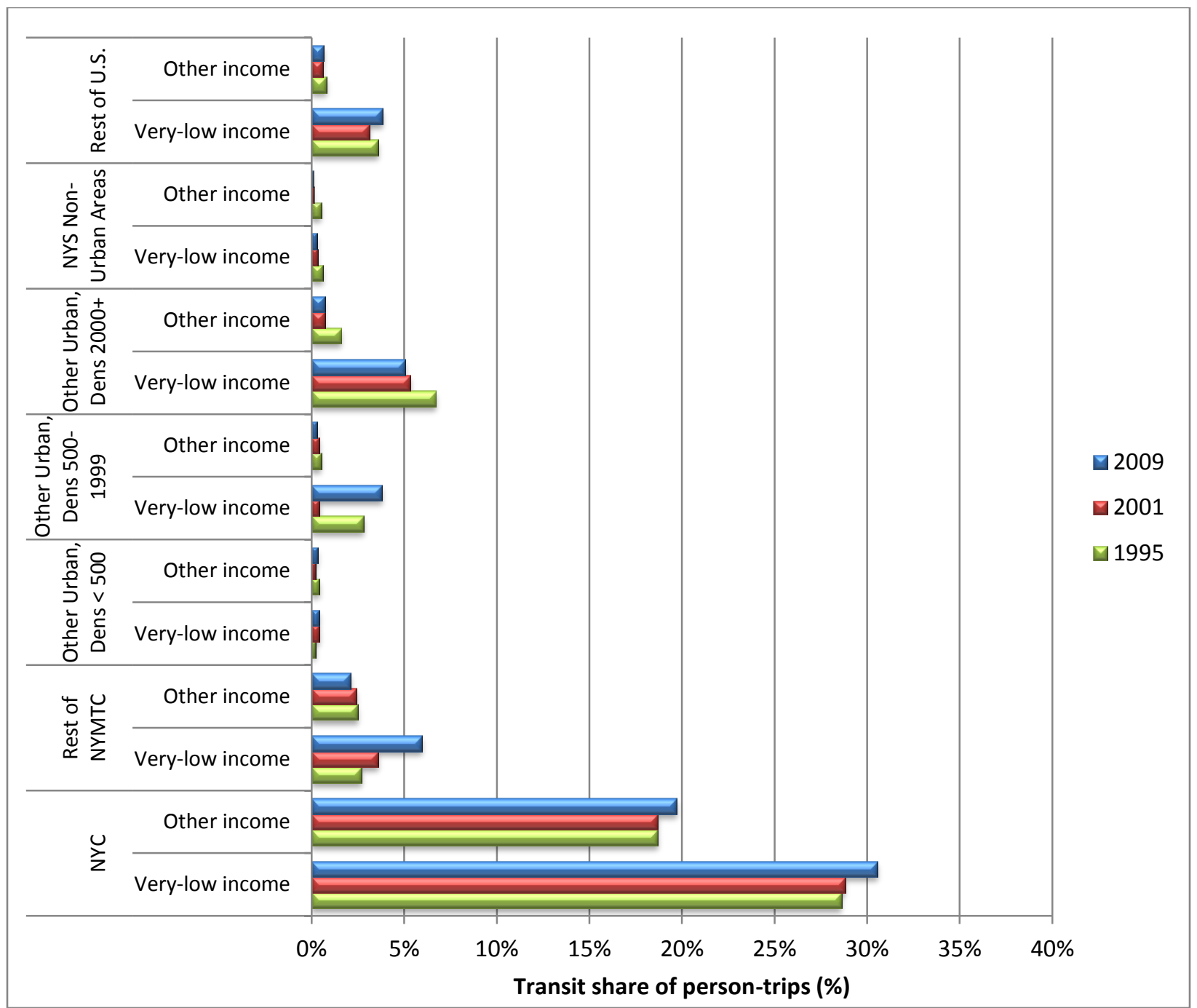

Figure 4-11. Transit person-trip mode shares by urban size (in population density) and income level (NHTS data)

\subsection{MOBILITY STATISTICS RELATED TO TRIP LENGTH}

\subsubsection{Average Person-Miles Traveled}

Based on NHTS data, NYS residents from a very-low-income household traveled significantly fewer miles (i.e., shorter trip distances) as measured by person-miles traveled (PMT), as compared to trips made by other income households. Specifically, in 2009, very-low income New Yorkers traveled an average of 14 miles per day versus 32 miles per day by their counterpart other income New Yorkers (Figure 4-12). Although Figure 4-12 seems to show a slightly declining trend in average PMT for NYS's very-low income population, those differences were not statistically significant. 


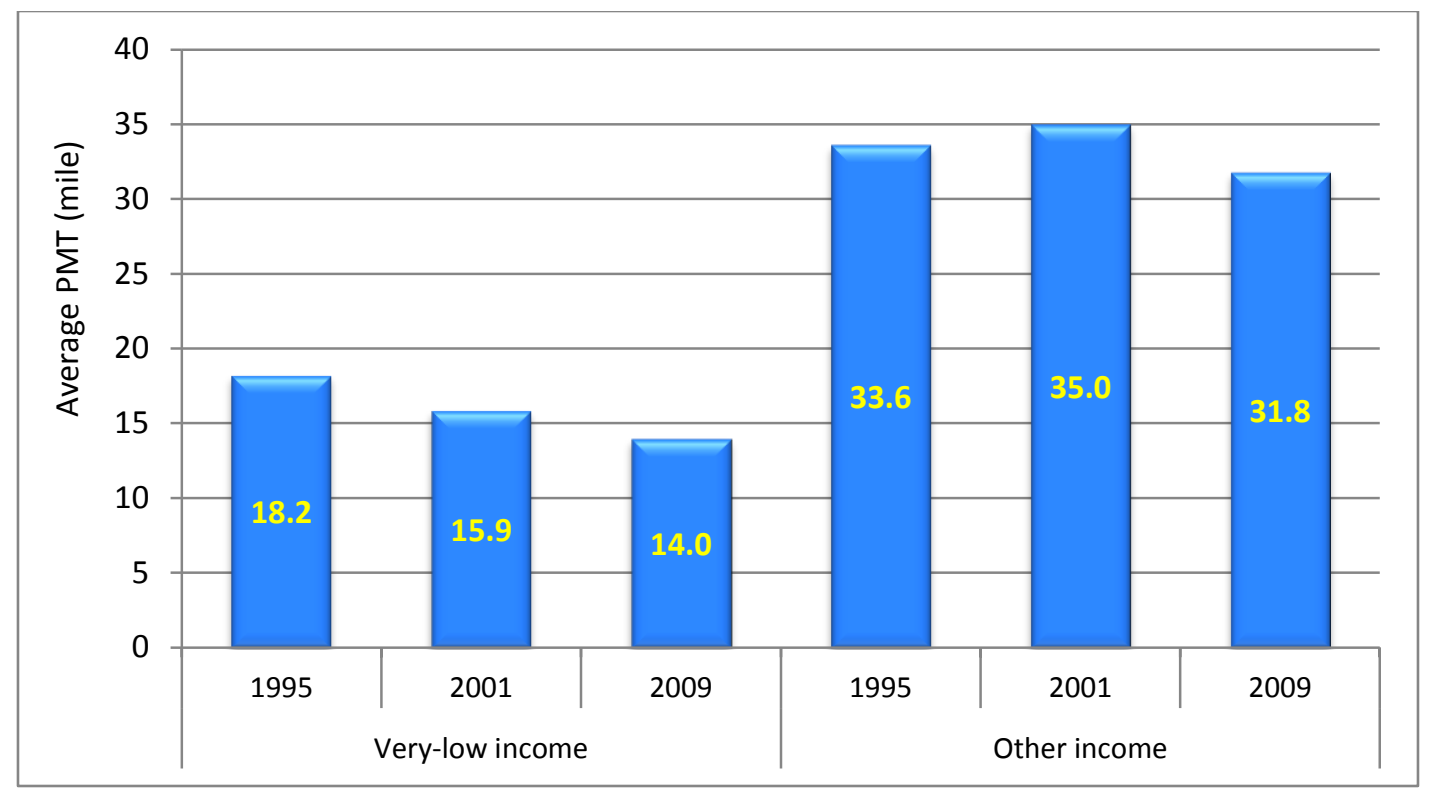

Figure 4-12. Average person-miles traveled by income status for NYS (NHTS data)

\subsubsection{Distribution of PMT by Trip Purpose}

Figure 4-13 displays the distributions of average daily PMT for NYS, by trip purpose and income group. Specifically, Figure 4-13 shows that a significant share ( $40 \%)$ of PMT made by very-low income residents in 2009 was to conduct family \& personal business. During the same year (2009), however, PMT made by a typical other income person was more evenly distributed among work, family/personal, and social/recreational activities. Distribution wise, there is not any visible difference over time in PMT shares by trip purpose among the other group. For the very-low income group, there is a slight increase in PMT share (about 5\%) for work trips, and a decrease in PMT share (near 10\%) for social/recreational trips, in 2009

Note that the data label shown on each segment of the bars in Figure 4-13 represents the share of PMT in miles for the given type of activity (i.e., trip purpose) in the given income group. Using the 2009 very-low income group as an example, the values on the blue segment indicates that out of the 14 miles of PMT (average per person PMT seen in Figure 4-12), a total of 3.4 miles were for work trips (where $3.4 / 14=24 \%$ ). Similarly, the number on the red segment indicates that 5.6 miles (within the 14 miles of daily average PMT) were for "family \& personal business" trips (where 5.6/14=40\%).

Based on the estimates of purpose-specific PMTs (Figure 4-13), a typical very-low income New Yorker traveled significantly fewer miles than one from other income households for travels associated with work, family/personal business, or social/recreational activities. The significant income-gap on average PMTs is true in each of the three NHTS years. Changes over time in average PMTs for a given trip purpose and within the same income group are not statistically significant, however. 


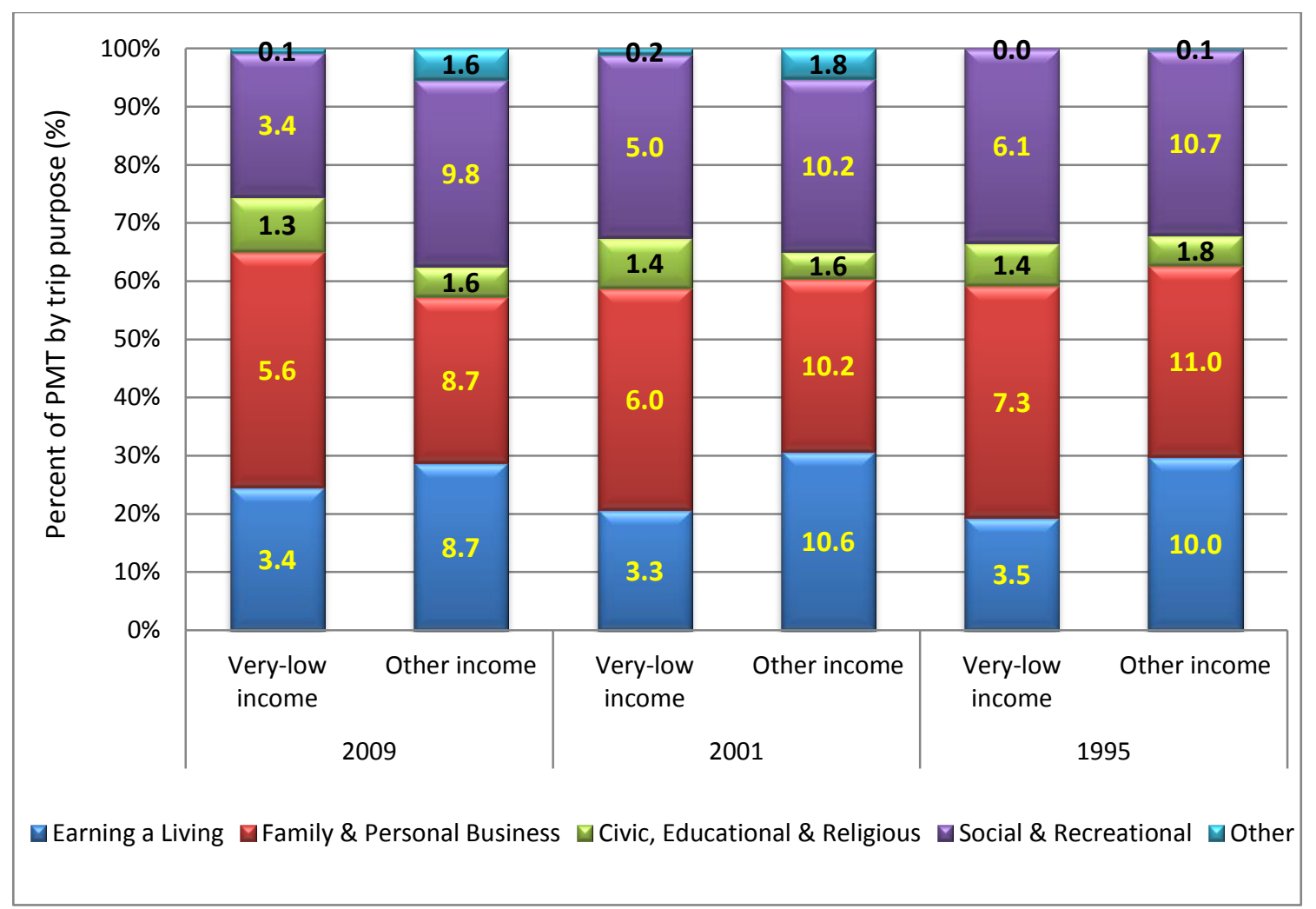

Figure 4-13. Distribution of PMT by trip purpose and income status for NYS (NHTS data)

\subsubsection{Impacts of Income on Average Person-Trip Length (Distance)}

On average, persons from a very-low-income household traveled significantly shorter distances for daily activities (measured in person-trips), as compared to trips taken by their neighbors in other income group. As seen in Figure 4-14, a typical person-trip made by very-low income residents of Manhattan during 2009 was 1.6 miles per trip, versus 5.6 miles per trip for their counterpart other income neighbors. In urban areas outside of NYMTC, a typical very-low income person traveled an average of 6.5 miles per trip, as compared to an average other income counterpart who traveled about 53\% farther per trip or an average of 10 miles per person-trip.

Furthermore, Figure 4-14 shows that, statewide, very-low income NYS residents traveled about 5.1 miles per trip on average, while their other income neighbors took $62 \%$ longer trips, just over 8.3 miles per trip on average. Outside of NYS, the average length of person-trips taken by the very-low income group was 7.7 miles per trip in 2009 (Figure 4-14), versus 10.4 miles per trip (or 35\% longer in distance) for trips made by their counterpart other income neighbors. A similar analysis using NHTS 2001 data was also performed and the results are presented in Figure 4-15. Person-trip length was higher in 2001 (compared to the 2009 level) for trips made by other income residents of NYC regions, and for very-low income residents from Manhattan. 


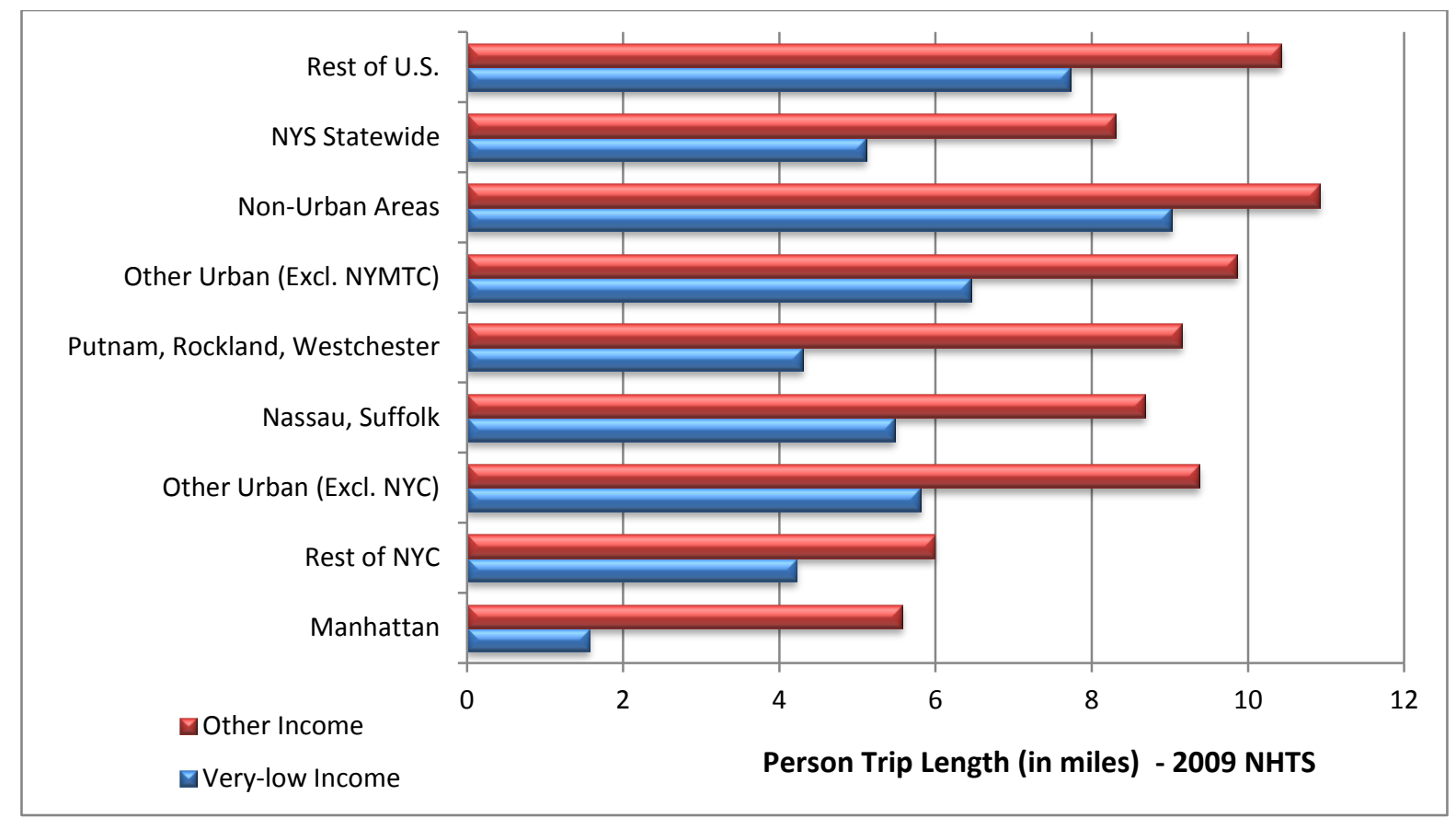

Figure 4-14. Average daily person-trip length (in miles) by region and income status (2009 NHTS)

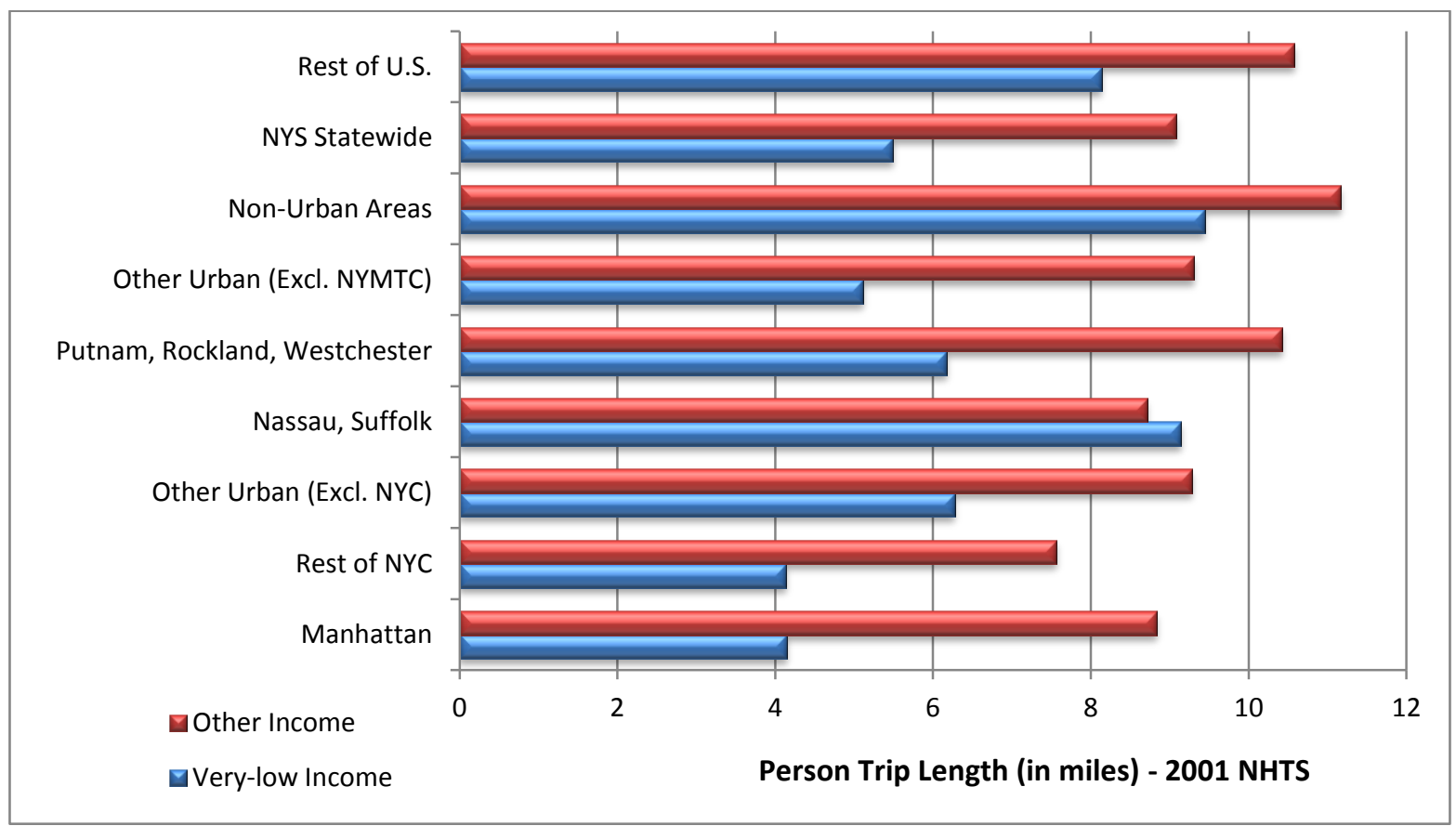

Figure 4-15. Average daily person-trip length (in miles) by region and income status (2001 NHTS) 


\subsection{VEHICLE TRAVEL TRIP FREQUENCIES}

\subsubsection{Average Daily Vehicle-Trip Rate}

Regarding vehicle trips, NYS drivers from very-low income households took a significantly fewer number of vehicle trips than their counterpart other income drivers in each of the three NHTS years. Specifically, as shown in Figure 4-16, a typical very-low income driver from NYS made only 1.7 vehicle trips per day in 2009, versus an average of 2.6 vehicle trips for drivers from other income households in NYS during the same year. Clearly, Figure 4-16 shows a visible decline in the average number of vehicle trips over time, for both income categories. These declines in both income groups, especially from 2001 to 2009, are statistically significant.

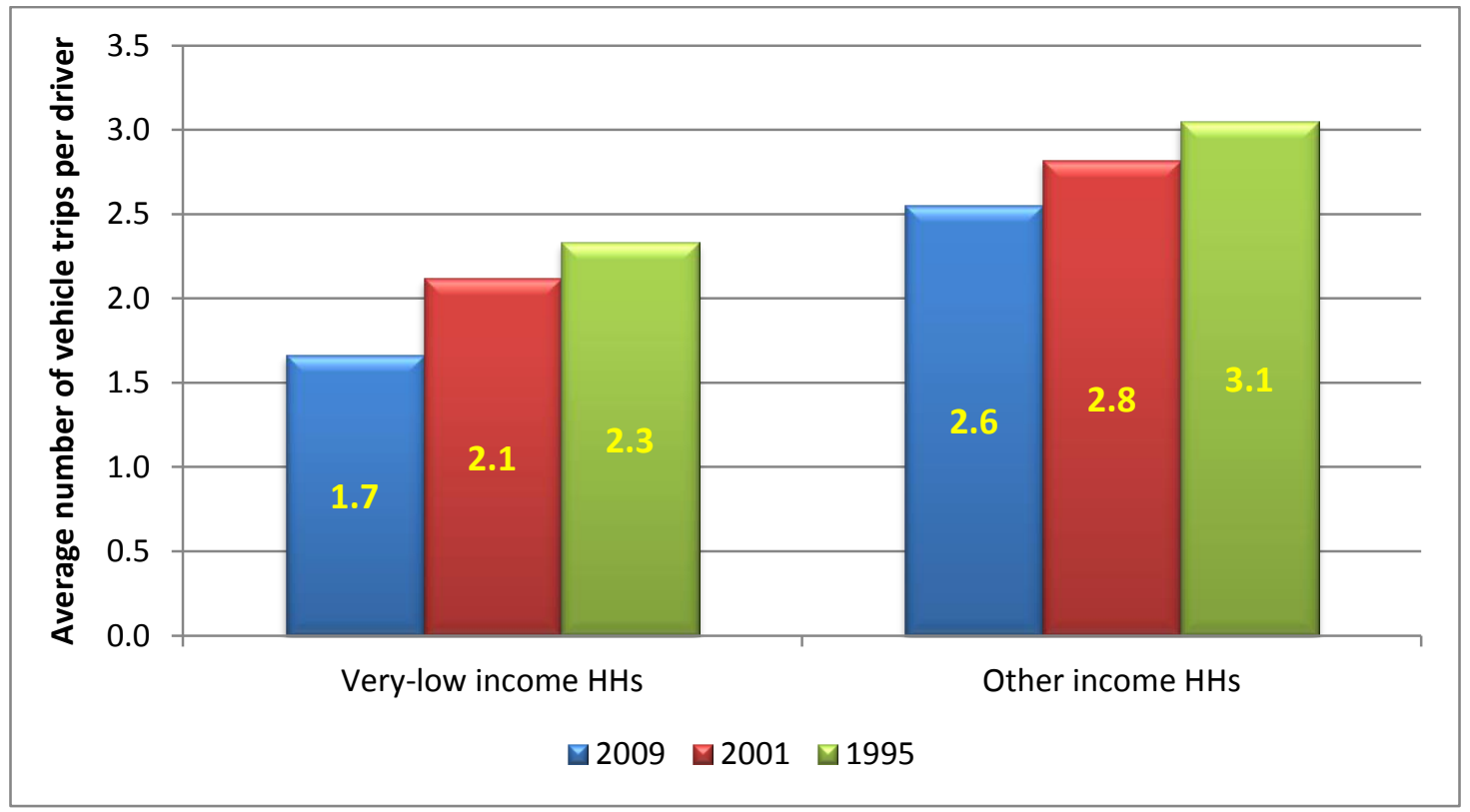

Figure 4-16. Average vehicle-trip rates by income status for NYS households (NHTS data)

\subsubsection{Regional Differences in Vehicle-Trip Rates}

In addition to examining all NYS drivers' vehicle-trip frequencies as a whole, potential regional differences in drivers' travel patterns were also investigated. On average, NYS drivers from very-low-income households made fewer vehicle trips, as compared to trips made by their counterpart drivers from other income households, regardless of where they lived. As Figure 4-17 shows, NYC drivers clearly had the least number of vehicle-trips per driver (about 1 trip) than drivers from any other regions (around 3 trips), including areas within and outside of NYS. In all areas examined, drivers from very-low-income households, on average, made fewer vehicle-trips than their counterpart other income neighbors during the same year. A reduction in the average number of vehicle-trips over time in either income group is also visible for nearly all regions presented in Figure 4-17. 


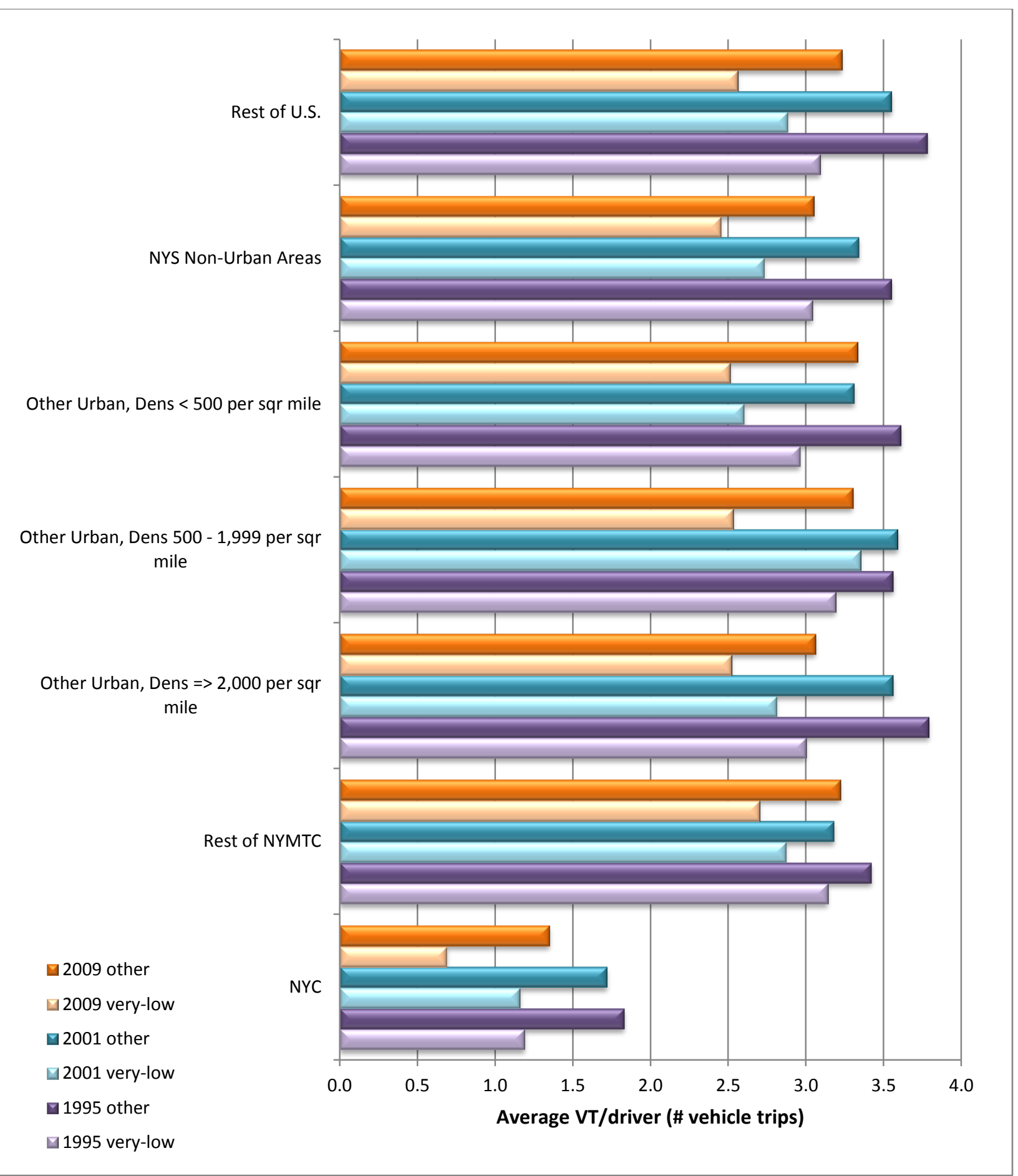

Figure 4-17. Average number of vehicle-trips/driver by region/population-density and income status (NHTS data) 


\subsubsection{Share of Vehicle-Trips per Driver by Purpose}

The statistics for average vehicle-trips per driver, as presented in Figure 4-16, were further analyzed to examine whether income status has any influence on the different travel activities. With respect to the distributions of vehicle-trips per driver in 2009, Figure 4-18 reveals that a very-low income driver has a smaller share of work-related vehicle trips (20\%), as compared to $26 \%$ for work-related vehicle trips among their counterpart neighbors with other income. On the other hand, a very-low income driver has a higher share of "family and personal business" vehicle-trips (57\%), as compared to a NYS driver with other income (48\%) during the same year.

Furthermore, as the yellow "data labels" in Figure 4-18 show, a very-low income NYS driver took less than 0.4 vehicle trips daily for "earning a living,", while a driver from other income households in NYS made about twice as many vehicle trips per day for the same trip purpose. This pattern was repeated across all three NHTS years for drivers in both income groups. In addition, a very-low income NYS driver made roughly one vehicle trip daily for "family and personal business" activities during 2009. During the same period, the counterpart other income NYS driver took about $33 \%$ more vehicle trips (1.2 vehicle-trips) per day for those same activities.

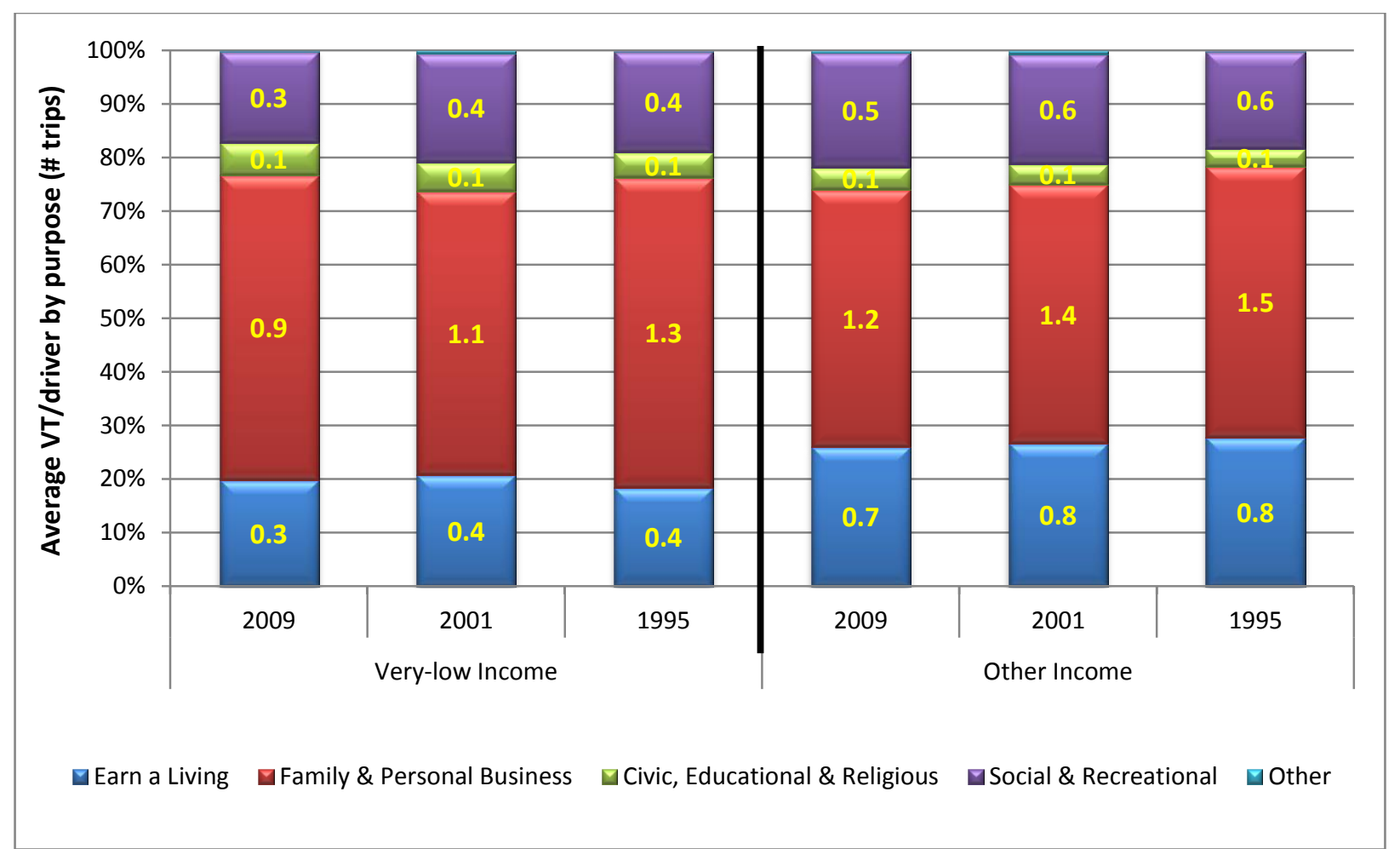

Figure 4-18. Distribution and number of average vehicle-trips for NYS drivers by trip purpose and income status (NHTS data)

Figure 4-18 shows a declining trend in the average number of vehicle-trips made for "family and personal business" purposes on a per driver basis. This pattern is not as visible in other 
types of activities, however. Because the predominant shares of daily vehicle-trips taken by NYS drivers were made for "family and personal business" purposes (as seen in Figure 4-18), the declining trend can be attributed to the overall pattern seen in Figure 4-16.

As summarized in Table 4-5, a typical very-low income driver is more likely to take vehicle trips for "family/personal business" activities, when compared with other income households. This is consistent across all regions (including outside NYS) and all population densities studied in NYS. On the other hand, Table 4-5 shows that drivers with very-low income traveled fewer vehicle-trips for "earn a living" purposes as compared to their other income counterpart drivers from the same region. For example, Table 4-5 indicates that about $14 \%$ of daily vehicle-trips taken by a very-low income NYC driver were to earn a living versus $19 \%$ for a driver with other income in 2009. Furthermore, in NYS's rural area (i.e., non-urban area), about $29 \%$ of vehicle trips made by a higher income driver were for work purposes, compared to $20 \%$ for a typical driver who was from very-low income households during 2009. 
Table 4-5. Average number of vehicle trips (VT) per driver by purpose, population density, and income status (2009, 2001, and 1995 NHTS data)

\begin{tabular}{|c|c|c|c|c|c|c|c|c|c|c|c|c|c|c|}
\hline \multirow{2}{*}{ Trip Purposes } & \multicolumn{2}{|c|}{ NYC } & \multicolumn{2}{|c|}{ Rest of NYMTC } & \multicolumn{2}{|c|}{$\begin{array}{c}\text { Other Urban, dens } \\
\text { < 500/sqr-mile }\end{array}$} & \multicolumn{2}{|c|}{$\begin{array}{l}\text { Other Urban, dens } \\
500-1,999 / \text { sqr-mile }\end{array}$} & \multicolumn{2}{|c|}{$\begin{array}{c}\text { Other Urban, dens } \\
>=2,000 / \text { sqr-mile }\end{array}$} & \multicolumn{2}{|c|}{$\begin{array}{l}\text { NYS non-Urban } \\
\text { areas }\end{array}$} & \multicolumn{2}{|c|}{ Rest of U.S. } \\
\hline & $\begin{array}{c}\text { Very- } \\
\text { low }\end{array}$ & Other & $\begin{array}{l}\text { Very- } \\
\text { low } \\
\end{array}$ & Other & $\begin{array}{c}\text { Very- } \\
\text { low }\end{array}$ & Other & $\begin{array}{l}\text { Very- } \\
\text { low }\end{array}$ & Other & $\begin{array}{c}\text { Very- } \\
\text { low }\end{array}$ & Other & $\begin{array}{c}\text { Very- } \\
\text { low }\end{array}$ & Other & $\begin{array}{c}\text { Very- } \\
\text { low }\end{array}$ & Other \\
\hline & \multicolumn{14}{|c|}{2009 NHTS } \\
\hline Total VT/Driver & 0.69 & 1.35 & 2.70 & 3.22 & 2.52 & 3.06 & 2.53 & 3.30 & 2.51 & $\mathbf{3 . 3 3}$ & 2.45 & 3.05 & 2.56 & 3.23 \\
\hline Earn a Living & $14.3 \%$ & $19.1 \%$ & $21.6 \%$ & $25.7 \%$ & $21.4 \%$ & $29.0 \%$ & $21.4 \%$ & $28.7 \%$ & $20.6 \%$ & $26.6 \%$ & $20.1 \%$ & $29.4 \%$ & $20.9 \%$ & $27.4 \%$ \\
\hline $\begin{array}{l}\text { Family/Personal } \\
\text { Business }\end{array}$ & $67.5 \%$ & $52.7 \%$ & $54.5 \%$ & $48.5 \%$ & $54.8 \%$ & $45.2 \%$ & $52.7 \%$ & $44.6 \%$ & $52.5 \%$ & $45.7 \%$ & $54.6 \%$ & $45.1 \%$ & $53.2 \%$ & $45.2 \%$ \\
\hline $\begin{array}{l}\text { Civic, Educational } \\
\text { \& Religious }\end{array}$ & $3.8 \%$ & $3.4 \%$ & $7.8 \%$ & $4.8 \%$ & $3.9 \%$ & $3.6 \%$ & $4.7 \%$ & $4.3 \%$ & $7.4 \%$ & $4.6 \%$ & $5.6 \%$ & $3.8 \%$ & $5.6 \%$ & $4.8 \%$ \\
\hline Social/Recreational & $13.3 \%$ & $23.1 \%$ & $15.7 \%$ & $20.1 \%$ & $18.6 \%$ & $21.1 \%$ & $20.6 \%$ & $21.3 \%$ & $18.7 \%$ & $22.5 \%$ & $19.3 \%$ & $20.5 \%$ & $19.0 \%$ & $21.5 \%$ \\
\hline Other & $0.0 \%$ & $0.2 \%$ & $0.4 \%$ & $0.6 \%$ & $0.2 \%$ & $0.3 \%$ & $0.0 \%$ & $0.2 \%$ & $0.0 \%$ & $0.1 \%$ & $0.0 \%$ & $0.1 \%$ & $0.3 \%$ & $0.3 \%$ \\
\hline Unrepc & $1.1 \%$ & $1.6 \%$ & $0.1 \%$ & $4 \%$ & $1.2 \%$ & $0.9 \%$ & $0.7 \%$ & $1.0 \%$ & $0.8 \%$ & $0.5 \%$ & $0.3 \%$ & $1.1 \%$ & $1.1 \%$ & $0.8 \%$ \\
\hline \multirow[t]{2}{*}{ All } & $100 \%$ & $100 \%$ & $100 \%$ & $00 \%$ & $100 \%$ & $100 \%$ & $100 \%$ & $100 \%$ & $100 \%$ & $100 \%$ & $100 \%$ & $100 \%$ & $100 \%$ & $100 \%$ \\
\hline & \multicolumn{14}{|c|}{2001 NHTS } \\
\hline Total V & 1.16 & 72 & 2.87 & 18 & 2.6 & 3.31 & 3.35 & 3.59 & 2.81 & 3.56 & 2.73 & $\mathbf{3 . 3 4}$ & 2.88 & 3.55 \\
\hline Earn a Living & $25.60 \%$ & $25.80 \%$ & $21.30 \%$ & $.20 \%$ & $16.30 \%$ & $29.30 \%$ & $12.70 \%$ & $26.70 \%$ & $16.20 \%$ & $5.70 \%$ & $3.10 \%$ & $27.60 \%$ & $21.00 \%$ & $27.40 \%$ \\
\hline $\begin{array}{l}\text { Fami } \\
\text { Busir }\end{array}$ & $0 \%$ & $49.70 \%$ & $48.30 \%$ & $47.90 \%$ & $55.10 \%$ & $47.00 \%$ & $53.30 \%$ & $47.70 \%$ & $52.40 \%$ & $48.90 \%$ & $55.40 \%$ & $47.80 \%$ & $52.40 \%$ & $47.10 \%$ \\
\hline $\begin{array}{l}\text { ucational } \\
\text { pus }\end{array}$ & $3.80 \%$ & $3.70 \%$ & $6.70 \%$ & $3.90 \%$ & $3.90 \%$ & $3.20 \%$ & $7.60 \%$ & $4.70 \%$ & $6.60 \%$ & $4.20 \%$ & $4.00 \%$ & $3.30 \%$ & $6.30 \%$ & $4.70 \%$ \\
\hline Social/Re & $.40 \%$ & $19.40 \%$ & $22.80 \%$ & $21.20 \%$ & $22.90 \%$ & $20.00 \%$ & $25.90 \%$ & $20.30 \%$ & $24.10 \%$ & $20.70 \%$ & $17.10 \%$ & $20.80 \%$ & $20.00 \%$ & $20.20 \%$ \\
\hline Other & $0.00 \%$ & $1.30 \%$ & $0.90 \%$ & $0.60 \%$ & $1.20 \%$ & $0.40 \%$ & $0.30 \%$ & $0.50 \%$ & $0.70 \%$ & $0.50 \%$ & $0.30 \%$ & $0.30 \%$ & $0.30 \%$ & $0.50 \%$ \\
\hline Unreport & $0.10 \%$ & $0.10 \%$ & & $0.20 \%$ & $0.60 \%$ & $0.10 \%$ & $0.30 \%$ & $0.10 \%$ & $0.00 \%$ & $0.10 \%$ & $0.10 \%$ & $0.30 \%$ & $0.10 \%$ & $0.10 \%$ \\
\hline \multirow[t]{2}{*}{ All } & $100 \%$ & $100 \%$ & $100 \%$ & $100 \%$ & $100 \%$ & $100 \%$ & $100 \%$ & $100 \%$ & $100 \%$ & $100 \%$ & $100 \%$ & $100 \%$ & $100 \%$ & $100 \%$ \\
\hline & \multicolumn{14}{|c|}{1995 NHTS } \\
\hline Total VT/Driver & 1.19 & $1.0 \mathrm{~J}$ & 3.14 & & 2.96 & 3.61 & 3.19 & 3.56 & 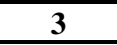 & 3.79 & 3.04 & 3.55 & 3.09 & 3.78 \\
\hline Earn a Living & $16.3 \%$ & $27.5 \%$ & $21.4 \%$ & $26.4 \%$ & $19.3 \%$ & $30.5 \%$ & $13.3 \%$ & $27.0 \%$ & $19.0 \%$ & $27.4 \%$ & $17.5 \%$ & $29.7 \%$ & $21.0 \%$ & $28.8 \%$ \\
\hline $\begin{array}{l}\text { Family/Personal } \\
\text { Business }\end{array}$ & 60.3 & $51.2 \%$ & $57.7 \%$ & 5 & $55.9 \%$ & $48.5 \%$ & $61.8 \%$ & 6 & $\%$ & $\%$ & $.2 \%$ & $3 \%$ & $9 \%$ & $9.2 \%$ \\
\hline $\begin{array}{l}\text { Civic, Educational } \\
\& \text { Religious }\end{array}$ & $6.2 \%$ & $4.0 \%$ & $6.1 \%$ & $3.4 \%$ & $3.4 \%$ & $3.2 \%$ & $4.0 \%$ & $3.8 \%$ & $5.1 \%$ & $2.7 \%$ & $2.2 \%$ & $3.3 \%$ & $5.6 \%$ & $3.9 \%$ \\
\hline Social/Recreational & $17.2 \%$ & $17.2 \%$ & $14.5 \%$ & $18.3 \%$ & $21.4 \%$ & $17.8 \%$ & $20.9 \%$ & $18.5 \%$ & $24.2 \%$ & $18.5 \%$ & $19.6 \%$ & $18.6 \%$ & $18.5 \%$ & $18.0 \%$ \\
\hline Other & & $0.0 \%$ & & $0.1 \%$ & & $0.1 \%$ & $0.0 \%$ & $0.1 \%$ & & $0.1 \%$ & $0.3 \%$ & $0.1 \%$ & $0.0 \%$ & $0.1 \%$ \\
\hline Unreported & & & $0.3 \%$ & $0.0 \%$ & & & & & & $0.1 \%$ & $0.2 \%$ & & $0.0 \%$ & $0.0 \%$ \\
\hline All & $100 \%$ & $100 \%$ & $0 \%$ & $0 \%$ & $00 \%$ & $00 \%$ & $100 \%$ & $100 \%$ & $100 \%$ & $100 \%$ & $100 \%$ & $100 \%$ & $100 \%$ & $100 \%$ \\
\hline
\end{tabular}

Note: Yellow shaded cell estimates were based on small samples 


\subsection{INFLUENCE OF INCOME ON VEHICLE-TRIP LENGTH}

\subsubsection{Vehicle-Miles Traveled per Driver}

Figure 4-19 presents the average daily vehicle-miles traveled (VMT) by income level of drivers who lived in NYS. According to NHTS 2009 data, a very-low income driver from NYS traveled about 11.2 vehicle-miles daily in 2009, as compared to twice as many (22.6) vehiclemiles per day from a NYS driver in other income households. This echoes with how a NYS very-low income driver traveled significantly less frequent in a vehicle as well as made considerably shorter vehicle trips, when compared to vehicle trips made by other income drivers from NYS. This situation also holds true for previous NHTS years, although the gap due to income levels (on average daily VMT) was smaller, less than $40 \%$ in both 2001 and 1995 . Like vehicle-trips (see Figure 4-16), a decreasing trend in VMT over time is visible in Figure 4-19. Within each income category, this downward trend in average daily VMT per driver, between 2001 and 2009, was found to be statistically significant.

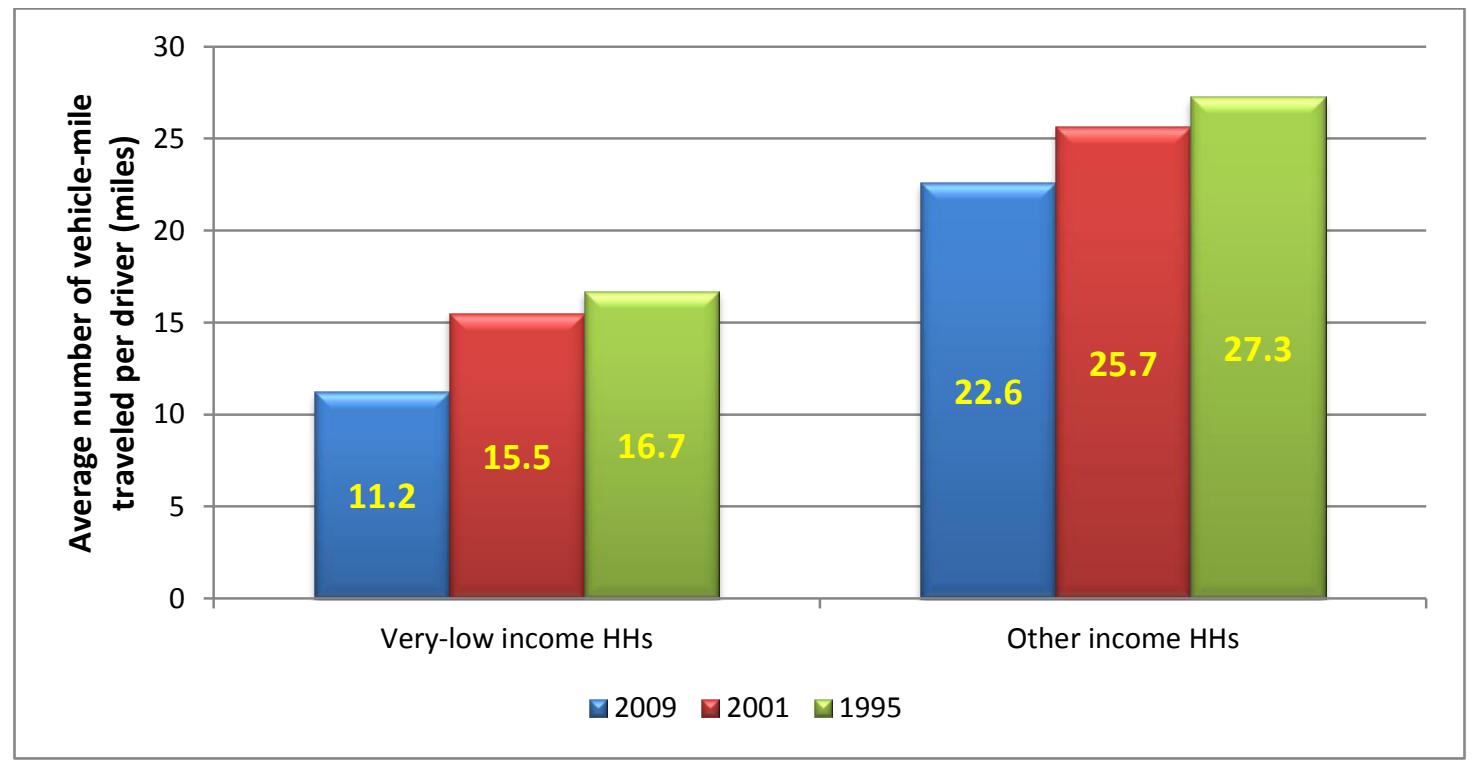

Figure 4-19. Average daily VMT (miles) by income status for drivers in NYS (NHTS data)

Likewise, income influence on the shares of trip purpose as measured in daily VMT per driver was also examined using NHTS data. Using the 2009 average daily VMT of a very-low income driver, Figure 4-20 shows that 2.8 miles of the total 11.2 VMT (see Figure 4-19), i.e., $25 \%$ in shares, were attributed to trips made for "earn a living" purposes. On the other hand, 8 miles out of the daily average of 22.6 miles in VMT (i.e., $35 \%$ share) traveled by other income drivers were made for the same purpose during 2009. Moreover, a typical higher income NYS driver is not only more likely to use a vehicle for work trips than a low-income driver, but also higher-income drivers also traveled more vehicle miles than their counterpart drivers from verylow income households ( 8 miles versus under 3 miles, respectively). 
As shown in Figure 4-20, on a VMT per driver basis, nearly half of the daily VMT made by a very-low income NYS driver in 2009 was made to conduct family/personal business. Only about one-third of daily VMT by other income drivers was taken for the same reason during that year.

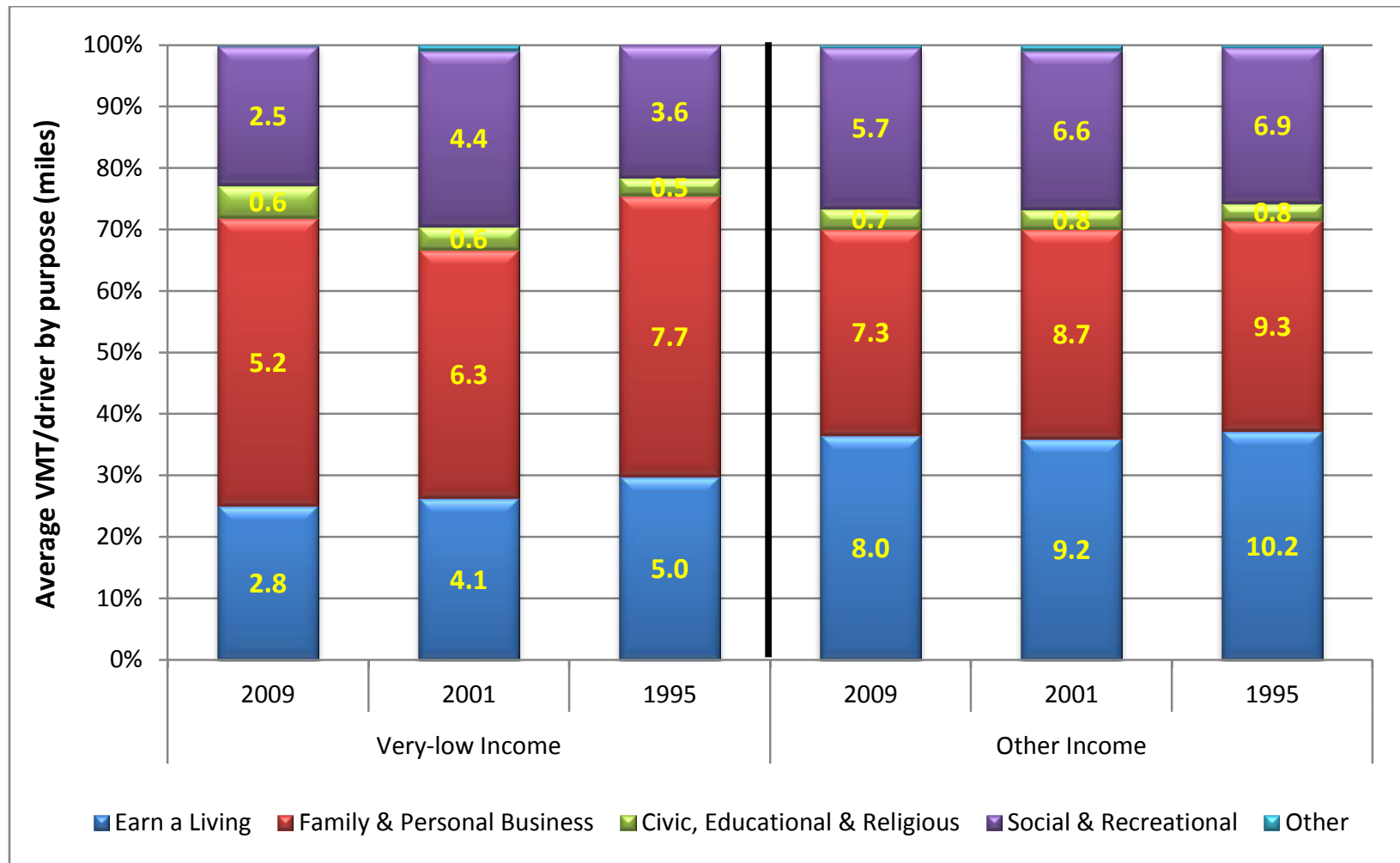

Figure 4-20. Distribution of daily vehicle-miles traveled (VMT) by trip purpose and income status (NHTS data)

\subsubsection{Average Vehicle-Trip Distance}

The NYS drivers from a very-low-income household not only traveled fewer vehicle-miles, as compared to their counterpart neighbors from other income households (Figure 4-19); they also made shorter vehicle trips than drivers from other income households. As displayed in Figure 4-21, drivers from a very-low income household in NYS traveled about 7 miles per vehicle-trip on a typical day in 2009, while drivers with higher income traveled an average of 2 miles further (29\% more miles) for each vehicle trip taken during the same year. Unlike VMT, there were no significant differences in the average vehicle-trip length over the three NHTS years among drivers from each given income category.

Regardless of the size of population density, drivers from very-low income households consistently made shorter vehicle-trips, on average, than drivers with higher incomes (Figure 4-21). According to the 2009 NHTS data, population density seems to have an impact on the length of vehicle-trips for urban regions that are outside NYMTC-i.e., the higher the density, the longer the average trip length (Figure 4-22). Interestingly, a reversed pattern from those 
observed in previous NHTS data (2001 and 1995) was seen. There are no significant differences in the average vehicle-trip length for drivers from NYC and those of the rest of NYMTC, regardless of drivers' income status.

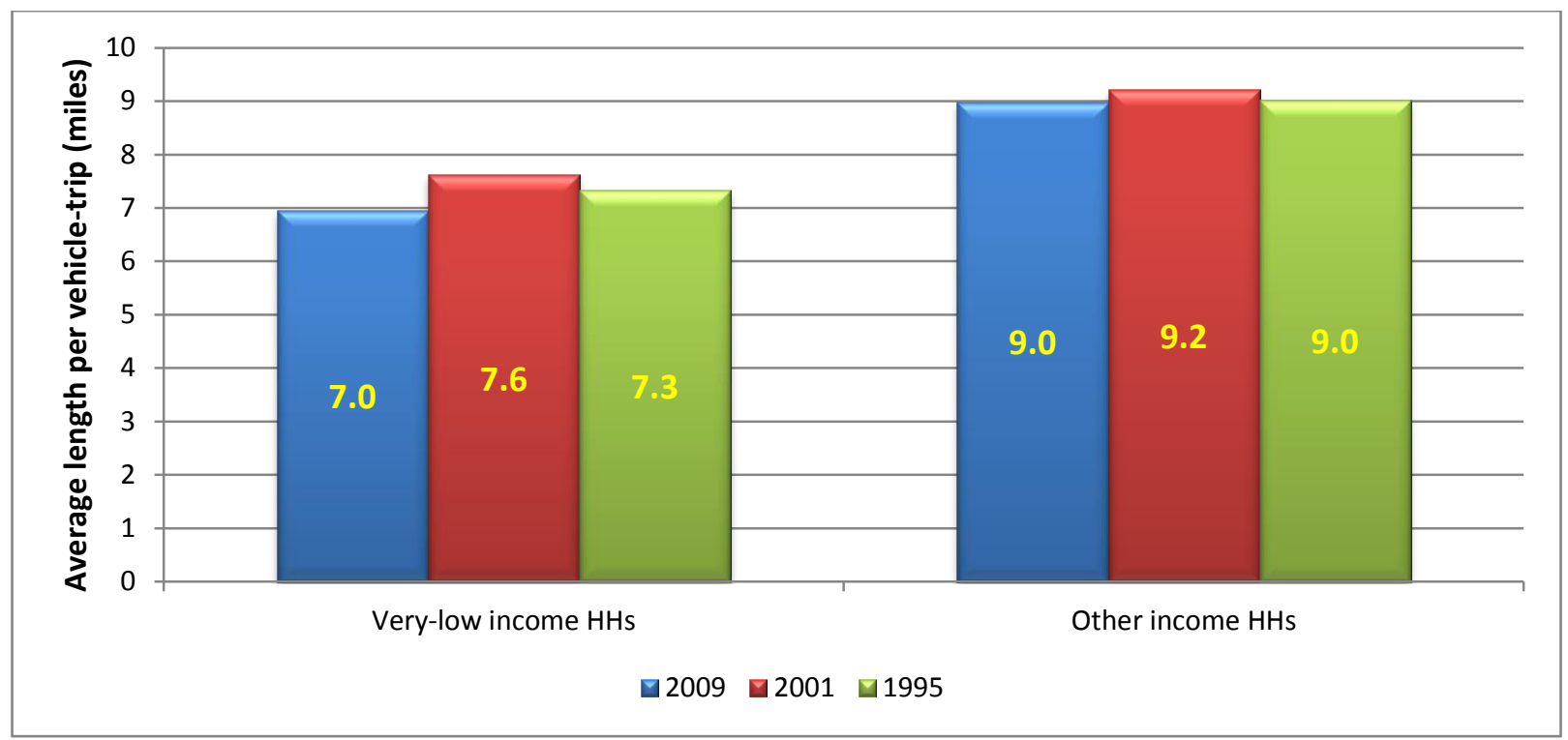

Figure 4-21. Average travel distance (miles) per vehicle-trip made by NYS drivers (NHTS data) 


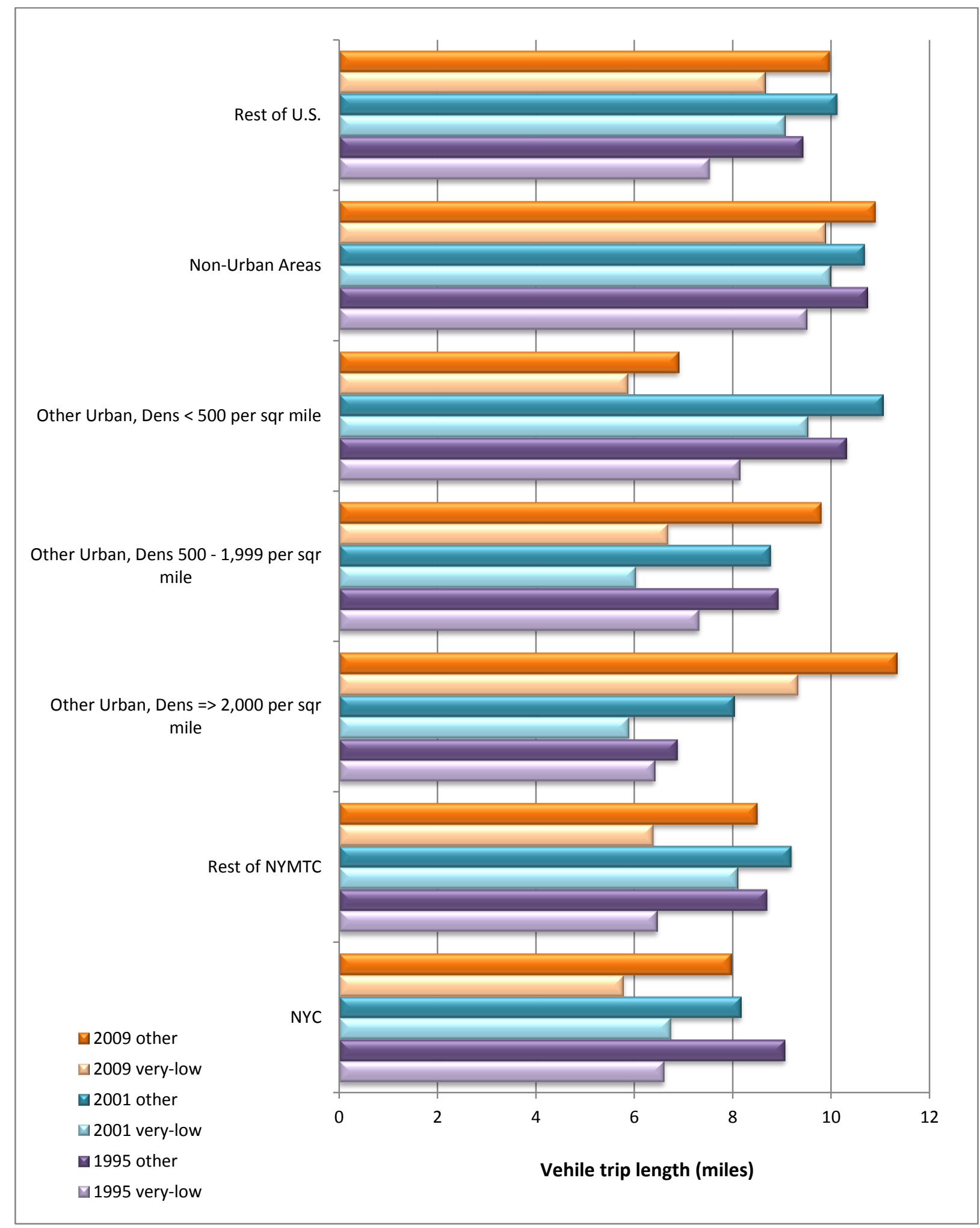

Figure 4-22. Average length of vehicle trips by population density/region and income status $(2009,2001, \&$ 1995 NHTS) 


\subsubsection{Effects of Income on Vehicle-Trip Travel Time}

In addition to travel distance, the total time spent on daily vehicle-trips made by a driver who drove on the NHTS-assigned travel day was also analyzed in this study. Among drivers who drove on their travel day, those from very-low income households spent an average of about 68 minutes daily in vehicles during 2009, as compared to about 76 minutes for their higher income counterpart drivers (Figure 4-23). The similar trend is shown in 1995, but not in 2001 (average time spent in a vehicle per driver for very-low income households is larger than that of other income level households in 2001). The daily time spent in a vehicle decreased since 2001 for drivers with very-low incomes, dropping from 81 minutes in 2001 to 68 minutes in 2009. Such a level of reduction in time was not observed among higher income drivers, however.

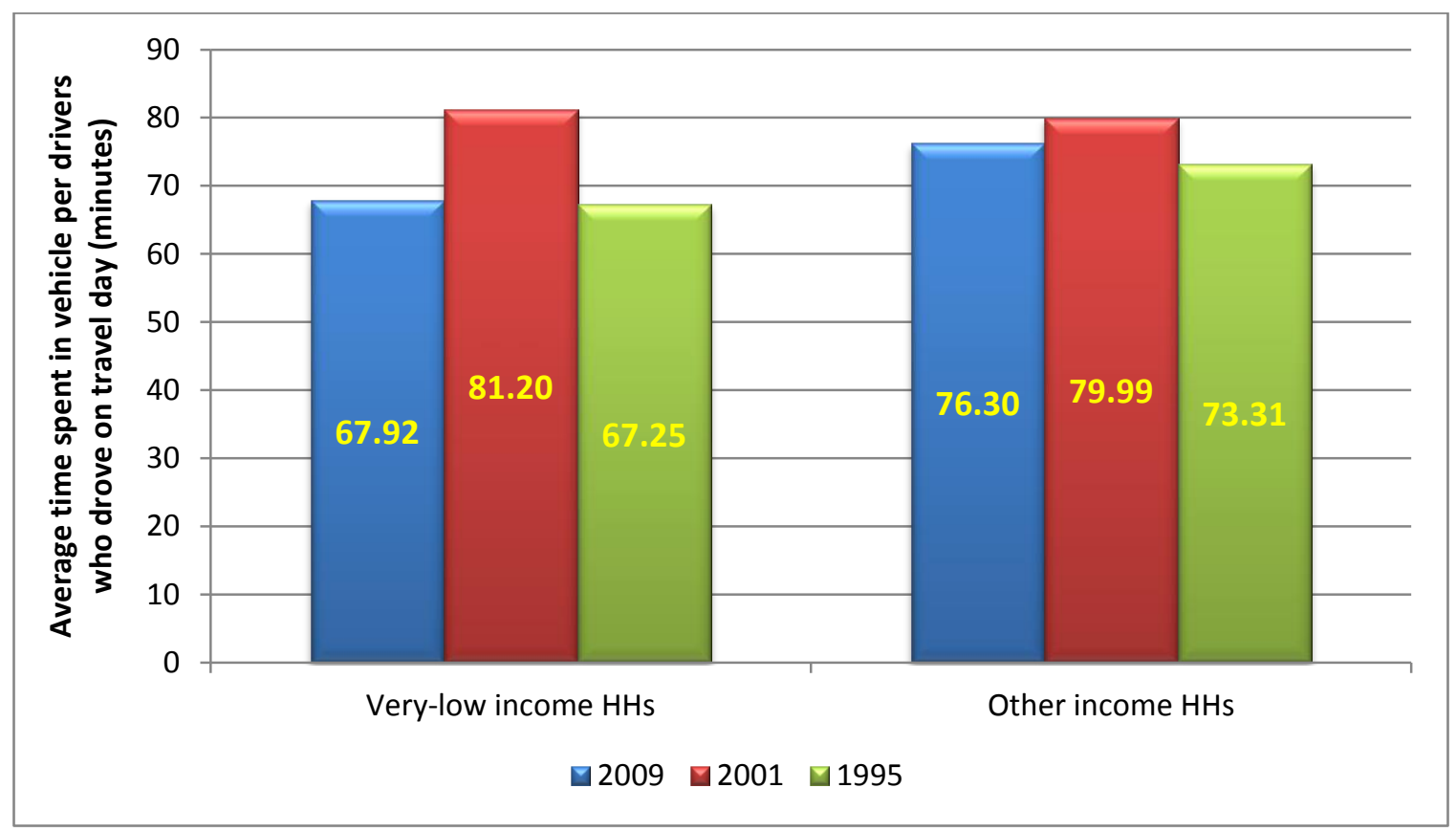

Figure 4-23. Average time spent in vehicle per NYS-driver who drove on travel day (minutes) 



\section{TRANSPORTATION ACCESSIBILITY AND EQUALITY}

\subsection{ACCESSIBILITY TO PUBLIC TRANSPORTATION}

As discussed earlier in this report, mode share for public transit is significantly higher among NYS's very-low income population than that of higher income neighbors. Not surprisingly, Figure 5-1 shows that the majority of very-low income households in NYS were in close proximity to transit stops. Using 2009 NHTS data along with transit data obtained from NYS General Transit Feed Specification (GTFS), over 70\% of NYS very low income population, with ages of 5 years and over (NHTS constraint), lived within a one-mile radius of transit stops.

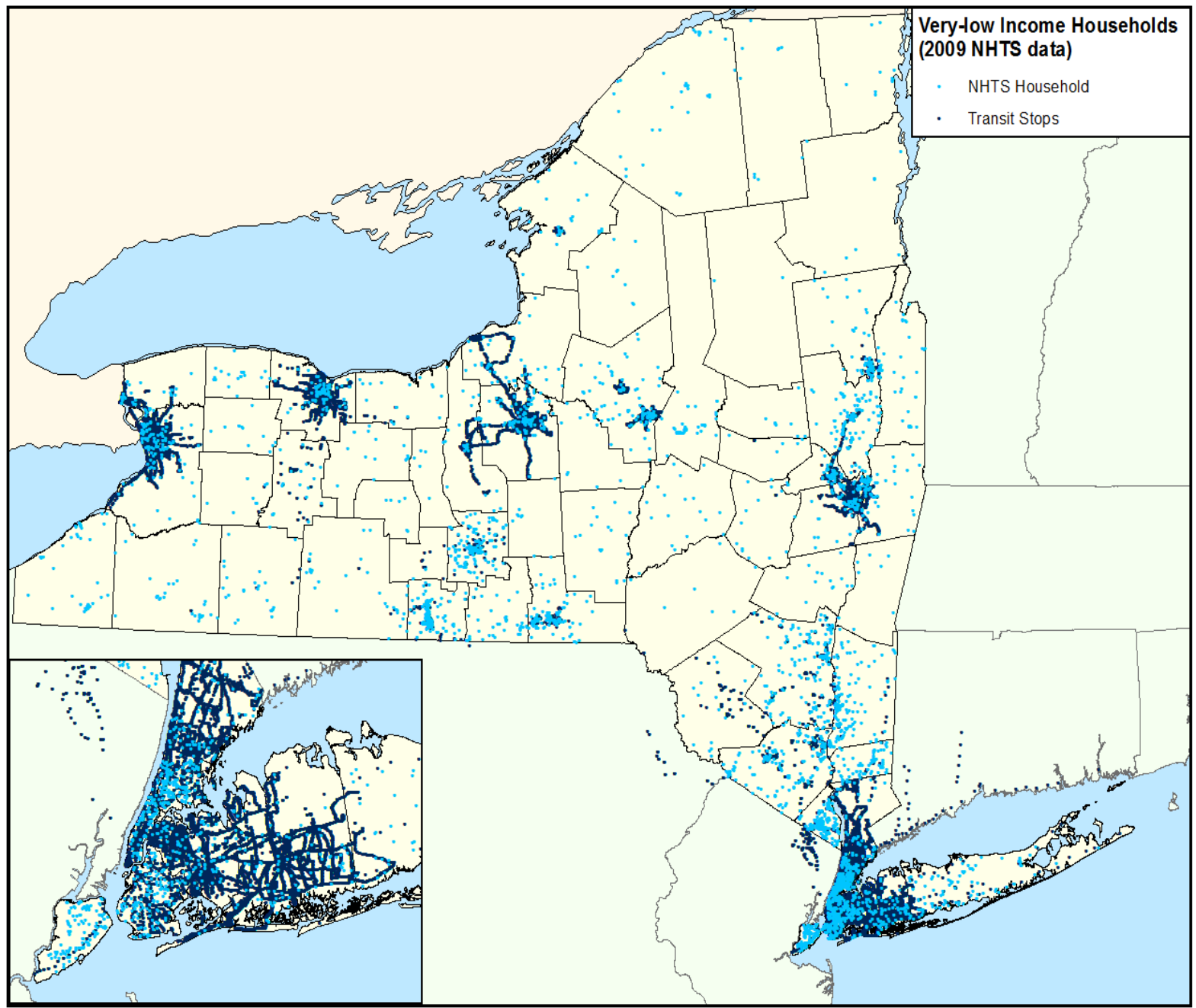

Figure 5-1. Distribution of very-low income households and locations of public transit stops in NYS

Note that a one-mile radius was chosen for this study because this distance is achievable within roughly 20 minutes walking under normal conditions. This one-mile transit stop radius essentially covered $84 \%$ of NYS's very-low income population, while only $17 \%$ of their 
counterpart other income New Yorkers lived within the same range. Clearly, NYS's public transit plays an important role in serving its very-low income population's mobility needs.

\subsubsection{Influence of Income on Public Transit Uses}

Based on the 2009 NHTS, Figure 5-2 indicates that the likelihood of using public transit decreases as the person's household income increases. Nearly $35 \%$ of all persons in NYC with income under $\$ 25,000$ used public transit, compared to $13 \%$ for their neighbors from the $\$ 100,000+$ income households. Moreover, less than $4 \%$ of persons with the lowest income level (under $\$ 25,000$ ) who lived outside of NYC utilized public transit during 2009-likely associated with the availability of (or rather, the lack of) public transit services. Note that Figure 5-2 shows public transit use among NYC residents who did not report their incomes was also significant $(25 \%)$.

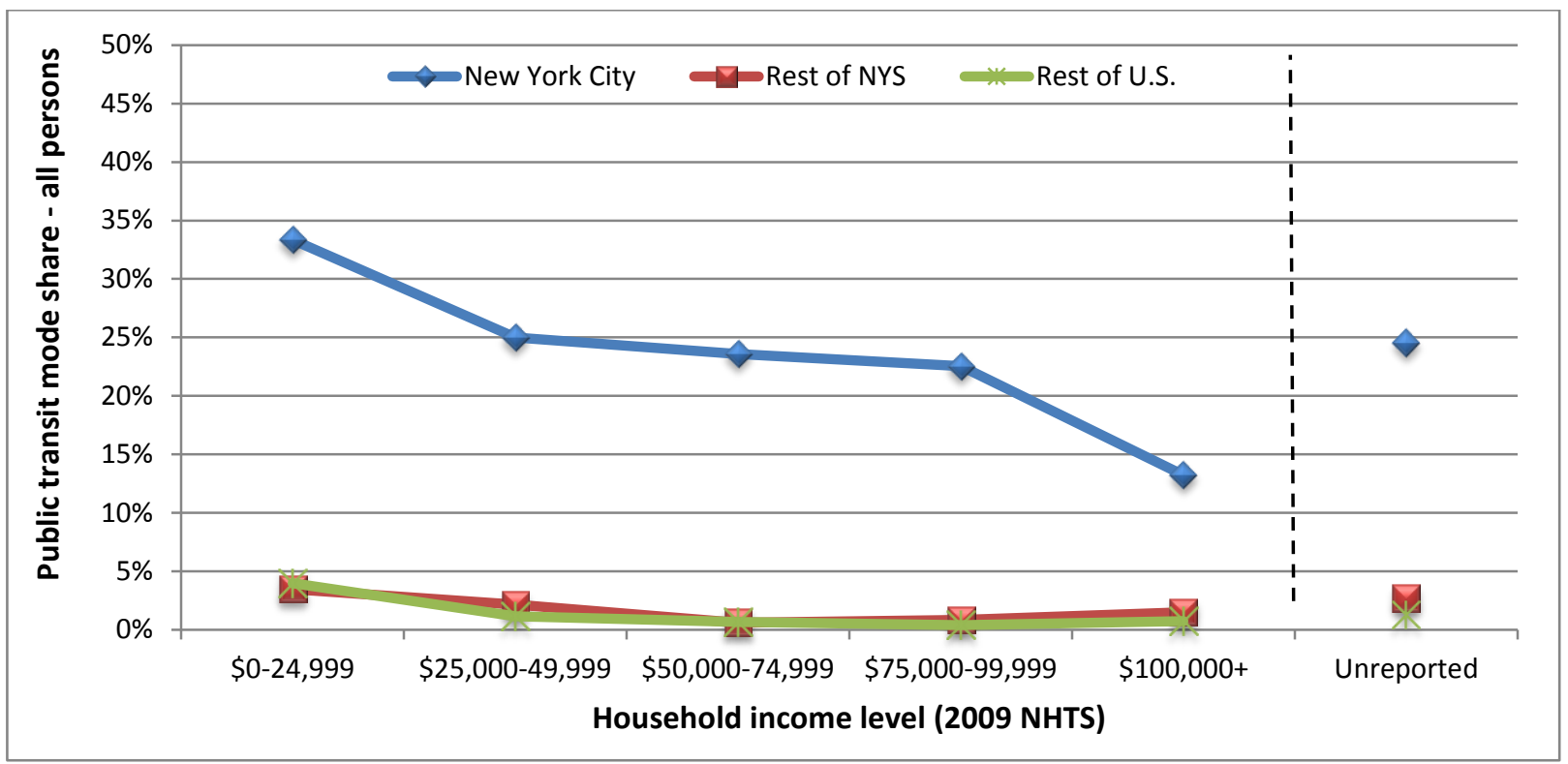

Figure 5-2. Public transit share (all persons age 5 years and over) by income and region (2009 NHTS) ${ }^{15}$

Children (ages 5-15 years old) from the lowest income households (under \$25,000) of NYC had the highest likelihood (46\%) of taking public transit compared to children of higher income households (Figure 5-3). In contrast, only $13 \%$ of children in households with $\$ 100,000$ or more incomes from NYC used public transit during 2009. Outside of NYC, children from other NYS regions and those of the rest of U.S. used public transit similarly, regardless of their income status. Children from the lowest income households residing outside of NYC still show a higher likelihood of taking public transit than those of other households from the same region, $2.4 \%$ versus $0.4 \%$ or under, respectively.

\footnotetext{
${ }^{15}$ Public transit share by income and region for other years, 2001 and 1995, can be obtained from NHTS, but may not be directly comparable due to many factors, such as changes of transit network, overall traffic conditions of NYC, consideration of inflation factor with different income levels.
} 
Unlike the patterns seen in Figures 5-2 (for the entire population) and 5-3 (for children), Figure 5-4 displays a much smoother public transit share pattern for NYC's elderly residents (ages of 65 years and older) over the household income levels. Elderly NYC residents with the lowest income (under $\$ 25,000$ ) still have a higher likelihood of using public transit than their higher income counterpart neighbors, $23 \%$ versus $17 \%$ or lower, respectively.

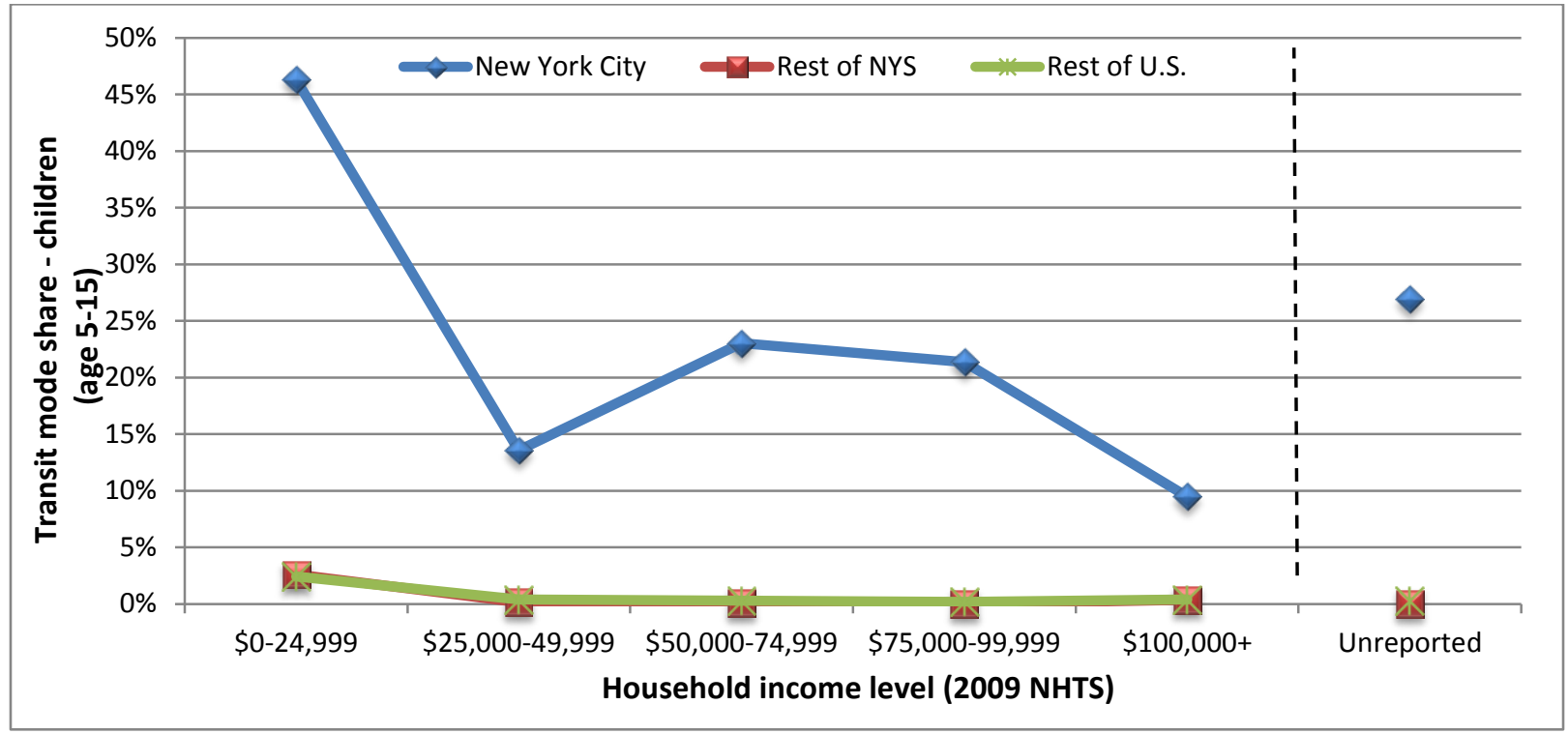

Figure 5-3. Public transit share among children (ages 5-15) by income and region (2009 NHTS)

Clearly visible in Figure 5-4, the gap in public transit mode shares between the poorest and others with higher incomes was much smaller among elderly residents. Interestingly, for New Yorkers who lived in NYC and household incomes of $\$ 100,000$ or more, public transit was an alternate mode of transportation for $17 \%$ of their elderly members.

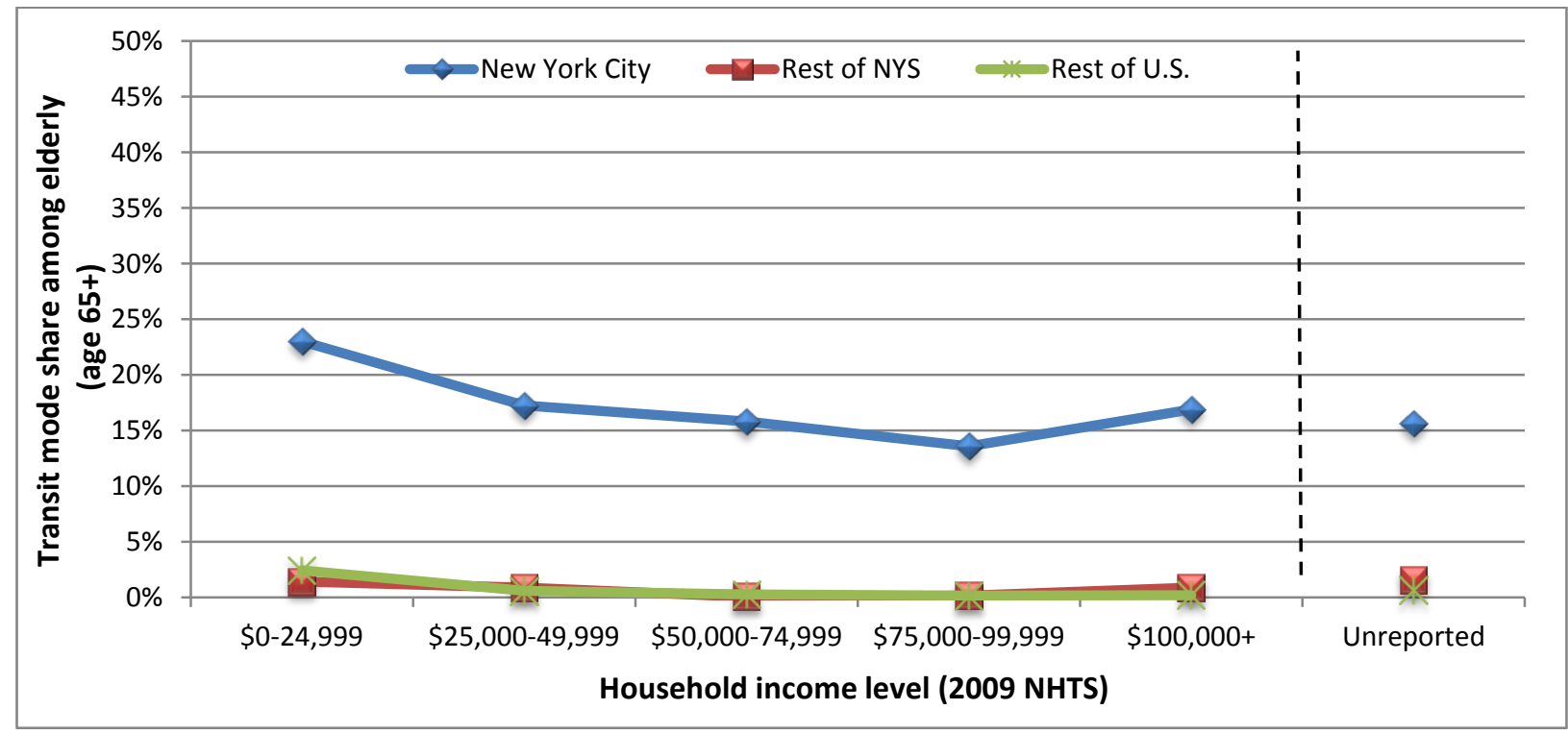

Figure 5-4. Public transit share among elderly residents (65+) by income and region (2009 NHTS) 


\subsubsection{Public Transit Use by Income Status and Trip Purpose}

Most of the public transit trips made by NYS's very-low income households on a daily basis were for family \& personal business purposes in both 2001 and 2009. On the other hand, most of the public transit trips made by their higher income neighbors were for conducting their daily activities for work purposes during the same period. As seen in Figure 5-5, 35\% the daily public transits trips taken by NYS's very-low income residents in 2009 were for family/personal business activities, versus $26 \%$ among their counterpart other income transit-user neighbors. On the contrary, nearly $43 \%$ of public transit trips made by other income New Yorkers were to earn a living (work), as compared to only $23 \%$ among public transit trips taken by their lower income counterpart neighbors. Aside from work trips, however, no significant influence due to trip purpose was found. Figure 5-6 shows that the non-work trip-purpose distributions of daily public transit trips are very similar, regardless of the income level of the travelers.

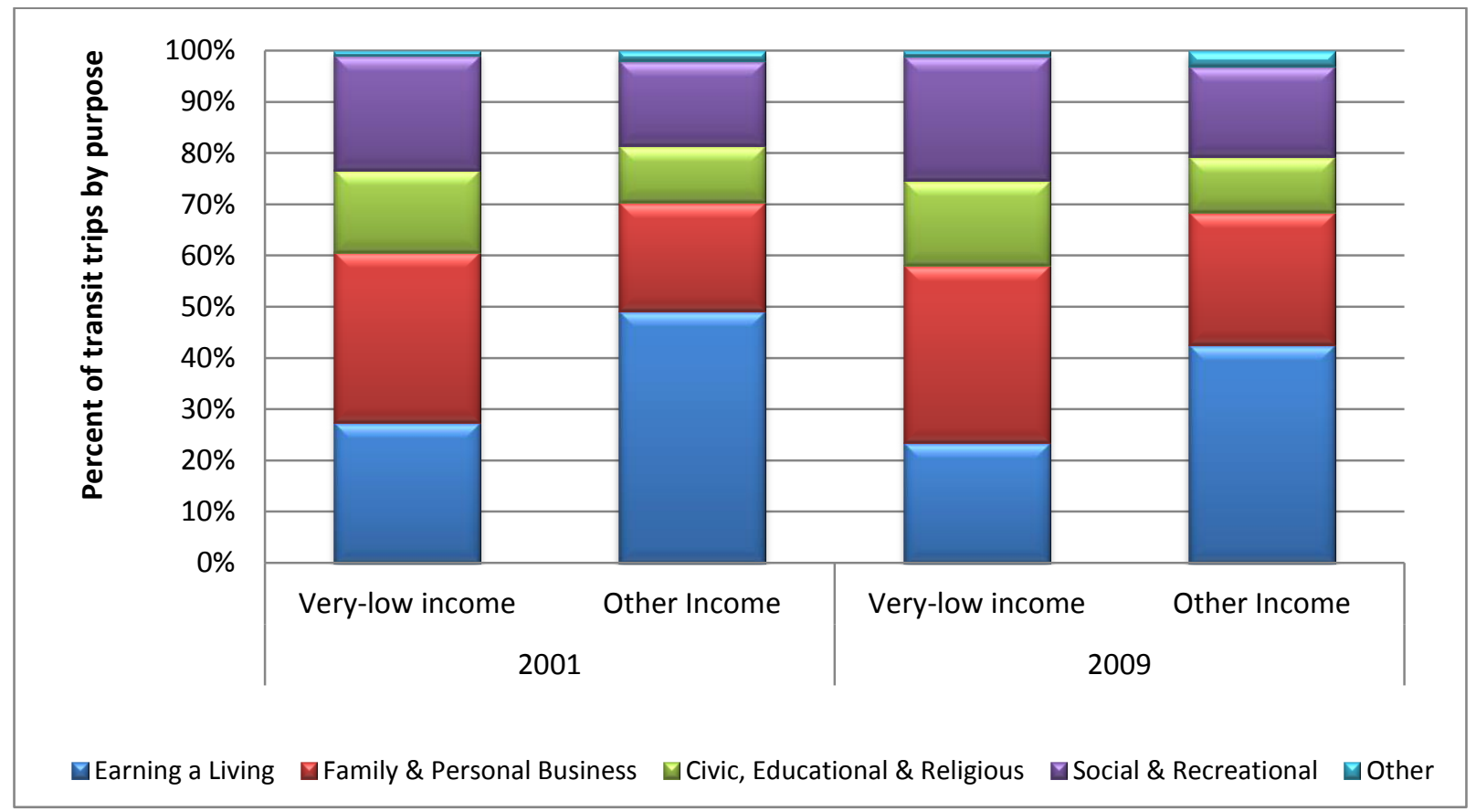

Figure 5-5. Distribution of daily public transit trips by trip purpose and income level in NYS (2009 \& 2001 NHTS) 


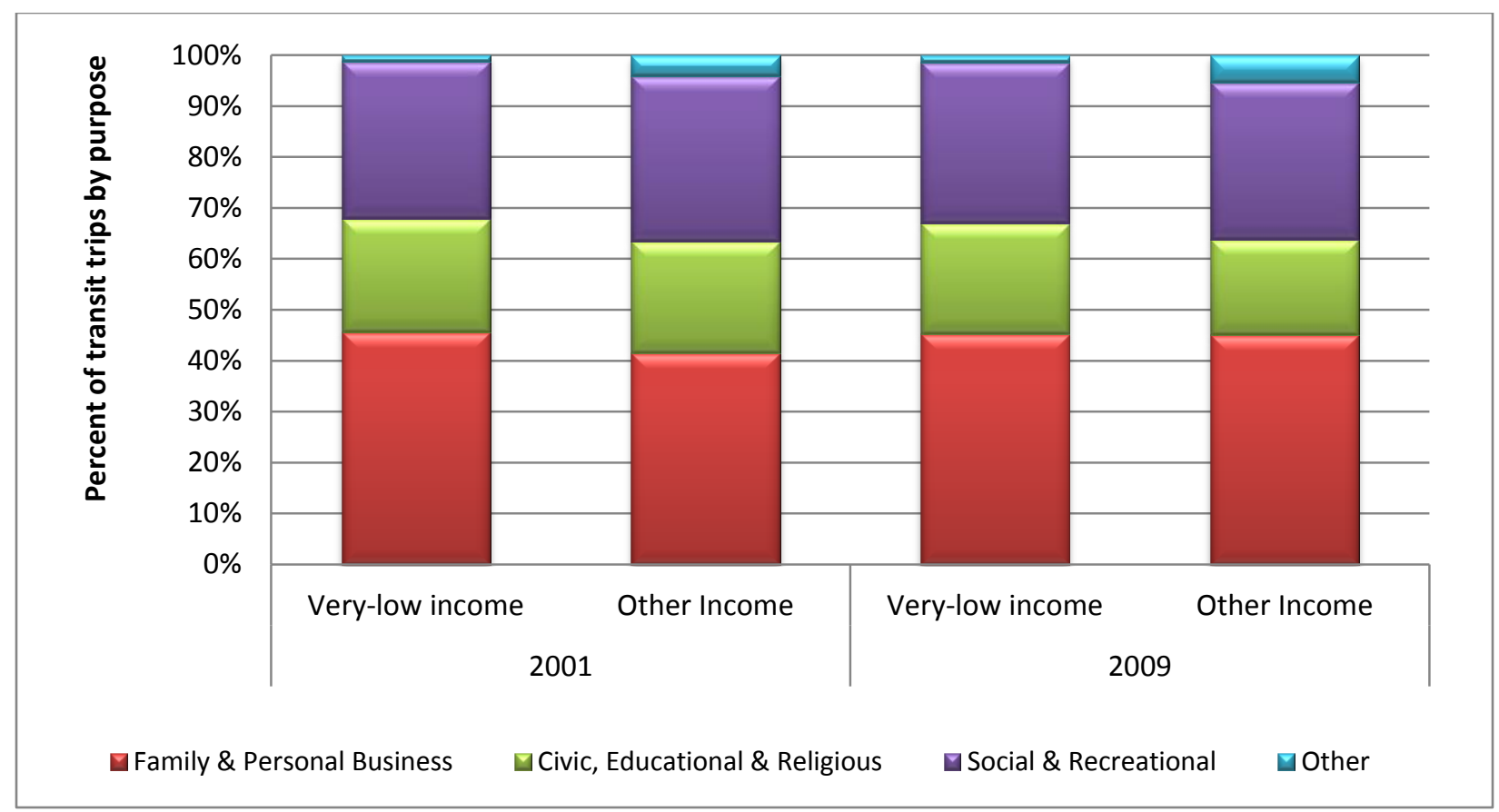

Figure 5-6. Distribution of daily public transit trips by non-work purpose and income for NYS residents (NHTS)

\subsection{WORKER COMMUTE PATTERNS}

\subsubsection{Trip Frequency by Day of the Week Traveled}

Overall, among NYS residents, other income workers made more daily trips than very-low income workers during weekends as well as weekdays (Figure 5-7). The differences during the second half of the weekdays were not as visible, however. When focusing on commute trips (Figure 5-8), a very-low income worker appears to make slightly more daily commute trips compared to his/her other income counterpart during the Friday-Sunday period. This might be attributed to lower income workers who are more likely to be employed by lower-paying service sector jobs, which tend to require more help during the weekends (including Friday nights). 


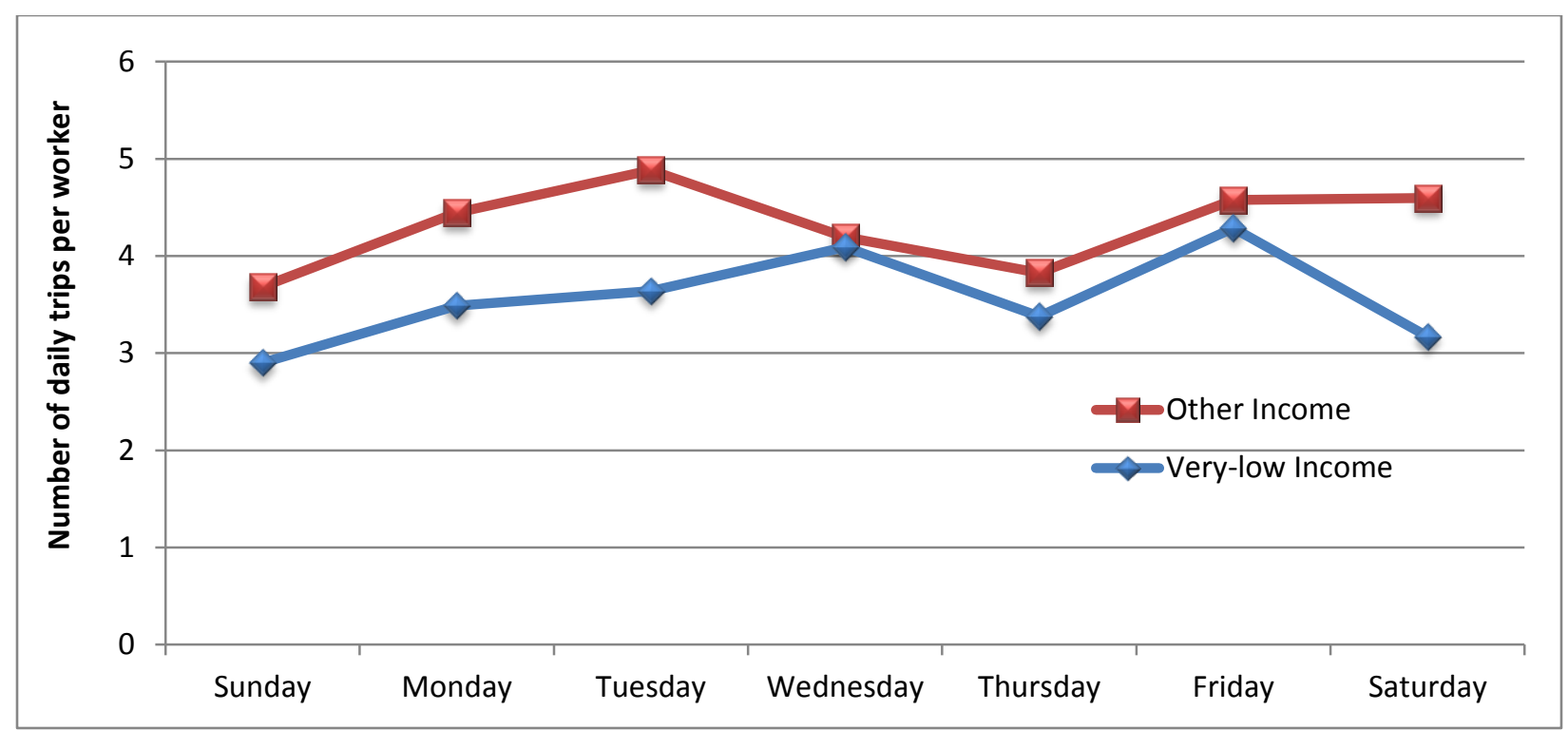

Figure 5-7. Average number of daily person-trips per worker by income status for NYS residents (2009 NHTS)

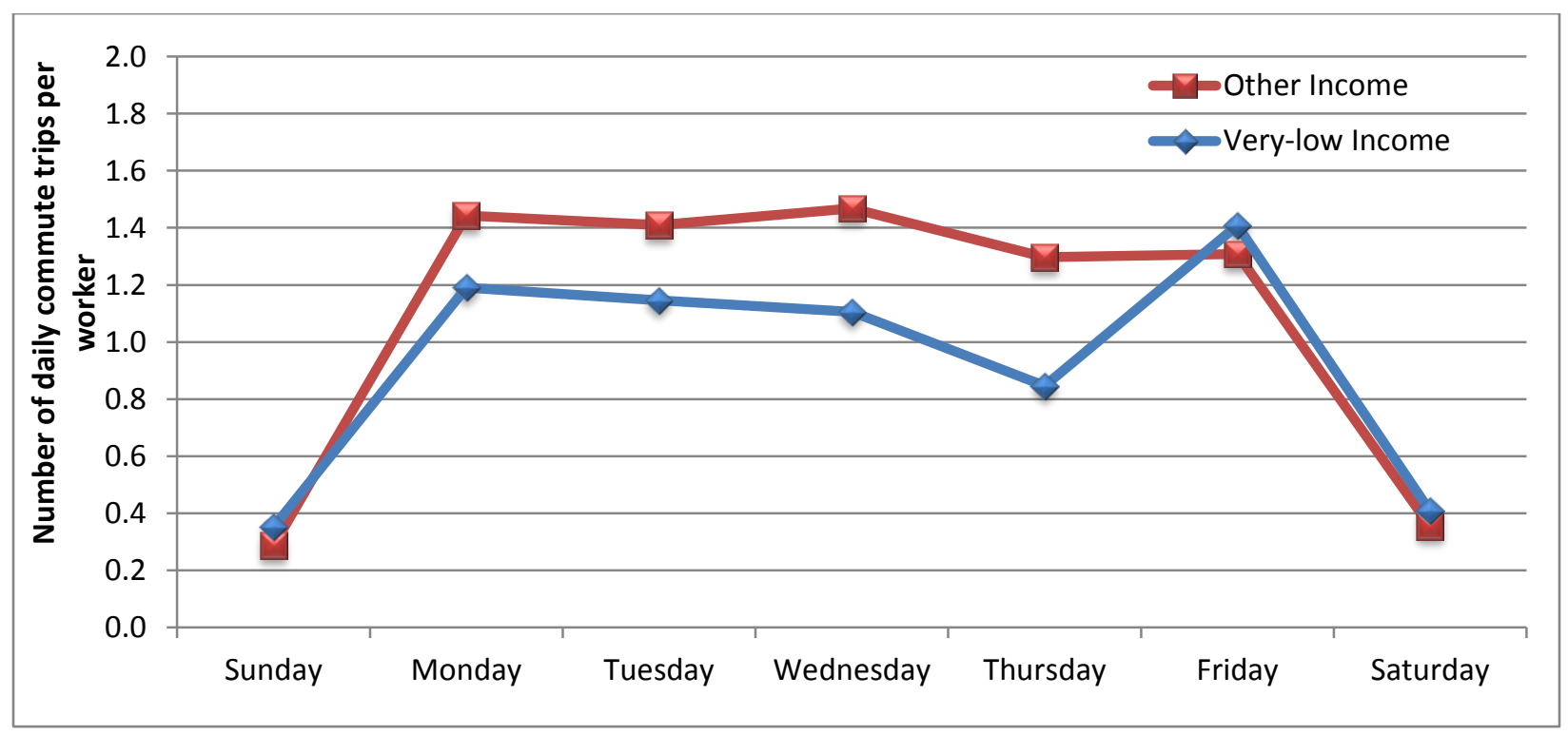

Figure 5-8. Average number of daily commute trips per worker by income status for NYS residents (2009 NHTS)

Figure 5-9 shows that the shares of commute trips were slightly higher for a very-low income worker on most days, except for Wednesday and Thursday. On average, roughly one-third of daily trips made by a very-low income worker during weekdays were for work (Figure 5-9). Weekend commute trips accounted for less than $8 \%$ of daily trips made by an other income worker, compared to about $12-13 \%$ of daily trips made by a very-low income worker.

Due to sample size limitations, however, these estimates were subjected to higher uncertainties - i.e., with a wider range of standard errors, thus not as precise. Consequently, the 
impacts of income status on the average number of daily trips (as well as commute trips) made by NYS workers, during 2009, were inconclusive.

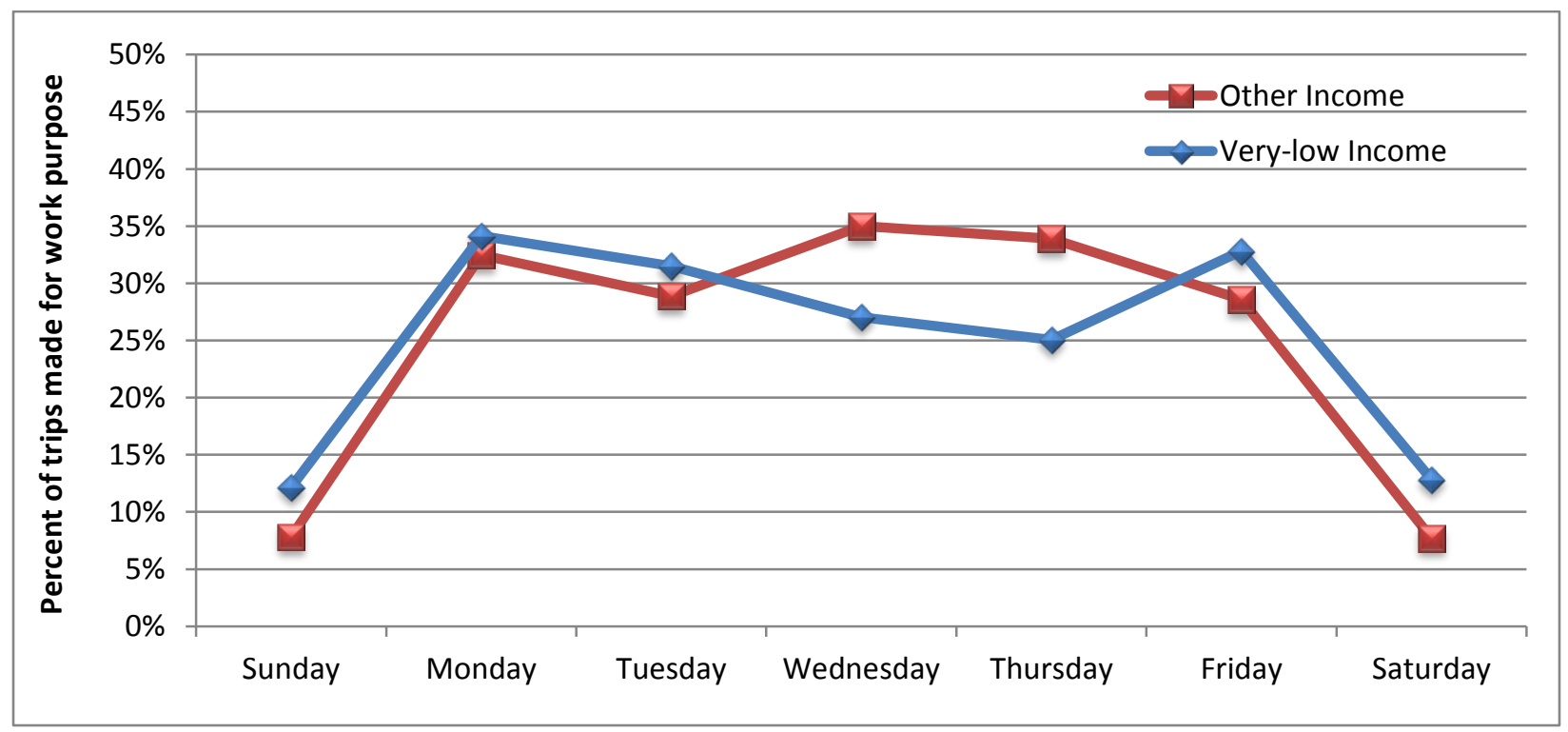

Figure 5-9. Percent of daily person trips made for work purpose by income status for NYS

\subsubsection{Length of POV Commute-Trip by Population Density}

Summarized in Figure 5-10, workers from very-low income households typically traveled shorter distances in POVs for their commute trips than those made by workers from higher income households in 2009, regardless of where they lived. The only exception is for workers who lived in the highly populated urban areas $(25,000+$ in population density), where a very-low income worker traveled an average of 3 miles farther in POV commute trips than his/her counterpart from other income households (Figure 5-10).

In addition, Figure 5-10 shows no visible differences in trip length (in miles) for commutetrips made in POVs between other income NYS workers and those from the rest of U.S., with respect to the population density of their resident locations (see green and purple lines in Figure 5-10). However, this chart clearly shows that POV commute-trip lengths among other income workers, on average, decreases as the population density in which they resided increases.

The average commute-trip length by POVs for workers from a very-low income household in NYS (blue line in Figure 5-10) also displays a declining trend as the population density (in which they lived) increases. However, as pointed out above, average commute-trip length on POVs for those who lived in the highest density place (including NYC) does not follow that trend. Similarly, workers from very-low income households who lived in the rest of U.S., on average, traveled slightly longer distances in a POV for their daily commute trips, especially for those who lived in less dense locations (i.e., rural or small urban areas). 


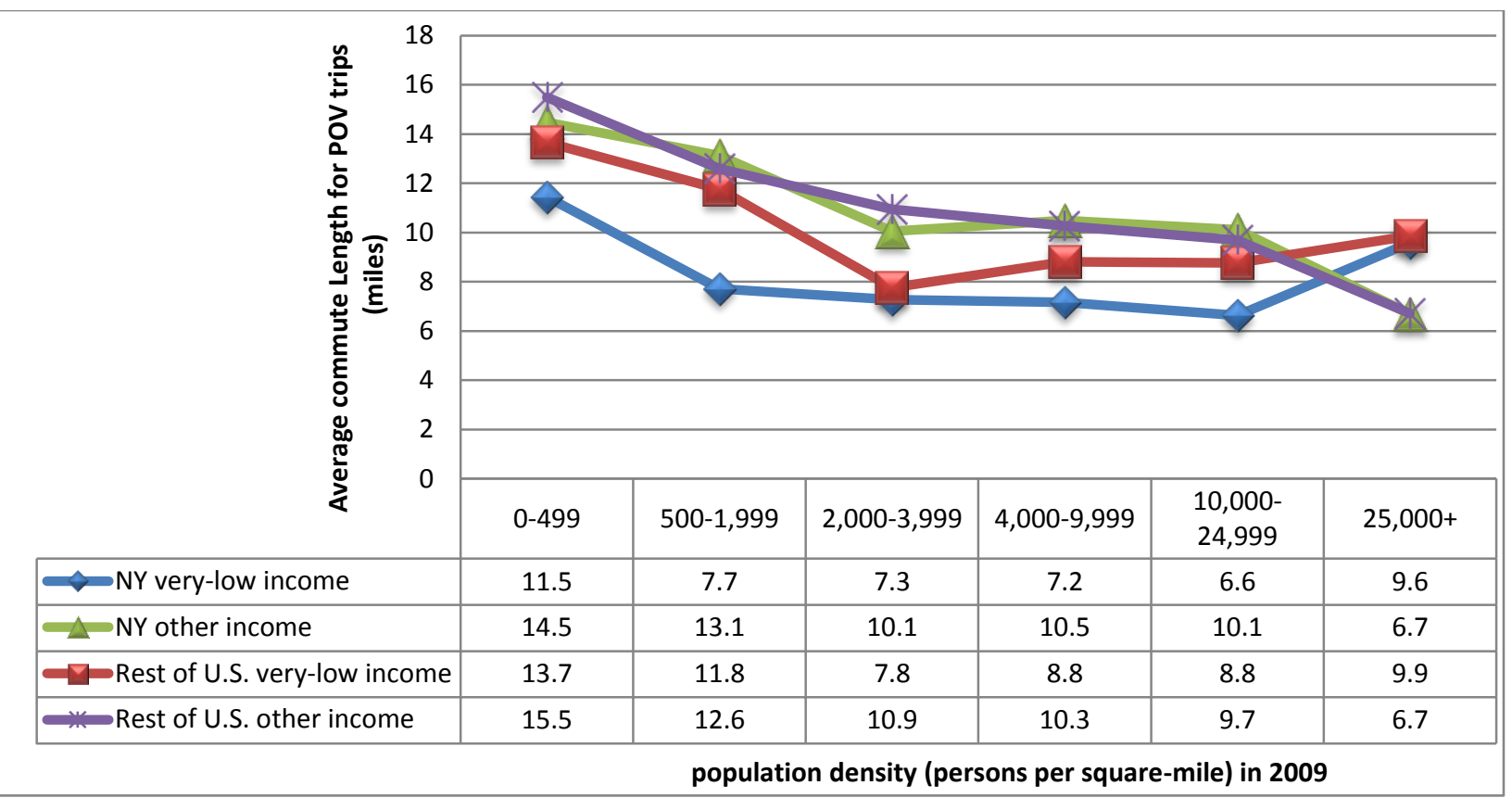

Figure 5-10. Average POV commute-trip length (in miles) by income status, population density, and region in 2009

Table 5-1 summarizes workers' daily commute statistics with respect to their modes of transportation used for commuting (POV, public transit, walk, and other), by their income status and population density for the areas in which they lived during 2009. Based on the average commute length statistics presented in Table 5-1, it is clearly visible that, in most non-walking cases, an other income worker traveled a longer commute-trip than one from a very-low income household, except for those who lived in a highly-populated areas (i.e., 25,000+ in population density). 
Table 5-1. Commute statistics by mode, population density, and household income status in 2009 (2009 NHTS)

\begin{tabular}{|c|c|c|c|c|c|c|c|c|c|c|c|c|}
\hline \multirow{3}{*}{$\begin{array}{c}\text { Mode of } \\
\text { Transportation for } \\
\text { Commute Trips }\end{array}$} & \multicolumn{12}{|c|}{ Population Density (Population per square mile) } \\
\hline & \multicolumn{2}{|c|}{$<500$} & \multicolumn{2}{|c|}{$500-1,999$} & \multicolumn{2}{|c|}{$2,000-2,999$} & \multicolumn{2}{|c|}{$4,000-9,999$} & \multicolumn{2}{|c|}{$10,000-24,999$} & \multicolumn{2}{|c|}{$25,000+$} \\
\hline & NYS & U.S. & NYS & U.S. & NYS & U.S. & NYS & U.S. & NYS & U.S. & NYS & U.S. \\
\hline \multicolumn{13}{|c|}{ Average Commute Length (miles) } \\
\hline \multicolumn{13}{|c|}{ Very-low-income Persons } \\
\hline Private vehicle & 10.0 & 13.4 & 9.9 & 11.9 & 6.9 & 9.1 & 7.7 & 9.3 & 5.9 & 10.5 & 21.4 & 13.2 \\
\hline Public Transit & 8.2 & 5.3 & 2.0 & 9.3 & 4.3 & 5.5 & 6.1 & 8.8 & 8.3 & 6.3 & 6.9 & 9.9 \\
\hline Other & 7.8 & 3.8 & 7.2 & 6.5 & 6.6 & 5.0 & 2.8 & 6.4 & 18.3 & 3.2 & 6.0 & 10.0 \\
\hline Walk & 0.4 & 0.7 & 2.0 & 3.3 & 0.5 & 0.8 & 1.2 & 1.0 & 0.4 & 1.0 & 0.7 & 0.6 \\
\hline \multicolumn{13}{|c|}{ Other-income Persons } \\
\hline Private vehicle & 15.1 & 15.0 & 11.8 & 12.6 & 11.2 & 10.8 & 10.6 & 10.2 & 9.0 & 9.7 & 9.7 & 8.9 \\
\hline Public Transit & 21.9 & 7.0 & 29.4 & 27.3 & 29.1 & 19.7 & 16.1 & 12.7 & 13.3 & 8.4 & 7.7 & 5.3 \\
\hline Other & 88.7 & 46.4 & 9.5 & 35.2 & 2.9 & 15.5 & 4.6 & 10.4 & 33.8 & 11.6 & 3.4 & 4.2 \\
\hline Walk & 0.6 & 0.5 & 1.1 & 0.6 & 0.5 & 0.8 & 0.7 & 0.8 & 0.9 & 1.0 & 2.2 & 0.7 \\
\hline \multicolumn{13}{|c|}{ Commute Travel Time (minutes) } \\
\hline \multicolumn{13}{|c|}{ Very-low-income Persons } \\
\hline Private vehicle & 18.7 & 22.8 & 19.4 & 23.7 & 18.0 & 19.8 & 22.0 & 21.1 & 18.8 & 27.5 & 49.5 & 31.5 \\
\hline Public Transit & 42.0 & 58.7 & 27.8 & 45.7 & 33.5 & 47.6 & 34.8 & 55.8 & 45.7 & 49.1 & 53.7 & 57.0 \\
\hline Other & 27.4 & 18.4 & 21.6 & 18.2 & 14.6 & 28.8 & 22.4 & 29.4 & 41.6 & 18.9 & 39.1 & 24.4 \\
\hline Walk & 6.0 & 10.9 & 14.4 & 17.7 & 10.0 & 16.9 & 20.7 & 17.8 & 16.2 & 16.6 & 15.6 & 14.0 \\
\hline \multicolumn{13}{|c|}{ Other-income Persons } \\
\hline Private vehicle & 24.9 & 23.7 & 23.0 & 22.4 & 22.4 & 22.1 & 24.7 & 22.1 & 25.2 & 23.5 & 31.2 & 27.3 \\
\hline Public Transit & 63.4 & 39.8 & 70.4 & 59.6 & 70.9 & 79.4 & 61.4 & 48.6 & 69.8 & 51.6 & 48.0 & 47.3 \\
\hline Other & 36.8 & 24.9 & 41.6 & 26.7 & 18.4 & 38.1 & 22.6 & 30.9 & 42.2 & 23.8 & 21.6 & 22.6 \\
\hline Walk & 9.8 & 8.6 & 14.5 & 25.1 & 15.6 & 17.4 & 14.8 & 12.9 & 19.0 & 14.5 & 20.9 & 12.8 \\
\hline \multicolumn{13}{|c|}{ Average Commute Speed (miles per hour) } \\
\hline \multicolumn{13}{|c|}{ Very-low-income Persons } \\
\hline Private vehicle & 32.2 & 35.2 & 30.5 & 30.1 & 23.1 & 27.5 & 20.9 & 26.3 & 18.8 & 23.0 & 25.9 & 25.1 \\
\hline Public Transit & 11.8 & 5.4 & 4.3 & 12.2 & 7.7 & 6.9 & 10.6 & 9.4 & 10.9 & 7.7 & 7.7 & 10.4 \\
\hline Other & 17.2 & 12.4 & 20.1 & 21.4 & 27.2 & 10.4 & 7.5 & 13.0 & 26.4 & 10.0 & 9.2 & 24.7 \\
\hline Walk & 4.4 & 3.7 & 8.4 & 11.4 & 2.8 & 2.7 & 3.4 & 3.3 & 1.5 & 3.5 & 2.9 & 2.7 \\
\hline \multicolumn{13}{|c|}{ Other-income Persons } \\
\hline Private vehicle & 36.4 & 38.1 & 30.6 & 33.7 & 29.9 & 29.3 & 25.7 & 27.8 & 21.4 & 24.7 & 18.7 & 19.5 \\
\hline Public Transit & 20.8 & 10.6 & 25.0 & 27.5 & 24.6 & 14.9 & 15.8 & 15.7 & 11.4 & 9.7 & 9.6 & 6.7 \\
\hline Other & 144.5 & 112.0 & 13.7 & 79.2 & 9.3 & 24.5 & 12.2 & 20.2 & 48.1 & 29.3 & 9.6 & 11.2 \\
\hline Walk & 3.6 & 3.6 & 4.5 & 1.5 & 2.0 & 2.7 & 3.0 & 3.8 & 2.8 & 4.2 & 6.3 & 3.1 \\
\hline
\end{tabular}

Note: Yellow shaded cells are based on small samples. 


\subsubsection{Average Commute Travel Time}

Included in Table 5-1 are summaries of commute trips by travel time (in minutes) for a worker's daily trip with respect to the mode used, income level, and population density of the region where the worker lived in 2009. Typically, a worker spent less time on commute trips made by POVs as compared to commuting by other non-walk modes, regardless of income status or regions. Workers taking public transit, on the other hand, generally spent the most time commuting.

Furthermore, Figure 5-11 demonstrates no significant differences in commute travel time on POVs (in minutes) between very-low income workers and those from other income households, regardless of population density of the areas they lived. Again, due to relatively large sample variations in these travel time estimates, no conclusions on any impacts due to income levels for commute travel time could be drawn. Note that a summary table on standard errors associated with estimates provided in Table 5-1 is included in Appendix B of this report as a reference.

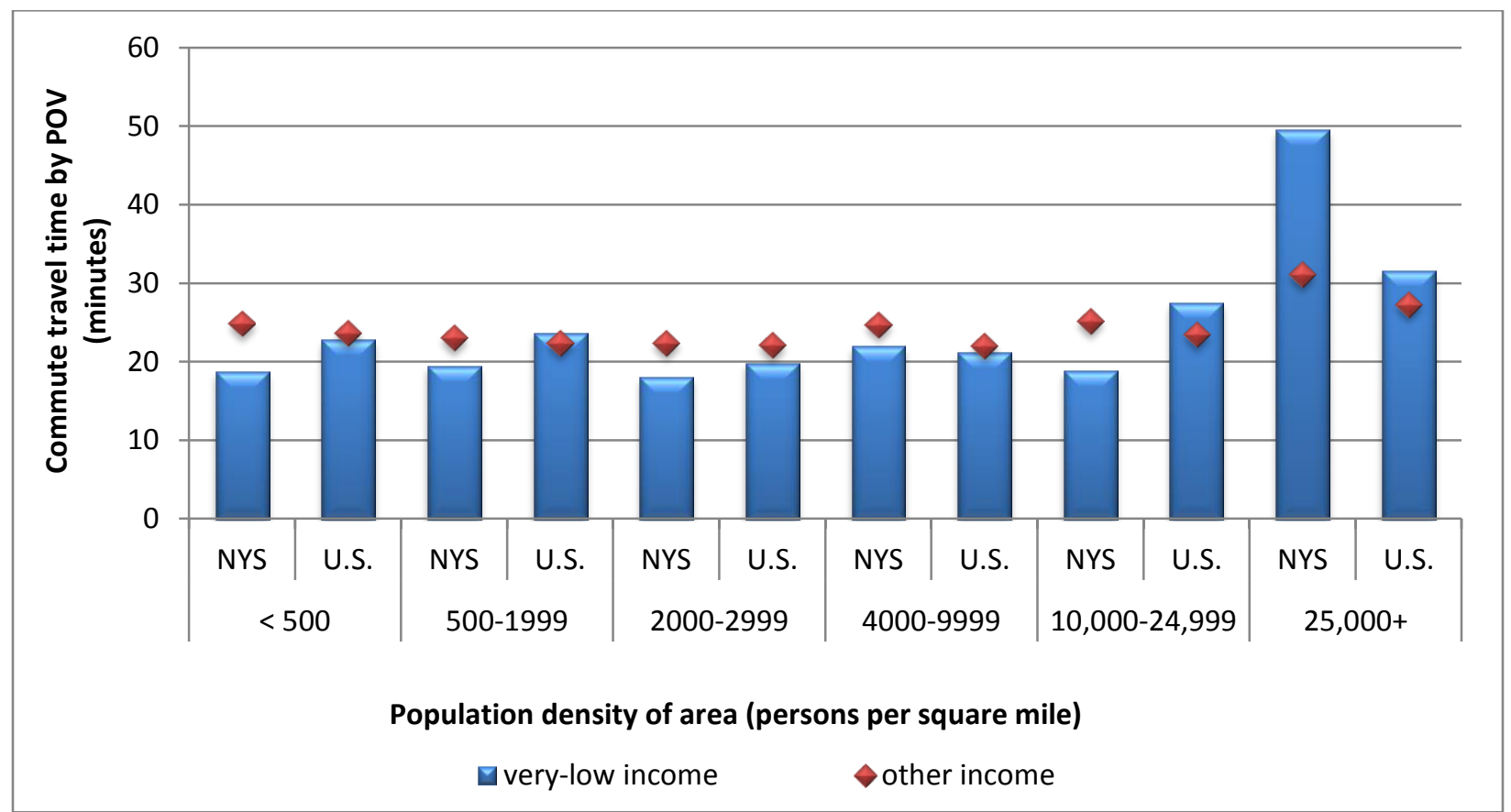

Figure 5-11. Commute travel time per worker for POV trips by income status and population density (2009 NHTS)

A similar display of a worker's daily commute travel time on public transit during 2009, by income and region (measured by population density), is presented in Figure 5-12. As seen from statistics presented in Table 5-1, along with their associated standard errors in Appendix Table B-8, most of these cells were subjected to relatively wide range of errors. This clearly indicates higher degrees of uncertainties on the estimates. Therefore, impacts due to income status, and/or population density, on worker's commuting behavior using public transit were also inconclusive. 


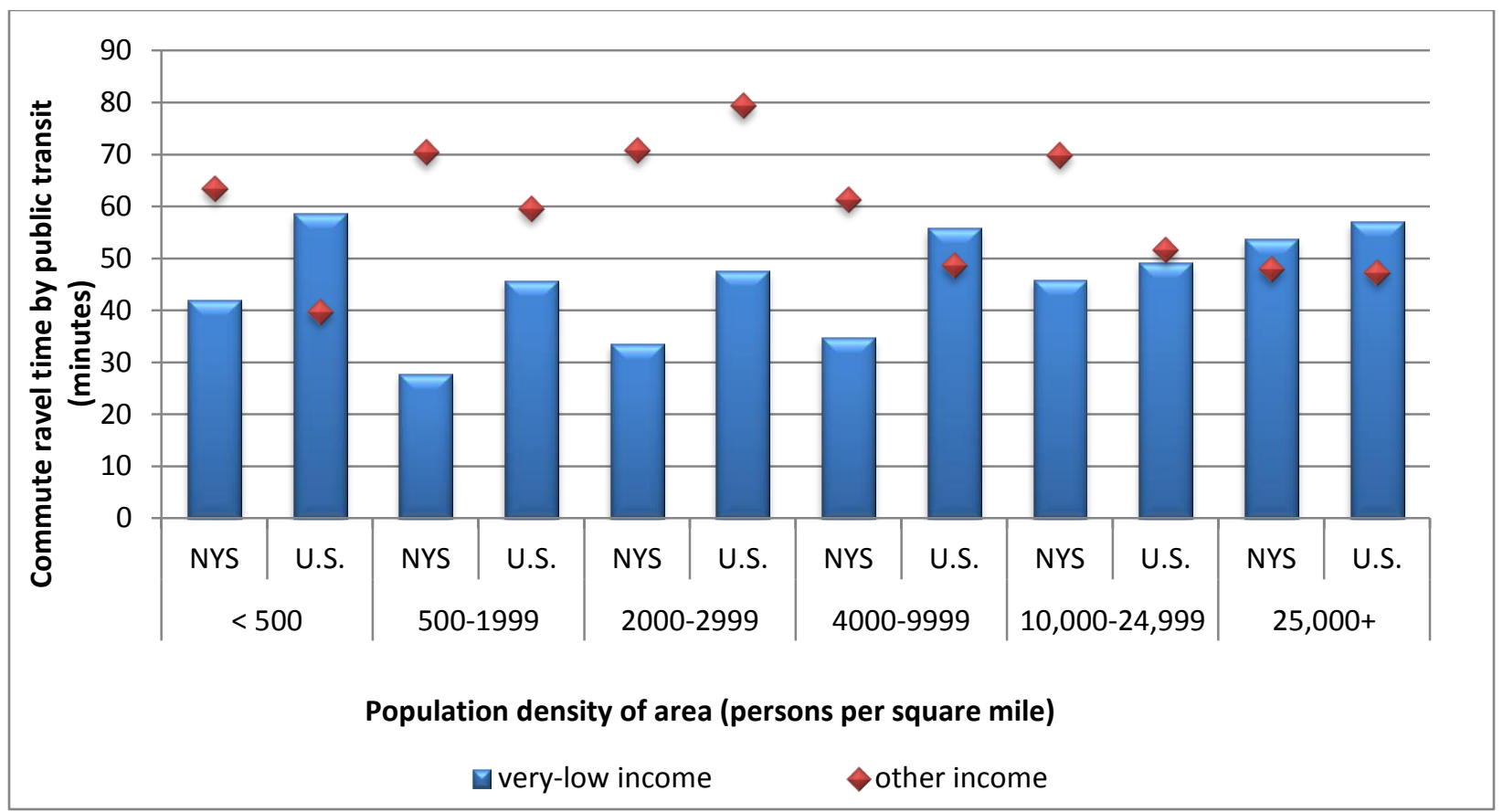

Figure 5-12. Commute travel time per worker for trips made using public transit during 2009 by income status and population density (2009 NHTS)

\subsection{LOW-INCOME ZERO-VEHICLE HOUSEHOLDS}

\subsubsection{Effect on Mode Shares}

As pointed out earlier in this report (Figure 3-12), about $50 \%$ of the very-low income households in NYS did not own any vehicles, compared to only $20 \%$ in the rest of the U.S. Most of these zero-vehicle households in NYS were located in NYC. Regardless of income status, a very-low income New Yorker is more likely to not have traveled and made fewer, as well as shorter, daily trips than a counterpart from other income households in any given day (Table $5-2)$.

Walking is a primary mode of transportation for persons from very-low income with zerovehicle households. Specifically, most person-trips taken by individuals from zero-vehicle households within Manhattan in 2009 were made by walking (Figure 5-13), and accounted for $62 \%$ of all person-trips taken regardless of income status. Outside of NYS, $37 \%$ of person-trips taken by residents from very-low income zero-vehicle households were also walking.

Although POV is the most frequently used mode of transportation among individuals from other income zero-vehicle households who lived in NYS urban areas outside NYC (40\%), still nearly one in four (24\%) of their trips were made by walking (Figure 5-13). In addition, public transit was another primary mode used by those from zero-vehicle households in NYC, for both income groups. The POV use was more significant for zero-vehicle households residing in rural areas of NYS and the rest of U.S., regardless of household income status. 
Table 5-2. Mobility statistics for NYS residents with/without access to vehicle (2009 NHTS)

\begin{tabular}{|c|c|c|}
\hline \multirow[b]{2}{*}{ Mobility Measures } & \multicolumn{2}{|c|}{2009} \\
\hline & $\begin{array}{c}\text { Zero-Vehicle } \\
\text { Households }\end{array}$ & $\begin{array}{c}\text { Households } \\
\text { With Vehicles }\end{array}$ \\
\hline \multicolumn{3}{|l|}{ Percent person did not travel on travel day } \\
\hline Very-low-income & $19.9 \%$ & $14.9 \%$ \\
\hline Other-income & $15.6 \%$ & $11.5 \%$ \\
\hline \multicolumn{3}{|l|}{ Avg. PT/person } \\
\hline Very-low-income & 2.81 & 3.33 \\
\hline Other-income & 3.77 & 3.97 \\
\hline$\%$ difference between income groups & $-25.4 \%$ & $-16.2 \%$ \\
\hline \multicolumn{3}{|l|}{ Average PMT/person } \\
\hline Very-low-income & 6.46 & 19.99 \\
\hline Other-income & 13.59 & 34.42 \\
\hline$\%$ difference between income groups & $-52.4 \%$ & $-41.9 \%$ \\
\hline \multicolumn{3}{|l|}{ Average Person trip length } \\
\hline Very-low-income & 2.74 & 6.58 \\
\hline Other-income & 3.90 & 8.87 \\
\hline$\%$ difference between income groups & $-29.8 \%$ & $-25.8 \%$ \\
\hline
\end{tabular}

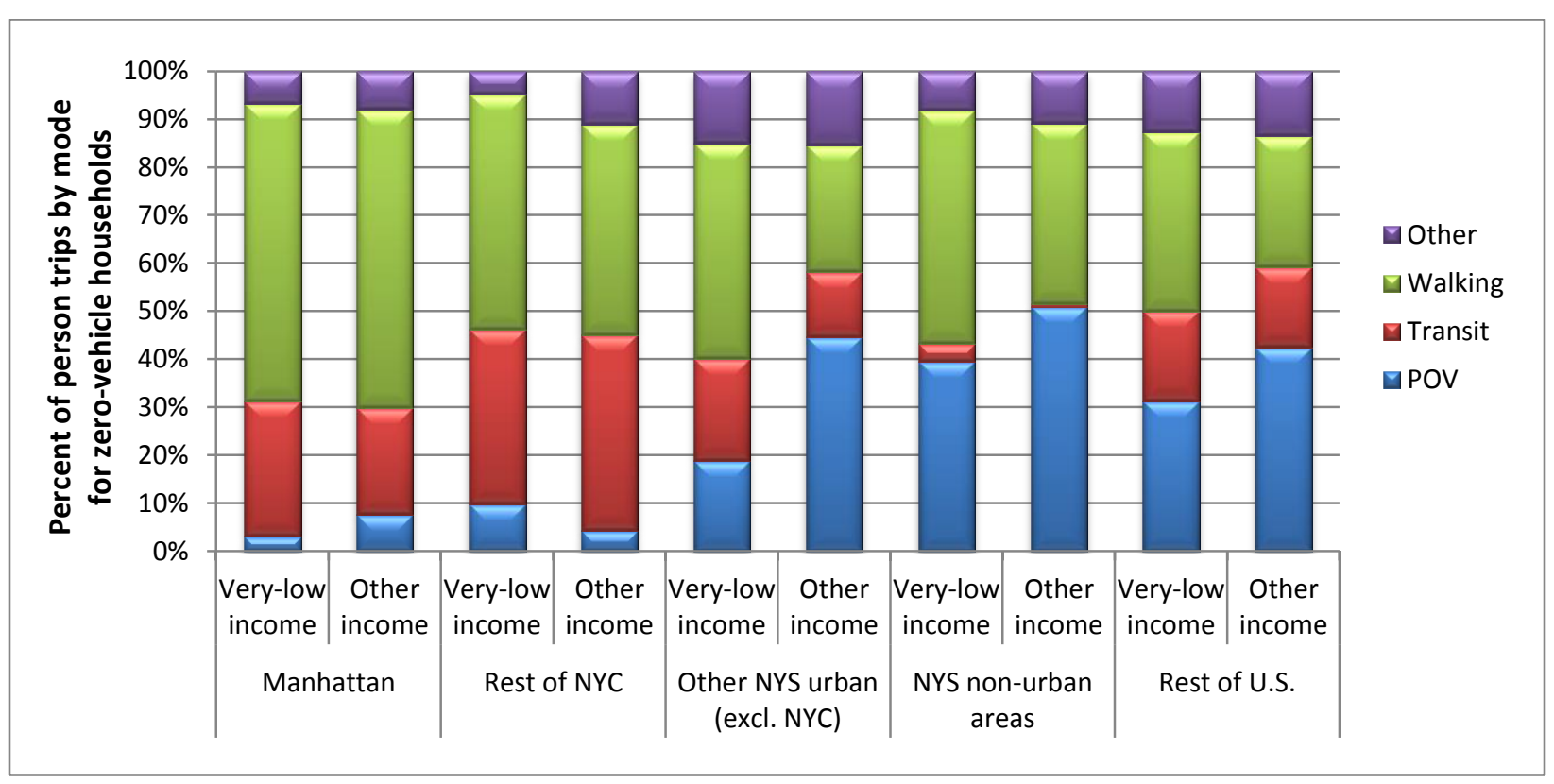

Figure 5-13. Mode shares of person-trips for zero-vehicle households, by income status and region (2009 NHTS)

In addition, Figure 5-14 compares the above mode share patterns over time between 2001 and 2009. There is a clear increase in the shares of walk trips in all regions, based on persontrips taken by individuals from very-low income with zero-vehicle households. Most of the increases in shares of walk trips can be attributed to the decrease in associated POV share, expect for those of the rest of NYC where no significant difference between the two NHTS years were identified. Interestingly, Figure 5-14 indicates public transit shares accounted for nearly $20 \%$ of person-trips made by individuals from the very-low income with zero-vehicle households who lived outside of NYS. This is consistent over the two NHTS years, which could indicate that 
very-low income with zero-vehicle households are more likely to live in urban areas where public transit is available.

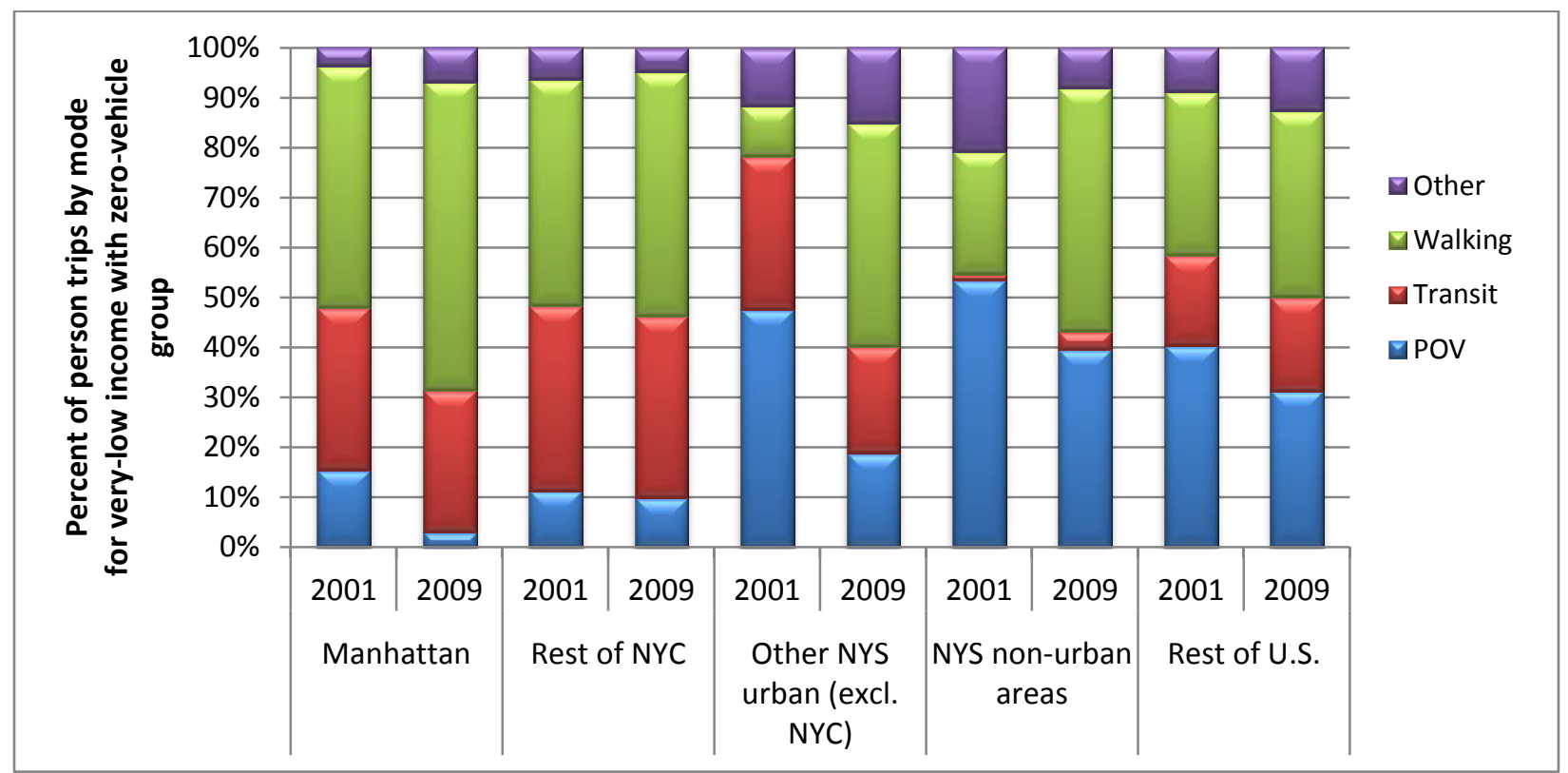

Figure 5-14. Mode shares of person-trips for very-low income with zero-vehicle households by region (2001 and 2009 NHTS)

\subsection{MOBILITY OF CHILDREN IN POVERTY}

To evaluate how income status might influence the mobility of children in NYS, this section examines travel statistics with a focus on the population ages 5 through 15 years old during 2009. Recall that, the scope of NHTS includes only persons ages 5 years and above.

\subsubsection{Person Trips}

As discussed in Section 4.2 (Figure 4-3), on average a typical very-low income New Yorker (of any age) traveled 3.1 trips daily in 2009 while a person from other income households made about 3.9 trips per day in the same year. Expectedly, NYS's children (5-15 years old) typically traveled less frequently than older NYS residents (ages of 16 years and older). On average, Figure 5-15 shows that children from a very-low-income NYS household traveled 2.7 trips daily in 2009, as compared to 3.2 trips for their counterpart older neighbors. For other income households, these daily travel frequencies are 3.2 trips and 4.1 for children and non-children of NYS residents, respectively.

Beyond the age impact on trip frequencies, the fact that individuals from a very-low income household made fewer trips than their counterpart higher income neighbors remains consistent within each age group (children or not) and for both 2001 and 2009 survey years. Income influence on travel frequencies appears to be less among children, however. Specifically, children of lower income households made about $19 \%$ (2.7 vs. 3.2) fewer trips than the higher 
income children in 2009. For those over 15 years old, this trip-frequency gap went up to about $28 \%$ (3.2 vs. 4.1$)$.

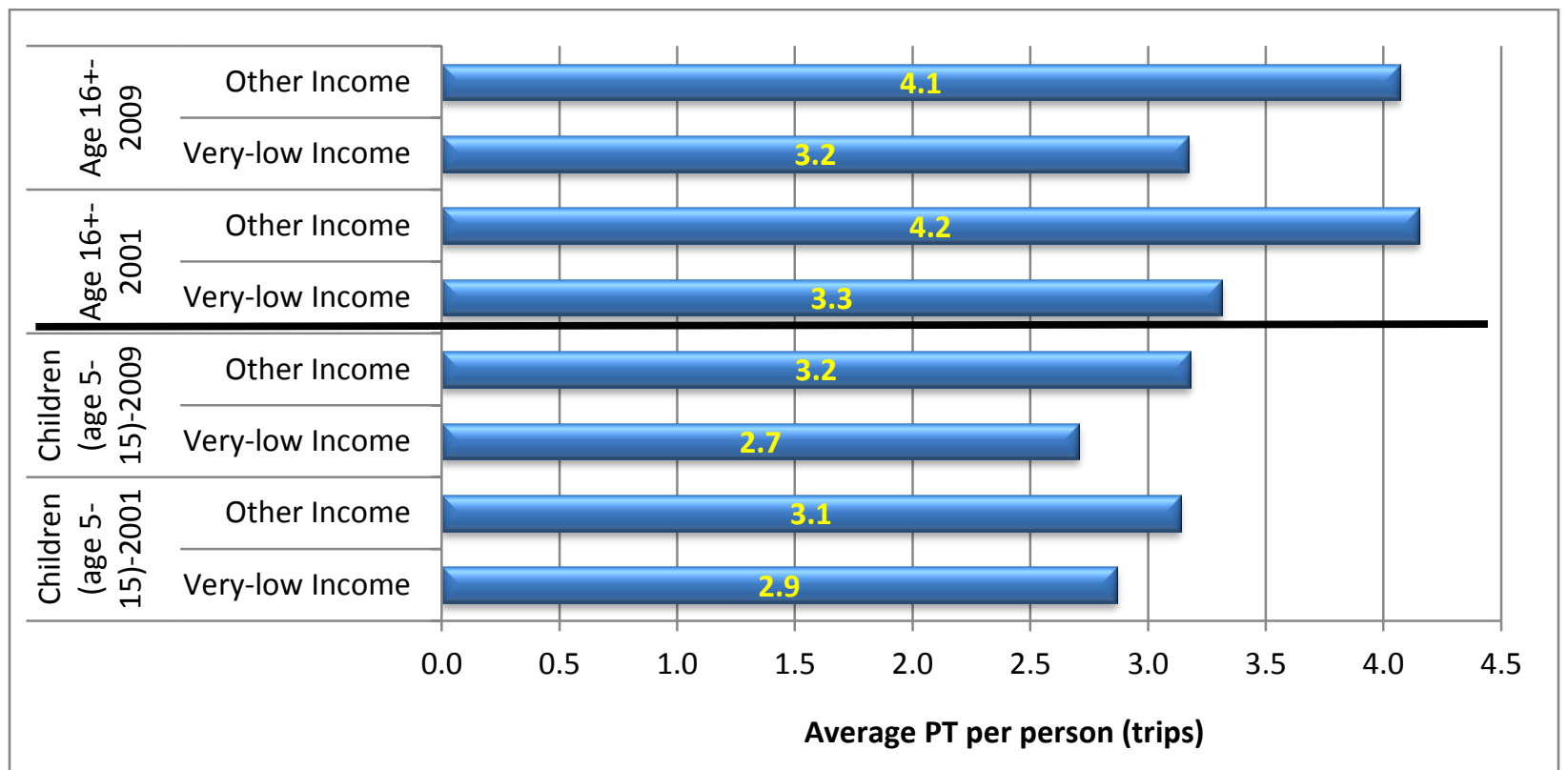

Figure 5-15. Average daily person-trips comparison between children (age 5-15 years old) and all others in NYS by income status (NHTS data)

\subsubsection{Person-Miles Traveled}

Similarly, Figure 5-16 presents average daily person-miles traveled by age group (children vs. non-children) and income status using 2001 and 2009 NHTS data. Understandably, children traveled fewer miles on a daily basis than older New Yorkers within the same income class in NYS, i.e., 9.6 miles versus 14.8 miles respectively for children of very-low income households and 21.1 miles versus 33.5 miles respectively for those from other incomes.

On any typical day, children from NYS's very-low income households traveled less than 10 miles daily on average, as compared to over 21 miles per day among children of higher income households in 2009 (Figure 5-16). The gap in average person-miles traveled between the two income groups is also significant among New Yorkers who were 16 years and older. 


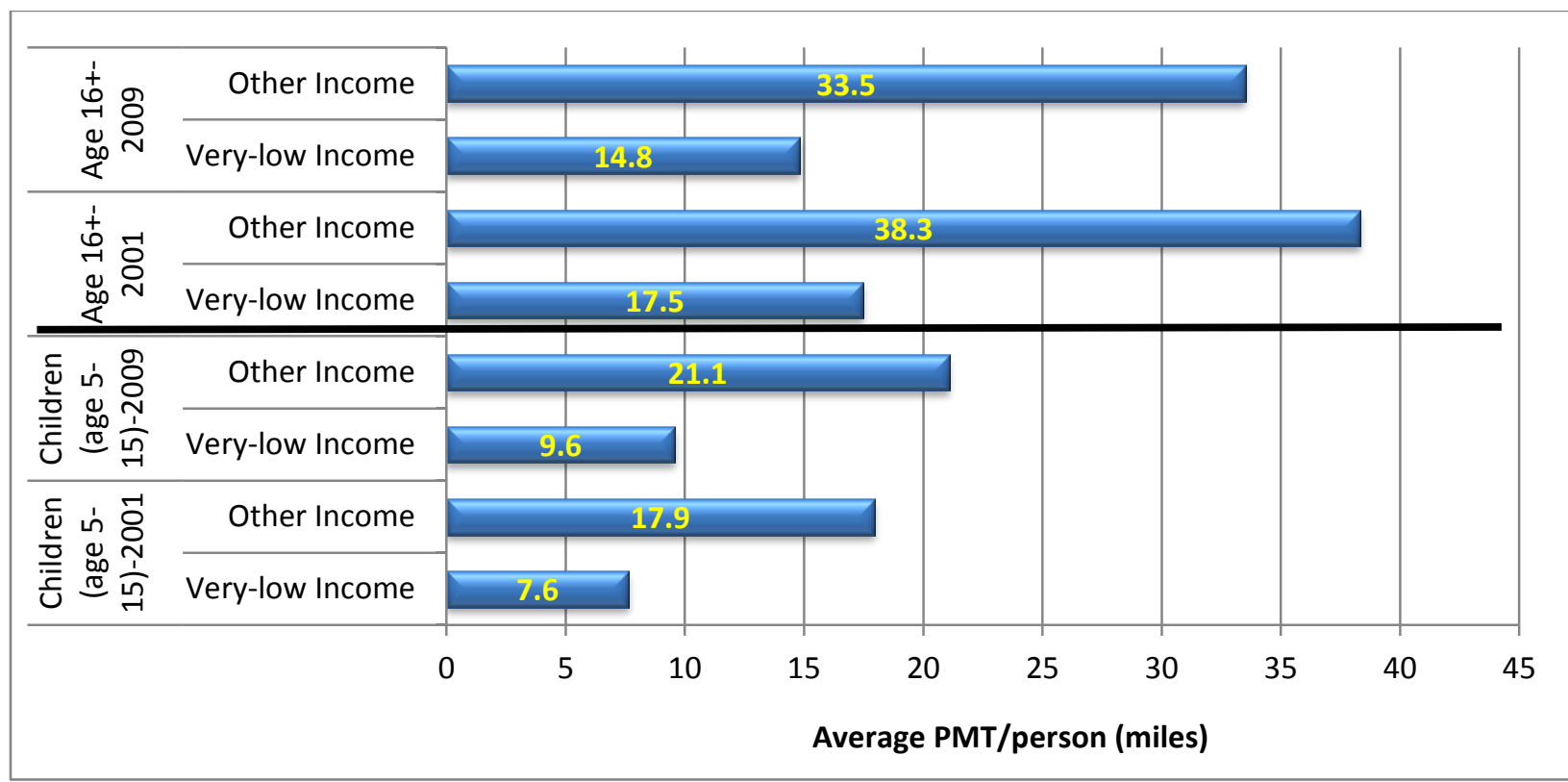

Figure 5-16. Comparison of average daily person-miles traveled between children (age 5-15 years old) and all others in NYS by income status (NHTS data)

\subsubsection{Average Person-Trip Length}

In NYS, the average person-trip length for children was shorter, by about 2 miles on average, than the age group of 16 or older, within the same income group (Figure 5-17). Moreover, verylow income individuals regardless of age typically traveled about 3 miles shorter per each trip than person trips made by their counterpart higher income neighbors in 2009.

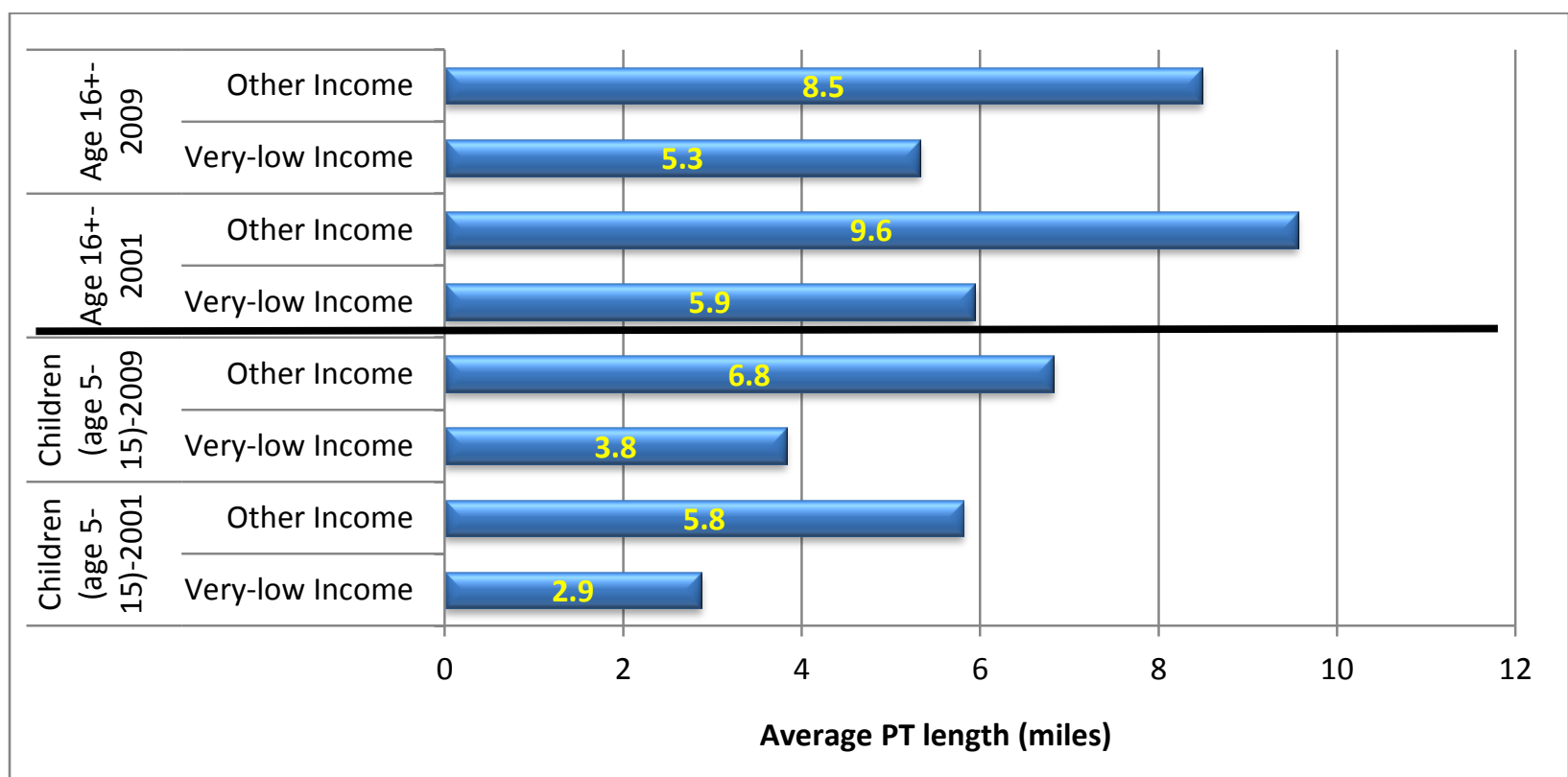

Figure 5-17. Comparison of average person-trip length between children (ages 5-15 years old) and others in NYS by income status (NHTS data) 


\subsubsection{Mode Shares on Trips Made by Children (ages 5-15 years old)}

According to 2009 NHTS data, about one-third of children in NYS lived in very-low income households, compared to $27 \%$ in the rest of the country. As presented in Table 5-3, children from very-low income households in NYS traveled the least frequency (2.7 trips on the average) and made shorter trips (average of 9.6 miles), daily, than all other children in the nation. Furthermore, children of other income households were significantly more likely to travel by POVs as compared to those of very-low income children, especially for children living in NYS. On the other hand, nearly half of the daily trips taken by a typical NYS very-low income child were made by walking or riding public transit (Table 5-3).

Table 5-3. Mobility statistics of children by mode of transportation and household income level (2009 NHTS)

\begin{tabular}{|l|c|c|c|c|}
\hline \multirow{2}{*}{ Mode Share Stats } & \multicolumn{2}{|c|}{ NYS } & \multicolumn{2}{c|}{ Rest of U.S. } \\
\cline { 2 - 5 } & $\begin{array}{c}\text { Very-low } \\
\text { Income }\end{array}$ & Other Income & $\begin{array}{c}\text { Very-low } \\
\text { Income }\end{array}$ & Other Income \\
\hline Among children under 16 & $\mathbf{3 3 . 6 \%}$ & $\mathbf{6 6 . 4 \%}$ & $\mathbf{2 7 . 3 \%}$ & $\mathbf{7 2 . 7 \%}$ \\
\hline Average PT/person & $\mathbf{2 . 7 1}$ & $\mathbf{3 . 1 8}$ & $\mathbf{2 . 8 2}$ & $\mathbf{3 . 3 4}$ \\
\hline POV & $34.0 \%$ & $58.2 \%$ & $62.2 \%$ & $74.1 \%$ \\
\hline Public transit & $17.2 \%$ & $5.3 \%$ & $2.0 \%$ & $0.3 \%$ \\
\hline Walk & $32.2 \%$ & $17.8 \%$ & $19.0 \%$ & $10.9 \%$ \\
\hline Other & $16.7 \%$ & $18.6 \%$ & $16.6 \%$ & $14.6 \%$ \\
\hline Unreported & & & $0.3 \%$ & $0.1 \%$ \\
\hline All & $100 \%$ & $100 \%$ & $100 \%$ & $100 \%$ \\
\hline Average PMT/person & $\mathbf{9 . 5 7}$ & $\mathbf{2 1 . 0 7}$ & $\mathbf{1 5 . 7 9}$ & $\mathbf{2 9 . 3 9}$ \\
\hline POV & $65.5 \%$ & $67.9 \%$ & $84.8 \%$ & $81.5 \%$ \\
\hline Public transit & $14.6 \%$ & $2.8 \%$ & $1.6 \%$ & $0.1 \%$ \\
\hline Walk & $4.4 \%$ & $1.5 \%$ & $2.1 \%$ & $0.7 \%$ \\
\hline Other & $15.5 \%$ & $27.8 \%$ & $11.3 \%$ & $17.6 \%$ \\
\hline Unreported & & & $0.2 \%$ & $0.1 \%$ \\
\hline All & $100 \%$ & $100 \%$ & $100 \%$ & $100 \%$ \\
\hline Average PT Length & $\mathbf{3 . 8}$ & $\mathbf{6 . 8 2}$ & $\mathbf{5 . 9 7}$ & $\mathbf{8 . 9 3}$ \\
\hline
\end{tabular}

Furthermore, as shown in Table 5-3, around two-thirds of the daily person-miles traveled by children from NYS were by POVs, regardless of their household income levels. Expectedly, the POV shares of person-miles traveled for children residing outside of NYS were significantly higher, at $85 \%$ and $82 \%$ for children from very-low income and other income groups, respectively. The very-low income children in NYS traveled an average of 3.8 miles per trip as compared to 6.8 miles per trip for their other income counterpart neighbors-equivalent to an approximately $80 \%$ longer distance per trip. Outside of NYS, children from other income households made about 50\% longer trips than those from very-low income households, 8.9 miles versus 6.0 miles, respectively.

\subsection{VERY-LOW-INCOME ELDERLY}

As summarized in Table 5-4, a significant portion of very-low income elderly households (i.e., a household with one or more persons of ages $65+$ years) were single-person households, 
regardless of where they lived in 2009. Specifically, nearly three in five (59\%) very-low income elderly households in NYS, but outside of NYC, lived alone, while it was $46 \%$ for those residing inside of NYC. The share of single occupant very-low income elderly households in the rest of U.S. is also significant and accounted for $53 \%$ of all very-low income elderly households in this region during 2009.

Table 5-4. Very-low income elderly households by household size and region in 2009 (NHTS data)

\begin{tabular}{|l|c|c|c|c|c|c|}
\hline \multirow{2}{*}{$\begin{array}{c}\text { Very-low income } \\
\text { elderly households } \\
\text { (HHs) }\end{array}$} & \multicolumn{3}{|c|}{ Number of households } & \multicolumn{3}{c|}{ Number of persons } \\
\cline { 2 - 7 } & $\begin{array}{c}\text { 1-person } \\
\text { HHs }\end{array}$ & $\begin{array}{c}\text { 2+ persons } \\
\text { HHs }\end{array}$ & $\begin{array}{c}\text { \% live } \\
\text { alone }\end{array}$ & $\begin{array}{c}\text { 1-person } \\
\text { HHs }\end{array}$ & $\begin{array}{c}\text { 2+ persons } \\
\text { HHs }\end{array}$ & $\begin{array}{c}\text { \% live } \\
\text { alone }\end{array}$ \\
\hline New York City & 192,407 & 223,881 & $46.2 \%$ & 203,070 & 692,996 & $22.7 \%$ \\
\hline Rest of NYS & 276,866 & 192,622 & $59.0 \%$ & 256,766 & 528,264 & $32.7 \%$ \\
\hline Rest of U.S. & $6,398,797$ & $5,624,308$ & $53.2 \%$ & $5,580,859$ & $4,135,572$ & $28.3 \%$ \\
\hline
\end{tabular}

As shown in Figure 5-18, more than half of person-trips made by a very-low income elderly household in 2009 were to conduct family/personal business activities, irrespective of where they lived. Besides that, nearly all of the remaining person-trips taken by very-low income elderly households were made for social or recreational purposes. Clearly visible in Figure 5-18 was a significantly higher share of person-trips made for earning a living among $2+$ occupants in the very-low income elderly households. That is, it is more likely for households with two or more members to have a worker (i.e., making work trips) than those who lived alone. Overall, no significant regional differences for the shares by trip purpose are observed in Figure 5-18.

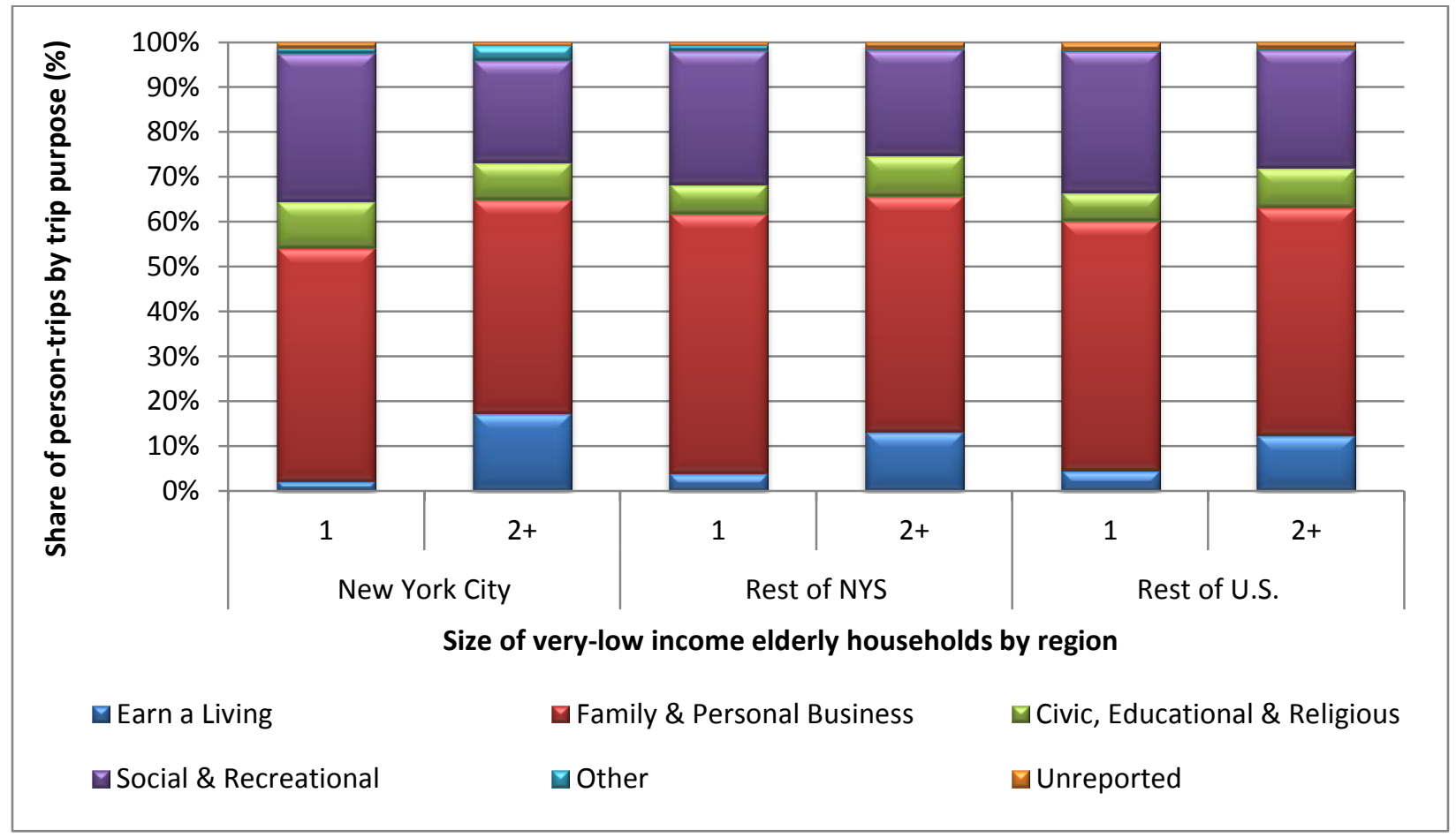

Figure 5-18. Shares of person-trips for very-low income elderly households by trip purpose, household size, and region of residency in 2009 
In terms of mode share, individuals from a very-low income elderly household in NYC have a significantly higher likelihood of walking or taking public transit for their trips, as compared to trips made by their counterparts from other regions. Based on information illustrated in Figure 5-19, about half of the person-trips made by a single occupant very-low income elderly household in NYC were walking and another $24 \%$ of their trips were taken on public transit. On the other hand, Figure 5-19 shows that trips made by persons from a multi-occupant very-low income elderly household in NYC were split almost equally among modes of POV, public transit, and walking. Expectedly, POV was the main mode of transportation (either as a driver or a passenger) for persons from very-low income elderly households located outside of NYC, and accounted for about $80 \%$ of their daily person-trips taken in 2009 (Figure 5-19).

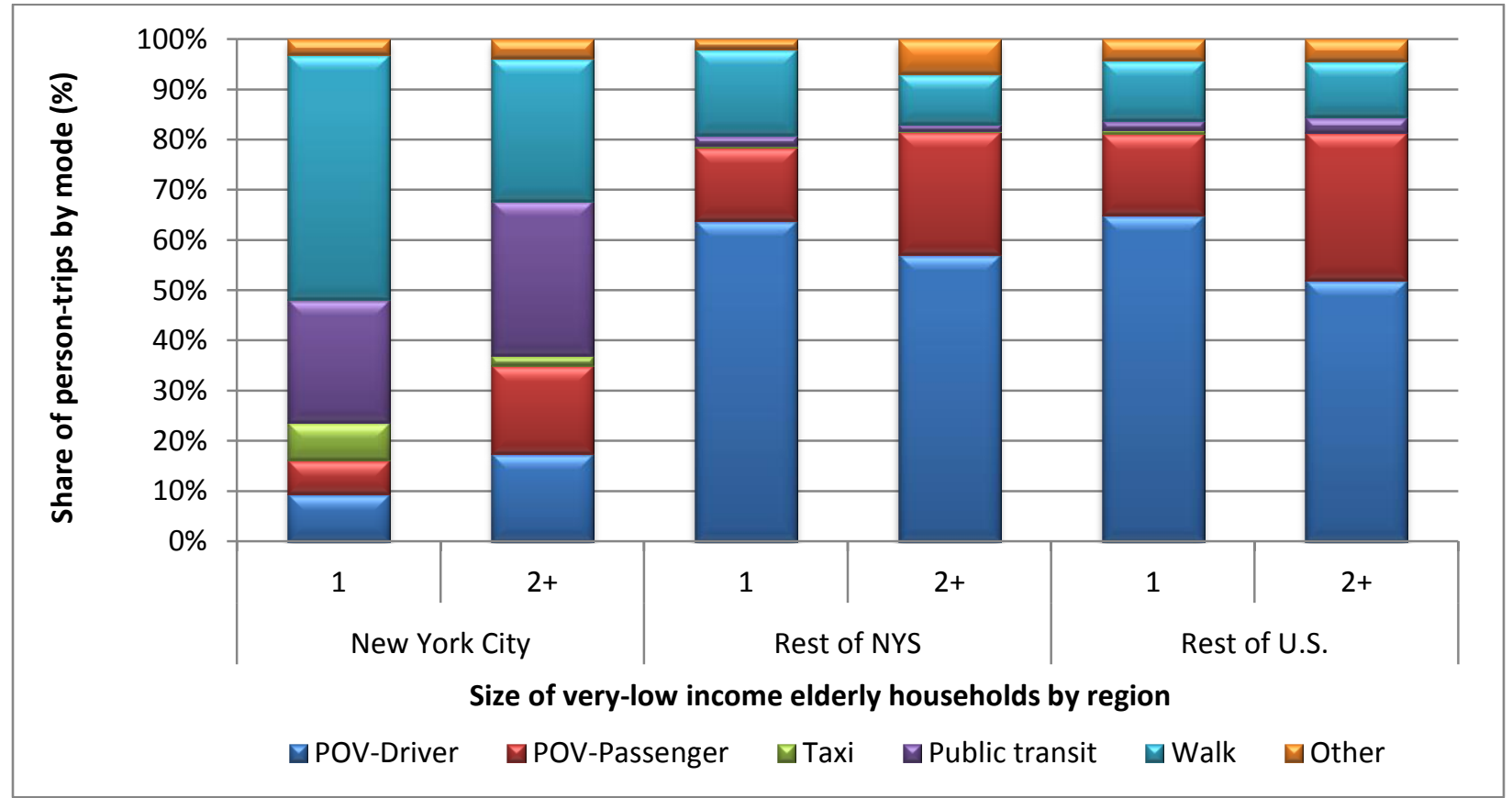

Figure 5-19. Mode share on person-trips made by individuals from very-low income elderly households, by household size and region (2009 NHTS)

Figure 5-20 summarizes mobility statistics (measured in person-trips) for very-low income elderly households by size and location of the household. Although no significant differences were found in terms of travel frequencies (i.e., PT/person), single individuals from a very-low income elderly household in NYC traveled shorter distances on a daily or per-trip basis, as compared to trips made by their larger household counterpart neighbors. Due to sample size limitations, nearly all estimates presented in the lower part of Figure 5-20 were associated with relatively high uncertainties. The only statistically significant differences can be drawn with average PMT and average PT length were between the single and 2+ groups, specifically among very-low income elderly households who lived in the rest of the U.S.

For POV trips, Figure 5-21 shows that NYC drivers from very-low income elderly households clearly made significantly fewer vehicle trips than their counterparts that lived 
outside of NYC, regardless of household size. Similar to above, the impact of household-size was only significant (statistically) on average vehicle-trip distances (VMT/driver and VT length per driver), where single household drivers from a very-low income elderly household from the rest of the U.S. traveled shorter distances than vehicle-trips made by their counterpart drivers from multiple-person households in the same region.

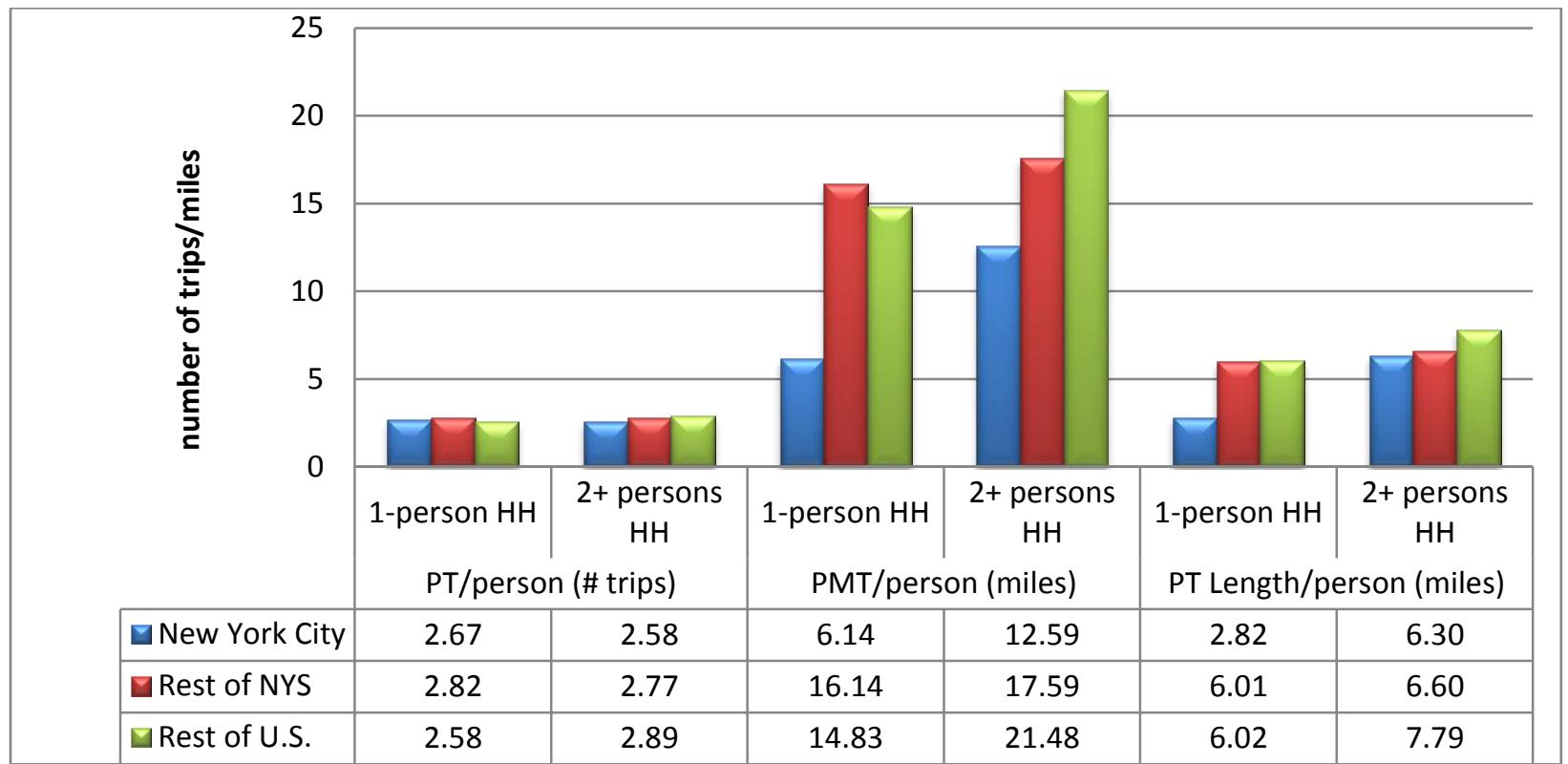

Figure 5-20. Travel statistics for trips made by persons from very-low income elderly households by size of household and region (2009 NHTS)

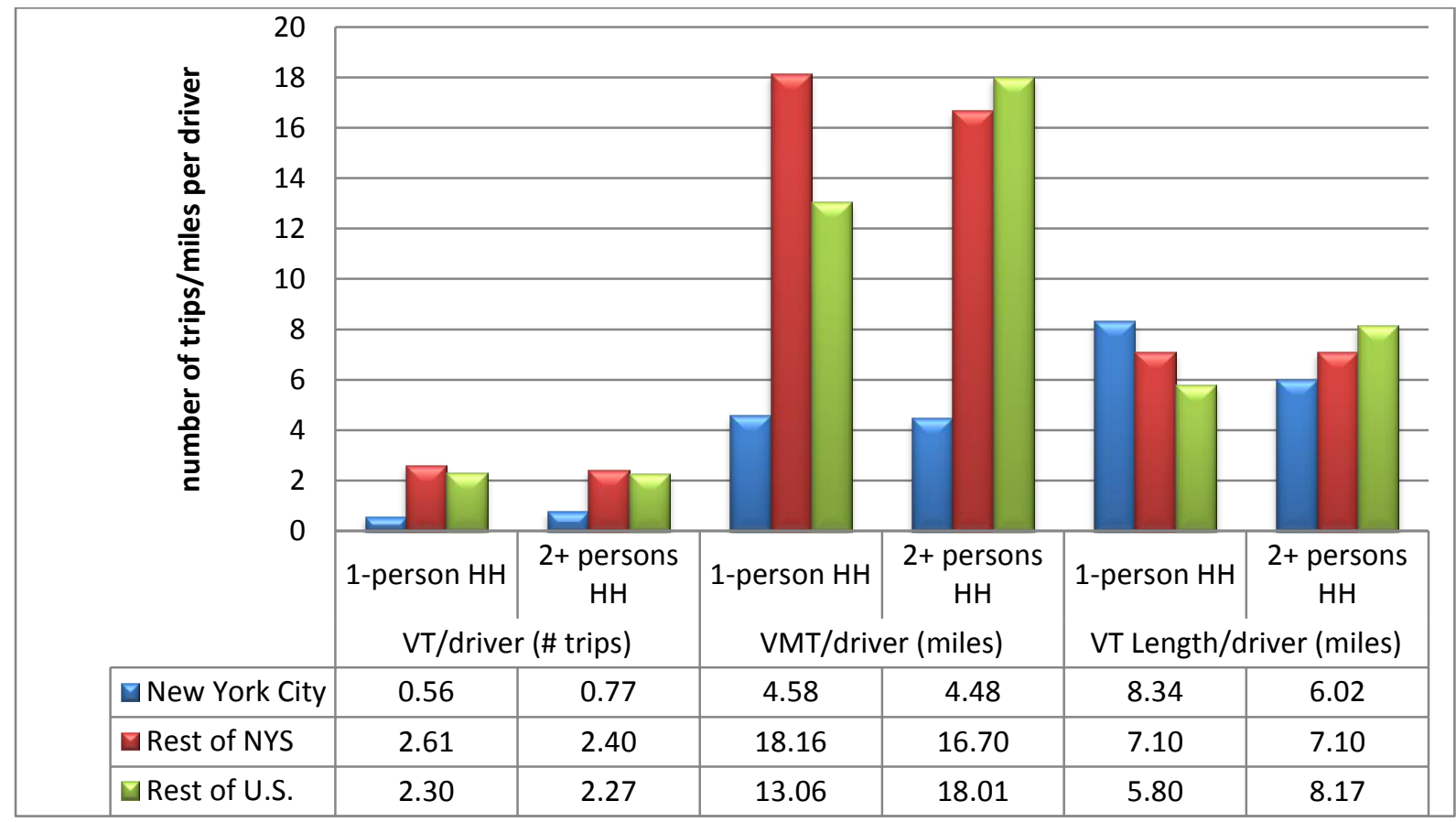

Figure 5-21. Travel statistics for vehicle trips made by drivers from very-low income elderly households, by size and region (2009 NHTS) 



\section{VIEWS OF TRANSPORTATION SERVICES BY LOW-INCOME HOUSEHOLDS}

Under the 2009 NHTS, each survey respondent was asked to select one concern (out of the list below) that the respondent considered as the most important issue related to his/her travel. The choices were:

- Highway congestion

- Access to or availability of public transit

- Lack of walkways or sidewalks

- Price of travel including things like transit fees, tolls, and the cost of gasoline

- Aggressive or distracted drivers

- Safety concerns, like worrying about being in a traffic accident

After one item was selected as the most important issue, a follow-up question was then asked - which required the respondent to rate the selected issue/concern as: a little issue, a moderate issue, or a big issue. Information collected from these two survey questions are the basis for statistical summaries reported in this Section.

\subsection{PERCEPTIONS ON BIG ISSUES}

According to the 2009 NHTS, Figure 6-1 shows that "access or availability of public transit" was viewed as a big concern by $66 \%$ of NYS's other income residents who considered it as the most important issue. Over half (57\%) of other income NYS residents identified "price of travel" as their most important issue and it was considered a big concern.

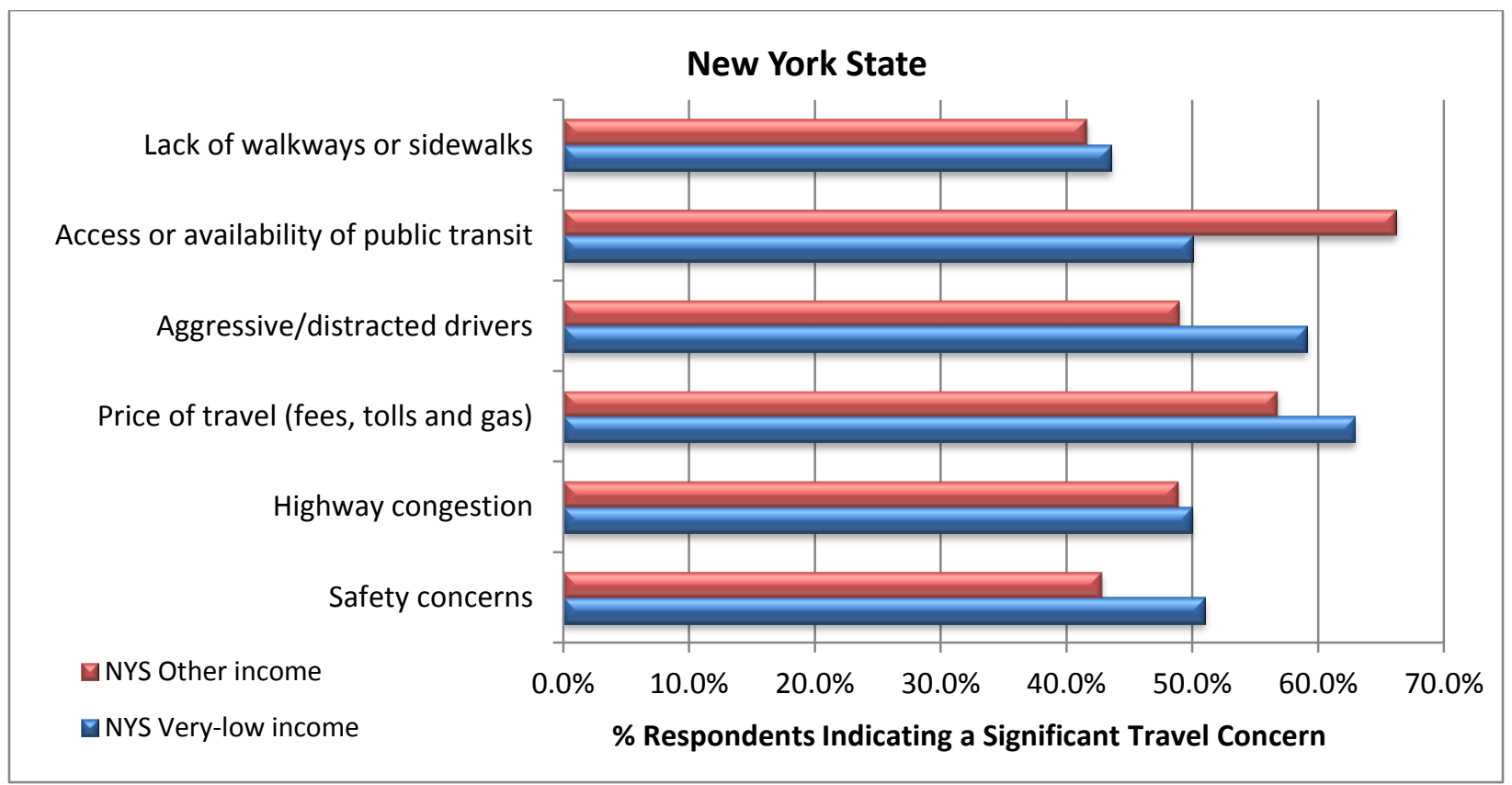

Figure 6-1. Big issues associated with travel concerns by NYS residents (2009 NHTS) 
Among NYS's very-low income individuals, 63\% indicated "price of travel" as the most important issue and thought that was a big problem. The issue of "aggressive/distracted drivers" was expressed as a big issue for 59\% of the very-low income New Yorkers who selected this item as their most important concern. Interestingly, "access/availability of public transit" was only considered "a big issue" by half of those very-low income NYS residents who identified it as their most important issue.

Outside of NYS, "price of travel" was reflected as a big issue by $59 \%$ and $65 \%$ of those who identified it as their most important concern among individuals from the other income households and the very-low income households, respectively (Figure 6-2). No significant differences were visible concerning respondents" attitudes toward the "lack of walkways or sidewalks" or "highway congestion" between individuals from the two income groups, regardless of where they lived.

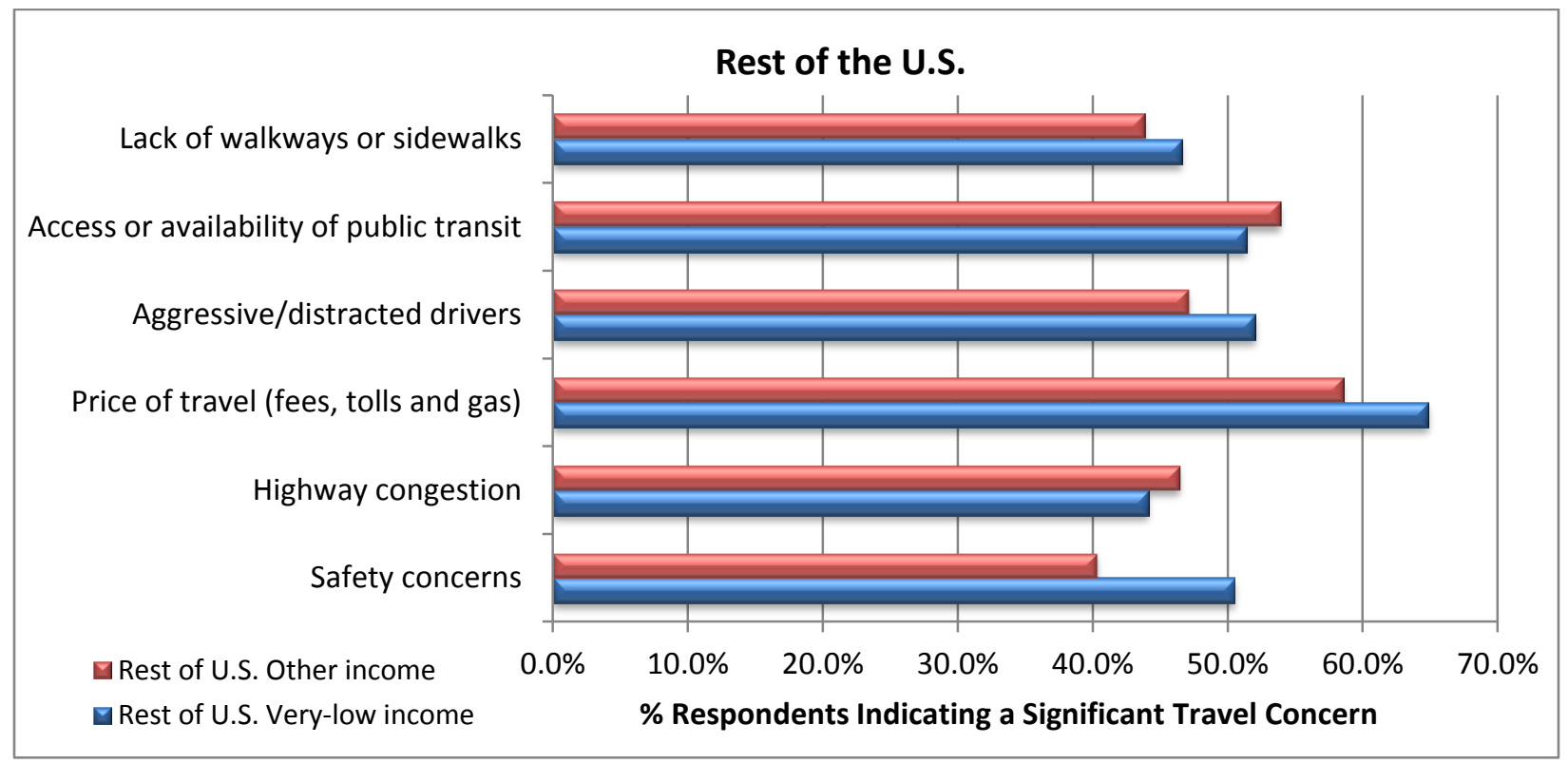

Figure 6-2. Big issues of travel concerns for individuals lived in the Rest of U.S. (2009 NHTS)

\subsection{OPINIONS ON LITTLE ISSUES}

On the other hand, although "Access/availability of public transit" was selected as the most important concern by certain New Yorkers, some actually noted that it was only a little issue (i.e., trivial) during the follow-up question. Specifically, nearly $20 \%$ of very-low income NYS individuals, who expressed "Access/availability of public transit" as the most important concern, said it was a little issue; compared to $14 \%$ among the higher income respondents from NYS (Figure 6-3). A similar pattern was also found for individuals living in the rest of the U.S. (Figure 6-4). 


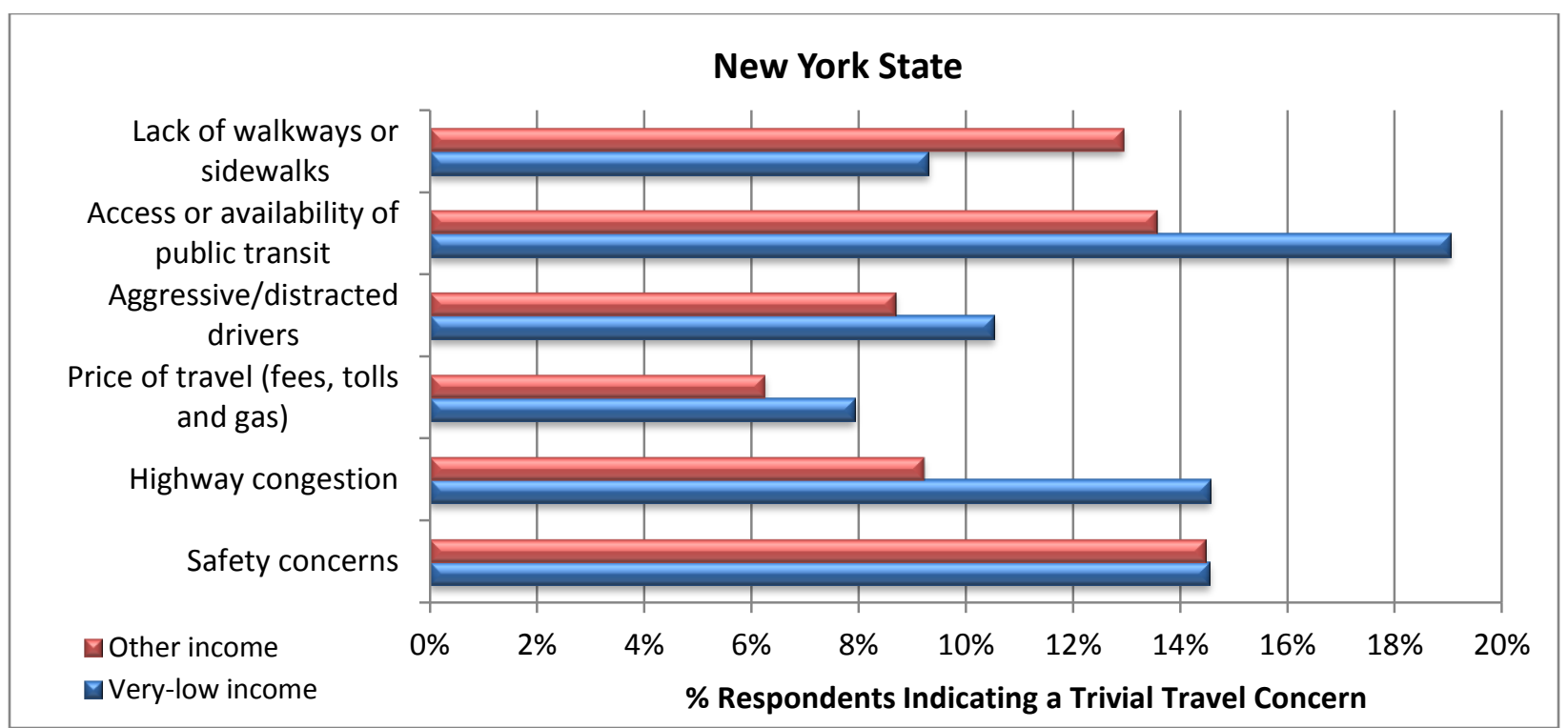

Figure 6-3. Travel concerns identified as big issues by individuals living in NYS (2009 NHTS)

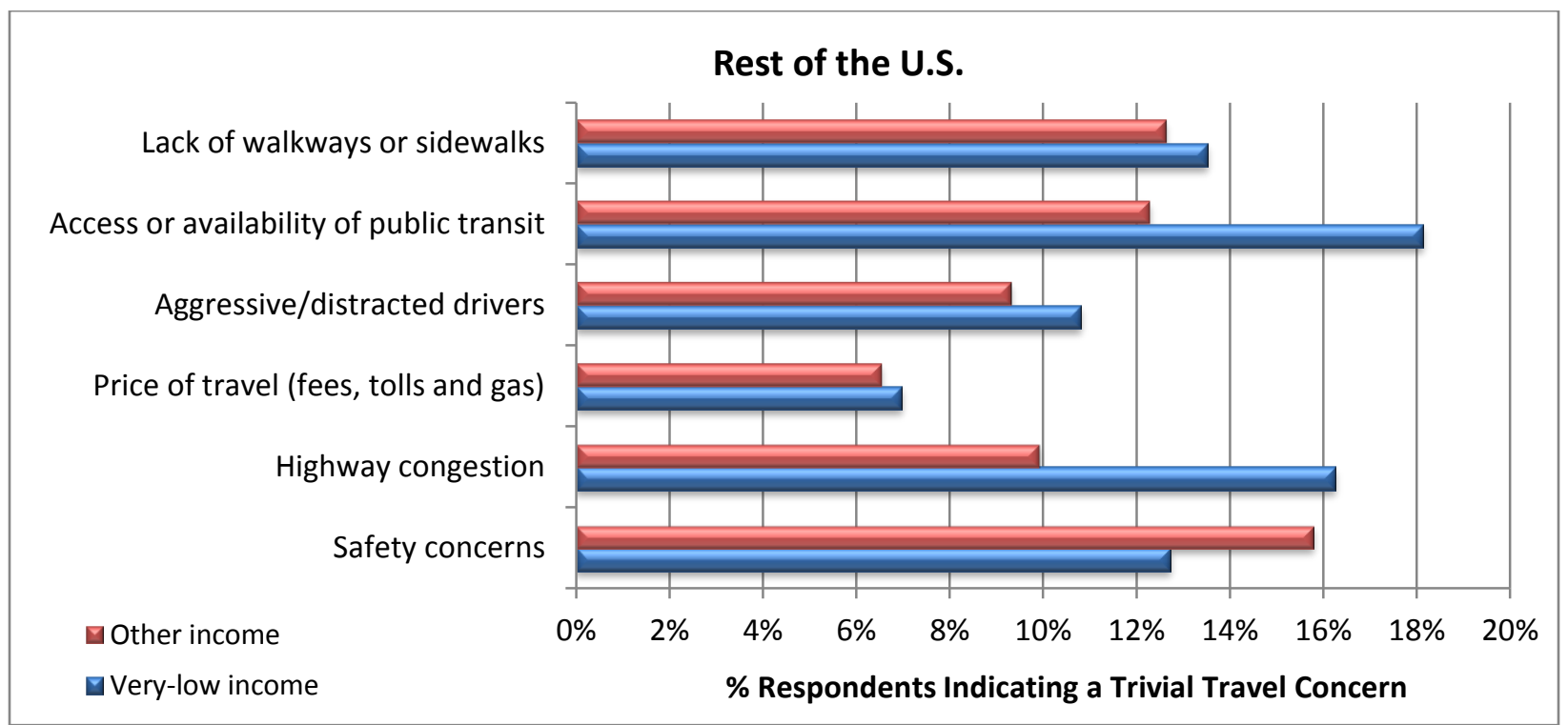

Figure 6-4. Travel concerns identified as little issues by individuals living in the Rest of U.S. (2009 NHTS)

\subsection{COST OF TRAVEL}

Among New Yorkers who identified the "price of travel" as their most important travel concern in 2009, $63 \%$ of those came from a very-low income household responded this was a big issue (Figure 6-5), compared to 57\% of higher income households. Outside of NYS, the percentage of individuals who expressed the "price of travel" as the most important concern, and a big issue, were slightly higher than NYS, 65\% among very-low income respondents and 59\% in the higher income respondents. As shown in Figure 6-5, a small percent of those who expressed the "price of travel" as their most important concern said it was a little issue, regardless of income. 


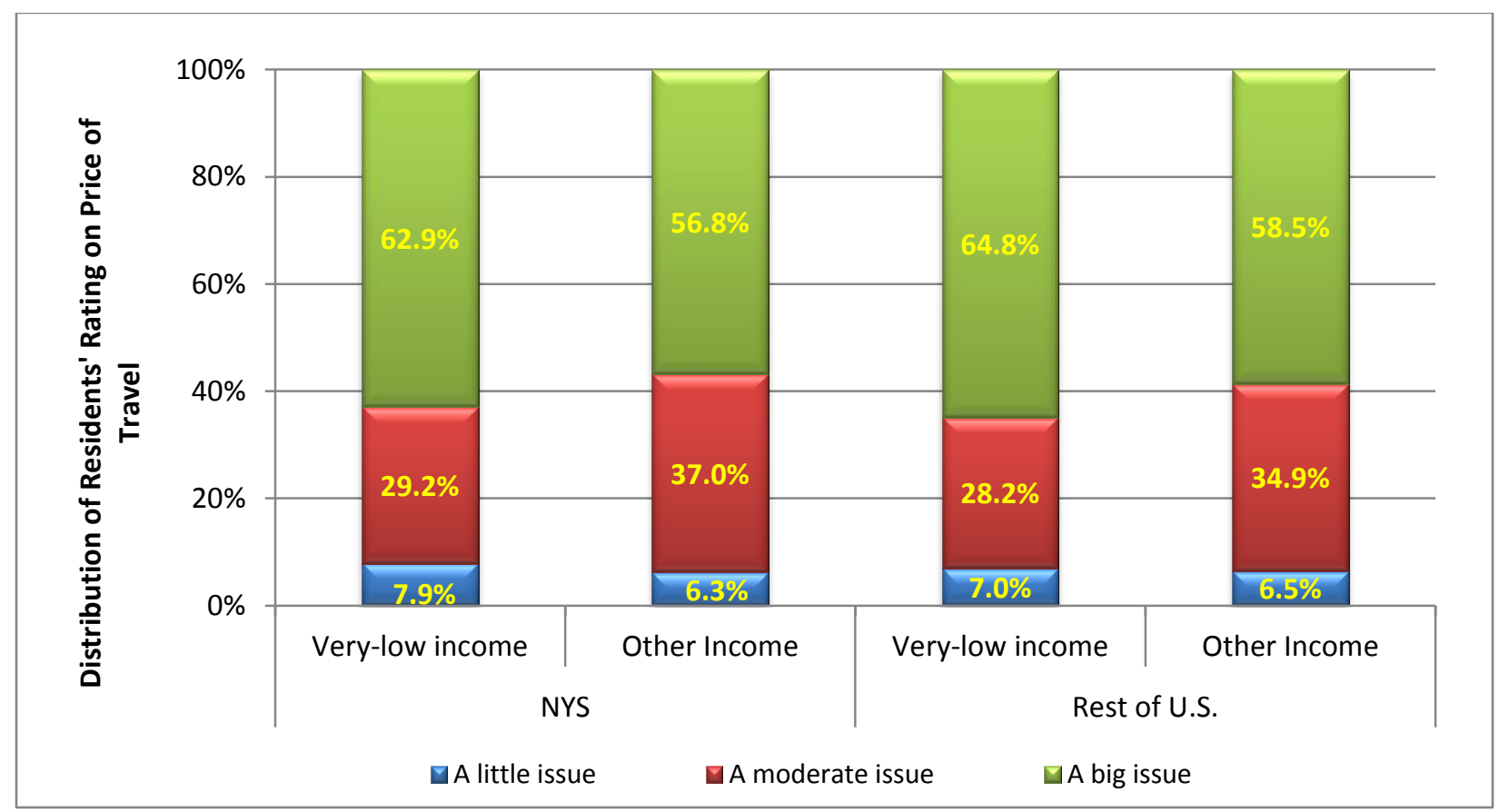

Figure 6-5. Share of rating on residents' view among those who expressed "price of travel" was the most important concern by income status and region (2009 NHTS)

Furthermore, across NYS regions, more than half of all those who identified the "price of travel" as their most important travel concern have expressed that it was a big issue (Figure 6-6). This view was shared by very-low income individuals as well as those with higher incomes. In all regions, except for residents of Manhattan, individuals from a very-low income household were more likely to choose price of travel as a big issue than those of their counterpart higher income neighbors.

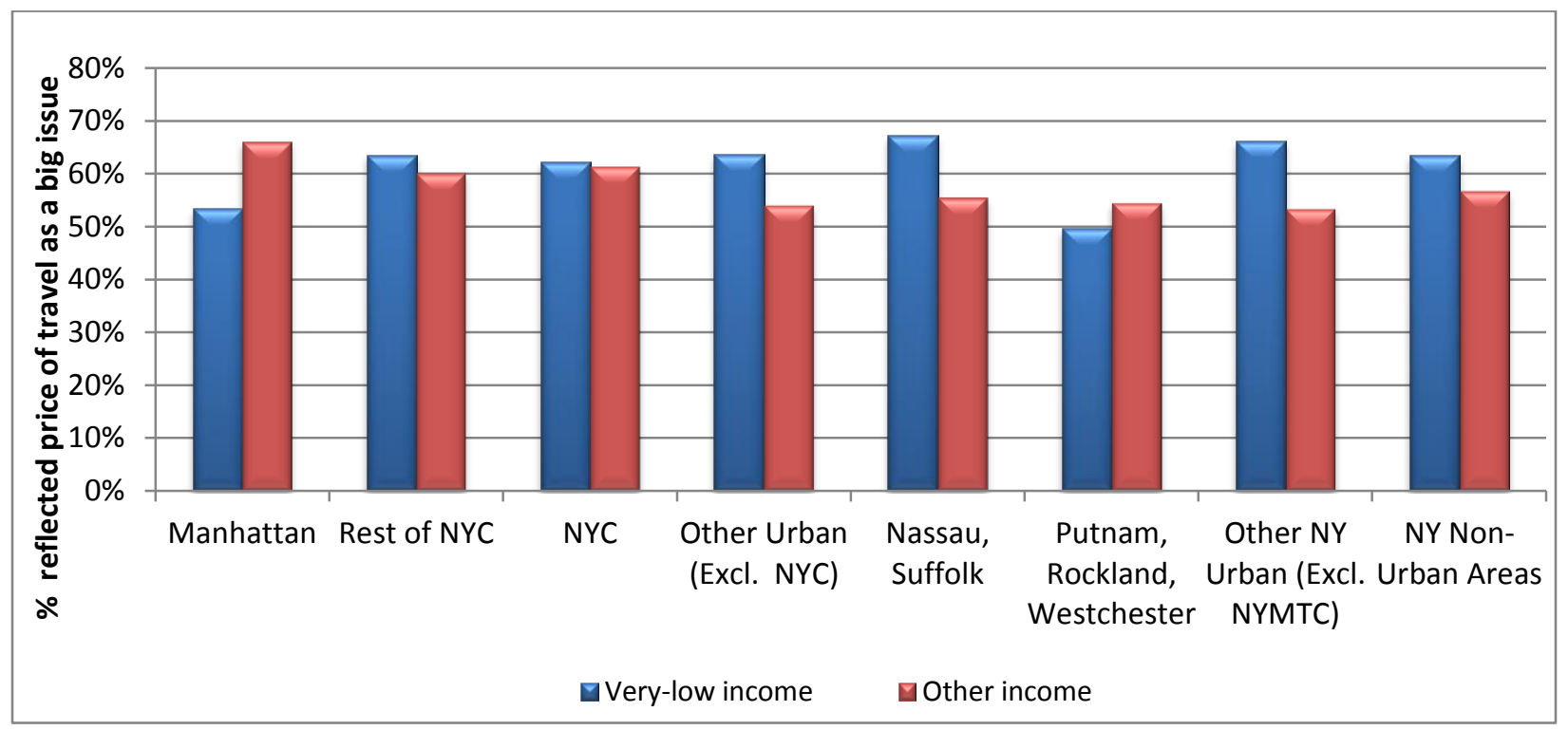

Figure 6-6. Percent of individuals who thought price of travel was a big issue given that it was the most important issue they identified, by income and region (2009 NHTS) 


\subsection{COMPARISON WITH VIEWS FROM VERY-LOW INCOMES}

Because questions used in the 2009 NHTS for gathering respondents' view of transportation services are different from those included in previous surveys (where all questions were asked of all respondents, not just those indicating an issue as most important), only some general comparisons between a few issues can be compiled. Considering only responses from the verylow income individuals, Figure 6-7 shows that the percentage of significant concerns (or big issues) regarding the "lack of walkways/sidewalks," "highway congestion," and "worrying about a traffic accident" were all much higher in 2009 than previous years. Regional differences between very-low income New Yorkers and residents from the rest of the U.S. were not significant. Note that 2009 NHTS questions did not include concerns for "rough pavement or potholes" or "traffic or road congestion."

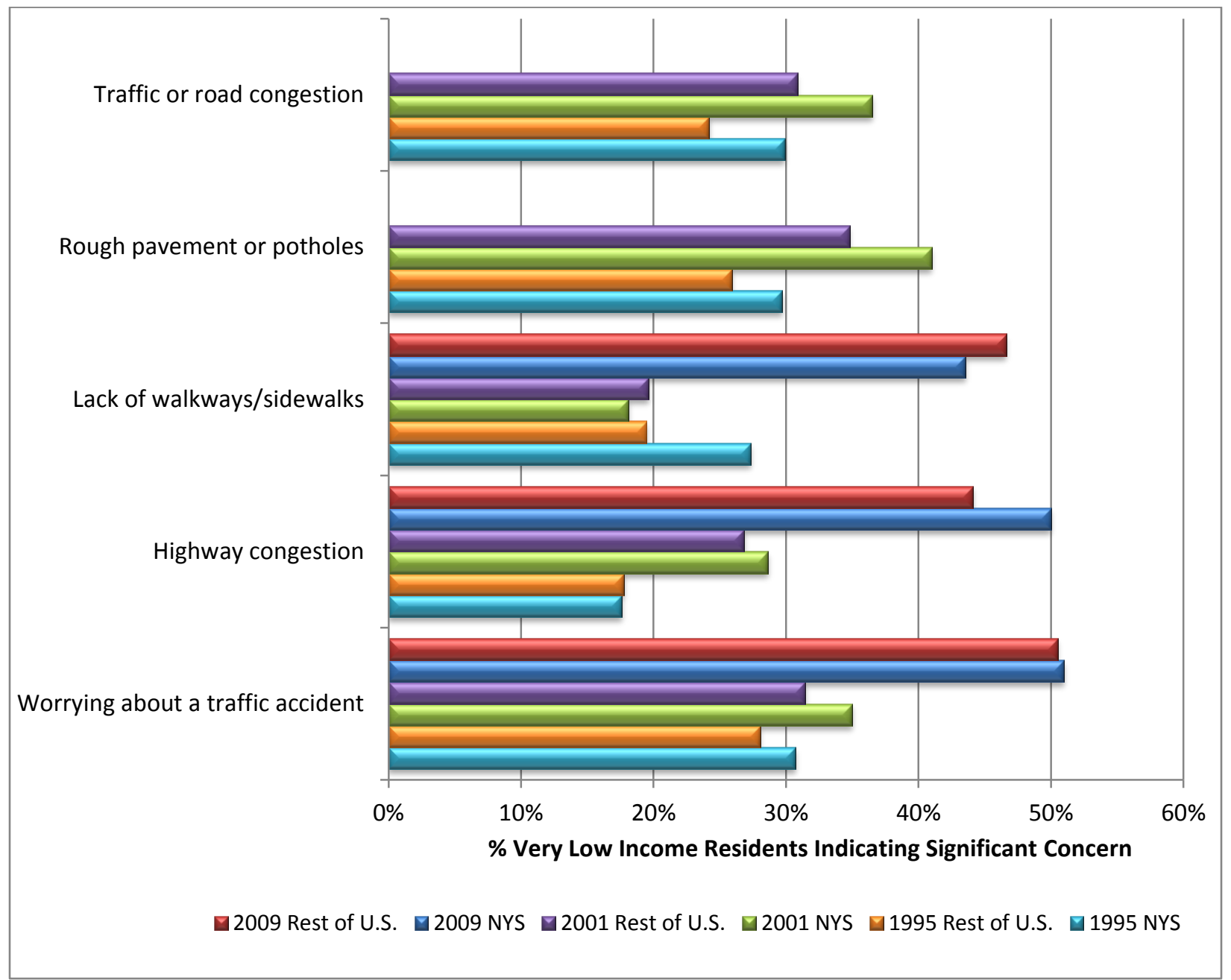

Figure 6-7. Percent of very-low income residents indicating a given issue as significant concern or a big issue 


\section{SUMMARY}

\subsection{OVERVIEW}

This report details finding from an examination of travel behaviors and patterns (or trends) associated with the low-income population in NYS. The main data source used in this study was the 2009 NHTS (including national and add-on samples in NYS). Due to the uniqueness of NYC, regional analyses were conducted by comparing statistics from NYC to other regions in NYS in many cases.

As described in Section 2.5 of this report, the "low-income" term in this study was based on HUD's definition of very-low income households. That is, the low-income cutoffs were adjusted for both household size and geographic region so that they can better account for differences in regional housing markets, which is particularly important in areas such as NYC. Two groups of income categories were used in this study, namely very-low income and other income.

\subsection{KEY FINDINGS}

\subsubsection{Population Size}

* Based on the 2009 NHTS, 29\% of NYS residents (ages 5 years and older) lived in verylow income households, and accounted for $32 \%$ of the total households in NYS (Figure 3-1 and Figure 3-2).

* In 2009, the greatest concentration of very-low income NYS residents was in NYC but located outside of Manhattan. One in four persons who lived in Manhattan came from a very-low income household, as compared to $44 \%$ for those who lived elsewhere in NYC ( 
* Table 3-1).

* Similarly, the share of very-low income residents within NYS (as a whole) was $31 \%$, versus $26 \%$ in the rest of the U.S. ( 
Table 3-1).

\subsubsection{Characteristics of the Low-Income Households}

* Poverty rates among African-American and Hispanic populations are significantly higher than other races among NYS residents. The share of very-low income Hispanic populations in NYS went from $44 \%$ in 1995 to $63 \%$ in 2009, while the rate among African-Americans remained under 50\% and their counterpart White neighbors stayed under 20\% (Figure 3-4 and Figure 3-5).

* Nearly two in five very-low income NYS households were single occupant (i.e., lived alone) in 2009, while it was less than one in four among NYS's higher income households in the same year. The majority of the very-low income residents who lived alone in NYS were retired adults (Figure 3-10 and Table 3-2).

* According to the 2009 NHTS, 22\% of very-low income households in NYS had no access to drivers in their households (i.e., no drivers) as compared to only $3 \%$ among their higher income neighbors (Figure 3-7).

* Half of all very-low income households in NYS owned zero vehicles in 2009, compared to only $16 \%$ of their higher income neighbors with zero-vehicles in the household. Verylow income households located outside of NYS also had a higher likelihood of owning zero vehicles than their higher income neighbors, with $20 \%$ versus $2 \%$ respectively. The likelihood of being a zero-vehicle household in NYC is significantly higher than areas outside of NYC, regardless of income level (Figure 3-11, Figure 3-12, and Figure 3-13).

* During 2009, nearly three-quarters of NYS's very-low income households with zerovehicles were located in NYC (Figure 3-18). Outside Manhattan, zero-vehicle households are predominately very-low income households (Figure 3-20).

* On average, vehicles owned by a very-low income household in NYS were about 2 years older than vehicles owned by their higher income neighbors (Figure 3-15).

* While less than $37 \%$ of very-low income populations from the rest of NYC (i.e., lived outside Manhattan) were workers in 2009, nearly $60 \%$ of their higher-income neighbors were employed during the same year (Figure 3-16).

\subsubsection{Travel Patterns of Very-Low Income Population}

During 2009, $17 \%$ of NYS residents from a very-low income household did not travel, while only $12 \%$ of their counterpart higher income neighbors did not travel. This similar pattern was consistent over time since 1995 (Table 4-1).

* Although the very-low income population merely accounted for $31 \%$ of NYS residents (ages five years and older) in 2009, nearly $40 \%$ of New Yorkers who did not travel on their NHTS-assigned travel day were from very-low income households (Figure 4-1). 
* For vehicle travel, $57 \%$ of NYS drivers who lived in a very-low income household did not drive on their travel day in 2009, as compared to $37 \%$ of NYS drivers from higher income households (Table 4-2).

* The NHTS data shows that mobility for individuals from a very-low income household was more limited than that of other income individuals - regardless of how mobility was measured (based on drivers only or considered all NYS residents).

* New Yorkers who lived in very-low income households were more likely to travel for family/personal business or school/church activities, but less likely to travel for work or social/recreational purposes as compared to their higher income neighbors (Figure 4-4).

* Higher income New Yorkers predominantly traveled by POVs (either as a driver or as a passenger) regardless of trip purposes. A POV was also the most used mode for individuals from a very-low income NYS household when making trips for work or for visiting family and conducting personal business. For other trips, very-low-income New Yorkers were most likely to use public transit or walk to reach their destinations (Table 4-3).

* Considering why walking was used when making a daily trip, a very-low income New Yorker had a higher likelihood of traveling by walking to conduct their non-work associated daily activities than their higher income neighbors (Figure 4-10).

\subsubsection{Mobility of Very-Low Income Population}

- On average, persons from a very-low income household traveled less frequently than their higher-income counterpart neighbors did in the same year.

* While a NYS resident in other income group traveled an average of 3.95 trips daily during 2009, a very-low income individual from NYS took nearly $22 \%$ fewer trips on a daily basis in the same year (Figure 4-3 and Table 7-1).

Table 7-1. Mobility statistics for person-trips taken by NYS residents by income status

\begin{tabular}{|l|r|r|r|}
\hline Travel Statistics - person trips & \multicolumn{1}{|l|}{$\mathbf{2 0 0 9}$} & $\mathbf{1 9 9 5}$ \\
\hline Avg. PT/person & 3.10 & 3.23 & 3.43 \\
\hline Very-low income & 3.95 & 3.98 & 4.16 \\
\hline Other income & $-21.5 \%$ & $-18.8 \%$ & $-17.5 \%$ \\
\hline \% difference between income groups & 13.97 & 15.87 & 18.22 \\
\hline Average PMT/person & 31.77 & 34.98 & 33.61 \\
\hline Very-low income & $-56.0 \%$ & $-54.6 \%$ & $-45.8 \%$ \\
\hline Other income & 5.11 & 5.49 & 5.67 \\
\hline \% difference between income groups & 8.30 & 9.08 & 8.29 \\
\hline Average Person trip length & $-38.5 \%$ & $-39.5 \%$ & $-31.6 \%$ \\
\hline Very-low income &
\end{tabular}


* About $70 \%$ of daily person-trips taken by a typical other income New Yorker were made in a POV (either as a driver or as a passenger), as compared to only $47 \%$ for trips made by a very-low income New Yorker in 2009 (Figure 4-5).

* NYS's very-low income residents were more than twice as likely to use public transit for their daily travel. Mode share for person-trips made by walking was also significantly higher among very-low income New Yorkers (Figure 4-5).

* Based on NHTS data, a very-low income NYS resident traveled $56 \%$ fewer miles as compared to trips taken by a New Yorker in other income group. In 2009, a very-low income New Yorker traveled an average of 14 miles per day, versus 32 miles per day among the other New Yorkers (Figure 4-12 and Table 7-1).

* A typical very-low income New Yorker traveled significantly fewer miles (measured in PMT) than one from a higher income household, particularly on trips made for work, family/personal business, and social/recreational purposes (Figure 4-13).

* Statewide, very-low income New Yorkers traveled on average about 5.1 miles per trip, while their other income neighbors took $62 \%$ longer trips, over 8.3 miles per trip in 2009 (Figure 4-14).

* As illustrated in Figure 7-1, for every trip (measured in PT) made by a New Yorker in other income category in 2009, a very-low income NYS resident only took 0.8 trips. Moreover, for every person-mile (measured in PMT) a higher income NYS resident traveled, the very-low income person only made about 0.44 person-miles in the same year. With respect to the average daily person-trip length in 2009, a very-low income individual from NYS traveled only 0.6 miles for every mile that a New Yorker in other income group made.

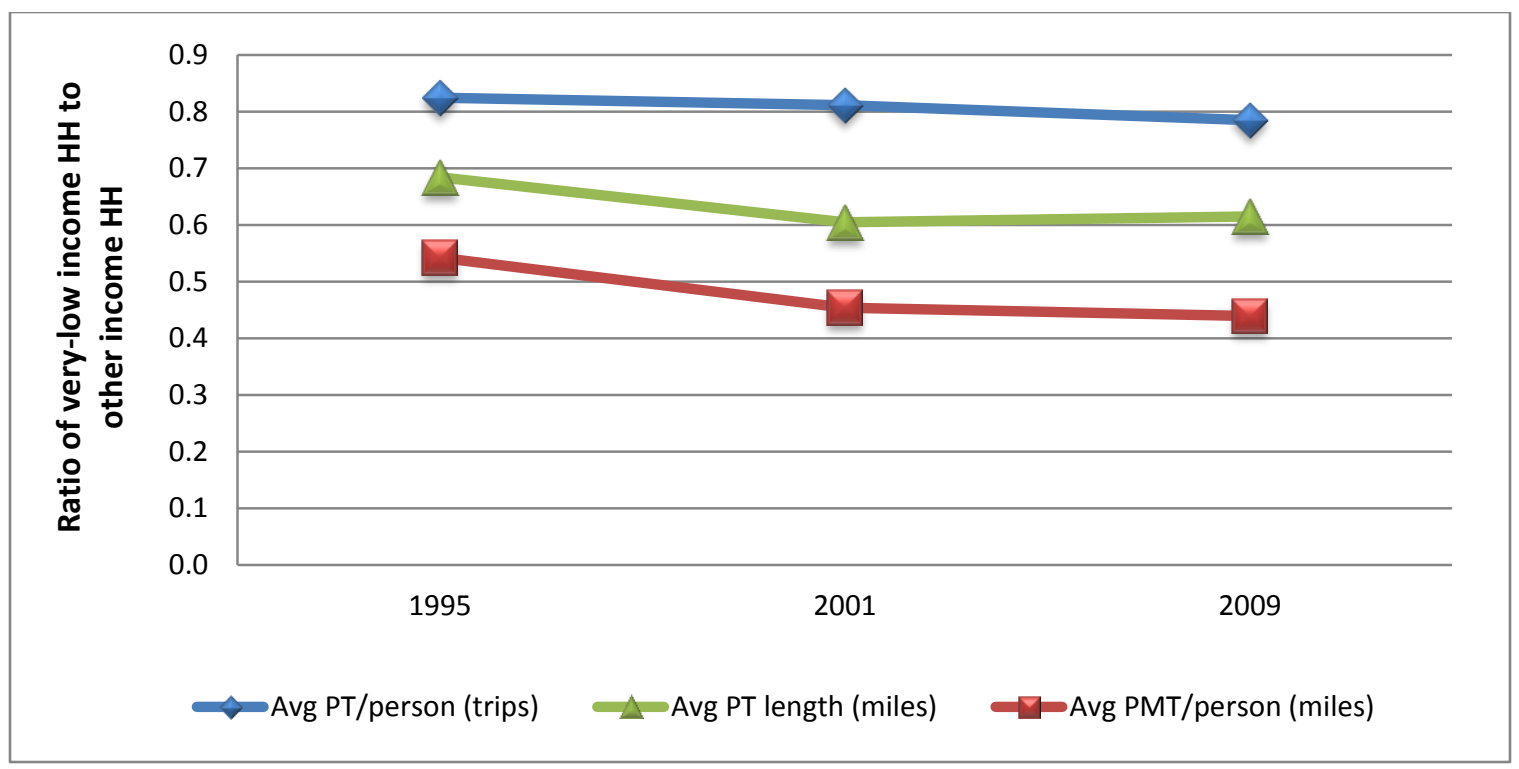

Figure 7-1. Mobility statistics for trips made by a very-low-income NYS resident, in relation to each trip made by an other-income person (NHTS data) 
* Drivers from a very-low income household in NYS took significantly fewer vehicle trips than their counterparts from other income households in all NHTS years.

* A typical very-low income driver from NYS made an average of only 1.7 vehicle-trips per day in 2009, which is a significant drop from the daily average of 2.1 vehicle-trips in 2001. During this time, a driver with other income level took a higher average of 2.6 vehicle-trips in 2009 with a decline from 3.1 vehicle-trips in 2001 (Figure 4-16 and Table 7-2).

* NYC drivers particularly took the least number of vehicle-trips than drivers from all other regions, regardless of whether they were within or outside of NYS (Figure 4-17).

* A very-low income driver was more likely to take vehicle trips for family/personal business activities, when compared to one from a higher income household. This is consistent across all regions (in and outside of NYS) and with all population densities considered in NYS (Table 4-5).

* According to 2009 NHTS data, a very-low income NYS driver traveled about 11.2 VMT on a daily basis, as compared to twice as many miles per day (22.6 miles) for an other income NYS driver in the same year (Figure 4-19 and Table 7-2).

* Specifically, higher income drivers from NYS are not only more likely to use a vehicle for work-related trips, they also traveled more miles in vehicles for that purpose, as compared to drivers from very-low income households in NYS with VMT of 8.0 miles versus 2.8 miles respectively (Figure 4-20).

Table 7-2. Mobility statistics for vehicle-trips taken by NYS residents by income status

\begin{tabular}{|c|c|c|c|}
\hline Travel Statistics - vehicle trips & 2009 & 2001 & 1995 \\
\hline \multicolumn{4}{|l|}{ Avg. VT/driver } \\
\hline Very-low income & 1.67 & 2.12 & 2.33 \\
\hline Other income & 2.55 & 2.82 & 3.05 \\
\hline$\%$ difference between income groups & $-34.7 \%$ & $-24.8 \%$ & $-23.6 \%$ \\
\hline \multicolumn{4}{|l|}{ Average VMT/driver } \\
\hline Very-low income & 11.22 & 15.51 & 16.71 \\
\hline Other income & 22.62 & 25.65 & 27.28 \\
\hline$\%$ difference between income groups & $-50.4 \%$ & $-39.5 \%$ & $-38.7 \%$ \\
\hline \multicolumn{4}{|l|}{ Average VT length (mile) } \\
\hline Very-low income & 6.95 & 7.63 & 7.33 \\
\hline Other income & 8.98 & 9.22 & 9.02 \\
\hline$\%$ difference between income groups & $-22.6 \%$ & $-17.2 \%$ & $-18.7 \%$ \\
\hline \multicolumn{4}{|c|}{ Average time spent in vehicle (those who drove in travel day, min.) } \\
\hline Very-low income & 67.92 & 81.20 & 67.25 \\
\hline Other income & 76.30 & 79.99 & 73.31 \\
\hline$\%$ difference between income groups & $-11.0 \%$ & $1.5 \%$ & $-8.3 \%$ \\
\hline
\end{tabular}

Drivers from a very-low income household in NYS traveled about 7 miles per vehicletrip on any typical day in 2009, while drivers with higher income traveled about 2 miles farther (29\% more distance) on each vehicle trip they took during the same year (Figure 4-21 and Table 7-2). 
Among drivers who drove on the travel day in 2009, those from very-low income households spent nearly 9 minutes less time in a vehicle as compared to time spent by their higher income counterpart drivers (Figure 4-23 and Table 7-2).

* As shown in Figure 7-2 for 2009, a typical very-low income NYS driver took fewer vehicle trips (0.7 trips), had less VMT (0.5 miles), made shorter vehicle trips (0.8 miles), and spent less time in vehicles ( 0.9 minutes) when compared to each vehicle-trip made by higher income NYS drivers in the same year.

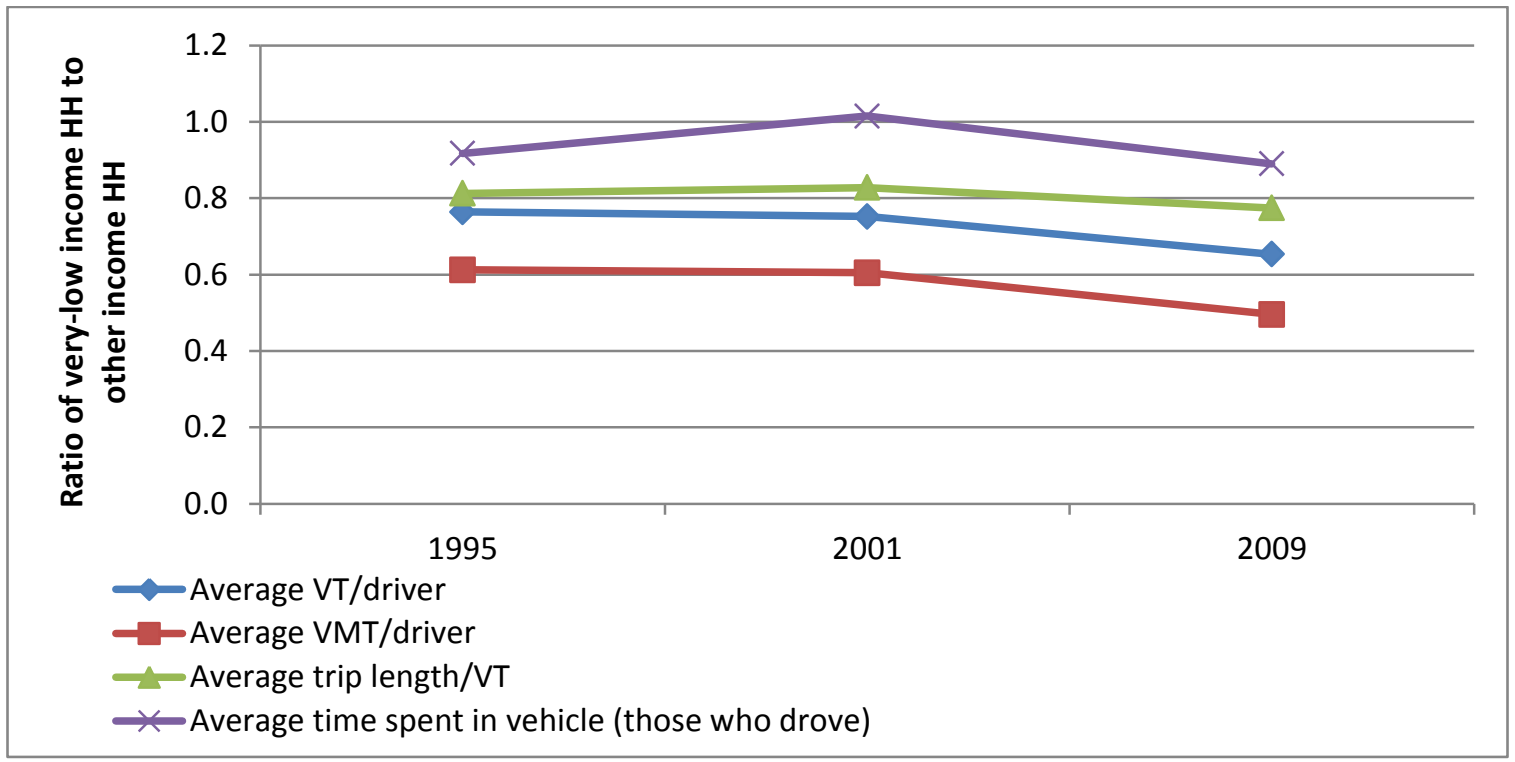

Figure 7-2. Mobility statistics for vehicle trips made by a very-low-income NYS driver, in relation to each trip made by an other-income driver (NHTS data)

\subsubsection{Accessibility \& Transportation Equality Issues}

\subsubsection{Access to Public Transit}

Essentially, 84\% of NYS's very-low income populations lived within a one-mile radius of transit stations, while only $17 \%$ of the other income New Yorkers lived within the same range (Section 5.1).

* Nearly $35 \%$ of all persons in NYC with income under $\$ 25,000$ used public transit, as compared to $13 \%$ for those who are in the $\$ 100,000+$ income category. Moreover, children from NYC households with income under $\$ 25,000$ had the highest likelihood of taking public transit (Figure 5-2).

* Elderly NYC residents with income under \$25,000 also have a higher likelihood of using public transit than their higher income neighbors, $23 \%$ versus $17 \%$ respectively (Figure 5-4).

- Nearly $43 \%$ of public transit trips made by higher income New Yorkers were for work, as compared to only $23 \%$ among public transit trips taken by those very-low income NYS 
residents. Aside from work trips, shares of public transit use by trip purpose were quite similar for New Yorkers from the two income categories (Figure 5-5 and Figure 5-6).

\subsubsection{Worker Commute Patterns}

* A very-low income worker from NYS made slightly more commute trips during a Friday-Sunday time period than a person from other income households in 2009. This may reflect that a lower income worker was more likely to be employed by lower-paying service sector employers, which tend to require more help during non-normal workdays, i.e., from Friday to Sunday (Figure 5-8).

* Typically, NYS workers spent less time on commute trips made in a POV, as compared to commuting by other non-walk modes of transportation, regardless of income status or location. Workers using public transit, on the other hand, generally spent the most time commuting (Table 5-1).

\subsubsection{Zero-Vehicle and Low-Income}

* About 50\% of the very-low income households in NYS did not own any vehicles. Most of these zero-vehicle very-low income households were located in NYC (Figure 3-12Figure 3-12).

* Most trips taken by individuals from zero-vehicle households within Manhattan in 2009 were made by walking, and accounted for $62 \%$ of all daily person-trips taken, regardless of income status (Figure 5-13).

* Outside of NYS, those from a zero-vehicle very-low income household also walked on $37 \%$ of their daily person trips (Figure 5-13).

\subsubsection{Mobility of Children in Poverty}

* Children (ages 5-15 years old) from a very-low income household in NYS traveled an average of 2.7 trips every day in 2009, as compared to 3.2 trips among higher income children from NYS. As a comparison, older New Yorkers (ages 16 years and older) from a very-low income household made an average of 3.2 trips on a daily basis in 2009, while their counterpart neighbors in other income group took 4.1 person-trips per day within the same year (Figure 5-15).

* The influence of income on travel frequencies seems to be less among children. Specifically, children of very-low income households made about $19 \%$ fewer trips than the higher income children did in 2009, as compared to $28 \%$ among those over 15 years old (Figure 5-15).

* Children traveled fewer miles on a daily basis than older persons within the same income class in NYS, with PMT of 9.6 miles versus 14.8 miles respectively among very-low income households and 21.1 miles versus 33.5 miles respectively for those from other incomes (Figure 5-16). 
* On a per-trip basis, NYS's very-low income children traveled about 3 miles shorter on each daily trip than their counterpart higher income neighbors in 2009 (Figure 5-17).

* Children from a very-low income household in NYS traveled less frequently and made shorter trips on a daily basis than trips made by all other children in the nation. Nearly half of the daily trips taken by a typical NYS very-low income child were walking or using public transit (Table 5.3).

\subsubsection{Lived-Alone Elderly with Very-Low Income}

* About half of the daily trips taken by a NYC single elderly person in a very-low income household were walking and another $24 \%$ were via public transit. On the other hand, daily trips made by NYC residents from a larger size very-low income elderly household were split almost equally among POVs, public transit, and walking (Figure 5-19).

* Individuals from a single-occupant, very-low income elderly household in NYC traveled shorter distances on a daily basis or per-trip basis, as compared to trips taken by their counterpart neighbors from a larger-size household (Figure 5-20).

* NYC drivers from a very-low income elderly household traveled significantly fewer POV trips than their counterpart New Yorkers who lived outside of NYC, regardless of household size (Figure 5-21).

\subsubsection{Views on Transportation Quality}

* Over three in five of those very-low income New Yorkers indicated "price of travel" as the most important issue for them, and expressed that it was a big problem. The issue of "aggressive/distracted drivers" was also expressed as a big issue by nearly $60 \%$ of the very-low income New Yorkers who identified this issue as their most important concern (Figure 6-1).

* The concern for "access/availability of public transit" was only considered a big issue by half of those very-low income NYS residents who identified it as their most important issue, however (Figure 6-1).

* Outside of NYS, the "price of travel" was reflected as a big issue by $65 \%$ of the very-low income individuals who said that "price of travel" was their most important concern (Figure 6-2).

* In all regions, except for Manhattan and Putnam-Rockland-Westchester, New Yorkers from a very-low income household were more likely to reflect "price of travel" as a big issue than the opinions expressed by their counterpart higher income neighbors (Figure 6-6). 
APPENDIX A. GLOSSARY 



\section{APPENDIX A. GLOSSARY}

This glossary provides the most commonly used terms in the NHTS and definitions for those terms. These definitions are provided to assist the user in the interpretation of NHTS data.

\section{Term Definition}

Adult

Block Group

Census Tract

Driver

Employed

Education Level

Household

Household Income

\section{Household Members}

For NHTS, this is defined as a person 18 years or older. A subdivision of a Census tract that averages 1000 to 1100 people, and approximately 400-500 housing units. The source used for the 2009 NHTS was TeleAtlas MatchMaker (derived from Census 2000 definition).

A small subdivision of a county, containing approximately 4,000 persons. Tracts can range in population from 2,500 to 8,000. The geographic size of the tract may vary considerably, depending on population density. Tracts were designed to be homogeneous in regard to population characteristics, economic status and living conditions when they were first delineated. Since the first tracts were delineated for the 1890 Census, today's tracts may be far from homogeneous. The source used for the 2009 NHTS was TeleAtlas MatchMaker (derived from Census 2000 definition).

A driver is a person who operates a motorized vehicle. If more than one person drives on a single trip, the person who drives the most miles is classified as the principal driver.

A person is considered employed if (s) he worked for pay, either full time or part time, during the week before the interview. This includes persons who work at home or persons who have more than one job.

The number of years of regular schooling completed in graded public, private, or parochial schools, or in colleges, universities, or professional schools, whether day school or night school. Regular schooling advances a person toward an elementary or high school diploma, or a college, university, or professional school degree.

A group of persons whose usual place of residence is a specific housing unit; these persons may or may not be related to each other. The total of all U.S. households represents the total civilian non-institutionalized population. A household does not include group quarters (i.e., 10 or more persons living together, none of whom are related).

Household income is the money earned by all family members in a household, including those temporarily absent. Annual income consisted of the income earned 12 months preceding the interview. Household income includes monies from all sources, such as wages and salary, commissions, tips, cash bonuses, income from a business or farm, pensions, dividends, interest, unemployment or workmen's compensation, social security, veterans' payments, rent received from owned property (minus the operating costs), public assistance payments, regular gifts of money from friends or relatives not living in the household, alimony, child support, and other kinds of periodic money income other than earnings. Household income excludes in-kind income such as room and board, insurance payments, lump-sum inheritances, occasional gifts of money from persons not living in the same household, withdrawal of savings from banks, tax refunds, and the proceeds of the sale of one's house, car, or other personal property.

Household members include all people, whether present or temporarily absent, whose usual place of residence is in the sample unit. Household members also 
Term

Household Vehicle

Journey-to-Work Trips (Commute trips)

Means of Transportation

\section{Definition}

include people staying in the sample unit who have no other usual place of residence elsewhere.

A household vehicle is a motorized vehicle that is owned, leased, rented or company-owned and available to be used regularly by household members during the two-week travel period. Household vehicles include vehicles used solely for business purposes or business-owned vehicles, so long as they are driven home and can be used for the home to work trip, (e.g., taxicabs, police cars, etc.). Household vehicles include all vehicles that were owned or available for use by members of the household during the travel period, even though a vehicle may have been sold before the interview. Vehicles excluded from household vehicles are those which were not working and were not expected to be working within 60 days, and vehicles that were purchased or received after the designated travel day.

Includes travel to and from a place where one reports for work. Does not include any other work-related travel. Does not include any trips for persons who work at home.

A mode of travel used for going from one place (origin) to another (destination). A means of transportation includes private and public transit modes, as well as walking.

The following transportation modes, grouped by major mode, are included in the NHTS data.

Private Vehicle - a stipulation for being a private vehicle is that the vehicle is privately owned or operated.

1. Car. Includes cars and station wagons. Leased and rented cars are included if they are privately operated and not used for picking up passengers in return for fare.

2. Van. Includes vans or minivans designed to carry 5 to 13 passengers, or to haul cargo.

3. Sport Utility Vehicle. Includes vehicles that are a hybrid of design elements from a van, a pickup truck and a station wagon. Examples include a Ford Explorer, Jeep Cherokee, or Nissan Pathfinder.

4. Pickup Truck. Includes vehicles with an enclosed cab that usually accommodates 2-3 passengers, and has an open cargo area in the rear. Late model pickups often have a back seat that allows for total seating of $4-6$ passengers. Pickup trucks usually have the same size of wheelbase as a full-size station wagon. This category also includes pickups with campers.

5. Other Truck: This category consists of all trucks other than pickup trucks (i.e., dump trucks, trailer trucks, etc.).

6. RV or Motor Home: An RV or motor home includes a self-powered recreational vehicle that is operated as a unit without being towed by another vehicle (e.g., a Winnebago motor home).

7. Motorcycle: This category includes large, medium, and small motorcycles and mopeds.

8. Golf Cart: This includes all electric or gas operated vehicles designed for use on a golf course, but whose use has recently extended to use within smaller, often gated, communities.

Public Transportation, as used in FHWA publications and analysis of NHTS 
data, typically includes the following that are indicated in bold below, mass transit bus, commuter bus, commuter train, subway/elevated rail, and streetcar/trolley.

Bus. This category includes:

9. mass transit systems, these are local public transit buses that are available to the general public,

10. commuter buses, these are buses used for short-distance public transport purposes (e.g., city bus or public bus),school buses, and

12. charter/tour buses, these are private buses operating on a fixed schedule between population centers, and

13. city to city buses, these are buses that run from one urban center to the other (e.g., Greyhound), and

14. shuttle buses, these are buses that shuttle passengers from one fixed place to another (e.g., airport shuttles).

Train: This category includes:

15. Amtrak/Intercity Train that run from one urban center to another,

16. Commuter trains and passenger trains

17. Subway and elevated rail (also known as rail rapid transit) is a high capacity system operated on a fixed rail or guide way system on a private right of way, and

18. Trolley/streetcars are vehicles that run on a fixed rail system powered by electricity obtained from an overhead power distribution system.

\section{Other Modes}

11. School Buses.

19. Taxi. Taxis include the use of a taxicab by a passenger for fare, including limousines. The taxi category does not include rental cars if they are privately operated.

20. Ferry. This includes travel by passenger line ferries.

21. Airplane. . Airplanes include commercial airplanes and smaller planes that are available for use by the general public in exchange for a fare. Private and corporate planes and helicopters are also included.

22. Bicycle: This category includes bicycles of all speeds and sizes that do not have a motor.

23. Walk: This category includes walking and jogging.

24. Special Transit for People with Disabilities. This includes things like "Dial-A-Ride"

\section{Metropolitan Statistical Area (MSA)}

Motorized Vehicle
97. Other. Includes any type of transportation not previously listed, (e.g. skate boards, roller blades, sailboats, cruise ships, etc).

Except in the New England States, a Metropolitan Statistical Area is a county or group of contiguous counties which contains at least one city of 50,000 inhabitants or more, or "twin cities" with a combined population of at least 50,000. In addition, contiguous counties are included in an MSA if, according to certain criteria, they are socially and economically integrated with the central city. In the New England States, MSA's consist of towns and cities instead of counties. The source used for the 2009 NHTS was 1999 Metropolitan Areas: Cartographic Boundary Files. File ma99_99.shp from http://www.census.gov/geo/www/cob/ma1999.html. Motorized vehicles are all vehicles that are licensed for highway driving. Snow mobiles and minibikes are specifically excluded. 
Term

New York City

New York State

Metro Area

Passenger

Person Miles of

Travel (PMT)

\section{Person Trip}

POV

Travel Day

Travel Day Trip

Travel Day Trip Purpose

\section{Definition}

New York City is defined in this report as the five county area: Bronx, Kings, Queens, New York (Manhattan), and Richmond.

The New York State Metro area includes the following three areas: (1) Nassau, Suffolk; (2) New York City, (which includes the following counties: Bronx, Kings, Queens, New York, and Richmond); and (3) Putnam, Rockland, and Westchester.

For a specific trip, a passenger is any occupant of a motorized vehicle, other than the driver.

PMT is a primary measure of person travel. When one person travels one mile, one person mile of travel results. Where 2 or more persons travel together in the same vehicle, each person makes the same number of person miles as the vehicle miles. Therefore, four persons traveling 5 miles in the same vehicle results in 20 person miles $(4 \times 5=20)$.

A person trip is a trip by one or more persons in any mode of transportation. Each person is considered as making one person trip. For example, four persons traveling together in one auto are counted as four person trips. A privately-owned vehicle or privately-operated vehicle. Either way, the intent here is that this is not a vehicle available to the public for a fee, such as a bus, subway, taxi, etc.

A travel day is a 24-hour period from 4:00 a.m. to 3:59 a.m. designated as the reference period for studying trips and travel by members of a sampled household.

A travel day trip is defined as any time the respondent went from one address to another by private motor vehicle, public transportation, bicycle, walking, or other means. However, a separate trip is not counted in two instances:

1. When the sole purpose for the trip is to get to another vehicle or mode of transportation in order to continue to the destination.

2. Travel within a shopping center, mall or shopping areas of 4-5 blocks is to be considered as travel to one destination.

A trip purpose is the main reason that motivates a trip. There are 36 travel day trip purposes used in the 2009 NHTS.

Trip purposes were collected using a From-To approach. For each trip, the origin and destination are on the file in specific terms if reported by the respondent (e.g. from work to Bob's Beef Pit). The 36 trip reasons are defined below. The numbers in parentheses represent the value of WHYTO (trip purpose) in the dataset.

1. To Home (01). Represents a trip to the respondents' primary residence.

2. Go to Work (11). This is the first trip to the work location on travel day.

3. Return to Work (12). A trip to work that is not the first trip to the workplace on the travel day (e.g., returning to work after lunch).

4. Attend Business Meeting/Trip (13). Represents a work related trip whose purpose is to attend a business meeting.

5. Other Work Related (14). A work related trip whose purpose is not specified. 
6. Go to School as a Student (21). Represents a trip whose purpose is to go to school as a student.

7. Go to Religious Activity (22). Represents a trip whose purpose is to go to a place to attend a religious activity.

8. Go to Library, School Related (23). Represents a trip whose purpose is to go to the library as part of a school related activity.

Go to Daycare/Before or After School Care (24). Represents a trip

9. whose purpose is to attend day care or a supervised before or after school care program

10. Other School/Religious Activity (20). Represents school and religious activities that are not captured in WHYTO 21-24 above.

Medical/Dental Services (30). Represents a trip made to obtain

11. medical, dental, or mental health treatment, or other related professional services.

Buy Goods: groceries/clothing/hardware store (41). Represents a

12. shopping trip whose purpose is to purchase commodities for use or consumption elsewhere. This purpose also includes all shopping trips even if nothing is purchased.

Buy Services: video rentals/dry cleaning/post office/car service/bank

13. (42). This category includes the purchase of services other than medical/dental or other professional services.

14. Buy Gas (43). Represents a trip made specifically to get gas.

15. Shopping/Errands (40). Represents shopping and errand trips that are not captured in WHYTO 41-43 above.

16. Go to the Gym/Exercise/Play Sports (51). Represents a trip made for exercise, to engage in exercise or to participate in a sport.

Rest or Relaxation/Vacation (52). Represents a trip made for the

17. purpose of relaxing or taking a vacation, but does not include visiting family.

18. Visit Friends/Relatives (53). Represents the social/recreational trip whose purpose is to visit with family and friends.

Go out/Hang out: entertainment/theater/sports event/go to bar (54).

19. Represents trips whose purpose is entertainment related or hanging out with friends. Typically this event takes place in a public venue.

20. Visit Public Place: historical site/museum/park/library (55).

Represents a trip purpose that is educational or enlightening.

21. Social/Recreational (50). This category includes social and recreational trips that are not captured in WHYTO 51-55 above. 
Use Professional Services: attorney/accountant (61). Represents a trip

22. made for to engage professional services other than for medical/dental purposes.

23. Attend Funeral/Wedding (62). Represents a trip whose purpose is to attend a funeral or a wedding.

24. Use Personal Services: grooming/haircut/nails (63). Represents a trip for personal services such as to get a massage or get a haircut.

25. Pet Care: walk the dog/vet visits (64).

Attend Meeting: PTA/home owner's association/local government

26. (65). Represents a trip purpose to attend a non-work related meeting, such as a community meeting

27. Family Personal Business/Obligations (60). Represents a trip for 13 personal business but is not captured in WHYTO 61-65 above.

28. Pickup Someone (71). Represents a trip whose purpose was to pick up a passenger.

Take and Wait (72). Represents a trip made to take someone to a

29. destination and then wait with or for them at the destination and then depart together.

30. Drop Someone Off (73). Represents a trip whose purpose was to drop off a passenger (but not wait for them).

Transport Someone (70). Represents trips with a passenger that are

31. related to picking up or dropping off someone but is not captured in WHYTO 71-73 above.

32. Social Event (81). Represents a trip whose purpose is to attend a social event but eating a meal is not a key component of the event.

33. Get/Eat Meal (82). Represents a trip whose primary purpose is to get and eat a meal.

34. Coffee/Ice Cream/Snacks (83). Represents a trip whose purpose is to get/eat a snack or drink, something less than a meal.

35. Meals (80). Represents a trip whose purpose is to eat or get a meal but is not captured in WHYTO 81-83 above.

36. Other (97). Represents a trip purpose not captured by any of the specific WHYTO categories described above.

Urbanized Area

An urbanized area consists of the built up area surrounding a central core (or central city), with a population density of at least 1,000 persons per square mile. Urbanized areas do not follow jurisdictional boundaries thus it is common for the urbanized area boundary to divide a county.

For the 2009 NHTS, Urban Areas were calculated two ways. 
Term

Vehicle

Vehicle Miles of Travel (VMT)

Vehicle Occupancy

Vehicle Trip

Worker

\section{Definition}

- Variable URBAN uses the 2000 Urbanized Areas: Cartographic Boundary Files. File ua00_d00.shp from http://www.census.gov/geo/www/cob/ua2000.html. Two codes are used: $0=$ Not in Urban Area, $1=$ in Urban Area

- Variable URBAN1 uses the 2000 Urbanized Areas: Cartographic Boundary Files. File ua00_d00.shp from http://www.census.gov/geo/www/cob/ua2000.html. Three codes are used: $0=$ Not in Urban Area, $1=$ in Urban Cluster, $2=$ in Urban Area, $3=$ in area surrounded by urban areas.

In the 2009 NHTS, the term vehicle includes autos, passenger vans, sport utility vehicles, pickups and other light trucks, RV's, motorcycles and mopeds owned or available to the household.

VMT is a unit to measure vehicle travel made by a private vehicle, such as an automobile, van, pickup truck, or motorcycle. Each mile traveled is counted as one vehicle mile regardless of the number of persons in the vehicle.

Vehicle occupancy is the number of persons, including driver and passenger(s) in a vehicle; also includes persons who did not complete a whole trip. NHTS occupancy rates are generally calculated as person miles divided by vehicle miles.

A trip by a single privately-operated vehicle (POV) regardless of the number of persons in the vehicle.

See "Employed." 



\section{APPENDIX B. SUPPLEMENTAL TABLES AND FIGURES}



Table B-1A. 2009 HUD very low income cutoffs, New York State

\begin{tabular}{|c|c|c|c|c|c|c|c|c|c|c|}
\hline \multirow[b]{2}{*}{ Type } & \multirow[b]{2}{*}{ Name } & \multirow[b]{2}{*}{ FY2009MFI } & \multicolumn{8}{|c|}{ Number of Persons } \\
\hline & & & 1 & 2 & 3 & 4 & 5 & 6 & 7 & 8 \\
\hline MSA & Albany-Schenectady-Troy, NY MSA & 74100 & 25950 & 29650 & 33350 & 37050 & 40000 & 43000 & 45950 & 48900 \\
\hline MSA & Binghamton, NY MSA & 58600 & 20500 & 23450 & 26350 & 29300 & 31650 & 34000 & 36350 & 38700 \\
\hline MSA & Buffalo-Niagara Falls, NY MSA & 63500 & 22250 & 25400 & 28600 & 31750 & 34300 & 36850 & 39350 & 41900 \\
\hline MSA & Glens Falls, NY MSA & 59400 & 20800 & 23750 & 26750 & 29700 & 32100 & 34450 & 36850 & 39200 \\
\hline MSA & Ithaca, NY MSA & 71300 & 25150 & 28700 & 32300 & 35900 & 38750 & 41650 & 44500 & 47400 \\
\hline MSA & Kingston, NY MSA & 69700 & 24400 & 27900 & 31350 & 34850 & 37650 & 40450 & 43200 & 46000 \\
\hline MSA & Poughkeepsie-Newburgh-Middletown, NY MSA & 81800 & 28650 & 32700 & 36800 & 40900 & 44150 & 47450 & 50700 & 54000 \\
\hline MSA & Rochester, NY MSA & 66500 & 23300 & 26600 & 29950 & 33250 & 35900 & 38550 & 41250 & 43900 \\
\hline MSA & Syracuse, NY MSA & 63700 & 22300 & 25500 & 28650 & 31850 & 34400 & 36950 & 39500 & 42050 \\
\hline MSA & Utica-Rome, NY MSA & 55800 & 19550 & 22300 & 25100 & 27900 & 30150 & 32350 & 34600 & 36850 \\
\hline AREA & Nassau-Suffolk, NY HUD Metro FMR Area & 101800 & 35650 & 40700 & 45800 & 50900 & 54950 & 59050 & 63100 & 67200 \\
\hline AREA & New York, NY HUD Metro FMR Area & 61600 & 26900 & 30700 & 34550 & 38400 & 41450 & 44550 & 47600 & 50700 \\
\hline AREA & Rockland County, NY HUD Metro FMR Area & 102000 & 35700 & 40800 & 45900 & 51000 & 55100 & 59150 & 63250 & 67300 \\
\hline AREA & Westchester County, NY Statutory Exception Area & 105300 & 36850 & 42100 & 47400 & 52650 & 56850 & 61050 & 65300 & 69500 \\
\hline COUNTY & Allegany County, NY & 50700 & 19200 & 21950 & 24700 & 27450 & 29650 & 31850 & 34050 & 36250 \\
\hline COUNTY & Cattaraugus County, NY & 51000 & 19200 & 21950 & 24700 & 27450 & 29650 & 31850 & 34050 & 36250 \\
\hline COUNTY & Cayuga County, NY & 58900 & 20600 & 23550 & 26500 & 29450 & 31800 & 34150 & 36500 & 38850 \\
\hline COUNTY & Chautauqua County, NY & 51900 & 19200 & 21950 & 24700 & 27450 & 29650 & 31850 & 34050 & 36250 \\
\hline COUNTY & Chenango County, NY & 53700 & 19200 & 21950 & 24700 & 27450 & 29650 & 31850 & 34050 & 36250 \\
\hline COUNTY & Clinton County, NY & 60900 & 21300 & 24350 & 27400 & 30450 & 32900 & 35300 & 37750 & 40200 \\
\hline COUNTY & Columbia County, NY & 65400 & 22900 & 26150 & 29450 & 32700 & 35300 & 37950 & 40550 & 43150 \\
\hline COUNTY & Cortland County, NY & 56800 & 19900 & 22700 & 25550 & 28400 & 30650 & 32950 & 35200 & 37500 \\
\hline COUNTY & Delaware County, NY & 51700 & 19200 & 21950 & 24700 & 27450 & 29650 & 31850 & 34050 & 36250 \\
\hline COUNTY & Elmira, NY MSA & 55500 & 19450 & 22200 & 25000 & 27750 & 29950 & 32200 & 34400 & 36650 \\
\hline COUNTY & Essex County, NY & 55200 & 19300 & 22100 & 24850 & 27600 & 29800 & 32000 & 34200 & 36450 \\
\hline COUNTY & Franklin County, NY & 50200 & 19200 & 21950 & 24700 & 27450 & 29650 & 31850 & 34050 & 36250 \\
\hline COUNTY & Fulton County, NY & 50900 & 19200 & 21950 & 24700 & 27450 & 29650 & 31850 & 34050 & 36250 \\
\hline COUNTY & Genesee County, NY & 59200 & 21750 & 24850 & 27950 & 31050 & 33550 & 36000 & 38500 & 41000 \\
\hline COUNTY & Greene County, NY & 57500 & 20150 & 23000 & 25900 & 28750 & 31050 & 33350 & 35650 & 37950 \\
\hline COUNTY & Hamilton County, NY & 52100 & 19200 & 21950 & 24700 & 27450 & 29650 & 31850 & 34050 & 36250 \\
\hline COUNTY & Jefferson County, NY & 51200 & 19200 & 21950 & 24700 & 27450 & 29650 & 31850 & 34050 & 36250 \\
\hline COUNTY & Lewis County, NY & 50200 & 19200 & 21950 & 24700 & 27450 & 29650 & 31850 & 34050 & 36250 \\
\hline
\end{tabular}




$\begin{array}{ll}\text { COUNTY } & \text { Montgomery County, NY } \\ \text { COUNTY } & \text { Otsego County, NY } \\ \text { COUNTY } & \text { Schuyler County, NY } \\ \text { COUNTY } & \text { Seneca County, NY } \\ \text { COUNTY } & \text { St. Lawrence County, NY } \\ \text { COUNTY } & \text { Steuben County, NY } \\ \text { COUNTY } & \text { Sullivan County, NY } \\ \text { COUNTY } & \text { Wyoming County, NY } \\ \text { COUNTY } & \text { Yates County, NY }\end{array}$

\begin{tabular}{l|llllllll}
54400 & 22200 & 25400 & 28550 & 31750 & 34250 & 36800 & 39350 & 41900 \\
54700 & 19200 & 21950 & 24700 & 27450 & 29650 & 31850 & 34050 & 36250 \\
54500 & 19200 & 21950 & 24700 & 27450 & 29650 & 31850 & 34050 & 36250 \\
57200 & 20000 & 22900 & 25750 & 28600 & 30900 & 33200 & 35450 & 37750 \\
49600 & 19200 & 21950 & 24700 & 27450 & 29650 & 31850 & 34050 & 36250 \\
53800 & 20050 & 22900 & 25800 & 28650 & 30950 & 33250 & 35550 & 37800 \\
59100 & 20700 & 23650 & 26600 & 29550 & 31900 & 34300 & 36650 & 39000 \\
59300 & 20750 & 23700 & 26700 & 29650 & 32000 & 34400 & 36750 & 39150 \\
53000 & 19200 & 21950 & 24700 & 27450 & 29650 & 31850 & 34050 & 36250
\end{tabular}


Table B-1B. 2001 HUD Very low income cutoffs, New York State

\begin{tabular}{|c|c|c|c|c|c|c|c|c|c|c|}
\hline TYPE & NAME & FY95MFI & $\begin{array}{l}1 \\
\text { PERSON }\end{array}$ & $\begin{array}{l}2 \\
\text { PERSON }\end{array}$ & $\begin{array}{l}3 \\
\text { PERSON }\end{array}$ & $\begin{array}{l}4 \\
\text { PERSON }\end{array}$ & $\begin{array}{l}5 \\
\text { PERSON }\end{array}$ & $\begin{array}{l}6 \\
\text { PERSON }\end{array}$ & $\begin{array}{l}7 \\
\text { PERSON }\end{array}$ & $\begin{array}{l}8 \\
\text { PERSON }\end{array}$ \\
\hline PMSA & Buffalo-Niagara Falls, NY & 48400 & 16950 & 19350 & 21800 & 24200 & 26150 & 28050 & 30000 & 31950 \\
\hline PMSA & Dutchess County, NY & 63400 & 22200 & 25350 & 28550 & 31700 & 34250 & 36750 & 39300 & 41850 \\
\hline PMSA & Nassau-Suffolk, NY & 78700 & 27550 & 31500 & 35400 & 39350 & 42500 & 45650 & 48800 & 51950 \\
\hline PMSA & New York, NY & 59100 & 20700 & 23650 & 26600 & 29550 & 31900 & 34300 & 36650 & 39000 \\
\hline PMSA & Newburgh, NY-PA & 55800 & 19550 & 22300 & 25100 & 27900 & 30150 & 32350 & 34600 & 36850 \\
\hline MSA & Albany-Schenectady-Troy, NY & 53000 & 18550 & 21200 & 23850 & 26500 & 28600 & 30750 & 32850 & 35000 \\
\hline MSA & Binghamton, NY & 44700 & 15650 & 17900 & 20100 & 22350 & 24150 & 25950 & 27700 & 29500 \\
\hline MSA & Elmira, NY & 43200 & 15100 & 17300 & 19450 & 21600 & 23350 & 25050 & 26800 & 28500 \\
\hline MSA & Glens Falls, NY & 44200 & 15450 & 17700 & 19900 & 22100 & 23850 & 25650 & 27400 & 29150 \\
\hline MSA & Jamestown, NY & 39600 & 14500 & 16550 & 18650 & 20700 & 22350 & 24000 & 25650 & 27300 \\
\hline MSA & Rochester, NY & 52900 & 18500 & 21150 & 23800 & 26450 & 28550 & 30700 & 32800 & 34900 \\
\hline MSA & Syracuse, NY & 47900 & 16750 & 19150 & 21550 & 23950 & 25850 & 27800 & 29700 & 31600 \\
\hline MSA & Utica-Rome, NY & 40500 & 14500 & 16550 & 18650 & 20700 & 22350 & 24000 & 25650 & 27300 \\
\hline AREA & Rockland County, NY & 85400 & 29400 & 33600 & 37800 & 42000 & 45350 & 48700 & 52100 & 55450 \\
\hline AREA & Westchester County, NY & 85800 & 30050 & 34300 & 38600 & 42900 & 46350 & 49750 & 53200 & 56650 \\
\hline COUNTY & Allegany County & 37000 & 14500 & 16550 & 18650 & 20700 & 22350 & 24000 & 25650 & 27300 \\
\hline COUNTY & Cattaraugus County & 38200 & 14500 & 16550 & 18650 & 20700 & 22350 & 24000 & 25650 & 27300 \\
\hline COUNTY & Chenango County & 40000 & 14500 & 16550 & 18650 & 20700 & 22350 & 24000 & 25650 & 27300 \\
\hline COUNTY & Clinton County & 44200 & 15450 & 17700 & 19900 & 22100 & 23850 & 25650 & 27400 & 29150 \\
\hline COUNTY & Columbia County & 48700 & 17050 & 19500 & 21900 & 24350 & 26300 & 28250 & 30200 & 32150 \\
\hline COUNTY & Cortland County & 44300 & 15500 & 17700 & 19950 & 22150 & 23900 & 25700 & 27450 & 29250 \\
\hline COUNTY & Delaware County & 39000 & 14500 & 16550 & 18650 & 20700 & 22350 & 24000 & 25650 & 27300 \\
\hline COUNTY & Essex County & 39000 & 14500 & 16550 & 18650 & 20700 & 22350 & 24000 & 25650 & 27300 \\
\hline COUNTY & Franklin County & 37600 & 14500 & 16550 & 18650 & 20700 & 22350 & 24000 & 25650 & 27300 \\
\hline COUNTY & Fulton County & 38700 & 14500 & 16550 & 18650 & 20700 & 22350 & 24000 & 25650 & 27300 \\
\hline COUNTY & Greene County & 44200 & 15450 & 17700 & 19900 & 22100 & 23850 & 25650 & 27400 & 29150 \\
\hline COUNTY & Hamilton County & 36900 & 14500 & 16550 & 18650 & 20700 & 22350 & 24000 & 25650 & 27300 \\
\hline COUNTY & Jefferson County & 38600 & 14500 & 16550 & 18650 & 20700 & 22350 & 24000 & 25650 & 27300 \\
\hline
\end{tabular}




$\begin{array}{ll}\text { COUNTY } & \text { Lewis County } \\ \text { COUNTY } & \text { Otsego County } \\ \text { COUNTY } & \text { St. Lawrence County } \\ \text { COUNTY } & \text { Schuyler County } \\ \text { COUNTY } & \text { Seneca County } \\ \text { COUNTY } & \text { Steuben County } \\ \text { COUNTY } & \text { Sullivan County } \\ \text { COUNTY } & \text { Tompkins County } \\ \text { COUNTY } & \text { Ulster County } \\ \text { COUNTY } & \text { Wyoming County } \\ \text { COUNTY } & \text { Yates County }\end{array}$

\begin{tabular}{l|llllllll|}
38000 & 14500 & 16550 & 18650 & 20700 & 22350 & 24000 & 25650 & 27300 \\
42600 & 14900 & 17050 & 19150 & 21300 & 23000 & 24700 & 26400 & 28100 \\
38600 & 14500 & 16550 & 18650 & 20700 & 22350 & 24000 & 25650 & 27300 \\
38300 & 14500 & 16550 & 18650 & 20700 & 22350 & 24000 & 25650 & 27300 \\
44800 & 15700 & 17900 & 20150 & 22400 & 24200 & 26000 & 27800 & 29550 \\
42000 & 14700 & 16800 & 18900 & 21000 & 22700 & 24350 & 26050 & 27700 \\
45100 & 15800 & 18050 & 20300 & 22550 & 24350 & 26150 & 27950 & 29750 \\
52400 & 18350 & 20950 & 23600 & 26200 & 28300 & 30400 & 32500 & 34600 \\
44500 & 15600 & 17800 & 20050 & 22250 & 24050 & 25800 & 27600 & 29350 \\
41700 & 14600 & 16700 & 18750 & 20850 & 22500 & 24200 & 25850 & 27500 \\
39900 & 14500 & 16550 & 18650 & 20700 & 22350 & 24000 & 25650 & 27300
\end{tabular}


Table B-1C. 1995 HUD very low income cutoffs, New York State

\begin{tabular}{|c|c|c|c|c|c|c|c|c|c|c|}
\hline TYPE & NAME & FY95MFI & $\begin{array}{c}1 \\
\text { PERSON }\end{array}$ & $\begin{array}{c}2 \\
\text { PERSON }\end{array}$ & $\begin{array}{c}3 \\
\text { PERSON } \\
\end{array}$ & $\begin{array}{c}4 \\
\text { PERSON }\end{array}$ & $\begin{array}{c}5 \\
\text { PERSON }\end{array}$ & $\begin{array}{c}6 \\
\text { PERSON }\end{array}$ & $\begin{array}{c}7 \\
\text { PERSON } \\
\end{array}$ & $\begin{array}{c}8 \\
\text { PERSON }\end{array}$ \\
\hline PMSA & Buffalo-Niagara Falls, NY & 39000 & 13650 & 15600 & 17550 & 19500 & 21050 & 22600 & 24200 & 25750 \\
\hline PMSA & Dutchess County, NY & 54800 & 19200 & 21900 & 24650 & 27400 & 29600 & 31800 & 34000 & 36150 \\
\hline PMSA & Nassau-Suffolk, NY & 63400 & 22200 & 25350 & 28550 & 31700 & 34250 & 36750 & 39300 & 41850 \\
\hline PMSA & New York, NY & 43000 & 17150 & 19600 & 22050 & 24500 & 26450 & 28400 & 30400 & 32350 \\
\hline PMSA & Newburgh, NY-PA & 48800 & 17100 & 19500 & 21950 & 24400 & 26350 & 28300 & 30250 & 32200 \\
\hline MSA & Albany-Schenectady-Troy, NY & 43800 & 15350 & 17500 & 19700 & 21900 & 23650 & 25400 & 27150 & 28900 \\
\hline MSA & Binghamton, NY & 39900 & 13950 & 15950 & 17950 & 19950 & 21550 & 23150 & 24750 & 26350 \\
\hline MSA & Elmira, NY & 35600 & 12450 & 14250 & 16000 & 17800 & 19200 & 20650 & 22050 & 23500 \\
\hline MSA & Glens Falls, NY & 37800 & 13250 & 15100 & 17000 & 18900 & 20400 & 21900 & 23450 & 24950 \\
\hline MSA & Jamestown, NY & 33300 & 12300 & 14050 & 15800 & 17550 & 18950 & 20350 & 21750 & 23150 \\
\hline MSA & Rochester, NY & 45400 & 15900 & 18150 & 20450 & 22700 & 24500 & 26350 & 28150 & 29950 \\
\hline MSA & Syracuse, NY & 41400 & 14500 & 16550 & 18650 & 20700 & 22350 & 24000 & 25650 & 27300 \\
\hline MSA & Utica-Rome, NY & 35200 & 12300 & 14100 & 15850 & 17600 & 19000 & 20400 & 21800 & 23250 \\
\hline AREA & Westchester County, NY & 66900 & 23400 & 26750 & 30100 & 33450 & 36150 & 38800 & 41500 & 44150 \\
\hline COUNTY & Allegany County & 31200 & 12300 & 14050 & 15800 & 17550 & 18950 & 20350 & 21750 & 23150 \\
\hline COUNTY & Cattaraugus County & 31300 & 12300 & 14050 & 15800 & 17550 & 18950 & 20350 & 21750 & 23150 \\
\hline COUNTY & Chenango County & 34500 & 12300 & 14050 & 15800 & 17550 & 18950 & 20350 & 21750 & 23150 \\
\hline COUNTY & Clinton County & 35400 & 12400 & 14150 & 15950 & 17700 & 19100 & 20550 & 21950 & 23350 \\
\hline COUNTY & Columbia County & 39100 & 13700 & 15650 & 17600 & 19550 & 21100 & 22700 & 24250 & 25800 \\
\hline COUNTY & Cortland County & 36300 & 12700 & 14500 & 16350 & 18150 & 19600 & 21050 & 22500 & 23950 \\
\hline COUNTY & Delaware County & 31700 & 12300 & 14050 & 15800 & 17550 & 18950 & 20350 & 21750 & 23150 \\
\hline COUNTY & Essex County & 33100 & 12300 & 14050 & 15800 & 17550 & 18950 & 20350 & 21750 & 23150 \\
\hline COUNTY & Franklin County & 30100 & 12300 & 14050 & 15800 & 17550 & 18950 & 20350 & 21750 & 23150 \\
\hline COUNTY & Fulton County & 32400 & 12300 & 14050 & 15800 & 17550 & 18950 & 20350 & 21750 & 23150 \\
\hline COUNTY & Greene County & 35400 & 12400 & 14150 & 15950 & 17700 & 19100 & 20550 & 21950 & 23350 \\
\hline COUNTY & Hamilton County & 30600 & 12300 & 14050 & 15800 & 17550 & 18950 & 20350 & 21750 & 23150 \\
\hline COUNTY & Jefferson County & 32800 & 12300 & 14050 & 15800 & 17550 & 18950 & 20350 & 21750 & 23150 \\
\hline COUNTY & Lewis County & 32500 & 12300 & 14050 & 15800 & 17550 & 18950 & 20350 & 21750 & 23150 \\
\hline
\end{tabular}




\begin{tabular}{|c|c|c|c|c|c|c|c|c|c|c|}
\hline TYPE & NAME & FY95MFI & $\begin{array}{c}1 \\
\text { PERSON }\end{array}$ & $\begin{array}{c}2 \\
\text { PERSON }\end{array}$ & $\begin{array}{c}3 \\
\text { PERSON }\end{array}$ & $\begin{array}{c}4 \\
\text { PERSON }\end{array}$ & $\begin{array}{c}5 \\
\text { PERSON } \\
\end{array}$ & $\begin{array}{c}6 \\
\text { PERSON }\end{array}$ & $\begin{array}{c}7 \\
\text { PERSON }\end{array}$ & $\begin{array}{c}8 \\
\text { PERSON }\end{array}$ \\
\hline COUNTY & Otsego County & 34900 & 12300 & 14050 & 15800 & 17550 & 18950 & 20350 & 21750 & 23150 \\
\hline COUNTY & Schuyler County & 32800 & 12300 & 14050 & 15800 & 17550 & 18950 & 20350 & 21750 & 23150 \\
\hline COUNTY & Seneca County & 37000 & 12950 & 14800 & 16650 & 18500 & 20000 & 21450 & 22950 & 24400 \\
\hline COUNTY & St. Lawrence County & 32200 & 12300 & 14050 & 15800 & 17550 & 18950 & 20350 & 21750 & 23150 \\
\hline COUNTY & Steuben County & 33600 & 12300 & 14050 & 15800 & 17550 & 18950 & 20350 & 21750 & 23150 \\
\hline COUNTY & Sullivan County & 37700 & 13200 & 15100 & 16950 & 18850 & 20350 & 21850 & 23350 & 24900 \\
\hline COUNTY & Tompkins County & 42100 & 14750 & 16850 & 18950 & 21050 & 22750 & 24400 & 26100 & 27800 \\
\hline COUNTY & Ulster County & 44500 & 15600 & 17800 & 20000 & 22250 & 24050 & 25800 & 27600 & 29350 \\
\hline COUNTY & Wyoming County & 35000 & 12300 & 14050 & 15800 & 17550 & 18950 & 20350 & 21750 & 23150 \\
\hline COUNTY & Yates County & 32300 & 12300 & 14050 & 15800 & 17550 & 18950 & 20350 & 21750 & 23150 \\
\hline
\end{tabular}

Table B-2. Census poverty thresholds for 2009 by size of family and number of related children under 18 years

\begin{tabular}{|c|c|c|c|c|c|c|c|c|c|c|}
\hline \multirow{2}{*}{ Size of family unit } & \multirow[b]{2}{*}{$\begin{array}{l}\text { Weighted } \\
\text { Average } \\
\text { Thresholds }\end{array}$} & \multicolumn{9}{|c|}{ Related children under 18 years } \\
\hline & & None & One & Two & Three & Four & Five & Six & Seven & $\begin{array}{l}\text { Eight } \\
\text { or more }\end{array}$ \\
\hline One person (unrelated individual)... & 10,956 & & & & & & & & & \\
\hline 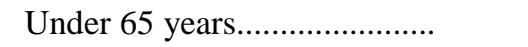 & 11,161 & 11,161 & & & & & & & & \\
\hline 65 years and over.................... & 10,289 & 10,289 & & & & & & & & \\
\hline Two people................................. & 13,991 & & & & & & & & & \\
\hline Householder under 65 years............ & 14,439 & 14,366 & 14,787 & & & & & & & \\
\hline Householder 65 years and over...... & 12,982 & 12,968 & 14,731 & & & & & & & \\
\hline Three people............................ & 17,098 & 16,781 & 17,268 & 17,285 & & & & & & \\
\hline Four people.............................. & 21,954 & 22,128 & 22,490 & 21,756 & 21,832 & & & & & \\
\hline Five people.......................... & 25,991 & 26,686 & 27,074 & 26,245 & 25,603 & 25,211 & & & & \\
\hline Six people............................ & 29,405 & 30,693 & 30,815 & 30,180 & 29,571 & 28,666 & 28,130 & & & \\
\hline Seven people............................ & 33,372 & 35,316 & 35,537 & 34,777 & 34,247 & 33,260 & 32,108 & 30,845 & & \\
\hline Eight people.............................. & 37,252 & 39,498 & 39,847 & 39,130 & 38,501 & 37,610 & 36,478 & 35,300 & 35,000 & \\
\hline Nine people or more.................... & 44,366 & 47,514 & 47,744 & 47,109 & 46,576 & 45,701 & 44,497 & 43,408 & 43,138 & 41,476 \\
\hline
\end{tabular}

Note: The poverty thresholds are updated each year using the change in the average annual Consumer Price Index for All Urban Consumers (CPI-U). Since the average annual CPI-U for 2009 was lower than the average annual CPI-U for 2008, poverty thresholds for 2009 are slightly lower than the corresponding thresholds for 2008 . 
Table B-3. Example of HUD very-low income cutoff by MSA and county in NYS for 2009

\begin{tabular}{|c|c|c|c|c|c|c|c|c|c|}
\hline \multirow[b]{2}{*}{ Name } & \multirow{2}{*}{$\begin{array}{l}2009 \text { median } \\
\text { family income }\end{array}$} & \multicolumn{8}{|c|}{ Number of persons } \\
\hline & & 1 & 2 & 3 & 4 & 5 & 6 & 7 & 8 \\
\hline Albany-Schenectady-Troy, NY MSA & 74,100 & 25,950 & 29,650 & 33,350 & 37,050 & 40,000 & 43,000 & 45,950 & 48,900 \\
\hline Binghamton, NY MSA & 58,600 & 20,500 & 23,450 & 26,350 & 29,300 & 31,650 & 34,000 & 36,350 & 38,700 \\
\hline Buffalo-Niagara Falls, NY MSA & 63,500 & 22,250 & 25,400 & 28,600 & 31,750 & 34,300 & 36,850 & 39,350 & 41,900 \\
\hline Glens Falls, NY MSA & 59,400 & 20,800 & 23,750 & 26,750 & 29,700 & 32,100 & 34,450 & 36,850 & 39,200 \\
\hline Ithaca, NY MSA & 71,300 & 25,150 & 28,700 & 32,300 & 35,900 & 38,750 & 41,650 & 44,500 & 47,400 \\
\hline Kingston, NY MSA & 69,700 & 24,400 & 27,900 & 31,350 & 34,850 & 37,650 & 40,450 & 43,200 & 46,000 \\
\hline Poughkeepsie-Newburgh-Middletown, NY MSA & 81,800 & 28,650 & 32,700 & 36,800 & 40,900 & 44,150 & 47,450 & 50,700 & 54,000 \\
\hline Rochester, NY MSA & 66,500 & 23,300 & 26,600 & 29,950 & 33,250 & 35,900 & 38,550 & 41,250 & 43,900 \\
\hline Syracuse, NY MSA & 63,700 & 22,300 & 25,500 & 28,650 & 31,850 & 34,400 & 36,950 & 39,500 & 42,050 \\
\hline Utica-Rome, NY MSA & 55,800 & 19,550 & 22,300 & 25,100 & 27,900 & 30,150 & 32,350 & 34,600 & 36,850 \\
\hline Nassau-Suffolk, NY HUD Metro FMR Area & 101,800 & 35,650 & 40,700 & 45,800 & 50,900 & 54,950 & 59,050 & 63,100 & 67,200 \\
\hline New York, NY HUD Metro FMR Area & 61,600 & 26,900 & 30,700 & 34,550 & 38,400 & 41,450 & 44,550 & 47,600 & 50,700 \\
\hline Rockland County, NY HUD Metro FMR Area & 102,000 & 35,700 & 40,800 & 45,900 & 51,000 & 55,100 & 59,150 & 63,250 & 67,300 \\
\hline $\begin{array}{l}\text { Westchester County, NY Statutory Exception } \\
\text { Area }\end{array}$ & 105,300 & 36,850 & 42,100 & 47,400 & 52,650 & 56,850 & 61,050 & 65,300 & 69,500 \\
\hline Allegany County, NY & 50,700 & 19,200 & 21,950 & 24,700 & 27,450 & 29,650 & $\mathbf{3 1 , 8 5 0}$ & $\mathbf{3 4 , 0 5 0}$ & 36,250 \\
\hline Cattaraugus County, NY & 51,000 & 19,200 & 21,950 & 24,700 & 27,450 & 29,650 & 31,850 & 34,050 & 36,250 \\
\hline Cayuga County, NY & 58,900 & 20,600 & 23,550 & 26,500 & 29,450 & 31,800 & 34,150 & 36,500 & 38,850 \\
\hline Chautauqua County, NY & 51,900 & 19,200 & 21,950 & 24,700 & 27,450 & 29,650 & 31,850 & 34,050 & 36,250 \\
\hline Chenango County, NY & 53,700 & 19,200 & 21,950 & 24,700 & 27,450 & 29,650 & 31,850 & 34,050 & 36,250 \\
\hline Clinton County, NY & 60,900 & 21,300 & 24,350 & 27,400 & 30,450 & 32,900 & 35,300 & 37,750 & 40,200 \\
\hline Columbia County, NY & 65,400 & 22,900 & 26,150 & 29,450 & 32,700 & 35,300 & 37,950 & 40,550 & 43,150 \\
\hline Cortland County, NY & 56,800 & 19,900 & 22,700 & 25,550 & 28,400 & 30,650 & 32,950 & 35,200 & 37,500 \\
\hline Delaware County, NY & 51,700 & 19,200 & 21,950 & 24,700 & 27,450 & 29,650 & 31,850 & 34,050 & 36,250 \\
\hline
\end{tabular}

Data source: Information extracted from HUD published 2009 data for State of New York..

Note: Highlighted in green is an area with the highest values of HUD very-low income limits; while yellow shows the one with the lowest very-low income limits. 


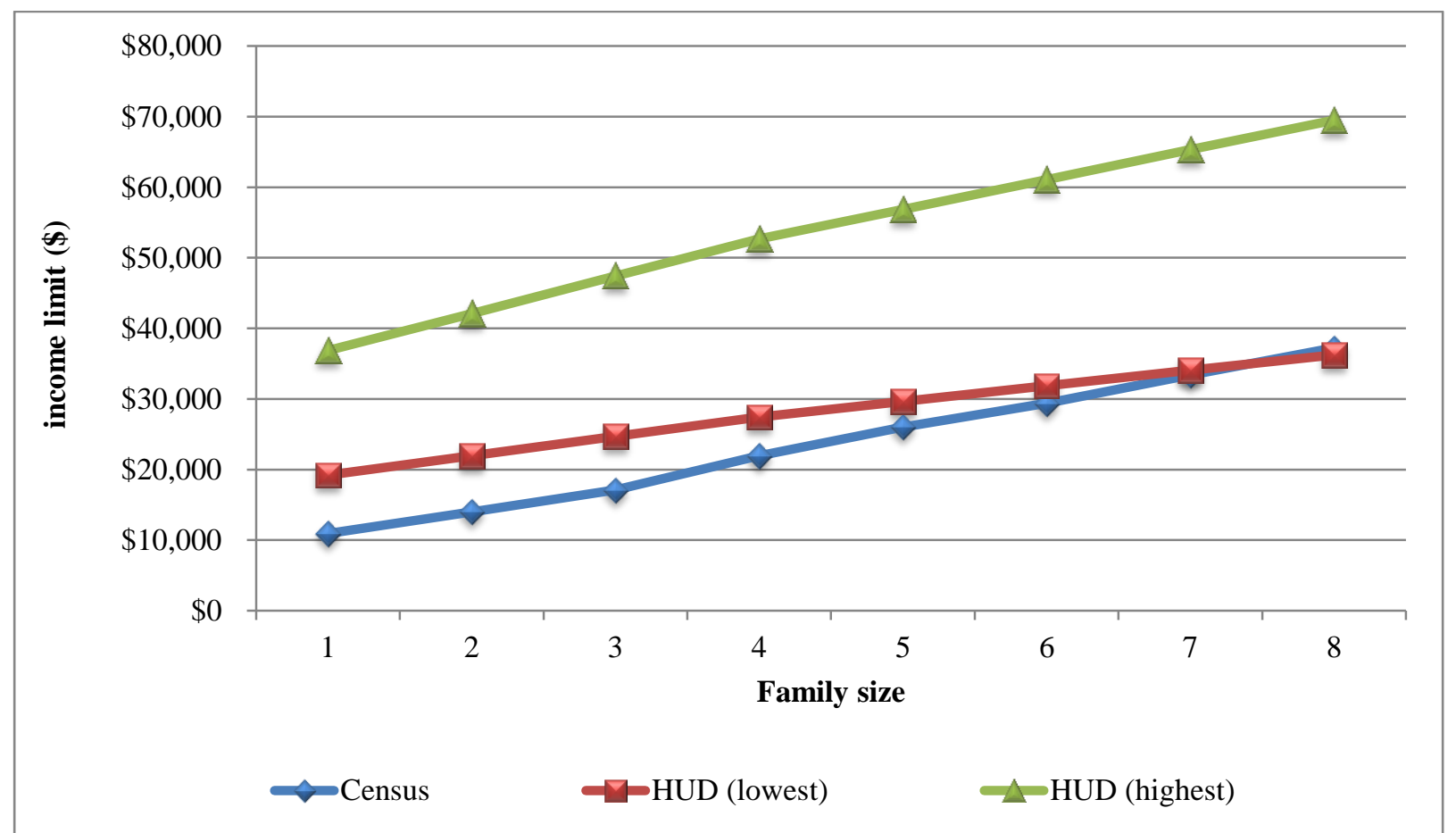

Figure B-1. Comparison of Census national poverty thresholds and HUD very-low income limits for areas in NYS (2009) 
Table B-4A. Persons 5+ and households by HUD low income and very low income status, 2009 NHTS

\begin{tabular}{|c|c|c|c|c|c|c|c|c|c|c|c|c|}
\hline & Manhattan & $\begin{array}{l}\text { Rest of } \\
\text { NYC }\end{array}$ & $\begin{array}{c}\text { New York } \\
\text { City }\end{array}$ & $\begin{array}{c}\text { Other } \\
\text { Urban } \\
\text { (Excludin } \\
\text { g NYC) }\end{array}$ & $\begin{array}{l}\text { Nassau, } \\
\text { Suffolk }\end{array}$ & $\begin{array}{c}\text { Putnam, } \\
\text { Rockland, } \\
\text { Westcheste } \\
\text { r }\end{array}$ & $\begin{array}{l}\text { NY Metro } \\
\text { Total }\end{array}$ & 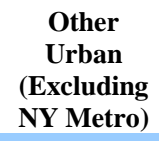 & ALL Urban & $\begin{array}{l}\text { Non- } \\
\text { Urban } \\
\text { Areas }\end{array}$ & Statewide & Rest of US \\
\hline Persons 5+ & $1,534,921$ & $6,253,053$ & $7,787,974$ & $8,781,608$ & $2,698,459$ & $1,265,119$ & $11,751,552$ & 4,818,031 & $16,569,583$ & $1,712,219$ & $18,281,802$ & $264,772,070$ \\
\hline $\begin{array}{l}\text { Very Low } \\
\text { Income }\end{array}$ & 360,337 & $2,548,724$ & $2,909,061$ & $1,939,611$ & 523,147 & 333,477 & $3,765,685$ & $1,082,988$ & $4,848,673$ & 392,321 & $5,240,993$ & $66,417,900$ \\
\hline $\begin{array}{l}\text { Low } \\
\text { Income* }\end{array}$ & 539,798 & $3,483,486$ & $4,023,284$ & $3,305,909$ & 919,157 & 464,877 & $5,407,318$ & $1,921,875$ & $7,329,193$ & 739,568 & $8,068,761$ & $108,763,683$ \\
\hline $\begin{array}{l}\text { Not Low } \\
\text { Income }\end{array}$ & 909,067 & $2,350,647$ & $3,259,715$ & $4,882,397$ & $1,588,821$ & 715,267 & $5,563,803$ & $2,578,309$ & $8,142,112$ & 898,183 & $9,040,295$ & $142,436,942$ \\
\hline Unreported & 86,056 & 418,919 & 504,975 & 593,303 & 190,481 & 84,975 & 780,431 & 317,847 & $1,098,278$ & 74,468 & $1,172,746$ & $13,571,446$ \\
\hline \multicolumn{13}{|l|}{$\begin{array}{l}\text { \% Persons } \\
5+\end{array}$} \\
\hline $\begin{array}{l}\text { Very Low } \\
\text { Income }\end{array}$ & $23.48 \%$ & $40.76 \%$ & $37.35 \%$ & $22.09 \%$ & $19.39 \%$ & $26.36 \%$ & $32.04 \%$ & $22.48 \%$ & $29.26 \%$ & $22.91 \%$ & $28.67 \%$ & $25.08 \%$ \\
\hline $\begin{array}{l}\text { Low } \\
\text { Income* }\end{array}$ & $35.17 \%$ & $55.71 \%$ & $51.66 \%$ & $37.65 \%$ & $34.06 \%$ & $36.75 \%$ & $46.01 \%$ & $39.89 \%$ & $44.23 \%$ & $43.19 \%$ & $44.14 \%$ & $41.08 \%$ \\
\hline $\begin{array}{l}\text { Not Low } \\
\text { Income }\end{array}$ & $59.23 \%$ & $37.59 \%$ & $41.86 \%$ & $55.60 \%$ & $58.88 \%$ & $56.54 \%$ & $47.35 \%$ & $53.51 \%$ & $49.14 \%$ & $52.46 \%$ & $49.45 \%$ & $53.80 \%$ \\
\hline Unreported & $5.61 \%$ & $6.70 \%$ & $6.48 \%$ & $6.76 \%$ & $7.06 \%$ & $6.72 \%$ & $6.64 \%$ & $6.60 \%$ & $6.63 \%$ & $4.35 \%$ & $6.41 \%$ & $5.13 \%$ \\
\hline HHs & 749,335 & $2,305,938$ & $3,055,273$ & $3,380,154$ & 911,037 & 469,399 & $4,435,710$ & $1,999,718$ & $6,435,427$ & 702,055 & $7,137,482$ & $105,963,848$ \\
\hline $\begin{array}{l}\text { Very Low } \\
\text { Income }\end{array}$ & 159,472 & 878,592 & $1,038,064$ & 856,329 & 194,483 & 140,423 & $1,372,970$ & 521,423 & $1,894,394$ & 195,730 & $2,090,123$ & $28,789,669$ \\
\hline $\begin{array}{l}\text { Low } \\
\text { Income* }\end{array}$ & 250,693 & $1,274,661$ & $1,525,354$ & $1,415,361$ & 331,248 & 199,849 & $2,056,451$ & 884,264 & $2,940,715$ & 327,586 & $3,268,301$ & $46,166,790$ \\
\hline $\begin{array}{l}\text { Not Low } \\
\text { Income }\end{array}$ & 421,244 & 822,561 & $1,243,805$ & $1,663,837$ & 488,853 & 228,936 & $1,961,593$ & 946,049 & $2,907,642$ & 336,804 & $3,244,445$ & $52,528,073$ \\
\hline Unreported & 77,398 & 208,717 & 286,115 & 300,957 & 90,937 & 40,615 & 417,666 & 169,405 & 587,071 & 37,665 & 624,736 & $7,268,985$ \\
\hline \multicolumn{13}{|l|}{$\%$ HHs } \\
\hline $\begin{array}{l}\text { Very Low } \\
\text { Income }\end{array}$ & $21.28 \%$ & $38.10 \%$ & $33.98 \%$ & $25.33 \%$ & $21.35 \%$ & $29.92 \%$ & $30.95 \%$ & $26.07 \%$ & $29.44 \%$ & $27.88 \%$ & $29.28 \%$ & $27.17 \%$ \\
\hline $\begin{array}{l}\text { Low } \\
\text { Income* }\end{array}$ & $33.46 \%$ & $55.28 \%$ & $49.93 \%$ & $41.87 \%$ & $36.36 \%$ & $42.58 \%$ & $46.36 \%$ & $44.22 \%$ & $45.70 \%$ & $46.66 \%$ & $45.79 \%$ & $43.57 \%$ \\
\hline $\begin{array}{l}\text { Not Low } \\
\text { Income }\end{array}$ & $56.22 \%$ & $35.67 \%$ & $40.71 \%$ & $49.22 \%$ & $53.66 \%$ & $48.77 \%$ & $44.22 \%$ & $47.31 \%$ & $45.18 \%$ & $47.97 \%$ & $45.46 \%$ & $49.57 \%$ \\
\hline Unreported & $10.33 \%$ & $9.05 \%$ & $9.36 \%$ & $8.90 \%$ & $9.98 \%$ & $8.65 \%$ & $9.42 \%$ & $8.47 \%$ & $9.12 \%$ & $5.36 \%$ & $8.75 \%$ & $6.86 \%$ \\
\hline
\end{tabular}


Table B-4B. Persons 5+ and households by HUD low income and very low income status, 2001 NHTS

\begin{tabular}{|c|c|c|c|c|c|c|c|c|c|c|c|c|}
\hline & Manhattan & $\begin{array}{l}\text { Rest of } \\
\text { NYC }\end{array}$ & $\begin{array}{c}\text { New York } \\
\text { City }\end{array}$ & $\begin{array}{c}\text { Other } \\
\text { Urban } \\
\text { (Excluding } \\
\text { NYC) }\end{array}$ & $\begin{array}{l}\text { Nassau, } \\
\text { Suffolk }\end{array}$ & $\begin{array}{c}\text { Putnam, } \\
\text { Rockland, } \\
\text { Westchester }\end{array}$ & $\begin{array}{c}\text { NY Metro } \\
\text { Total }\end{array}$ & $\begin{array}{c}\text { Other } \\
\text { Urban } \\
\text { (Excluding } \\
\text { NY Metro) }\end{array}$ & ALL Urban & $\begin{array}{l}\text { Non- } \\
\text { Urban } \\
\text { Areas }\end{array}$ & Statewide & Rest of US \\
\hline Persons 5+ & $1,428,557$ & $6,010,400$ & $7,438,957$ & $7,909,564$ & $2,516,956$ & $1,181,859$ & $11,137,773$ & $4,210,748$ & $15,348,521$ & $2,045,872$ & $17,394,393$ & $240,182,520$ \\
\hline $\begin{array}{l}\text { Very Low } \\
\text { Income }\end{array}$ & 335,804 & $2,190,996$ & $2,526,800$ & $1,340,959$ & 346,927 & 240,798 & $3,114,525$ & 753,235 & $3,867,759$ & 375,350 & $4,243,110$ & $48,410,575$ \\
\hline $\begin{array}{l}\text { Low } \\
\text { Income* }\end{array}$ & 525,093 & $3,319,118$ & $3,844,211$ & $2,513,912$ & 740,423 & 330,518 & $4,915,152$ & $1,442,970$ & $6,358,123$ & 782,674 & $7,140,797$ & $91,003,447$ \\
\hline $\begin{array}{l}\text { Not Low } \\
\text { Income }\end{array}$ & 735,057 & $2,225,389$ & $2,960,446$ & $4,768,017$ & $1,547,374$ & 750,482 & $5,258,303$ & $2,470,161$ & $7,728,464$ & $1,153,223$ & $8,881,687$ & $133,399,071$ \\
\hline Unreported & 168,407 & 465,893 & 634,301 & 627,634 & 229,158 & 100,858 & 964,317 & 297,617 & $1,261,935$ & 109,975 & $1,371,909$ & $15,780,002$ \\
\hline \multicolumn{13}{|l|}{$\begin{array}{l}\text { \% Persons } \\
5+\end{array}$} \\
\hline $\begin{array}{l}\text { Very Low } \\
\text { Income }\end{array}$ & $23.51 \%$ & $36.45 \%$ & $33.97 \%$ & $16.95 \%$ & $13.78 \%$ & $20.37 \%$ & $27.96 \%$ & $17.89 \%$ & $25.20 \%$ & $18.35 \%$ & $24.39 \%$ & $20.16 \%$ \\
\hline $\begin{array}{l}\text { Low } \\
\text { Income* }\end{array}$ & $36.76 \%$ & $55.22 \%$ & $51.68 \%$ & $31.78 \%$ & $29.42 \%$ & $27.97 \%$ & $44.13 \%$ & $34.27 \%$ & $41.42 \%$ & $38.26 \%$ & $41.05 \%$ & $37.89 \%$ \\
\hline $\begin{array}{l}\text { Not Low } \\
\text { Income }\end{array}$ & $51.45 \%$ & $37.03 \%$ & $39.80 \%$ & $60.28 \%$ & $61.48 \%$ & $63.50 \%$ & $47.21 \%$ & $58.66 \%$ & $50.35 \%$ & $56.37 \%$ & $51.06 \%$ & $55.54 \%$ \\
\hline Unreported & $11.79 \%$ & $7.75 \%$ & $8.53 \%$ & $7.94 \%$ & $9.10 \%$ & $8.53 \%$ & $8.66 \%$ & $7.07 \%$ & $8.22 \%$ & $5.38 \%$ & $7.89 \%$ & $6.57 \%$ \\
\hline HHs & 751,869 & $2,323,819$ & $3,075,688$ & $3,241,542$ & 933,098 & 470,801 & 4,479,587 & $1,837,643$ & $6,317,230$ & 865,978 & $7,183,208$ & $100,182,138$ \\
\hline $\begin{array}{l}\text { Very Low } \\
\text { Income }\end{array}$ & 163,749 & 824,876 & 988,626 & 676,180 & 164,417 & 109,146 & $1,262,189$ & 402,617 & $1,664,806$ & 190,328 & $1,855,134$ & $23,136,196$ \\
\hline $\begin{array}{l}\text { Low } \\
\text { Income* }\end{array}$ & 244,927 & $1,250,526$ & $1,495,453$ & $1,161,230$ & 296,740 & 148,228 & $1,940,420$ & 716,263 & $2,656,683$ & 350,553 & $3,007,236$ & $40,710,234$ \\
\hline $\begin{array}{l}\text { Not Low } \\
\text { Income }\end{array}$ & 406,600 & 808,084 & $1,214,684$ & $1,774,180$ & 536,004 & 271,116 & $2,021,803$ & 967,061 & $2,988,864$ & 448,733 & $3,437,597$ & $51,373,810$ \\
\hline Unreported & 100,342 & 265,210 & 365,551 & 306,131 & 100,355 & 51,457 & 517,363 & 154,319 & 671,682 & 66,692 & 738,375 & $8,098,094$ \\
\hline \multicolumn{13}{|l|}{ \% HHs } \\
\hline $\begin{array}{l}\text { Very Low } \\
\text { Income }\end{array}$ & $21.78 \%$ & $35.50 \%$ & $32.14 \%$ & $20.86 \%$ & $17.62 \%$ & $23.18 \%$ & $28.18 \%$ & $21.91 \%$ & $26.35 \%$ & $21.98 \%$ & $25.83 \%$ & $23.09 \%$ \\
\hline $\begin{array}{l}\text { Low } \\
\text { Income* }\end{array}$ & $32.58 \%$ & $53.81 \%$ & $48.62 \%$ & $35.82 \%$ & $31.80 \%$ & $31.48 \%$ & $43.32 \%$ & $38.98 \%$ & $42.05 \%$ & $40.48 \%$ & $41.86 \%$ & $40.64 \%$ \\
\hline $\begin{array}{l}\text { Not Low } \\
\text { Income }\end{array}$ & $54.08 \%$ & $34.77 \%$ & $39.49 \%$ & $54.73 \%$ & $57.44 \%$ & $57.59 \%$ & $45.13 \%$ & $52.63 \%$ & $47.31 \%$ & $51.82 \%$ & $47.86 \%$ & $51.28 \%$ \\
\hline Unreported & $13.35 \%$ & $11.41 \%$ & $11.89 \%$ & $9.44 \%$ & $10.75 \%$ & $10.93 \%$ & $11.55 \%$ & $8.40 \%$ & $10.63 \%$ & $7.70 \%$ & $10.28 \%$ & $8.08 \%$ \\
\hline
\end{tabular}


Table B-4C. Persons 5+ and households by HUD low income and very low income status, 1995 NPTS

\begin{tabular}{|c|c|c|c|c|c|c|c|c|c|c|c|c|}
\hline & Manhattan & $\begin{array}{l}\text { Rest of } \\
\text { NYC }\end{array}$ & $\begin{array}{c}\text { New York } \\
\text { City }\end{array}$ & $\begin{array}{c}\text { Other } \\
\text { Urban } \\
\text { (Excluding } \\
\text { NYC) }\end{array}$ & $\begin{array}{l}\text { Nassau, } \\
\text { Suffolk }\end{array}$ & $\begin{array}{l}\text { Putnam, } \\
\text { Rockland, } \\
\text { Westchester }\end{array}$ & $\begin{array}{l}\text { NY Metro } \\
\text { Total }\end{array}$ & $\begin{array}{c}\text { Other } \\
\text { Urban } \\
\text { (Excluding } \\
\text { NY Metro) }\end{array}$ & ALL Urban & $\begin{array}{l}\text { Non- } \\
\text { Urban } \\
\text { Areas }\end{array}$ & Statewide & Rest of US \\
\hline Persons 5+ & $1,432,998$ & $5,358,983$ & $6,791,981$ & $7,917,005$ & $2,467,001$ & $1,166,000$ & $10,424,982$ & $4,284,004$ & $14,708,986$ & $2,098,002$ & $16,806,988$ & $224,868,012$ \\
\hline $\begin{array}{l}\text { Very Low } \\
\text { Income }\end{array}$ & 353,182 & $1,617,951$ & $1,971,133$ & $1,059,801$ & 334,087 & 137,695 & $2,442,915$ & 588,019 & $3,030,934$ & 360,898 & $3,391,832$ & $35,499,832$ \\
\hline $\begin{array}{l}\text { Low } \\
\text { Income* }\end{array}$ & 544,174 & $2,566,281$ & $3,110,455$ & $2,022,101$ & 552,258 & 218,984 & $3,881,697$ & $1,250,859$ & $5,132,556$ & 730,573 & $5,863,129$ & $70,270,507$ \\
\hline $\begin{array}{l}\text { Not Low } \\
\text { Income }\end{array}$ & 602,059 & $1,772,576$ & $2,374,636$ & $4,359,989$ & $1,392,628$ & 661,662 & $4,428,926$ & $2,305,699$ & $6,734,625$ & $1,071,980$ & $7,806,605$ & $117,487,262$ \\
\hline Unreported & 286,765 & $1,020,126$ & $1,306,891$ & $1,534,915$ & 522,115 & 285,355 & $2,114,360$ & 727,445 & $2,841,805$ & 295,449 & $3,137,254$ & $37,110,242$ \\
\hline \multicolumn{13}{|l|}{$\begin{array}{l}\text { \% Persons } \\
5+\end{array}$} \\
\hline $\begin{array}{l}\text { Very Low } \\
\text { Income }\end{array}$ & $24.65 \%$ & $30.19 \%$ & $29.02 \%$ & $13.39 \%$ & $13.54 \%$ & $11.81 \%$ & $23.43 \%$ & $13.73 \%$ & $20.61 \%$ & $17.20 \%$ & $20.18 \%$ & $15.79 \%$ \\
\hline $\begin{array}{l}\text { Low } \\
\text { Income* }\end{array}$ & $37.97 \%$ & $47.89 \%$ & $45.80 \%$ & $25.54 \%$ & $22.39 \%$ & $18.78 \%$ & $37.23 \%$ & $29.20 \%$ & $34.89 \%$ & $34.82 \%$ & $34.89 \%$ & $31.25 \%$ \\
\hline $\begin{array}{l}\text { Not Low } \\
\text { Income }\end{array}$ & $42.01 \%$ & $33.08 \%$ & $34.96 \%$ & $55.07 \%$ & $56.45 \%$ & $56.75 \%$ & $42.48 \%$ & $53.82 \%$ & $45.79 \%$ & $51.10 \%$ & $46.45 \%$ & $52.25 \%$ \\
\hline Unreported & $20.01 \%$ & $19.04 \%$ & $19.24 \%$ & $19.39 \%$ & $21.16 \%$ & $24.47 \%$ & $20.28 \%$ & $16.98 \%$ & $19.32 \%$ & $14.08 \%$ & $18.67 \%$ & $16.50 \%$ \\
\hline HHs & 667,703 & $1,884,641$ & $2,552,344$ & $2,823,951$ & 794,304 & 407,602 & $3,754,251$ & $1,622,044$ & $5,376,295$ & 755,700 & $6,131,995$ & $92,858,005$ \\
\hline $\begin{array}{l}\text { Very Low } \\
\text { Income }\end{array}$ & 132,355 & 524,603 & 656,958 & 439,638 & 120,885 & 45,895 & 823,737 & 272,859 & $1,096,596$ & 145,866 & $1,242,461$ & $16,270,896$ \\
\hline $\begin{array}{l}\text { Low } \\
\text { Income* }\end{array}$ & 220,336 & 844,873 & $1,065,209$ & 798,574 & 193,593 & 77,667 & $1,336,469$ & 527,314 & $1,863,783$ & 272,366 & $2,136,149$ & $30,935,881$ \\
\hline $\begin{array}{l}\text { Not Low } \\
\text { Income }\end{array}$ & 303,393 & 660,014 & 963,407 & $1,469,088$ & 426,746 & 228,931 & $1,619,085$ & 813,410 & $2,432,495$ & 367,637 & $2,800,132$ & $46,568,019$ \\
\hline Unreported & 143,974 & 379,754 & 523,728 & 556,289 & 173,965 & 101,004 & 798,697 & 281,320 & $1,080,017$ & 115,697 & $1,195,714$ & $15,354,105$ \\
\hline \multicolumn{13}{|l|}{$\% \mathrm{HHs}$} \\
\hline $\begin{array}{l}\text { Very Low } \\
\text { Income }\end{array}$ & $19.82 \%$ & $27.84 \%$ & $25.74 \%$ & $15.57 \%$ & $15.22 \%$ & $11.26 \%$ & $21.94 \%$ & $16.82 \%$ & $20.40 \%$ & $19.30 \%$ & $20.26 \%$ & $17.52 \%$ \\
\hline $\begin{array}{l}\text { Low } \\
\text { Income* }\end{array}$ & $33.00 \%$ & $44.83 \%$ & $41.73 \%$ & $28.28 \%$ & $24.37 \%$ & $19.05 \%$ & $35.60 \%$ & $32.51 \%$ & $34.67 \%$ & $36.04 \%$ & $34.84 \%$ & $33.32 \%$ \\
\hline $\begin{array}{l}\text { Not Low } \\
\text { Income }\end{array}$ & $45.44 \%$ & $35.02 \%$ & $37.75 \%$ & $52.02 \%$ & $53.73 \%$ & $56.17 \%$ & $43.13 \%$ & $50.15 \%$ & $45.24 \%$ & $48.65 \%$ & $45.66 \%$ & $50.15 \%$ \\
\hline Unreported & $21.56 \%$ & $20.15 \%$ & $20.52 \%$ & $19.70 \%$ & $21.90 \%$ & $24.78 \%$ & $21.27 \%$ & $17.34 \%$ & $20.09 \%$ & $15.31 \%$ & $19.50 \%$ & $16.54 \%$ \\
\hline
\end{tabular}


Table B-5. Daily person trips per person by region of residency

\begin{tabular}{|c|c|c|c|c|c|c|c|c|}
\hline HH Income Group & NHTS year & NYC & $\begin{array}{c}\text { Rest of } \\
\text { NYMTC }\end{array}$ & $\begin{array}{c}\text { Other Urban, Dens } \\
2,000+\text { per square } \\
\text { mile }\end{array}$ & \begin{tabular}{|c|} 
Other Urban, Dens \\
$500-1,999$ per \\
square mile
\end{tabular} & $\begin{array}{c}\text { Other Urban, } \\
\text { Dens <500 per } \\
\text { square mile }\end{array}$ & $\begin{array}{l}\text { NYS Non- } \\
\text { Urban Areas }\end{array}$ & Rest of U.S. \\
\hline \multirow{3}{*}{ Very-low income } & 1995 & 3.3 & 3.6 & 3.5 & 4.0 & 3.7 & 3.4 & 3.8 \\
\hline & 2001 & 3.0 & 3.5 & 3.5 & 3.8 & 3.3 & 3.6 & 3.5 \\
\hline & 2009 & 3.0 & 3.7 & 3.1 & 3.1 & 3.1 & 3.0 & 3.3 \\
\hline \multirow{3}{*}{ Other income } & 1995 & 3.9 & 4.2 & 4.5 & 4.3 & 4.1 & 4.2 & 4.6 \\
\hline & 2001 & 3.8 & 3.9 & 4.3 & 4.3 & 3.9 & 4.1 & 4.4 \\
\hline & 2009 & 3.9 & 4.1 & 3.8 & 4.0 & 4.2 & 3.7 & 4.0 \\
\hline
\end{tabular}

Table B-6. Daily vehicle trips per driver by region of residency

\begin{tabular}{|c|c|c|c|c|c|c|c|c|}
\hline HH Income Group & NHTS year & NYC & $\begin{array}{c}\text { Rest of } \\
\text { NYMTC }\end{array}$ & $\begin{array}{c}\text { Other Urban, Dens } \\
\begin{array}{c}2,000+\text { per square } \\
\text { mile }\end{array}\end{array}$ & \begin{tabular}{|c} 
Other Urban, Dens \\
500-1,999 per \\
square mile \\
\end{tabular} & $\begin{array}{c}\text { Other Urban, } \\
\text { Dens }<500 \text { per } \\
\text { square mile }\end{array}$ & \begin{tabular}{|c|} 
NYS Non- \\
Urban Areas \\
\end{tabular} & Rest of U.S. \\
\hline \multirow{3}{*}{ Very-low income } & 1995 & 1.2 & 3.1 & 3.0 & 3.2 & 3.0 & 3.0 & 3.1 \\
\hline & 2001 & 1.2 & 2.9 & 2.8 & 3.4 & 2.6 & 2.7 & 2.9 \\
\hline & 2009 & 0.7 & 2.7 & 2.5 & 2.5 & 2.5 & 2.5 & 2.6 \\
\hline \multirow{3}{*}{ Other income } & 1995 & 1.8 & 3.4 & 3.8 & 3.6 & 3.6 & 3.6 & 3.8 \\
\hline & 2001 & 1.7 & 3.2 & 3.6 & 3.6 & 3.3 & 3.3 & 3.6 \\
\hline & 2009 & 1.4 & 3.2 & 3.1 & 3.3 & 3.3 & 3.1 & 3.2 \\
\hline
\end{tabular}

Table B-7. Daily vehicle trip length by region of residency

\begin{tabular}{|c|c|c|c|c|c|c|c|c|}
\hline HH Income Group & NHTS year & NYC & $\begin{array}{c}\text { Rest of } \\
\text { NYMTC }\end{array}$ & $\begin{array}{c}\text { Other Urban, Dens } \\
2,000+\text { per square } \\
\text { mile }\end{array}$ & \begin{tabular}{|c|} 
Other Urban, Dens \\
500-1,999 per \\
square mile
\end{tabular} & $\begin{array}{c}\text { Other Urban, } \\
\text { Dens }<500 \text { per } \\
\text { square mile }\end{array}$ & $\begin{array}{c}\text { NYS Non- } \\
\text { Urban Areas }\end{array}$ & Rest of U.S. \\
\hline \multirow{3}{*}{ Very-low income } & 1995 & 6.6 & 6.5 & 6.4 & 7.3 & 8.1 & 9.5 & 7.5 \\
\hline & 2001 & 6.7 & 8.1 & 5.9 & 6.0 & 9.5 & 10.0 & 9.1 \\
\hline & 2009 & 5.8 & 6.4 & 9.3 & 6.7 & 5.9 & 9.9 & 8.7 \\
\hline \multirow{3}{*}{ Other income } & 1995 & 9.1 & 8.7 & 6.9 & 8.9 & 10.3 & 10.7 & 9.4 \\
\hline & 2001 & 8.2 & 9.2 & 8.0 & 8.8 & 11.1 & 10.7 & 10.1 \\
\hline & 2009 & 8.0 & 8.5 & 11.3 & 9.8 & 6.9 & 10.9 & 10.0 \\
\hline
\end{tabular}


Table B-8. Standard errors for commute statistics by mode, income status, and population density in 2009

\begin{tabular}{|c|c|c|c|c|c|c|c|c|c|c|c|c|}
\hline \multirow{3}{*}{$\begin{array}{l}\text { Mode of commute } \\
\text { trips }\end{array}$} & \multicolumn{12}{|c|}{ Population Density (Population per square mile) } \\
\hline & \multicolumn{2}{|c|}{$<500$} & \multicolumn{2}{|c|}{$500-1999$} & \multicolumn{2}{|c|}{$2000-2999$} & \multicolumn{2}{|c|}{$4000-9999$} & \multicolumn{2}{|c|}{$10,000-24,999$} & \multicolumn{2}{|c|}{$25,000+$} \\
\hline & NYS & U.S & NYS & U.S & NYS & U.S & NYS & U.S & NYS & U.S & NYS & $\mathbf{U . S}$ \\
\hline \multicolumn{13}{|c|}{ Average Commute Length (miles) } \\
\hline \multicolumn{13}{|c|}{ Very Low Income Persons } \\
\hline Private vehicle & 1.25 & 0.75 & 1.59 & 1.17 & 0.80 & 0.54 & 1.78 & 0.75 & 1.35 & 1.08 & 10.03 & 2.94 \\
\hline Public transit & 1.95 & 2.34 & 4.06 & 5.81 & 1.17 & 1.93 & 1.74 & 1.28 & 2.12 & 1.61 & 2.22 & 3.58 \\
\hline Other & 3.81 & 1.89 & 3.75 & 4.86 & 4.05 & 0.42 & 1.71 & 1.10 & 17.69 & 1.28 & 3.89 & 3.79 \\
\hline Walk & 0.06 & 0.12 & 1.02 & 2.92 & 0.19 & 0.17 & 1.12 & 0.21 & 0.17 & 0.25 & 0.12 & 0.07 \\
\hline \multicolumn{13}{|c|}{ Not Very Low Income Persons } \\
\hline Private vehicle & 0.51 & 0.28 & 0.49 & 0.41 & 0.77 & 0.24 & 0.64 & 0.25 & 0.85 & 0.57 & 1.39 & 0.98 \\
\hline Public transit & 10.33 & 3.74 & 3.80 & 7.32 & 3.30 & 5.43 & 2.26 & 2.10 & 1.84 & 1.21 & 0.67 & 1.08 \\
\hline Other & 70.49 & 36.14 & 6.29 & 25.65 & 0.14 & 7.07 & 1.71 & 2.62 & 18.65 & 8.32 & 0.54 & 1.08 \\
\hline Walk & 0.08 & 0.07 & 0.45 & 0.11 & 0.05 & 0.37 & 0.18 & 0.13 & 0.18 & 0.21 & 0.64 & 0.11 \\
\hline \multicolumn{13}{|c|}{ Commute Travel Time (minutes) } \\
\hline \multicolumn{13}{|c|}{ Very Low Income Persons } \\
\hline Private vehicle & 1.53 & 1.00 & 1.89 & 1.93 & 1.59 & 0.82 & 5.50 & 1.02 & 3.71 & 1.54 & 14.39 & 3.47 \\
\hline Public transit & 13.41 & 10.03 & 6.16 & 26.81 & 6.34 & 11.56 & 7.05 & 4.44 & 2.95 & 6.06 & 2.89 & 4.40 \\
\hline Other & 5.78 & 6.39 & 4.18 & 7.99 & 2.16 & 2.38 & 2.07 & 2.86 & 20.42 & 3.50 & 17.01 & 11.56 \\
\hline Walk & 2.36 & 3.01 & 4.41 & 8.93 & 6.32 & 2.84 & 6.43 & 3.25 & 4.59 & 2.86 & 2.34 & 1.07 \\
\hline \multicolumn{13}{|c|}{ Not Very Low Income Persons } \\
\hline Private vehicle & 0.74 & 0.36 & 0.98 & 0.44 & 1.24 & 0.43 & 1.18 & 0.39 & 1.72 & 1.09 & 2.46 & 2.85 \\
\hline Public transit & 9.68 & 7.92 & 6.01 & 9.30 & 6.53 & 23.79 & 6.01 & 3.97 & 4.77 & 3.41 & 1.97 & 9.76 \\
\hline Other & 11.40 & 6.16 & 13.87 & 5.49 & 4.30 & 8.60 & 6.04 & 3.92 & 11.38 & 5.39 & 2.70 & 3.36 \\
\hline Walk & 1.44 & 1.05 & 1.95 & 10.88 & 3.44 & 3.48 & 3.26 & 1.38 & 3.05 & 1.55 & 2.77 & 1.45 \\
\hline \multicolumn{13}{|c|}{ Average Commute Speed (mph) } \\
\hline \multicolumn{13}{|c|}{ Very Low Income Persons } \\
\hline Private vehicle & 2.17 & 0.97 & 3.59 & 1.45 & 2.01 & 1.01 & 1.47 & 1.29 & 1.47 & 2.08 & 5.87 & 3.35 \\
\hline Public transit & 5.00 & 3.99 & 6.48 & 2.74 & 1.06 & 1.45 & 1.91 & 1.12 & 2.78 & 1.27 & 2.61 & 3.25 \\
\hline Other & 3.95 & 4.07 & 9.15 & 6.08 & 17.51 & 0.52 & 3.80 & 2.56 & 23.46 & 3.19 & 7.60 & 3.15 \\
\hline Walk & 2.49 & 0.81 & 1.74 & 7.20 & 1.11 & 0.76 & 5.89 & 0.47 & 0.64 & 0.96 & 0.71 & 0.21 \\
\hline \multicolumn{13}{|c|}{ Not Very Low Income Persons } \\
\hline Private vehicle & 0.52 & 0.32 & 0.99 & 0.59 & 0.69 & 0.41 & 1.07 & 0.35 & 1.23 & 0.82 & 1.96 & 2.08 \\
\hline Public transit & 7.50 & 3.52 & 1.40 & 4.97 & 2.23 & 1.39 & 1.44 & 1.94 & 1.43 & 1.16 & 0.77 & 1.65 \\
\hline Other & 68.86 & 77.29 & 3.80 & 51.68 & 2.15 & 5.91 & 1.28 & 4.58 & 26.11 & 18.37 & 0.96 & 1.61 \\
\hline Walk & 0.50 & 0.41 & 1.49 & 0.38 & 0.36 & 1.08 & 0.48 & 0.41 & 0.74 & 0.76 & 1.21 & 0.49 \\
\hline
\end{tabular}

Yellow shaded cells are based on small samples. 
OAK RIDGE NATIONAL LABORATORY 
